US Army Corps of Engineers ${ }_{\circledast}$ Engineer Research and Development Center

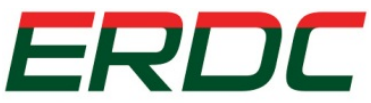

INNOVATIVE SOLUTIONS for a safer, better world

Geospatial Remote Assessment for Ingress Locations (GRAIL)

\title{
Landing-Zone and Drop-Zone Criteria
}

Wendy L. Wieder and Sally A. Shoop

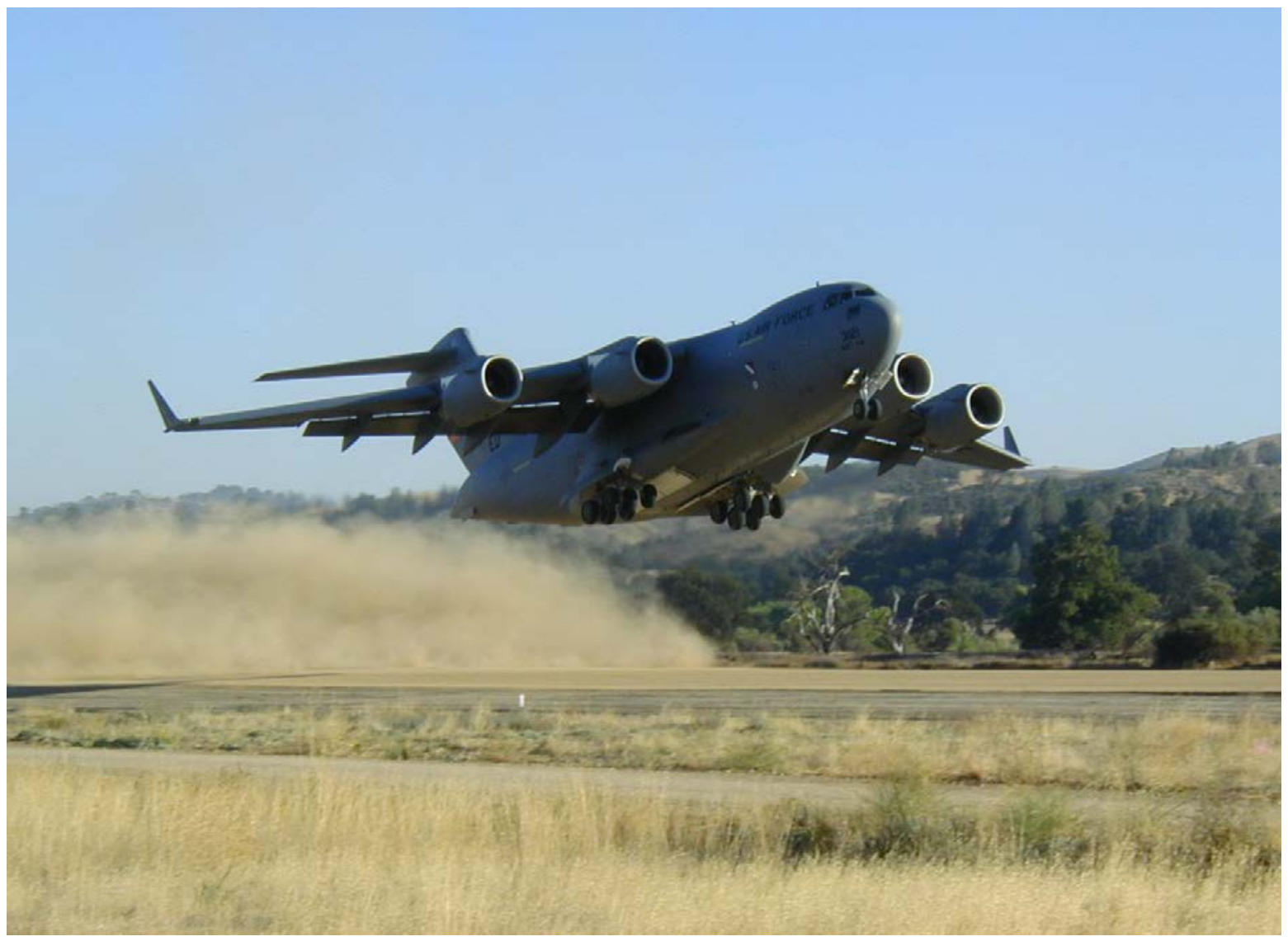


The U.S. Army Engineer Research and Development Center (ERDC) solves the nation's toughest engineering and environmental challenges. ERDC develops innovative solutions in civil and military engineering, geospatial sciences, water resources, and environmental sciences for the Army, the Department of Defense, civilian agencies, and our nation's public good. Find out more at www.erdc.usace.army.mil.

To search for other technical reports published by ERDC, visit the ERDC online library at http://acwc.sdp.sirsi.net/client/default. 


\title{
Landing-Zone and Drop-Zone Criteria
}

\author{
Wendy L. Wieder and Sally A. Shoop \\ U.S. Army Engineer Research and Development Center (ERDC) \\ Cold Regions Research and Engineering Laboratory (CRREL) \\ 72 Lyme Road \\ Hanover, NH 03755-1290
}

Final Report

Approved for public release; distribution is unlimited.

Prepared for Army Terrestrial Environmental Modeling and Intelligence System (ARTEMIS)

U.S. Army Engineer Research and Development Center (ERDC)

Cold Regions Research and Engineering Laboratory (CRREL)

72 Lyme Road

Hanover, NH 03755-1290

Under Work Item 9K3D08 for the Geospatial Remote Assessment for Ingress Locations (GRAIL) Project 


\section{Abstract}

The criteria for landing zones (LZs) and drop zones (DZs), also known as austere entry surfaces, are extensive and varied. They range from very specific guidance on required geometry to more general guidance on required bearing strength of unprepared surfaces, such as soil or ice, and the smoothness of those surfaces. Current practice for siting LZs and DZs includes site surveys by trained personnel, often in hostile environments. Additionally, with the continued advancement of image analysis, it may be possible to identify potential LZ and DZ sites remotely and thus to reduce the need to expose personnel to dangerous conditions. This review intends to summarize existing Federal, Department of Defense, and other criteria for unsurfaced, unimproved LZs and DZs. The purpose of the summary is to consolidate criteria so that the criteria may be considered in the process of developing and refining methods to remotely locate and assess potential LZs and DZs by using satellite imagery. 


\section{Contents}

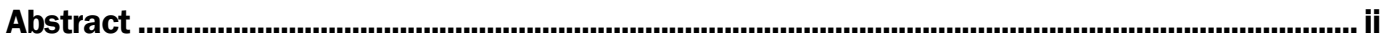

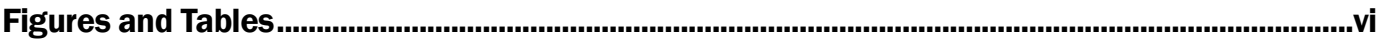

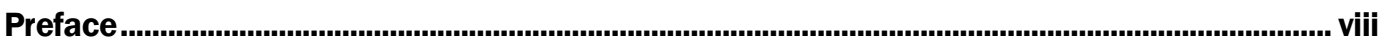

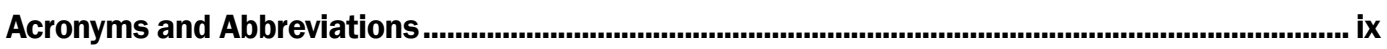

Unit Conversion Factors ..................................................................................................................... xii

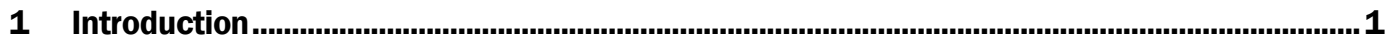

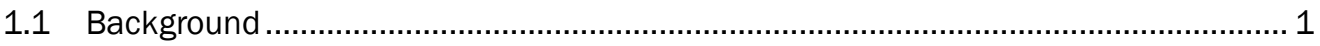

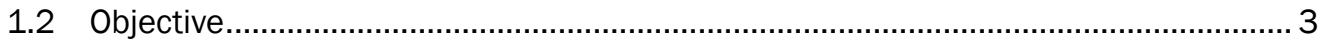

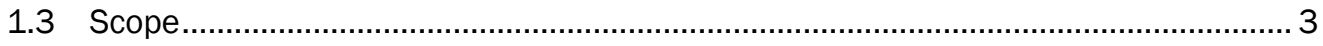

2 Existing Criteria and Other Documentation ........................................................................... 5

2.1 DoD criteria documents............................................................................... 5

2.1.1 UFC 3-260-01: Airfield and Heliport Planning and Design (AFCESA 2008a) ..................... 5

2.1.2 ETL 97-9: Criteria for Design, Maintenance, and Evaluation of Semi-Prepared Airfields for Contingency Operations of the C-17 Aircraft (AFCESA 1997) .......................... 6

2.1.3 ETL 02-19: Airfield Pavement Evaluation Standards and Procedures (AFCESA 2002b)

2.1.4 AFI 13-217: Drop Zone and Landing Zone Operations (U.S. Air Force 2007)..................... 7

2.1.5 ETL 09-6 (Change 1): C-130 and C-17 Landing Zone (LZ) Dimensional, Marking, and Lighting Criteria (AFCESA 2009b).......................................................................... 8

2.1.6 FC 3-260-06F: Air Force Design, Construction, Maintenance, and Evaluation of Snow and Ice Airfields in Antarctica (AFCEC 2015) ......................................................... 8

2.2 Canadian criteria ........................................................................................ 8

2.2.1 AC 301-003: Ice Aerodrome Development-Guidelines and Recommended Practices (Transport Canada 2001).

2.2.2 Canadian Forces Air Command Manual (CFACM) 10-100: Air Transport Group Ice Strip Requirements for CC 130 Hercules, CC 115 Buffalo and CC 138 Twin Otter Operations (Canadian Air Command 1982)............................................................. 8

2.3 Other relevant programs and documents ....................................................... 9

2.3.1 Opportune Landing Sites Program ............................................................................... 9

2.3.2 Allowable Skiway Roughness for LC-130 Operations between 125,000 Ibs and

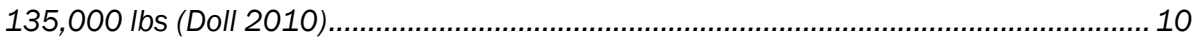

2.3.3 Expedient Military Airfields in Cold Climates (Rollings et al. 2004) .................................... 10

2.4 Criteria that are not relevant to $\mathrm{LZs}$ and DZs ................................................... 10

2.4.1 FM 5-430-00-2/AFJPAM 32-8013: Planning and Design of Roads, Airfields, and Heliports in the Theater of Operations-Airfield and Heliport Design, Vol. II (U.S.

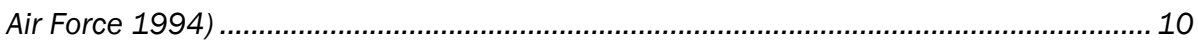

2.4.2 AFI 11-2C-130, Vol. 3: C-103 Operations Procedures (U.S. Air Force 2012) .................... 11

2.4.3 AFI 11-2C-17, Vol. 3: C-17 Operations Procedures (U.S. Air Force 2011)........................ 11

2.4.4 AFI 11-2C-17, Vol. 3, Addenda-C: C-17A Antarctic Operations (U.S. Air Force 2013) 
2.4.5 ETL 09-2: Contingency Airfield Pavement Specifications (AFCESA 2009a) ...................... 11

2.4.6 ETL 08-14: Structural Evaluation Procedure for Stabilized Soil-Surfaced Airfield (AFCESA 2008b)

3 Runway Orientation and Wind Data

4 Landing Zones-Fixed Wing (C-130 and C-17) .................................................................14

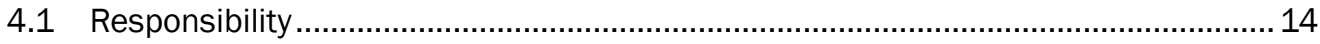

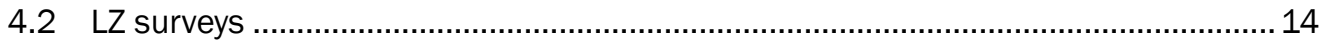

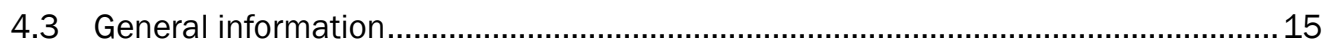

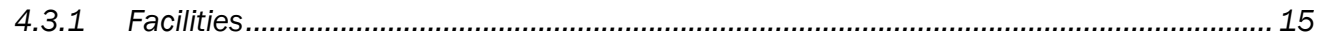

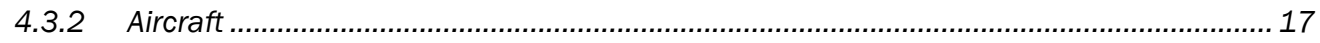

4.4 LZ site planning and considerations................................................................... 18

4.5 Geometric criteria for runways and overruns ................................................... 19

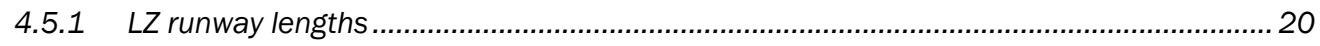

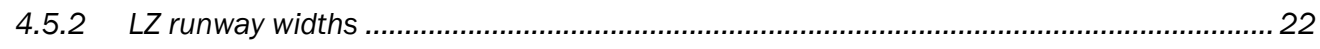

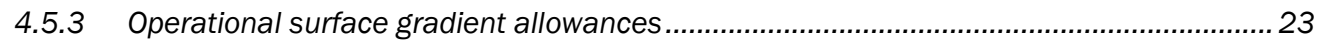

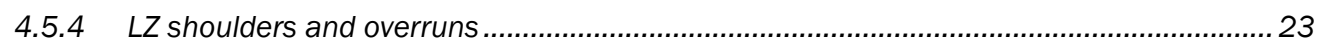

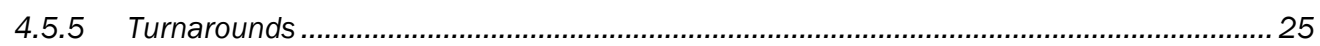

4.5.6 Imaginary surfaces and land-use control areas ........................................................... 25

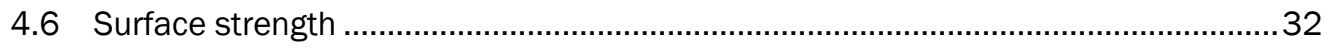

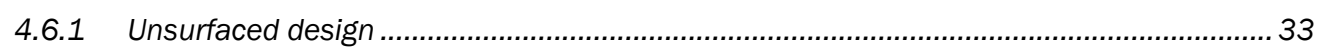

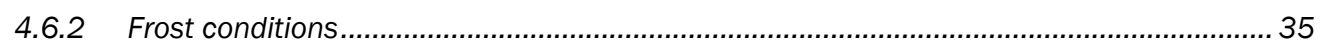

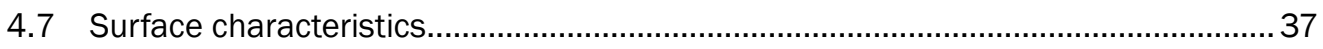

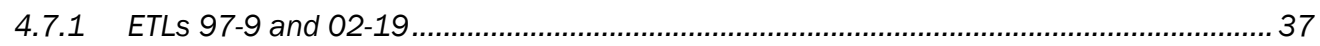

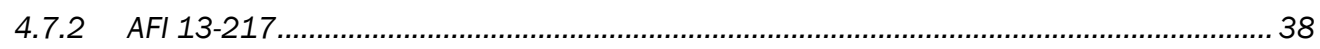

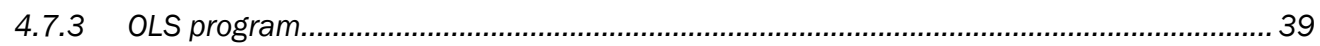

4.8 Surface friction for C-17 contingency operations ............................................ 41

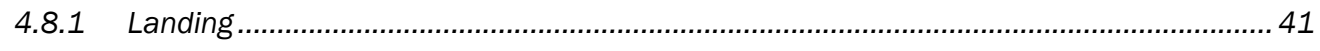

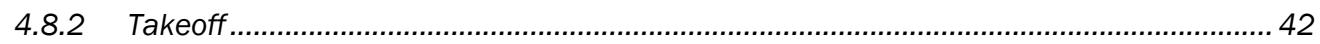

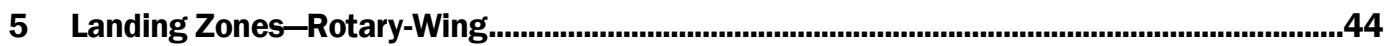

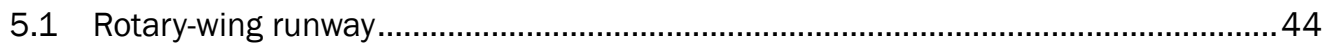

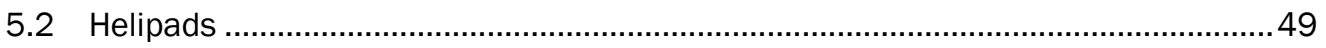

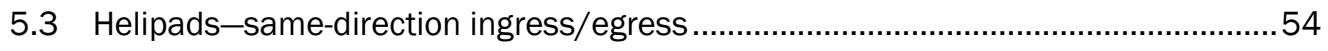

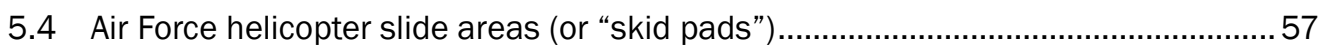

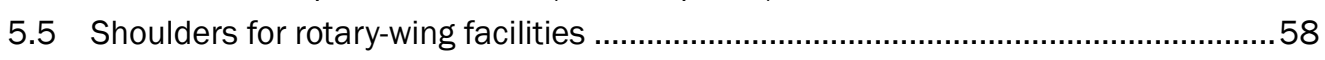

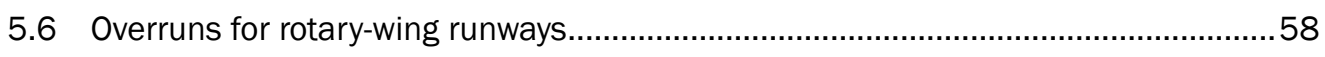

5.7 Clear zone and accident potential zone (APZ) ................................................59

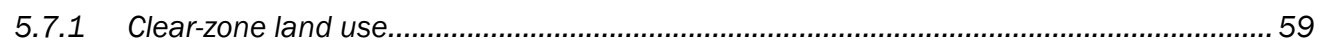

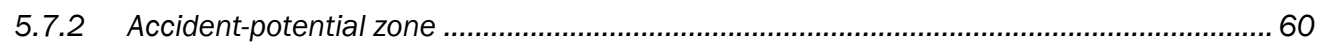

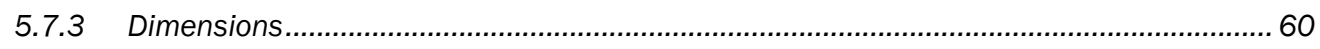

5.8 Imaginary surface for rotary-wing runways and helipads .................................... 61

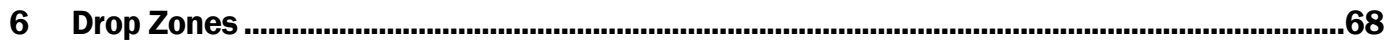

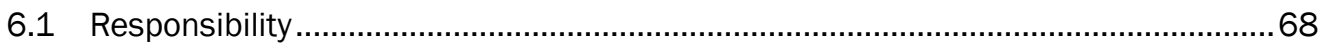

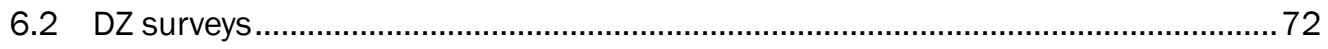




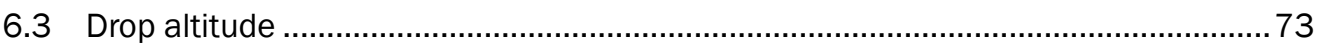

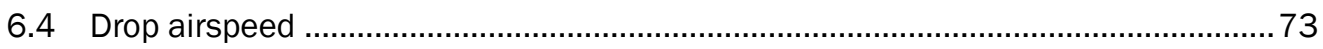

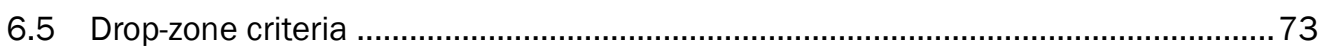

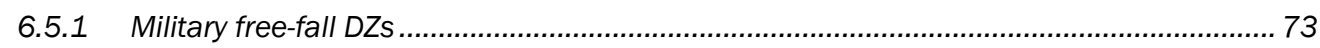

6.5.2 Joint precision airdrop system / improved container delivery system (JPADS/I-

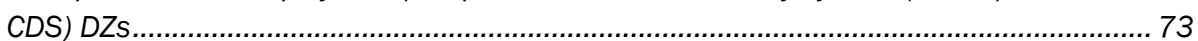

6.5.3 Area DZ

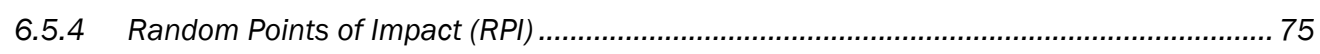

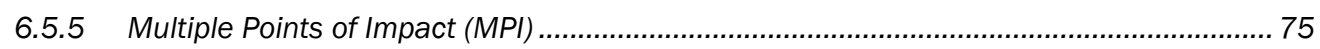

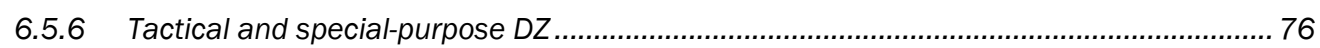

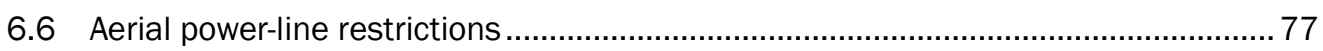

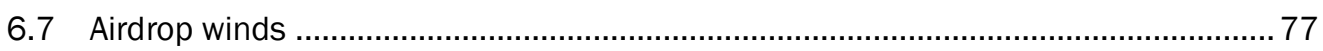

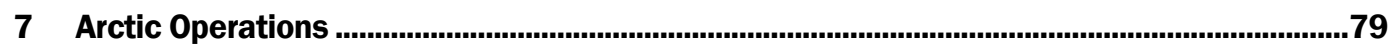

7.1 LC-130 skiway and ski landing area criteria (AFI 13-217) ...................................... 79

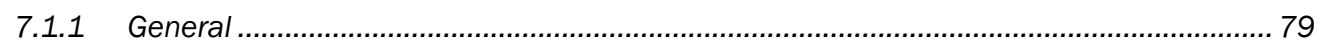

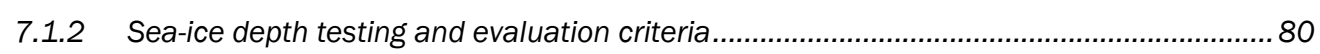

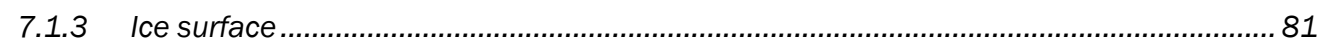

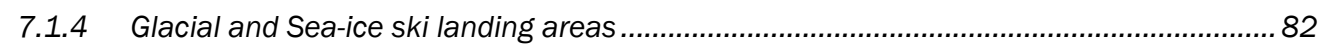

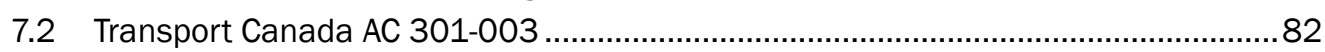

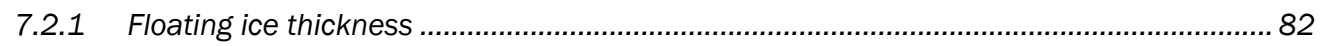

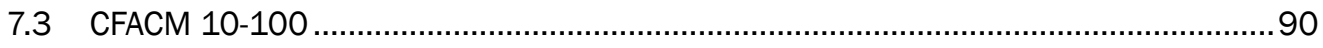

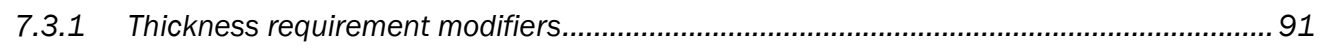

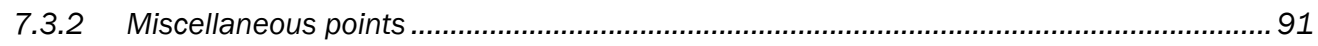

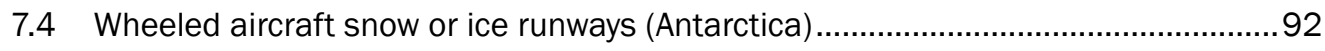

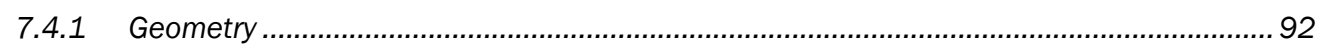

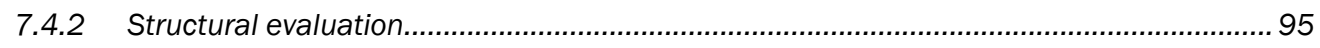

7.4.3 Surface conditions, preparation, and maintenance .........................................................97

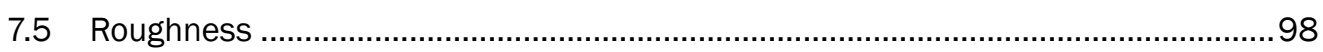

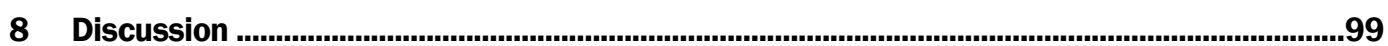

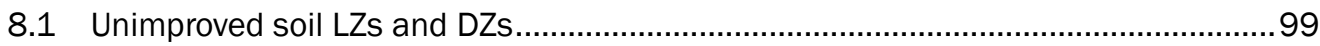

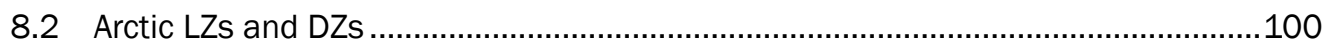

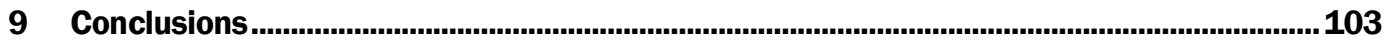

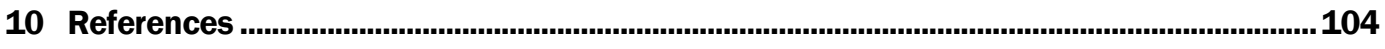

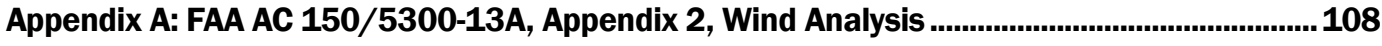

Appendix B: Allowable Skiway Roughness for LC-130 Operations between 125,000

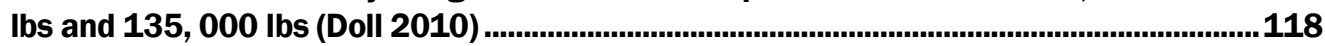

\section{Report Documentation Page}




\section{Figures and Tables}

\section{Figures}

1 LZ primary surface end details (UFC 3-260-01, Fig. 7-1) ...................................................28

2 LZ with contiguous aprons and turnarounds (UFC 3-260-01, Fig. 7-2) ..............................29

3 LZ apron layout details (UFS 3-260-01, Fig. 7-4) ...........................................................30

$4 \quad$ LZ runway imaginary surfaces (UFC 3-260-01, Fig. 7-5).........................................................31

5 LZ runway and apron sections (UFC 3-260-01, Fig. 7-6) …..............................................32

6 Unsurfaced strength requirement for the C-17 aircraft (ETL 97-9, Fig. 4.1) .......................33

7 Soil surface strength requirements for the C-17 aircraft (ETL 02-19, Fig. B-5) ...................34

8 Aggregate or select fill surface thickness requirements for the $\mathrm{C}-17$ aircraft (ETL

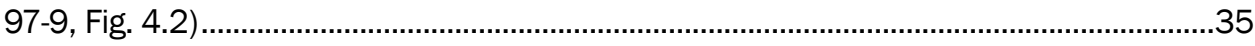

9 Helicopter VFR runway (UFC 3-260-01, Fig. 4-1) ………..................................................4

10 Helicopter IFR runway (UFC 3-260-01, Fig. 4-2).................................................................48

11 IFR airspace imaginary surfaces: IFR Helicopter runways and helipad (UFC 3-

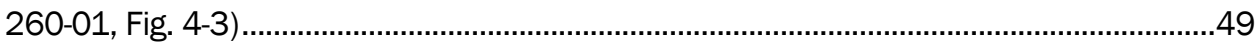

12 Standard VFR Helipad for Army and Air Force (UFC 3-260-01, Fig. 4-4).............................52

13 VFR Helipad for Army Air Force limited use (UFC 3-260-01, Fig. 4-5) ................................53

14 Standard IFR helipad (UFC 3-260-01, Fig. 4-6) ..............................................................54

15 VFR Helipad with same direction ingress/egress (UFC 3-260-01, Fig. 4-7)........................55

16 Army Air Force VFR limited used helipad with same direction ingress/egress (UFC

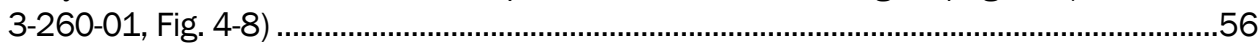

17 IFR Helipad with same direction ingress/egress (UFC 3-260-01, Fig. 4-9) ..........................57

18 Circular DZ computation (AFI 13-217, Fig. 2.1) ………….............................................72

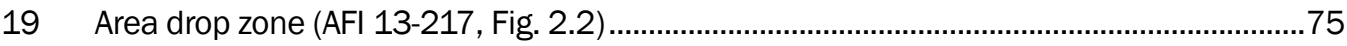

20 Skiway and cargo offload/onload area (AFI 13-217, Fig. 4.2) …………………................82

21 Minimum ice thickness for limited aircraft movement. (Reproduced from

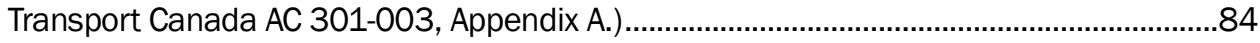

22 Recommended allowable ice flexural stress. (Reproduced from Transport Canada AC 301-003, Appendix B.) .............................................................................

23 Load influence radius of ice covers. (Reproduced from Transport Canada AC

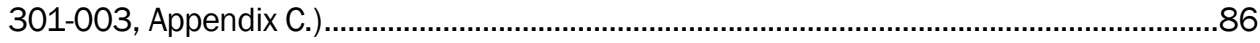

24 Critical taxiing speeds. (Reproduced from Transport Canada AC 301-003,

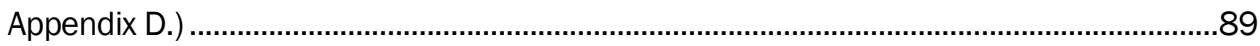

25 Typical runway layout for unidirectional operations (not to scale) (FC 3-260-06F,

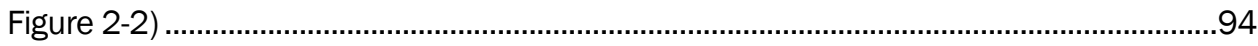

26 Runway surface roughness for landing and take-off (MIL-A-8863C, Figure 1) ................ 102

\section{Tables}

$1 \quad$ Aircraft characteristics (ETL 02-19, Table7) ………...........................................................18

2 Minimum runway criteria for additional aircraft (AFI 13-217, Table 3.1) ............................20 
3 C-17 runway length (ETL 09-6, Table 1). Note that runway lengths do not include

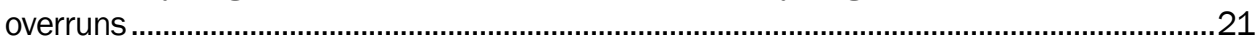

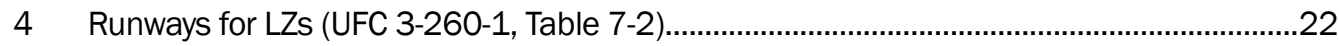

5 Aprons for LZs (UFC 3-260-01, Table 7-4) ......................................................................2

6 Overruns for LZs (UFC 3-260-01, Table 7-5) ………......................................................25

$7 \quad$ Runway end clear zones for LZs (UFC 3-260-01, Table 7-6) ……......................................26

8 Imaginary surfaces for LZs (UFC 3-260-1, Table 7-7) ………........................................26

9 APZs and exclusion areas for LZs (UFC 3-260-1, Table 7-8) .............................................27

10 Frost group designations based on soil classification for frost design (ETL 97-9,

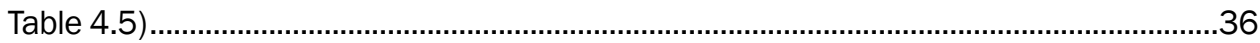

11 Frost Area Soil Support Indexes (FASSIs) (ETL 97-9, Table 4.6).........................................36

12 OLS geometric evaluation rating used for evaluating OLS (Affleck et al. 2008) .................39

13 Surface characteristics used to evaluate OLS (Affleck et al. 2008)....................................40

14 The overall rating of the entire OLS for the C-17 and C-130 (Affleck et al. 2008) ..............41

15 Stopping friction guidance (preliminary) (ETL 97-9, Table D.7).............................................42

16 Correlation between soil type and RCR (ETL 97-9, Table D.8) ...........................................42

17 Rolling-friction guidance (ETL 97-9, Table D.9) ................................................................

18 Rotary-wing runways (UFC 3-260-01, Table 4-1) ............................................................. 44

19 Rotary-Wing helipads (UFC 3-260-01, Table 4-2) ..............................................................51

20 Shoulders for rotary-wing facilities (UFC 3-260-01, Table 4-4) ............................................58

21 Overruns for rotary-wing runways (UFC 3-260-01, Table 4-5) .............................................59

22. Rotary-wing runway clear zone and APZ (UFC 3-260-01, Table 4-6).....................................60

23 Rotary-wing imaginary surfaces for VFR approaches (UFC 3-260-01, Table 4-7)...............62

24 Rotary-wing imaginary surfaces for IFR approaches (UFC 3-260-01, Table 4-8) ...............64

25 Standard DZ size criteria (AFI 13-217, Table 2.1) ……………………………………....69

26 Standard point of impact placement (AFI 13-217, Table 2.2) ............................................76

27 Surface-wind limits for CDS equipment airdrops (AFI 13-217, Table 2.3) ............................78

28 Surface-wind limits for personnel airdrops (AFI 13-217, Table 2.4) ....................................78

29 Ice weight-bearing capacity (AFI 13-217, Table 4.1) .........................................................8

30 Adjustments for cracked ice. (Reproduced from Transport Canada AC 301-003.).............87

31 Runway dimensional requirements for C-130, LC-130, and C-17 operations (FC 3-260-06F, Table 2-1) 


\section{Preface}

This study was conducted for the Army Terrestrial Environmental Modeling and Intelligence System (ARTEMIS) program under Work Item 9K3D08 for the Geospatial Remote Assessment for Ingress Locations (GRAIL) project. The technical monitors were Mr. Randy Hill (CEERDRV) and Mr. J ohn Eylander (CEERD-RR).

The work was performed by the Force Projection and Sustainment Branch (CEERD-RRH), U.S. Army Engineer Research and Development Center, Cold Regions Research and Engineering Laboratory (ERDC-CRREL). At the time of publication, Dr. J ustin Berman was Acting Chief, CEERDRRH. The Deputy Director of ERDC-CRREL was Dr. Lance Hansen, and the Director was Dr. J oseph L. Corriveau.

Ms. Lynette Barna and Ms. Ariana Sopher provided excellent review comments.

COL Bryan S. Green was the Commander of ERDC, and Dr. David W. Pittman was the Director. 


\section{Acronyms and Abbreviations}

AC

AFCEC

AFCEE

AFCESA

AFI

AFJ PAM

AFMAN

AFRPA

AICUZ

APZ

APZ-LZ

ARTEMIS

CBR

CDS

CFACM

CRG

CRREL

DoD

DZ

ERDC

ETL

FAA
Advisory Circular

Air Force Civil Engineer Center

Air Force Center for Engineering and the Environment

Air Force Civil Engineer Support Agency

Air Force Instruction

Air Force J oint Pamphlet

Air Force Manual

Air Force Real Property Agency

Air Installation Compatible Use Zone

Accident Potential Zone

Accident Potential Zone- Landing Zone

Army Terrestrial Environmental Modeling and Intelligence System

California Bearing Ratio

Container Delivery System

Canadian Forces Air Command Manual

Contingency Response Group

U.S. Army Cold Regions Research and Engineering Laboratory

Department of Defense

Drop Zone

Engineer Research and Development Center

Engineering Technical Letter

Federal Aviation Administration 


\begin{tabular}{|c|c|}
\hline FASSI & Frost Area Soil Support Index \\
\hline FC & Facilities Criteria \\
\hline FM & Field Manual \\
\hline GeoExPT & Geospatial Expeditionary Planning Tool \\
\hline GIS & Geographic Information System \\
\hline GPS & Global Positioning System \\
\hline GRAIL & Geospatial Remote Assessment for Ingress Locations \\
\hline I-CDS & Improved Container Delivery System \\
\hline IFR & Instrument Flight Rules \\
\hline JPADS & J oint Precision Airdrop System \\
\hline LZ & Landing Zone \\
\hline MPI & Multiple Points of Impact \\
\hline NAVAID & Navigational Aid \\
\hline n.m. & Nautical Miles \\
\hline OLS & Opportune Landing Sites \\
\hline PADS-MP & Precision Airdrop System Mission Planner \\
\hline PCASE & $\begin{array}{l}\text { Pavement Transportation Computer Assisted Structural } \\
\text { Engineering }\end{array}$ \\
\hline PI & Point of Impact \\
\hline RED HORSE & $\begin{array}{l}\text { Rapid Engineer Deployable Heavy Operations Repair Squadron } \\
\text { Engineer }\end{array}$ \\
\hline RCR & Runway Condition Rating \\
\hline RPI & Random Points of Impact \\
\hline SIPRE & Snow, Ice, and Permafrost Research Establishment \\
\hline SLACO & Skiway Landing Area Control Officer \\
\hline
\end{tabular}




$\begin{array}{ll}\text { UFC } & \text { Unified Facilities Criteria } \\ \text { USACE } & \text { United States Army Corps of Engineers } \\ \text { USAF } & \text { United States Air Force } \\ \text { VFR } & \text { Visual Flight Rules }\end{array}$




\section{Unit Conversion Factors}

\begin{tabular}{|l|l|l|}
\hline Multiply & By & To Obtain \\
\hline degrees (angle) & 0.01745329 & radians \\
\hline degrees Fahrenheit & $(\mathrm{F}-32) / 1.8$ & degrees Celsius \\
\hline feet & 0.3048 & meters \\
\hline inches & 0.0254 & meters \\
\hline knots & 0.5144444 & meters per second \\
\hline miles (nautical) & 1,852 & meters \\
\hline pounds (force) per square inch & 6.894757 & kilopascals \\
\hline pounds (mass) & 0.45359237 & kilograms \\
\hline square inches & $6.4516 \mathrm{E}-04$ & square meters \\
\hline yards & 0.9144 & meters \\
\hline
\end{tabular}




\section{Introduction}

\subsection{Background}

Establishment of expeditionary or contingency runways and heliports, designated as landing zones (LZs) and drop zones (DZs), for dispersal of cargo or personnel in remote and often austere locations is critical to the modern United States military. Operations occur across the globe in areas where the infrastructure does not exist to support airlift, which expedites the infusion of both personnel and supplies into the region for humanitarian or military concerns.

Specifically trained teams of personnel who are often active-duty military members perform the initial survey and assessment of potential LZ or DZ operations areas. These locations may be inhospitable, near locations under hostile control or that have suffered a natural or humanitarian disaster.

Several programs are looking at ways to remotely assess sites for various military operations. With regard to potential LZ or DZ sites, the goal is to limit the need for or duration of survey teams on the ground prior to aircraft landings or airdrop operations.

The Opportune Landing Site (OLS) program used commercially available LANDSAT imagery to remotely locate unimproved landing sites in natural terrain. The program considered geometry, soil strength, and surface characteristics (i.e., lack of vegetation and other obstructions) to give an overall OLS rating used for identifying potential LZs for C-130 and C-17 aircraft (Affleck et al. 2008, 2009; Barna et al. 2008; Danyluk et al. 2008).

The Army Terrestrial Environmental Modeling and Intelligence System, Geospatial Remote Assessment for Ingress Locations (ARTEMIS-GRAIL), program is using similar methods to remotely identify areas suitable for vehicle maneuvers. This program bases its recommendations on slope, roughness, vegetation, soil type, and wetness by using WorldView- 2 multispectral satellite imagery and "training" the analysis with ground truth data from field soil tests at specific sites (Sopher et al. 2016). 
GeoExPT (Geospatial Expeditionary Planning Tool), used by the U.S. Airforce and Army, is designed to be a decision support tool for planners, providing the means to create geospatially accurate base layout plans, meet contingency bed-down requirements, automate aircraft parking, manage airfield damage, and select Minimum Airfield Operating Strips. GeoExPT is built on top of a GIS (geographic information system) platform and can be used with either ArcEngine or ArcGIS. Like the OLS program, GeoExPT and its GIS platform use LANDSAT imagery (Engineering Technical Letter [ETL] 13-3).

For these remote-sensing programs to be successful at identifying potential sites for aircraft operations, the specific criteria for potential LZs or DZs must be defined and a determination made as to which of these criteria may be determined remotely. Again, the goal is to eliminate, or at least reduce, the need for personnel on-site making field measurements to determine the suitability of potential LZs and DZs.

LZs (formerly called Short Fields or Training Assault Landing Zones) are special-use fields for warfighting or contingency response (and are therefore also known as contingency airfields). Contingency operations, as defined by the U.S. Air Force and for the purposes of this report, are normally short-term operations connected with conflicts or emergencies (Unified Facilities Criteria [UFC] 3-260-01).

Airfields for contingency operations can be paved or unpaved. Because operations are limited, structural requirements are not as great as for permanent installations. In addition, higher risk to aircraft and personnel may be justified, so requirements such as clearances are not as stringent (ETL 979).

A fixed-wing LZ consists of a runway with contiguous turnarounds (hammerheads) and aprons. It is a prepared or semi-prepared (unpaved, gravel, or soil) airfield used to conduct operations in an airfield environment similar to forward-operating locations. LZ runways are typically shorter and narrower than standard runways (UFC 3-260-01, ETL 09-6). LZs may have taxiways; however, this report does not consider that type of facility.

Helicopter (rotary-wing) LZs consist primarily of a runway and helipad surface. The contingency LZ for a helicopter represents the minimum 
cleared area to discharge or pick up passengers, and geometric requirements are kept to the absolute minimum.

The aircraft landing and takeoff design considerations for military LZ airfields include mission requirements; expected type and volume of air traffic (either fixed or rotary wing); traffic patterns, such as the arrangement of multidirectional approaches and takeoffs; ultimate runway length; runway orientation required by local wind conditions; local terrain; restrictions due to airspace obstacles or surrounding communities; and possibly noise potential and aircraft accident potential. DZs require a similar set of considerations.

\subsection{Objective}

This report intends to serve as a summary of current (2017) criteria for the siting of unsurfaced, unimproved LZs and DZs used by the U.S. Army and Air Force. This summary includes construction in arctic climates. The purpose of the summary is to consolidate criteria so that the criteria may be considered in the process of developing and refining methods to remotely locate and assess potential LZs and DZs by using satellite imagery. Therefore, this review includes a brief discussion of the gaps in the criteria and which criteria may be most compatible to remote sensing.

\subsection{Scope}

This report briefly discusses the responsible parties for siting LZs and DZs, including approval authorities and those agencies that are responsible for the initial site surveys as they are currently performed. This would be a factor when considering who would approve and bear the responsibility for remotely assessed sites.

The report will focus on the geometric requirements and imaginary airspace surfaces, runway orientation with regard to wind characteristics, and other siting criteria. It will not discuss potential site improvements such as soil stabilization, grading, or any type of paving or maintenance action. For the purposes of this report, acceptable sites should need no improvement prior to aircraft operations.

It will also attempt to summarize the current methods and criteria for evaluating the structural requirements (surface bearing capacity) to support aircraft operations. Evaluating structural characteristics is less 
straightforward as many factors influence ground surface strength and it is very site specific. The report also covers ground surface characteristics such as smoothness or roughness criteria and friction criteria.

The details for these facilities are varied. Depending on the region, LZs and DZs may need to be surfaced, or unsurfaced, and may be constructed on soil, snow, or ice. However some criteria are common to all scenarios, such as required runway length for specific aircraft and airfield imaginary surface dimensions. Airfield imaginary surfaces are surfaces in space established around airfields in relation to runways, helipads, or helicopter runways that are designed to define the obstacle-free airspace around the airfield in which the aircraft operate.

As these sites will be used for contingency operations, this report will not address issues such as noise, land use, endangered species, cultural assets, and other environmental factors that would be considered for permanent installations, particularly within the United States and its territories, in peacetime or nonemergency circumstances.

For arctic operations, this report also reviews other applicable criteria from outside the Department of Defense (DoD). In particular, Canada has produced documentation directly relevant to the Arctic airfields. This report also summarizes several applicable research papers for arctic operations. In artic regions, ground surface materials may include frozen ground, snow, and ice, whose properties are temperature dependent and provide perhaps a more variable platform than standard soil locations. This makes determining parameters such as structural capacity more challenging.

The guidance summarized in this document is pulled directly from U.S. and Canadian government publications. Much of the text is verbatim; other text has been modified only for clarity. Guidance outside the scope of austere LZs and DZs has been omitted. Tables and figures are excerpted directly from the criteria documents and therefore may contain references specific to the particular document. This summary is in no way intended to present the criteria in their entirety. Please refer to the source documents for complete guidance. Additionally, the DoD revises its criteria frequently, and documents referenced in this report are subject to revision or replacement. 


\section{Existing Criteria and Other Documentation}

Several DoD and other documents are pertinent to the criteria or guidance available for siting LZs and DZs. Below is a listing of the documentation reviewed for this report with a brief summary of the information each provides. The list attempts to present the documents in the order of relevance. For completeness, it also lists several documents that deal with related subjects but that are not necessarily relevant to contingency operations.

The DoD and military criteria referenced in this review include Air Force Manuals (AFMAN), Engineering Technical Letters (ETLs), and Air Force Instructions (AFI) generated by the Air Force and Field Manuals (FM) generated by the Army. Some documents are joint service and have dual designations FM/ AFJ PAM (Air Force J oint Pamphlet) or UFC (Unified Facilities Criteria) designations. The Facilities Criteria (FC) designation indicates criteria specific to one DoD competent (i.e. FC 3-260-06F with the " $F$ " designation indicating Air Force). There are documents that are exceptions to these standard designations.

Also, as of 2012, the Air Force Civil Engineer Support Agency (AFCESA), the preparing agency for a majority of these criteria, merged with the Air Force Real Property Agency (AFRPA) and the Air Force Center for Engineering and the Environment (AFCEE) to form the Air Force Civil Engineer Center (AFCEC).

\subsection{DoD criteria documents}

\subsubsection{UFC 3-260-01: Airfield and Heliport Planning and Design (AFCESA 2008a)}

UFC 3-260-01 provides specific criteria for the planning and design of new permanent facilities (runways, taxiways, aprons and parking areas, and shoulders and overruns) for all four services. The UFC defines all terms, discusses facilities planning, siting, geometry and dimensions of runways and their associated clear and accident-potential zones, and airspace imaginary surfaces.

UFC Chapter 7 discusses contingency operations, also known as theater of operations, LZs for C-130 and C-17 aircraft. The C-130 and C-17 are the 
current (2017) aircraft in the Air Force inventory that are used for tactical airlift to unimproved and semi-improved runways or LZs.

UFC Chapter 4 discusses rotary-wing runways and helipads, though not specifically from a theater-of-operations standpoint.

The UFC also includes Navy and Marine Corps criteria where they differ from that used by the Army and Air Force. Because this review focuses on Army and Air Force criteria, Navy and Marine Crops criteria are not looked at in detail, and their criteria appear only where they are the same as or were combined with that of the Army and Air Force.

Appendix B, Section 4, of the UFC provides information on wind-coverage studies and their applicability to runway siting and orientation.

UFC 3-260-01 does not discuss pavement design or required soil structural or bearing capacity of a site to support aircraft operations. UFC 3260-02: Pavement Design for Airfields (USACE 2001) presents this. The criteria in UFC 3-260-02 are beyond the scope of this review.

\subsubsection{ETL 97-9: Criteria for Design, Maintenance, and Evaluation of Semi- Prepared Airfields for Contingency Operations of the C-17 Aircraft (AFCESA 1997)}

This document contains the specifications of the C-17 aircraft itself and criteria for the geometry of the LZ features and imaginary surfaces that are presented in UFC 3-260-01. It provides no DZ information.

A "semi-prepared" airfield refers to an unpaved airfield. The amount of engineering effort required to develop a semi-prepared airfield depends on the planned operation, the service life needed to support these operations, and the existing soil and weather conditions. Semi-prepared construction and maintenance preparations may range from those sufficient for limited use to those required for continuous routine operations. Options for surface preparation may include stabilization, addition of an aggregate course, compaction of in-place soils, or installation of surface matting.

The ETL also contains information on surface requirements such as soil strength, surface condition (i.e., potholes, ruts, loose aggregate, dust, and rolling resistance), frost conditions, and structural evaluation procedures 
for the proposed surface. Also included are maintenance procedures, which are not within the scope of this summary.

Finally, Appendices C and D of the ETL present the basic criteria and procedures used to determine whether a semi-prepared contingency airfield is suitable for C-17 operations in terms of structural evaluation procedures, surface-friction characteristics, and usable runway length.

\subsubsection{ETL 02-19: Airfield Pavement Evaluation Standards and Procedures (AFCESA 2002b)}

This ETL presents the basic criteria and procedures used to determine using conventional evaluation procedures the structural suitability or loadbearing capability of an airfield to sustain aircraft operations. It also presents the procedure for evaluating the surface condition of unsurfaced or aggregate-surface airfields. It does not provide geometric guidance for either the runway itself or the associated airspace. It includes the evaluation of existing airfields for contingency use by U.S. aircraft and discusses paved, semi-prepared (gravel/ unsurfaced), and LZ airfields.

The Headquarters AFCESA [now AFCEC] Pavement Evaluation Team assesses the structural capability of airfields for projection of U.S. forces in support of regional conflicts or peacetime human relief operations. Other Air Force units such as RED HORSE (Rapid Engineer Deployable Heavy Operations Repair Squadron Engineer) squadrons, Air Mobility Operations Groups, Tanker Airlift Control Elements, Contingency Response Groups, and Special Tactics Teams are also tasked with performing airfield evaluations. These personnel are trained and certified and require annual recurring training to kept their certifications current. The frequency of these taskings have increased substantially in recent years and have highlighted the need to ensure that those tasked are sufficiently trained and to standardize evaluation procedures.

\subsubsection{AFI 13-217: Drop Zone and Landing Zone Operations (U.S. Air Force 2007)}

AFI 13-217 provides guidance on DZ and LZ physical criteria, including siting and geometry, and aircraft operational procedures. Chapter 4 , of the AFI also provides LC-130 skiway and ski landing area criteria. The content of the AFI is discussed in detail in Chapter 5 of this review. 
2.1.5 ETL 09-6 (Change 1): C-130 and C-17 Landing Zone (LZ) Dimensional, Marking, and Lighting Criteria (AFCESA 2009b)

ETL 09-6 provides geometric criteria for LZ runways, aprons, and imaginary surfaces. It specifically references ETL 97-9 for semi-prepared (unpaved) surfaces. The content of this document is discussed in Chapter 5 of this review.

\subsubsection{FC 3-260-06F: Air Force Design, Construction, Maintenance, and Evaluation of Snow and Ice Airfields in Antarctica (AFCEC 2015)}

This document supersedes AFCESA ETL 02-16 (Design, Construction, Maintenance, and evaluation of the Pegasus Glacial Ice Runways for Heavy Wheeled Aircraft Operations) and ETL 07-12 (Design, Construction, Maintenance and Evaluation of the McMurdo Sound [Antarctica] Sea Ice Runaway for Heavy Wheeled Aircraft Operations.

The FC applies only to runways and specifically refers skiway operations to AFI 13-217. Additionally, this FC is specifically for operations with the trained personnel at McMurdo Station and the equipment available in the McMurdo motor pool. For the purposes of this review, therefore, only some of the basic information about geometry, surface strength, and surface characteristics will be summarized.

\subsection{Canadian criteria}

\subsubsection{AC 301-003: Ice Aerodrome Development-Guidelines and Recommended Practices (Transport Canada 2001)}

This AC provides a set of guidelines or best practices for the development, operations, and on-going maintenance of ice aerodromes. It includes site considerations, floating ice thickness requirement for aircraft operations (including consideration of resonance), and a list of general best practices.

\subsubsection{Canadian Forces Air Command Manual (CFACM) 10-100: Air}

Transport Group Ice Strip Requirements for CC 130 Hercules, CC 115 Buffalo and CC 138 Twin Otter Operations (Canadian Air Command 1982)

This document does discuss the bearing capacity of ice, including resonance wave effect of bearing capacity and load influence radius. However, because of its publication date and the fact that it acknowledges the source 
of the majority of its graphs and data is from other agencies' documents and work, this review will not summarize its strength calculation methods.

Other qualitative information in this document worth noting is included in the appropriate sections.

\subsection{Other relevant programs and documents}

\subsubsection{Opportune Landing Sites Program}

In addition to the above published military criteria, recent work has considered the problems of remotely locating large, smooth, flat, and obstruction-free areas, termed Opportune Landing Sites (OLSs), that are also sufficiently firm to support at least one aircraft landing and taking off, and preferably many additional aircraft operations following that.

The OLS Program, managed by the Air Vehicles Directorate at the Air Force Research Laboratory at Wright-Patterson Air Force Base in partnership with the U.S. Army Corps of Engineers, Engineer Research and Development Center (USACE-ERDC), and the Boeing Company, applied existing technologies to rapidly accelerate the process of selecting OLSs using remote-sensing technology (LANDSAT imagery) and state-of-the-ground forecast tools (Affleck et al. 2008, 2009; Barna et al. 2008; Danyluk et al. 2008).

The OLS program used commercially available LANDSAT imagery to remotely locate unimproved landing sites in natural terrain. Available LANDSAT imagery identified areas that were sufficiently flat and free of heavy vegetation, obstacles, and surface water to allow airlift operations, soil and weather conditions permitting.

Once a potential site was identified, the second module of the OLS program, also developed by Boeing, determined the soil type based on the pixelated satellite imagery and digital terrain evaluation data.

Finally, the third module of OLS software used inputs of soil type and measured or modeled weather data to predict the soil moisture content and to infer the soil California bearing ratio (CBR). CBR is in turn used to evaluate the trafficability of the site by a specific aircraft. This work built a substantial database of soil strength and associated soil physical property data (Shoop et al. 2008). 
Some of the criteria developed under the OLS program were based on prior criteria; UFC 3-260-02 was used as a basis for allowable gross loads and aircraft passes, and ETL 97-9 was used for rating and classifying surface distress levels (Affleck et al. 2008).

\subsubsection{Allowable Skiway Roughness for LC-130 Operations between $125,000 \mathrm{lbs}$ and 135,000 lbs (Doll 2010)}

This document itself is a review of criteria and other sources on the subject of overall skiway roughness for LC-130 operations. Appendix B presents it in its entirety. The references cited in Doll's review were not necessarily reexamined for this review.

\subsubsection{Expedient Military Airfields in Cold Climates (Rollings et al. 2004)}

This report discusses the adaptation of research and private-sector-industry efforts with roads and airfields in the Arctic to the problem of constructing military airfields under those extreme conditions. Most of the discussion in the report involves construction activities outside of the scope of this review. However, the frozen ground discussion does suggest using current layered pavement analysis, treating the frozen soil as a layer within the system, to predict strength for the support of aircraft operations. The report concludes, "these analysis methods need refinement and verification but illustrate an approach and potential for frozen ground to support military logistical aircraft operations." No further review of this document is included.

\subsection{Criteria that are not relevant to $\mathrm{LZs}$ and DZs}

Several other DoD documents contain information on airfields and other surfaces that are not specific to LZ and DZ criteria but that provide a basis for those design parameters.

2.4.1 FM 5-430-00-2/AFJPAM 32-8013: Planning and Design of Roads, Airfields, and Heliports in the Theater of Operations-Airfield and Heliport Design, Vol. II (U.S. Air Force 1994)

FM 5-430-00-2 is a comprehensive and lengthy document that fully discusses expedient-surfaced airfields in Chapter 12. It provides useful general information on the runway siting and validation process; but for theater of operations, the information in Section 7 of UFC 3-260-01 supersedes the information in the FM for C-17 and C-130 LZs (UFC 3-260-01). 
FM 5-430-00-2 uses different terminology than subsequent documents. The FM uses the term "expedient-surfaced" airfields as one of three airfield structure categories: expedient surfaced, aggregate surfaced, and flexible pavement. Expedient-surfaced and aggregate-surfaced airfields are defined as used primarily in the close battle and support areas. For expedient-surfaced airfield, the in-place soil strength determines the number of aircraft passes. If the mission requires a longer surface life, measures to improve the in-place soil are required. Unsurfaced deserts, dry lake beds, and flat valley floors serve as possible airfield sites. Normally, expedientsurfaced airfields are used for very short periods of time (0-6 months). They require very little initial construction but may require extensive daily maintenance. FM 5-430-00-2 uses the term "landing zone (LZ)" primarily for heliports.

\subsubsection{AFI 11-2C-130, Vol. 3: C-103 Operations Procedures (U.S. Air Force 2012)}

This AFI is about aircraft operations and does not provide criteria for infrastructure requirements.

\subsubsection{AFI 11-2C-17, Vol. 3: C-17 Operations Procedures (U.S. Air Force 2011)}

This AFI is about aircraft operations and does not provide criteria for infrastructure requirements.

2.4.4 AFI 11-2C-17, Vol. 3, Addenda-C: C-17A Antarctic Operations (U.S. Air Force 2013)

This AFI is about aircraft operations and does not provide criteria for infrastructure requirements.

\subsubsection{ETL 09-2: Contingency Airfield Pavement Specifications (AFCESA 2009a)}

This ETL provides paving criteria beyond the scope of siting LZs in areas that require no improvement prior to aircraft operations. 
2.4.6 ETL 08-14: Structural Evaluation Procedure for Stabilized SoilSurfaced Airfield (AFCESA 2008b)

This ETL provides criteria for stabilizing soils for the purposes of increasing bearing capacity and is beyond the scope of siting LZs in areas that require no improvement prior to aircraft operations. 


\section{Runway Orientation and Wind Data}

One factor in determining runway orientation is wind coverage. Per UFC 3-260-01, runway orientation based on wind coverage for Army and Air Force airfields will be determined in accordance with the methodology presented in Federal Aviation Administration (FAA) AC 150/5300-13A (2012), "Appendix 2: Wind Analysis" (included as Appendix A of this report). The wind data analysis considers the wind speed and direction as related to the existing and forecasted operations during visual and instrument meteorological conditions. It may also consider wind by time of day.

The Army stipulates the runway orientation should obtain 95\% wind coverage with a maximum $19.5 \mathrm{~km} / \mathrm{hr}$ (10.5 knot) crosswind. If this coverage cannot be attained, a crosswind runway is desirable.

The Air Force uses other criteria presented in AFMAN 32-1084, Facility Requirements (2016), for authorization of a crosswind runway. This review considers LZs with only a single runway; crosswind runways are not applicable. Appendix E of ETL 97-9 indicates the crosswind limit for the C17 is 30 knots (ETL 97-9). None of the DoD criteria reviewed specifically designate the crosswind limit for the C-130 aircraft. However, various aircrew certification training sources cite a value of 35 knots. 


\section{Landing Zones-Fixed Wing (C-130 and C- 17)}

U.S. Army FM 5-430-00-2 and Chapter 7 of UFC 3-260-01 provide guidelines for fixed-wing facilities within the theater of operations for C-17 and C-130 LZs. The information in UFC Chapter 7 supersedes the information in the FM (UFC 3-260-01). However, criteria to be used in a specific theater of operations is based on local conditions and is determined by Army and Air Force staff engineers acting for the joint force commander (AFI 13217). AFI 13-217 also contains operational standards.

\subsection{Responsibility}

The air component commander with the other component commanders and the joint force engineer determine the most suitable locations for LZs. J oint force special operations component commander forces determine suitable LZ locations from joint special operations air component commander recommendations. In all cases, selected sites must meet Air Force operational, ground-component, and construction requirements.

\subsection{LZ surveys}

Contingency Response Group (CRG) airfield assessment teams include AFCEC personnel that are qualified to conduct surveys of prepared and semi-prepared LZs. Other Air Force units such as RED HORSE Squadrons and Special Tactics Teams are also tasked to perform contingency evaluations of semi-prepared airfields.

Combat control personnel are trained and equipped with a full suite of surveying equipment that can satisfactorily assess obstructions, penetrations, and approach-zone clearances and can check the weight-bearing capability of LZs for both semi-prepared and prepared surfaces.

Although qualified combat control personnel can establish the usability of hard-surface LZs for temporary operations, AFI 13-217 recommends that AFCEC or some other dedicated civil engineering agency with more robust equipment (Electronic Cone Penetrometer, Heavy Weight Deflectometer, etc.) be used for sustained operations (AFI 13-217). 
Combat control personnel who are graduates of the AFCEC Contingency Airfield Pavement Evaluation Course are qualified to perform structural evaluations of all types of pavement surfaces (hard or unsurfaced) and to determine the allowable number of passes and maximum weights of aircraft that can safely use these surfaces. When results of these structural evaluations exhibit uncharacteristic results, these personnel are trained to forward the data to the major command pavement engineer for final determination.

The assessment team gathers data from the on-site survey, prepares an LZ survey package using form AF MIT 3822, Landing Zone Survey, and recommends approval or disapproval to the appropriate agency for use (ETL 13-217 2007).

\subsection{General information}

\subsubsection{Facilities}

Chapter 7 of UFC 3-260-01 (2008) specifically addresses criteria for contingency LZs for C-130 and C-17 aircraft. LZs for C-130s and C-17s are special-use airfields for war fighting or contingency response. Chapter 7 of the UFC provides geometric criteria and land-use guidelines for areas near L7s constructed for C-130 and C-17 aircraft. It includes criteria for the runways, taxiways, aprons, and airspace requirements and addresses construction of non-airfield-related facilities near the airfield for both austere and developed areas.

This review will focus on runways with contiguous turnarounds (hammerheads) and aprons. The wording for prepared surfaces remains though unimproved areas are the focus of this review. CRG airfield assessment teams include AFCEC personnel that are qualified to conduct surveys of prepared and semi-prepared LZs.

The following terms are defined by UFC 3-260-01 (2008):

- Accident Potential Zone- Landing Zone (APZ-LZ): The land-use control area beyond the clear zone of an LZ that possesses a significant potential for accidents (Therefore, land use is a concern.) 
- Apron: On an airfield, a defined area intended to accommodate aircraft for the purposes of loading or unloading passengers or cargo, refueling, parking, or maintenance

- Clear Zone-LZ: A surface on the ground or water, beginning at the runway threshold and symmetrical about the extended runway centerline, that is graded to protect aircraft operations

- Contingency Operations: Typically, short-term operations conducted in support of conflicts or emergencies

- Exclusion Area: Areas required for all paved and semi-prepared (unpaved) LZs-The purpose of the exclusion area is to restrict the development of facilities around the LZ. Only features required to operate the LZ are permissible in the exclusion area, such as operational surfaces (e.g., taxiways and aprons), NAVAIDs (navigational aids), aircraft and support equipment, and cargo loading and unloading areas and equipment. In addition, only properly sited facilities are allowed in this area (see Section 13 of Appendix B in UFC 3-260-01).

- Graded Area: An area beyond the runway shoulder where grades are controlled to prevent damage to aircraft that may depart the runway surface

- Imaginary Surfaces-LZ: Surfaces in space established around an LZ in relation to runways, helipads, or helicopter runways and designed to define the protected airspace around the airfield-The imaginary surfaces for LZs are the primary surface and approach-departure clearance surface.

- Overrun Area: Area the width of the runway plus shoulders extending from the end of the runway to the outer limit of the end zone-The overrun-area is a prolongation of the stabilized runway surface.)

- Runway: A defined rectangular area of an airfield or heliport, with no curves or tangents, prepared for the landing and takeoff run of aircraft along its length

- Shoulder: Prepared (paved or unpaved) area adjacent to the edge of an operational pavement 
An LZ consists of a runway, a runway and taxiway, or other aircraft operational surfaces (e.g., aprons or turnarounds). It is a prepared or semi-prepared (unpaved) airfield used to conduct operations in an airfield environment similar to forward-operating locations. LZ runways are typically shorter and narrower than standard runways. Semi-prepared-surface structural requirements for training airfields are more stringent than those for contingency airfields as they are constructed for long-term operations.

A paved LZ is a prepared and surfaced site designed to carry aircraft traffic. Paved LZs were formerly called "short fields" and later known as "prepared assault landing zones." The principal components of a paved LZ include one of the following:

- A flexible or nonrigid pavement, or one that includes a bituminous concrete surface course designed as a structural member with weatherand abrasion-resistant properties

- A rigid pavement, or one that contains Portland cement concrete as an element

- A combination of flexible and rigid pavement layers, such as an overlay, where a flexible pavement is placed over an existing rigid pavement layer to strengthen the rigid pavement layer

A semi-prepared LZ refers to an unpaved LZ. The amount of engineering effort required to develop a semi-prepared LZ depends on the planned operation, the service life needed to support these operations, and the existing soil and weather conditions. Semi-prepared construction and maintenance preparations may range from those sufficient for limited use to those required for continuous, routine operations. Options for surface preparation may include stabilization, adding an aggregate course, compacting in-place soils, or matting.

\subsubsection{Aircraft}

Again, the C-130 and C-17 are the current (2015) aircraft in the Air Force inventory that are used for tactical airlift to unimproved and semi-improved runways or LZs. ETL 02-19 (2002), however, provides a convenient table (Table 1) of aircraft characteristics and basic runway geometry requirements for seven aircraft, five more than typical discussion of the $\mathrm{C}$ 17 and C-130. Charts for allowable aircraft passes versus soil CBR for these 
aircraft are also included in Appendix B of ETL 02-19. An aircraft pass on a runway is equivalent to a take-off and landing of an aircraft similar in weight to the design aircraft.

Table 1. Aircraft characteristics (ETL 02-19, Table 7).

\begin{tabular}{|l|c|c|c|c|c|c|c|}
\multicolumn{1}{|c|}{ Aircraft } & $\begin{array}{c}\text { Minimum } \\
\text { Weight } \\
\text { (pounds) }\end{array}$ & $\begin{array}{c}\text { Maximum } \\
\text { Weight } \\
\text { (pounds) }\end{array}$ & $\begin{array}{c}\text { Length } \\
\text { (feet) }\end{array}$ & $\begin{array}{c}\text { Wingspa } \\
\text { n (feet) }\end{array}$ & $\begin{array}{c}\text { Runway } \\
\text { Length } \\
\text { (feet) }\end{array}$ & $\begin{array}{c}\text { Runway } \\
\text { Width } \\
\text { (feet) }\end{array}$ & $\begin{array}{c}\text { Taxiway } \\
\text { Width } \\
\text { (feet) }\end{array}$ \\
\hline C-130 Hercules & 69,000 & 175,000 & $\times 98.5$ & 132.6 & 3,500 & 60 & 30 \\
\hline C-141 Starlifter & 144,000 & 345,000 & 168.3 & 160.0 & 6,000 & 88 & 50 \\
\hline C-5 Galaxy & 375,000 & 837,000 & 247.8 & 222.7 & 6,000 & 148 & 75 \\
\hline $\begin{array}{l}\text { C-17 Globemaster } \\
\text { III }\end{array}$ & 279,000 & 585,000 & 174.0 & 169.8 & 3,500 & 80 & 60 \\
\hline KC-10 Extender & 270,000 & 590,000 & 181.6 & 165.3 & 7,000 & 148 & 75 \\
\hline KC-135 Stratotanker & 135,000 & 302,000 & 136.2 & -130.8 & 7,000 & 148 & 75 \\
\hline A-10 Thunderbolt & 28,000 & 51,000 & 53.3 & 57.5 & 10,000 & 150 & 75 \\
\hline F-15 Eagle & 31,700 & 81,000 & 63.8 & 42.8 & 10,000 & 150 & 75 \\
\hline F-16 Fighting Falcon & 17,400 & 37,500 & 49.5 & 32.8 & 10,000 & 150 & 75 \\
\hline
\end{tabular}

\subsection{LZ site planning and considerations}

When planning the layout of an LZ that will be used for extended operations (generally defined as more than 1 year), it is important to address site conditions beyond the safety of the aircraft-related operations. These conditions include land-use compatibility with clear zones, primary surfaces, exclusion areas, and approach-departure surfaces and with existing and future use of the areas that surround the LZ. In planning an LZ, consider the use and zoning of surrounding land for compatibility with aircraft operations. The purpose is to protect the operational capability of the LZ and to prevent incompatible development, thus minimizing health and safety concerns in areas subject to high noise and accident potential resulting from frequent aircraft overflights. The minimum criteria in UFC 3260-01 Chapter 7 establish standards for a safe environment for aircraft and ground operations. For long-term-use LZs, restricting use of available land beyond the minimum distances contained in this chapter is highly recommended. This will protect Air Force operational capability and enhance the potential for future mission expansion. The goal is to provide an LZ environment that affords the greatest margin of safety and compatibility for personnel, equipment, and facilities.

Site considerations include topography, vegetative cover, existing construction, weather elements, wind direction, soil conditions, flood hazard, 
natural and manmade obstructions, adjacent land use, availability of usable airspace, accessibility of roads and utilities, and potential for expansion. Also, consider the effects of ambient lighting for operations with night vision goggles and the potential for encroachment and the effects of noise on the local community.

When siting a training LZ runway within an existing built-up and occupied area, use a $304.8 \mathrm{~m}$ wide (1000 ft wide) exclusion area rather than the $213.5 \mathrm{~m}$ (700 ft) exclusion area used for LZs in unoccupied areas. The $304.8 \mathrm{~m}$ wide ( $1000 \mathrm{ft}$ wide) exclusion zone extends from clear-zone end to clear-zone end, centered on the runway centerline. In addition, the APZ-LZ is widened to $304.8 \mathrm{~m}$ (1000 ft) wide. Built-up and occupied locations are defined as locations where occupied buildings and facilities exist around the potential LZ site that are not related to the LZ mission. Unoccupied locations are where no buildings or facilities exist around the proposed LZ except those that are LZ mission related. The same rules apply for siting future facilities near existing LZs. If the facility and occupants are not related to the LZ mission, then the wider exclusion zone and APZLZ apply.

\subsection{Geometric criteria for runways and overruns}

AFI 13-217 (2007) provides a table with runway minimum lengths and widths, including for several aircraft for peacetime Air Force fixed-wing LZs (Table 2).

For contingency operations, Table 3 through Table 6 provide dimensional criteria for the layout and design of LZ runways, taxiways, aprons, and overruns for C-130 and C-17 aircraft. 
Table 2. Minimum runway criteria for additional aircraft (AFI 13-217, Table 3.1).

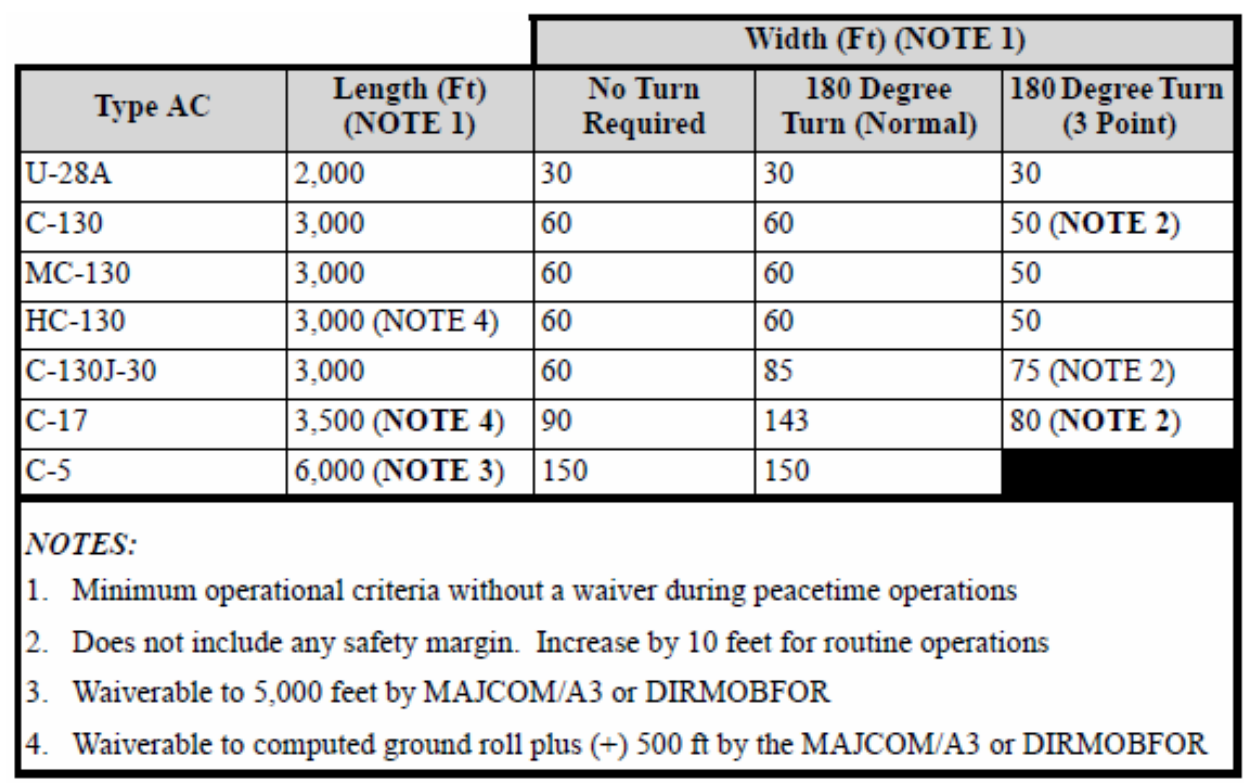

\subsubsection{LZ runway lengths}

Table 3 provides runway lengths for C-17 LZs, and Table 4 provides runway lengths for C-130 LZs. UFC 3-260-01 and ETLs 97-9 and 09-6 provide variations of these tables. For a C-17 LZ located between sea level and $915 \mathrm{~m}$ (3000 ft) pressure altitude, the minimum length requirement for C17 operations is $1067 \mathrm{~m}$ (3500 ft) with $91.5 \mathrm{~m}$ (300 ft) overruns on each end. (Section 4.5.4 of this review discusses overruns.) This length requirement, based on a runway condition rating (RCR) of 20, assumes an ambient temperature of $32.2^{\circ} \mathrm{C}\left(90^{\circ} \mathrm{F}\right)$ and a landing gross weight of $202,756 \mathrm{~kg}$ (447,000 lb). Based on these same temperature and weight assumptions, the runway length will vary with different RCRs. Typically, paved surfaces will have RCRs of 23 dry, 12 wet, and 5 icy. Mat surfaces will have RCRs of 23 dry and 10 wet. A semi-prepared runway with stabilized soil surfaces will have RCRs of 20 dry and 10 wet. Unstabilized soil surfaces will have RCRs of 20 dry and 4 wet. 
Table 3. C-17 runway length (ETL 09-6, Table 1). Note that runway lengths do not include overruns.

\begin{tabular}{|c|c|c|}
\hline \multicolumn{3}{|c|}{$\begin{array}{c}202,756 \text { KG }(447,000 \text { LB }) \text { : NORMAL MAX WEIGHT FOR } \\
\text { SOIL SURFACED LZs }\end{array}$} \\
\hline RCR & $\begin{array}{l}\text { Pressure Altitude } \\
\text { (Meters [Feet]) }\end{array}$ & $\begin{array}{l}\text { Runway Length } \\
\text { (Meters [Feet]) }\end{array}$ \\
\hline \multirow{3}{*}{20} & 0 to $914(3000)$ & $1067(3500)$ \\
\hline & $915(3001)$ to $1829(6000)$ & $1219(4000)$ \\
\hline & $1830(8001)$ to $2134(7000)$ & $1372(4500)$ \\
\hline \multirow{4}{*}{16} & 0 to $609(2000)$ & $1219(4000)$ \\
\hline & $610(2001)$ to $1524(5000)$ & $1372(4500)$ \\
\hline & $1525(5001)$ to $1829(6000)$ & $1524(5000)$ \\
\hline & $1830(6001)$ to $2134(7000)$ & $1676(5500)$ \\
\hline \multirow{4}{*}{12} & 0 to $609(2000)$ & $1372(4500)$ \\
\hline & $610(2001)$ to $1524(5000)$ & $1524(5000)$ \\
\hline & $1525(5001)$ to $1829(6000)$ & $1676(5500)$ \\
\hline & $1830(6001)$ to $2134(7000)$ & $1829(6000)$ \\
\hline \multirow{3}{*}{8} & 0 to $609(2000)$ & $1676(5500)$ \\
\hline & $610(2001)$ to $1219(4000)$ & $1829(6000)$ \\
\hline & $1220(4001)$ to $2134(7000)$ & $1981(6500)$ \\
\hline \multirow{3}{*}{4} & 0 to $609(2000)$ & $2134(7000)$ \\
\hline & $610(2001)$ to $1524(5000)$ & $2286(7500)$ \\
\hline & $1525(5001)$ to $2134(7000)$ & $2438(8000)$ \\
\hline \multicolumn{3}{|c|}{$\begin{array}{l}220,446 \text { KG }(486,000 \text { LB): INCREASED MAX WEIGHT FOR } \\
\text { SOIL SURFACED LZs }\end{array}$} \\
\hline RCR & $\begin{array}{l}\text { Pressure Altitude } \\
\text { (Meters [Feet]) }\end{array}$ & $\begin{array}{l}\text { Runway Length } \\
\text { (Meters [Feet]) }\end{array}$ \\
\hline \multirow{5}{*}{20} & 0 to $914(3000)$ & $1067(3500)$ \\
\hline & $915(3001)$ to $1219(4000)$ & $1219(4000)$ \\
\hline & $1220(4001)$ to $1524(5000)$ & $1372(4500)$ \\
\hline & $1525(5001)$ to $1829(6000)$ & $1524(5000)$ \\
\hline & $1830(6001)$ to $2134(7000)$ & $1676(5500)$ \\
\hline \multirow{5}{*}{16} & 0 to $609(2000)$ & $1219(4000)$ \\
\hline & $610(2001)$ to $914(3000)$ & $1372(4500)$ \\
\hline & $915(3001)$ to $1524(5000)$ & $1524(5000)$ \\
\hline & $1525(5001)$ to $1829(6000)$ & $1676(5500)$ \\
\hline & $1830(6001)$ to $2134(7000)$ & $1829(6000)$ \\
\hline \multicolumn{3}{|c|}{$\begin{array}{l}\text { 220,446 KG (486,000 LB): INCREASED MAX WEIGHT FOR } \\
\text { SOIL SURFACED LZs } \\
\text { (continued) }\end{array}$} \\
\hline \multirow{5}{*}{12} & 0 to $609(2000)$ & $1372(4500)$ \\
\hline & $810(2001)$ to $914(3000)$ & $1524(5000)$ \\
\hline & $915(3001)$ to $1524(5000)$ & $1876(5500)$ \\
\hline & $1525(5001)$ to $1829(6000)$ & $1829(6000)$ \\
\hline & $1830(6001)$ to $2134(7000)$ & $1981(6500)$ \\
\hline \multirow{4}{*}{8} & 0 to $609(2000)$ & $1676(5500)$ \\
\hline & $610(2001)$ to $1219(4000)$ & $1829(6000)$ \\
\hline & $1220(4001)$ to $1524(5000)$ & $1981(6500)$ \\
\hline & $1525(5001)$ to $2134(7000)$ & $2134(7000)$ \\
\hline \multirow{4}{*}{4} & 0 to $609(2000)$ & $2134(7000)$ \\
\hline & $610(2001)$ to $1524(5000)$ & $2286(7500)$ \\
\hline & $1525(5001)$ to $1829(6000)$ & $2438(8000)$ \\
\hline & $1830(6001)$ to $2134(7000)$ & $2591(8500)$ \\
\hline
\end{tabular}




\subsubsection{LZ runway widths}

Table 4 provides the minimum width for LZ runways. The widths of these landing surfaces provide the minimum-width operating surface for the given aircraft.

Table 4. Runways for LZs (UFC 3-260-1, Table 7-2).

\begin{tabular}{|c|c|c|c|c|c|c|}
\hline \multicolumn{7}{|c|}{ Runways for LZs } \\
\hline \multicolumn{2}{|r|}{ Item } & \multicolumn{2}{|l|}{ Paved } & \multicolumn{2}{|c|}{$\begin{array}{l}\text { Semi-Prepared } \\
\text { (Unpaved) }\end{array}$} & \multirow[b]{2}{*}{ Remarks } \\
\hline No. & Description & C-130 & C-17 & C-130 & $\mathrm{C}-17$ & \\
\hline 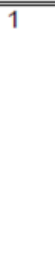 & Length & $\begin{array}{l}\text { Min. } \\
914 \mathrm{~m} \\
(3000 \mathrm{ft})\end{array}$ & $\begin{array}{l}\text { Min. } \\
1067 \mathrm{~m} \\
(3500 \mathrm{ft}) \\
\text { See } \\
\text { Remarks. }\end{array}$ & $\begin{array}{l}\text { Min. } \\
914 \mathrm{~m} \\
(3000 \mathrm{ft})\end{array}$ & $\begin{array}{l}\text { Min. } \\
1067 \mathrm{~m} \\
(3500 \mathrm{ft}) \\
\text { See } \\
\text { Remarks. }\end{array}$ & $\begin{array}{l}\text { See paragraph } 7-6.1 \text { for } \mathrm{LZ} \\
\text { length requirements for the } \\
\mathrm{C}-17 \text {. For lengths less than } \\
1067 \mathrm{~m} \text { ( } 3500 \mathrm{ft}) \text {, an Air Force } \\
\text { MAJCOM Directorate of } \\
\text { Operations waiver is required } \\
\text { prior to initiating flying } \\
\text { operations (see paragraph } \\
7-8 \text { ). }\end{array}$ \\
\hline 2 & Width & $\begin{array}{l}18.5 \mathrm{~m} \\
(60 \mathrm{ft})\end{array}$ & $\begin{array}{l}27.5 \mathrm{~m} \\
(90 \mathrm{ft})\end{array}$ & $\begin{array}{l}18.5 \mathrm{~m} \\
(60 \mathrm{ft})\end{array}$ & $\begin{array}{l}27.5 \mathrm{~m} \\
(90 \mathrm{ft})\end{array}$ & See Note. \\
\hline 3 & $\begin{array}{l}\text { Width of } \\
\text { shoulders }\end{array}$ & \multicolumn{4}{|c|}{ Min. $3 \mathrm{~m}(10 \mathrm{ft})$} & $\begin{array}{l}\text { Remove all tree stumps and } \\
\text { loose rocks in shoulder areas. } \\
\text { Shoulders for paved LZs shall } \\
\text { be paved. Shoulders for semi- } \\
\text { prepared LZs should be } \\
\text { stabilized to prevent erosion } \\
\text { by jet blast. Where adequate } \\
\text { sod cover cannot be } \\
\text { established, the shoulders } \\
\text { should be chemically } \\
\text { stabilized. }\end{array}$ \\
\hline 4 & $\begin{array}{l}\text { Longitudinal } \\
\text { grades of } \\
\text { runway and } \\
\text { shoulders }\end{array}$ & \multicolumn{4}{|c|}{ Max. 3 percent } & $\begin{array}{l}\text { Hold to minimum practicable. } \\
\text { Grades may be both positive } \\
\text { and negative but must not } \\
\text { exceed the limit specified. }\end{array}$ \\
\hline 5 & $\begin{array}{l}\text { Longitudinal } \\
\text { runway grade } \\
\text { change }\end{array}$ & \multicolumn{4}{|c|}{ Max. 1.5 percent per $61 \mathrm{~m} \mathrm{(200} \mathrm{ft)}$} & $\begin{array}{l}\text { Grade changes should be held } \\
\text { to a minimum and should be } \\
\text { gradual. Minimum distance } \\
\text { between grade changes is } \\
61 \mathrm{~m} \text { ( } 200 \mathrm{ft}) \text {. Grade changes } \\
\text { cannot exceed } 1.5 \text { percent } \\
\text { measured at } 61 \mathrm{~m} \text { ( } 200 \mathrm{ft}) \\
\text { intervals. }\end{array}$ \\
\hline 6 & $\begin{array}{l}\text { Transverse } \\
\text { grade of } \\
\text { runway }\end{array}$ & \multicolumn{4}{|c|}{0.5 percent Min. 3.0 percent Max. } & $\begin{array}{l}\text { Transverse grades should } \\
\text { slope down from the runway } \\
\text { centerline. The intent of the } \\
\text { transverse grade limit is to } \\
\text { provide adequate cross slope } \\
\text { to facilitate drainage without } \\
\text { adversely affecting aircraft } \\
\text { operations. }\end{array}$ \\
\hline
\end{tabular}


Table 4 (cont.). Runways for LZs (UFC 3-260-1, Table 7-2).

\begin{tabular}{|c|c|c|c|c|c|c|}
\hline \multicolumn{7}{|c|}{ Runways for LZs } \\
\hline \multicolumn{2}{|r|}{ Item } & \multicolumn{2}{|l|}{ Paved } & \multicolumn{2}{|c|}{$\begin{array}{l}\text { Semi-Prepared } \\
\text { (Unpaved) }\end{array}$} & \multirow[b]{2}{*}{ Remarks } \\
\hline No. & Description & C-130 & C-17 & C-130 & $C-17$ & \\
\hline 7 & $\begin{array}{l}\text { Transverse } \\
\text { grade of } \\
\text { runway } \\
\text { shoulders }\end{array}$ & \multicolumn{4}{|c|}{1.5 percent Min. 5.0 percent Max. } & $\begin{array}{l}\text { Transverse grades should } \\
\text { slope down from the runway } \\
\text { edge. The intent of the } \\
\text { transverse grade limit is to } \\
\text { facilitate drainage. }\end{array}$ \\
\hline 8 & $\begin{array}{l}\text { Width of } \\
\text { graded area }\end{array}$ & \multicolumn{4}{|c|}{$10.5 \mathrm{~m} \mathrm{(35 \textrm {ft } )}$} & $\begin{array}{l}\text { Cut trees flush with the ground } \\
\text { and remove rocks larger than } \\
100 \mathrm{~mm} \text { ( } 4 \text { in) in diameter. } \\
\text { Remove vegetation (excluding } \\
\text { grass) to within } 150 \mathrm{~mm} \text { ( } 6 \text { in) } \\
\text { of the ground. Jet blast may } \\
\text { cause erosion of the graded } \\
\text { area. For paved LZs where } \\
\text { adequate vegetation cannot be } \\
\text { established to prevent erosion, } \\
\text { the graded area can be } \\
\text { covered with a thin } 38 \mathrm{~mm} \text { to } \\
51 \mathrm{~mm} \text { ( } 1.5 \text { in. to } 2.0 \mathrm{in} \text { ) } \\
\text { asphalt layer. }\end{array}$ \\
\hline 9 & $\begin{array}{l}\text { Transverse } \\
\text { grade of } \\
\text { graded area }\end{array}$ & \multicolumn{4}{|c|}{$\begin{array}{l}2.0 \text { percent Min. } \\
5.0 \text { percent Max. }\end{array}$} & $\begin{array}{l}\text { Grades may slope up or down } \\
\text { to provide drainage, but may } \\
\text { not penetrate the primary } \\
\text { surface. }\end{array}$ \\
\hline 10 & $\begin{array}{l}\text { Width of } \\
\text { maintained } \\
\text { area }\end{array}$ & $\begin{array}{l}18.5 \mathrm{~m} \\
(60 \mathrm{ft})\end{array}$ & $\begin{array}{l}21.5 \mathrm{~m} \\
(70 \mathrm{ft})\end{array}$ & $\begin{array}{l}18.5 \mathrm{~m} \\
(60 \mathrm{ft})\end{array}$ & $\begin{array}{l}21.5 \mathrm{~m} \\
(70 \mathrm{ft})\end{array}$ & $\begin{array}{l}\text { Remove obstructions; cut } \\
\text { trees flush with ground. } \\
\text { Remove rocks that project } \\
\text { more than } 150 \mathrm{~mm} \text { ( } 6 \text { in) } \\
\text { above grade. Remove } \\
\text { vegetation (excluding grass) to } \\
\text { within } 150 \mathrm{~mm} \text { ( } 6 \text { in) of the } \\
\text { ground. }\end{array}$ \\
\hline 11 & $\begin{array}{l}\text { Maintained } \\
\text { area: } \\
\text { transverse } \\
\text { grade }\end{array}$ & \multicolumn{4}{|c|}{$\begin{array}{c}\text { Maximum range: }+10.0 \text { percent to }-20.0 \\
\text { percent }\end{array}$} & $\begin{array}{l}\text { Grades may slope up or down } \\
\text { to provide drainage, but may } \\
\text { not exceed }+10.0 \text { percent nor } \\
-20.0 \text { percent slope. }\end{array}$ \\
\hline
\end{tabular}

NOTE: For C-17 LZs without parallel taxiways, turnarounds must be provided at both ends of the runway. Turnarounds for $\mathrm{C}-17$ aircraft should be $55 \mathrm{~m}$ (180 ft) long and $50.5 \mathrm{~m}$ (165 ft) wide (including the overrun/taxiway width), with 45-degree fillets. The aircraft must be positioned within $3 \mathrm{~m}$ (10 ft) of the runway edge prior to initiating this turn. If provided, turnarounds for C-130 aircraft should be at least $23 \mathrm{~m}(75 \mathrm{ft})$ in diameter.

\subsubsection{Operational surface gradient allowances}

Operational surface gradient constraints are based on reverse aircraft operations conducted on hard surfaces. See Table 4, Table 5, and Table 6 for specific allowances.

\subsubsection{LZ shoulders and overruns}

Shoulders and overruns are graded and cleared of obstacles and slope downward away from the operating surface, where practical, to facilitate drainage (See Table 4, Table 5, and Table 6). These tables are also presented in ETL 09-6. 
Table 5. Aprons for LZs (UFC 3-260-01, Table 7-4).

\begin{tabular}{|c|c|c|c|c|c|c|}
\hline \multicolumn{7}{|c|}{ Aprons for LZs } \\
\hline \multirow{2}{*}{\multicolumn{2}{|c|}{\begin{tabular}{|l|l|}
\multicolumn{2}{|c|}{ Item } \\
No. & Description \\
\end{tabular}}} & \multicolumn{2}{|c|}{ Paved } & \multicolumn{2}{|c|}{$\begin{array}{l}\text { Semi-Prepared } \\
\text { (Unpaved) }\end{array}$} & \multirow[b]{2}{*}{ Remarks } \\
\hline & & $C-130$ & C-17 & $C-130$ & C-17 & \\
\hline \multirow[b]{2}{*}{2} & Apron size & \multicolumn{2}{|c|}{ See Remarks. } & \multicolumn{2}{|c|}{ See Note. } & $\begin{array}{l}\text { Sized to accommodate mission. } \\
\text { Maximum visibility must be } \\
\text { maintained at all times. As a } \\
\text { minimum, the pilot must be able to } \\
\text { clearly see all parked aircraft when } \\
\text { taxiing. } \\
\text { On paved aprons, clearance } \\
\text { between wing tips of parked } \\
\text { aircraft should be minimum } 7.5 \mathrm{~m} \\
\text { ( } 25 \mathrm{ft}) \text {. } \\
\text { Clearance between wing tips of } \\
\text { taxiing aircraft and parked aircraft } \\
\text { should be minimum } 7.5 \mathrm{~m}(25 \mathrm{ft}) \\
\text { for paved aprons and } 15 \mathrm{~m}(50 \mathrm{ft}) \\
\text { for semi-prepared aprons. }\end{array}$ \\
\hline & \begin{tabular}{|l|} 
Apron grades \\
in the \\
direction of \\
drainage
\end{tabular} & \multicolumn{4}{|c|}{1.5 to 3.0 percent } & \\
\hline 3 & $\begin{array}{l}\text { Width of } \\
\text { apron } \\
\text { shoulder }\end{array}$ & \multicolumn{4}{|c|}{$3 \mathrm{~m}(10 \mathrm{ft})$} & $\begin{array}{l}\text { Apron shoulders for paved LZs } \\
\text { should be paved. Shoulders for } \\
\text { semi-prepared LZs should be } \\
\text { stabilized to prevent erosion by jet } \\
\text { blast. Where adequate sod cover } \\
\text { cannot be established, the } \\
\text { shoulders should be chemically } \\
\text { stabilized. }\end{array}$ \\
\hline 4 & $\begin{array}{l}\text { Transverse } \\
\text { grade of } \\
\text { shoulder } \\
\text { away from the } \\
\text { apron edge }\end{array}$ & \multicolumn{4}{|c|}{1.5 to 5.0 percent } & $\begin{array}{l}\text { Apron shoulder should be graded } \\
\text { to carry storm water away from the } \\
\text { apron. In shoulder areas, remove } \\
\text { all tree stumps and loose rocks. }\end{array}$ \\
\hline 5 & $\begin{array}{l}\text { Runway } \\
\text { clearance }\end{array}$ & $\begin{array}{l}76 \mathrm{~m} \\
(250 \mathrm{ft})\end{array}$ & $\begin{array}{l}85.5 \mathrm{~m} \\
(280 \mathrm{ft})\end{array}$ & $\begin{array}{l}76 \mathrm{~m} \\
(250 \mathrm{ft})\end{array}$ & $\begin{array}{l}85.5 \mathrm{~m} \\
(280 \mathrm{ft})\end{array}$ & $\begin{array}{l}\text { Measured from the runway } \\
\text { centerline to the near edge of the } \\
\text { parking apron. Aprons may be } \\
\text { contiguous with the runway, but } \\
\text { parked aircraft and vehicles must } \\
\text { be behind this line. }\end{array}$ \\
\hline 6 & $\begin{array}{l}\text { Clearance } \\
\text { from edge of } \\
\text { apron to fixed } \\
\text { or mobile } \\
\text { obstacles }\end{array}$ & $\begin{array}{l}26 \mathrm{~m} \\
(85 \mathrm{ft})\end{array}$ & $\begin{array}{l}30.5 \mathrm{~m} \\
(100 \mathrm{ft})\end{array}$ & $\begin{array}{l}26 \mathrm{~m} \\
(85 \mathrm{ft})\end{array}$ & $\begin{array}{l}30.5 \mathrm{~m} \\
(100 \mathrm{ft})\end{array}$ & $\begin{array}{l}\text { Measured from the outer edge of } \\
\text { the apron to obstacle clearance } \\
\text { line. Remove rocks that project } \\
\text { more than } 150 \mathrm{~mm} \text { ( } 6 \text { in) above } \\
\text { grade. Cut tree stumps, brush, and } \\
\text { other vegetation (excluding grass) } \\
\text { to within } \\
150 \mathrm{~mm} \text { (6 in) of the ground. }\end{array}$ \\
\hline 7 & $\begin{array}{l}\text { Apron clear } \\
\text { area grade }\end{array}$ & \multicolumn{4}{|c|}{$\begin{array}{c}\text { Maximum range: }+10.0 \text { percent to } \\
-5.0 \text { percent }\end{array}$} & $\begin{array}{l}\text { Grades may slope up or down to } \\
\text { provide drainage, but may not } \\
\text { exceed a }+10 \text { percent nor } \\
-5 \text { percent slope. Centerline of } \\
\text { drainage ditches must be } \\
\text { established away from apron } \\
\text { shoulders to prevent water from } \\
\text { backing up onto the shoulder area. }\end{array}$ \\
\hline
\end{tabular}

NOTE: To eliminate the potential for FOD created by jet blast to parked and taxiing aircraft, individual parking aprons should be provided for each C-17 aircraft on semi-prepared LZs (other than AM-2 mat surfaced). Each apron should be a minimum of $61 \mathrm{~m}$ (200 ft) wide and $68.5 \mathrm{~m}(225 \mathrm{ft})$ long.

Topography, mission, and obstructions determine the location and spacing between multiple aprons, but the aprons shall not be located less than $152.5 \mathrm{~m}$ ( $500 \mathrm{ft}$ ) apart. All loose material must be stabilized or removed before the aprons can be operational. 
Table 6. Overruns for LZs (UFC 3-260-01, Table 7-5).

\begin{tabular}{|c|c|c|c|c|c|c|}
\hline \multicolumn{7}{|c|}{ Overruns for LZs } \\
\hline \multirow{2}{*}{\multicolumn{2}{|c|}{$\begin{array}{c}\text { Item } \\
\text { No. } \mid \text { Description| }\end{array}$}} & \multicolumn{2}{|c|}{ Paved } & \multicolumn{2}{|c|}{$\begin{array}{l}\text { Semi-Prepared } \\
\text { (Unpaved) }\end{array}$} & \multirow[b]{2}{*}{ Remarks } \\
\hline & & $\mathrm{C}-130$ & $\mathrm{C}-17$ & C-130 & $\mathrm{C}-17$ & \\
\hline 1 & $\begin{array}{l}\text { Overrun } \\
\text { length }\end{array}$ & \multicolumn{4}{|c|}{$91.5 \mathrm{~m}(300 \mathrm{ft})$} & $\begin{array}{l}\text { The overruns must be } \\
\text { constructed to the same } \\
\text { standards as the runway. } \\
\text { Overruns for mat surfaced } \\
\text { runways must also be mat. }\end{array}$ \\
\hline 2 & Overrun width & $\begin{array}{l}18.5 \mathrm{~m} \\
(60 \mathrm{ft})\end{array}$ & $\begin{array}{r}27.5 \mathrm{~m} \\
(90 \mathrm{ft})\end{array}$ & $\begin{array}{r}18.5 \mathrm{~m} \\
(60 \mathrm{ft})\end{array}$ & $\begin{array}{l}27.5 \mathrm{~m} \\
(90 \mathrm{ft})\end{array}$ & \\
\hline 3 & $\begin{array}{l}\text { Longitudinal } \\
\text { grade of } \\
\text { overruns }\end{array}$ & \multicolumn{4}{|c|}{ Maximum 3 percent } & \\
\hline 4 & $\begin{array}{l}\text { Transverse } \\
\text { grade of } \\
\text { overruns }\end{array}$ & \multicolumn{4}{|c|}{$\begin{array}{l}0.5 \text { percent min. } \\
3.0 \text { percent max. }\end{array}$} & $\begin{array}{l}\text { Grades should slope } \\
\text { downward from overrun } \\
\text { centerline. }\end{array}$ \\
\hline 5 & $\begin{array}{l}\text { Width of } \\
\text { overrun } \\
\text { shoulder }\end{array}$ & \multicolumn{4}{|c|}{$3 \mathrm{~m}(10 \mathrm{ft})$} & $\begin{array}{l}\text { Overrun shoulders for paved } \\
\text { LZs should be paved. } \\
\text { Shoulders for semi-prepared } \\
\text { LZs should be stabilized to } \\
\text { prevent erosion by jet blast. } \\
\text { Where adequate sod cover } \\
\text { cannot be established, the } \\
\text { shoulders should be } \\
\text { chemically stabilized. }\end{array}$ \\
\hline 6 & $\begin{array}{l}\text { Transverse } \\
\text { grade of } \\
\text { overrun } \\
\text { shoulders }\end{array}$ & \multicolumn{4}{|c|}{$\begin{array}{l}1.5 \text { percent min. } \\
5.0 \text { percent max. }\end{array}$} & $\begin{array}{l}\text { Transverse grades should } \\
\text { slope down from the overrun } \\
\text { edge. The intent of the } \\
\text { transverse grade limit is to } \\
\text { facilitate drainage. }\end{array}$ \\
\hline
\end{tabular}

\subsubsection{Turnarounds}

For C-17 LZs without parallel taxiways, there must be turnarounds at both ends of the runway. In other cases, turnarounds may be on overruns or taxiways, depending on mission or terrain requirements. The shoulder, structural, gradient, and clearance requirements for a turnaround are the same as those for the overrun or taxiway area where the turnaround is constructed. Turnarounds for C-130 aircraft should be at least $23 \mathrm{~m}$ (75 ft) in diameter. Turnarounds for C-17 aircraft should be $55 \mathrm{~m}$ (180 ft) long and $50.5 \mathrm{~m}$ (165 ft) wide (including the overrun and taxiway width) with $45^{\circ}$ fillets. The aircraft landing gear must be positioned within $3 \mathrm{~m}$ (10 ft) of the runway edge prior to initiating this turn.

\subsubsection{Imaginary surfaces and land-use control areas}

Minimum requirements for clear zones, imaginary surfaces, and APZ-LZs and exclusion areas must be established to provide a reasonable level of safety for LZs. These criteria are provided in Table 7, Table 8, and Table 9, respectively. Figure 1 through Figure 5 show these imaginary surfaces for the Air Force and Army. These figures are also presented in ETL 09-6. 
Table 7. Runway end clear zones for LZs (UFC 3-260-01, Table 7-6).

\begin{tabular}{|c|c|c|c|c|c|c|}
\hline \multicolumn{7}{|c|}{ Runway End Clear Zone for LZs } \\
\hline \multicolumn{2}{|r|}{ Item } & \multicolumn{2}{|c|}{ Paved } & \multicolumn{2}{|c|}{$\begin{array}{c}\text { Semi-Prepared } \\
\text { (Unpaved) }\end{array}$} & \multirow[b]{2}{*}{ Remarks } \\
\hline No & Description & C-130 & C-17 & C-130 & C-17 & \\
\hline 1 & Length & \multicolumn{4}{|c|}{$152.5 \mathrm{~m}(500 \mathrm{ft})$} & $\begin{array}{l}\text { Measured along the extended } \\
\text { runway centerline; begins at the } \\
\text { runway threshold. }\end{array}$ \\
\hline 2 & $\begin{array}{l}\text { Width at inner } \\
\text { edge }\end{array}$ & $\begin{array}{l}82.5 \mathrm{~m} \\
(270 \mathrm{ft})\end{array}$ & $\begin{array}{l}98 \mathrm{~m} \\
(320 \mathrm{ft})\end{array}$ & $\begin{array}{c}82.5 \\
(270 \mathrm{ft})\end{array}$ & $\begin{array}{c}98 \mathrm{~m} \\
(320 \mathrm{ft})\end{array}$ & \\
\hline 3 & $\begin{array}{l}\text { Width at outer } \\
\text { edge }\end{array}$ & \multicolumn{4}{|c|}{$152.5 \mathrm{~m} \mathrm{(500 \textrm {ft } )}$} & \\
\hline 4 & $\begin{array}{l}\text { Longitudinal } \\
\text { and } \\
\text { transverse } \\
\text { grade of } \\
\text { surface }\end{array}$ & \multicolumn{4}{|c|}{ Maximum 5.0 percent } & $\begin{array}{l}\text { Grades are exclusive for clear zone } \\
\text { and are not part of the overrun but } \\
\text { are shaped into the overrun grade. } \\
\text { Grades may slope up or down to } \\
\text { provide drainage. Exception: } \\
\text { Essential drainage ditches may be } \\
\text { sloped up to } 10 \text { percent in clear } \\
\text { zones. Do not locate these ditches } \\
\text { within } 23 \mathrm{~m}(75 \mathrm{ft} \text { ) of a C- } 130 \\
\text { runway centerline or within } 27.5 \mathrm{~m} \\
\text { ( } 90 \mathrm{ft} \text { ) of a C-17 runway centerline. } \\
\text { Such ditches should be essentially } \\
\text { parallel with the runway. Remove or } \\
\text { embed rocks larger than } 100 \mathrm{~mm} \\
(4 \text { in) in diameter. Cut tree stumps, } \\
\text { brush, and other vegetation } \\
\text { (excluding grass) to within } 150 \mathrm{~mm} \\
(6 \text { in) of the ground. }\end{array}$ \\
\hline
\end{tabular}

Table 8. Imaginary surfaces for LZs (UFC 3-260-1, Table 7-7).

\begin{tabular}{|c|c|c|c|c|c|c|}
\hline \multicolumn{7}{|c|}{ Imaginary Surfaces for LZs } \\
\hline \multicolumn{2}{|r|}{ Item } & \multicolumn{2}{|c|}{ Paved } & \multicolumn{2}{|c|}{$\begin{array}{c}\text { Semi-Prepared } \\
\text { (Unpaved) }\end{array}$} & \multirow[b]{2}{*}{ Remarks } \\
\hline No. & Description & C-130 & C-17 & C-130 & C-17 & \\
\hline 1 & $\begin{array}{l}\text { Primary } \\
\text { surface } \\
\text { length }\end{array}$ & \multicolumn{4}{|c|}{ Runway length plus $305 \mathrm{~m}(1,000 \mathrm{ft})$} & $\begin{array}{l}\text { Centered on the runway } \\
\text { (includes lengths of clear } \\
\text { zones) }\end{array}$ \\
\hline 2 & $\begin{array}{l}\text { Primary } \\
\text { surface width }\end{array}$ & $\begin{array}{l}45.5 \mathrm{~m} \\
(150 \mathrm{ft})\end{array}$ & $\begin{array}{l}55 \mathrm{~m} \\
(180 \mathrm{ft})\end{array}$ & $\begin{array}{l}45.5 \mathrm{~m} \\
(150 \mathrm{ft})\end{array}$ & $\begin{array}{l}55 \mathrm{~m} \\
(180 \mathrm{ft})\end{array}$ & Centered on the runway \\
\hline 3 & $\begin{array}{l}\text { Primary } \\
\text { surface } \\
\text { elevation }\end{array}$ & \multicolumn{4}{|c|}{ See Remarks } & $\begin{array}{l}\text { The elevation of the primary } \\
\text { surface is the same as the } \\
\text { elevation of the nearest point } \\
\text { on the runway centerline, or } \\
\text { extended runway centerline. }\end{array}$ \\
\hline 4 & $\begin{array}{l}\text { Approach- } \\
\text { departure } \\
\text { clearance } \\
\text { surface -- } \\
\text { inner edge }\end{array}$ & \multicolumn{4}{|c|}{$\begin{array}{l}152.5 \mathrm{~m} \\
(500 \mathrm{ft})\end{array}$} & Measured from runway end \\
\hline 5 & $\begin{array}{l}\text { Width at inner } \\
\text { edge }\end{array}$ & \multicolumn{4}{|c|}{$\begin{array}{l}152.5 \mathrm{~m} \\
(500 \mathrm{ft})\end{array}$} & \\
\hline 6 & Slope & $35 \mathrm{H}: 1 \mathrm{~V}$ & $20 \mathrm{H}: 1 \mathrm{~V}$ & $35 \mathrm{H}: 1 \mathrm{~V}$ & $20 \mathrm{H}: 1 \mathrm{~V}$ & $\begin{array}{l}\text { Remains constant } \\
\text { throughout length }\end{array}$ \\
\hline 7 & Slope length & \multicolumn{4}{|c|}{$\begin{array}{l}\text { Minimum } 3200 \mathrm{~m} \\
\qquad(10,500 \mathrm{ft})\end{array}$} & $\begin{array}{l}\text { The desired slope length is } \\
9733 \mathrm{~m}(32,000 \mathrm{ft}) \text {. }\end{array}$ \\
\hline 8 & $\begin{array}{l}\text { Width at outer } \\
\text { edge }\end{array}$ & \multicolumn{4}{|c|}{$\begin{array}{l}762 \mathrm{~m}(2,500 \mathrm{ft}) \text { at } 3200 \mathrm{~m}(10,500 \mathrm{ft}) \\
\text { from inner edge }\end{array}$} & $\begin{array}{l}\text { Width of approach-departure } \\
\text { clearance surface is } \\
\text { constant from } 3200 \mathrm{~m} \\
\text { (10,500 ft) to } 9753 \mathrm{~m}(32,000 \\
\text { ft) from the inner edge. }\end{array}$ \\
\hline
\end{tabular}


Table 9. APZs and exclusion areas for LZs (UFC 3-260-1, Table 7-8).

\begin{tabular}{|c|c|c|c|c|c|c|}
\hline \multicolumn{7}{|c|}{ APZs and Exelusion Areas for LZs } \\
\hline \multicolumn{2}{|r|}{ Item } & \multicolumn{2}{|c|}{ Paved } & \multicolumn{2}{|c|}{$\begin{array}{l}\text { Semi-Prepared } \\
\text { (Unpaved) }\end{array}$} & \multirow[b]{2}{*}{ Remarks } \\
\hline No. & Description & C- 130 & C-17 & C-130 & C-17 & \\
\hline 1 & APZ-LZ length & & 762 & $2500 \mathrm{ft})$ & & $\begin{array}{l}\text { Where possible, limit these actions } \\
\text { within the APZ-LZ: } \\
\text { - Actions that release any } \\
\text { substances into the air that } \\
\text { would impair visibility or } \\
\text { otherwise interfere with } \\
\text { operating aircraft, such as } \\
\text { steam, dust, and smoke } \\
\text { - Actions that produce electrical } \\
\text { emissions that would interfere } \\
\text { with aircraft and/or } \\
\text { communications or navigational } \\
\text { aid systems } \\
\text { - Actions that produce light } \\
\text { emissions, direct or indirect } \\
\text { (reflective), that might interfere } \\
\text { with pilot vision }\end{array}$ \\
\hline 2 & APZ-LZ width & $\begin{array}{l}\text { Unoc } \\
\text { Occur }\end{array}$ & upied $A$ & $\begin{array}{l}152.5 \mathrm{~m} \\
\text { n-Up Are } \\
0 \mathrm{ft})\end{array}$ & $300 \mathrm{ft})$ & $\begin{array}{l}\text { - Items that unnecessarily attract } \\
\text { birds or waterfowl, such as } \\
\text { sanitary landfills, feeding } \\
\text { stations, or certain types of } \\
\text { crops or vegetation. } \\
\text { - Explosive facilities or activities } \\
\text { - Troop concentrations, such as } \\
\text { housing areas, dining or medical } \\
\text { facilities, and recreational fields } \\
\text { that include spectators } \\
\text { For cases where a training LZ may } \\
\text { be sited near permanently occupied } \\
\text { facilities or where new facilities may } \\
\text { be sited near an LZ, use a } 305-m \text { - } \\
\text { wide }(1,000 \text {-ft-wide) APZ-LZ. See } \\
\text { section } 7-5 \text { for all necessary } \\
\text { modifications and considerations. }\end{array}$ \\
\hline 3 & Exclusion area & Unoce & $\begin{array}{l}\text { upied Ar } \\
\text { Occupie } \\
\text { Area: } 30\end{array}$ & $\begin{array}{l}213.5 \mathrm{~m} \\
\text { nd Built- } \\
\text { n (1000 }\end{array}$ & $00 \mathrm{ft})$ & 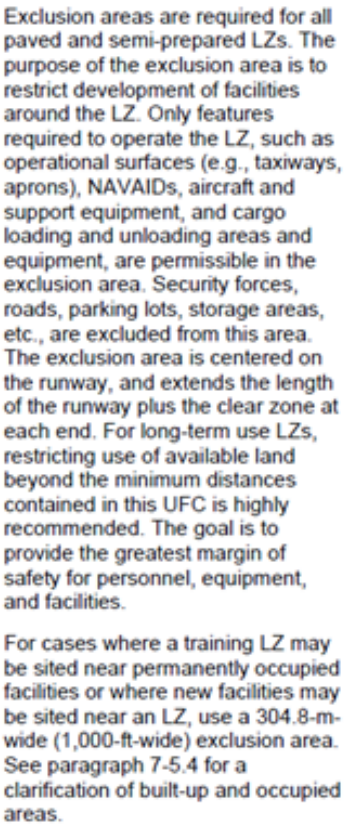 \\
\hline
\end{tabular}


Figure 1. LZ primary surface end details (UFC 3-260-01, Fig. 7-1).
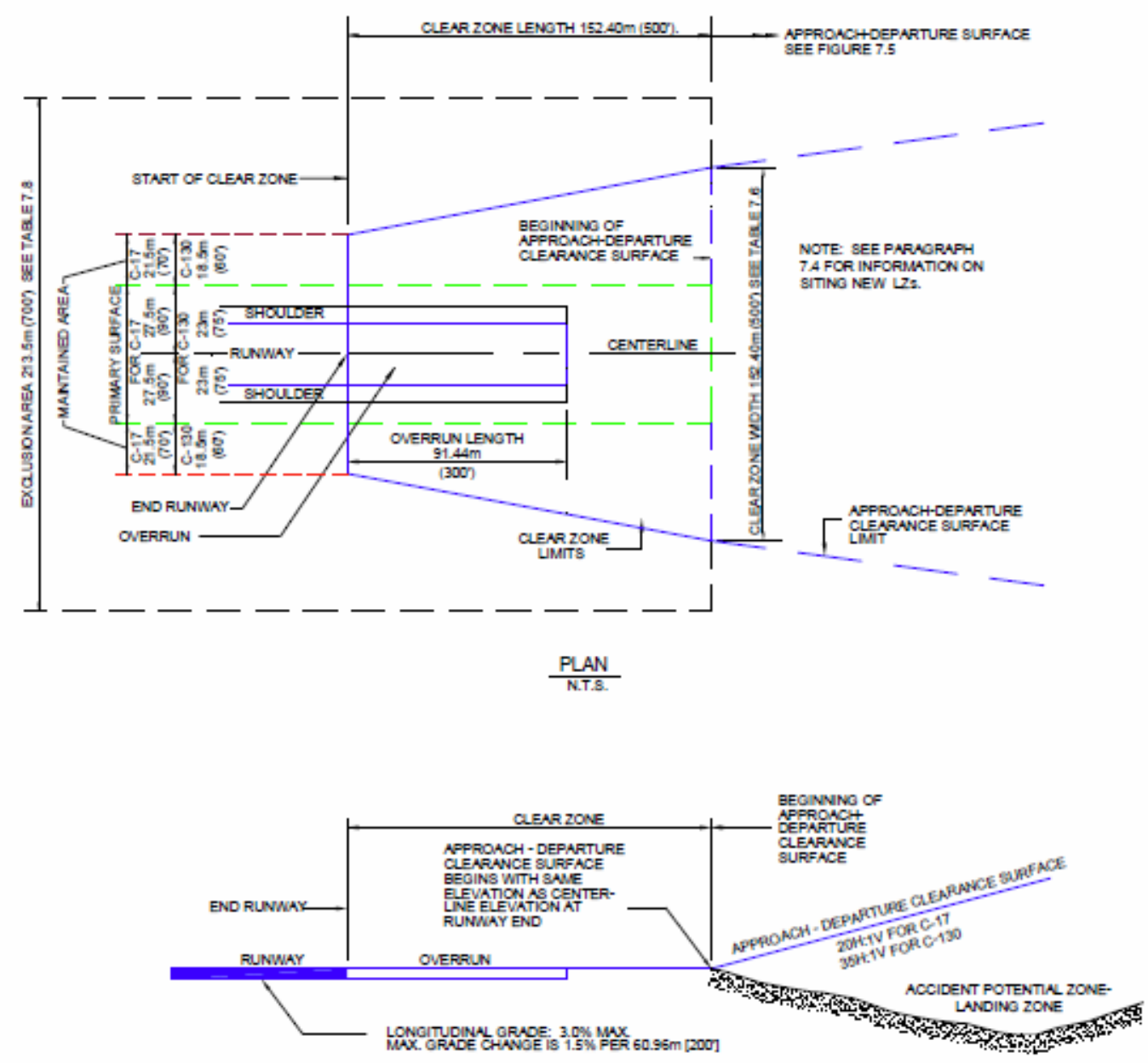
Figure 2. LZ with contiguous aprons and turnarounds (UFC 3-260-01, Fig. 7-2).

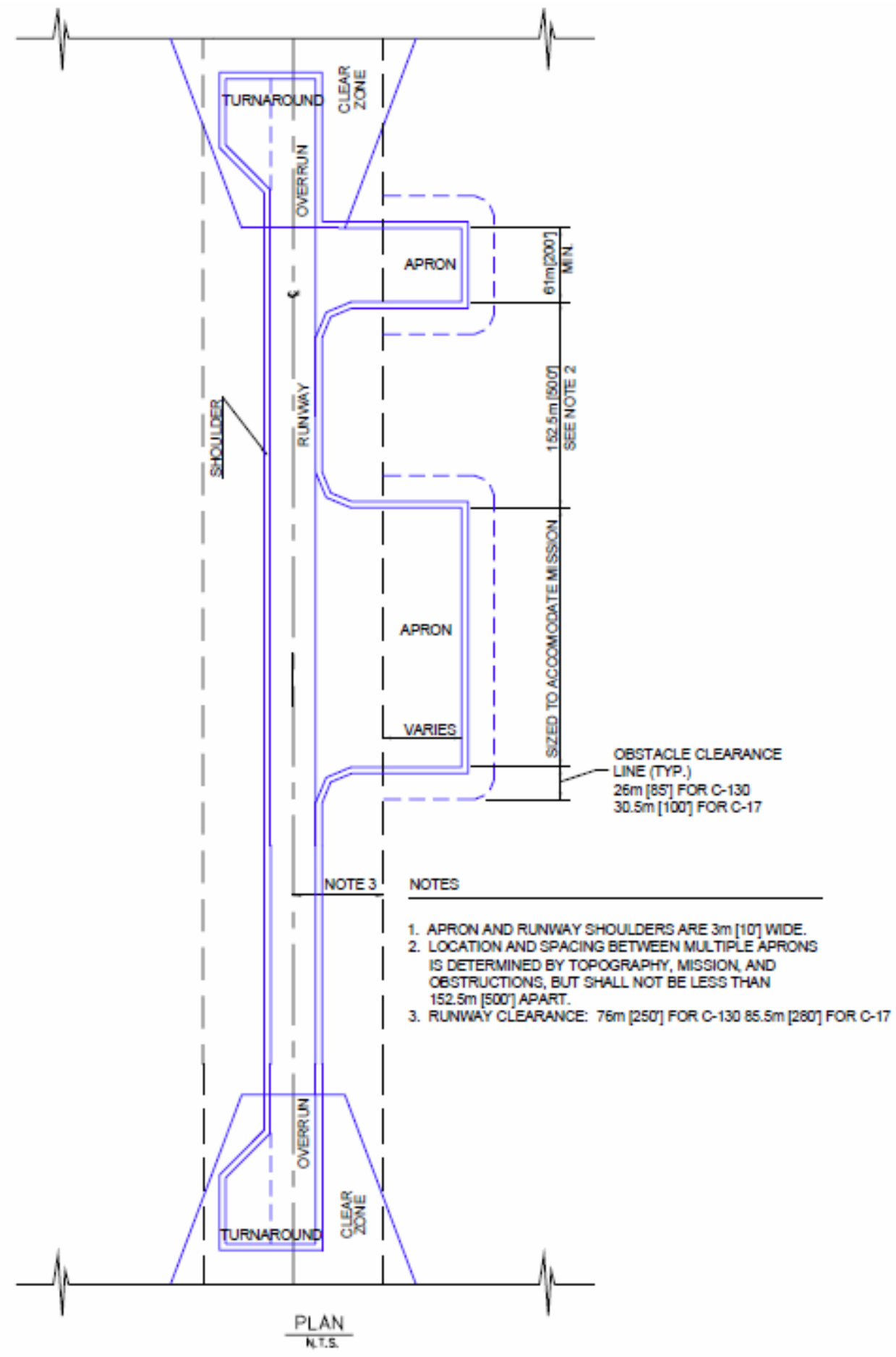


Figure 3. LZ apron layout details (UFS 3-260-01, Fig. 7-4).

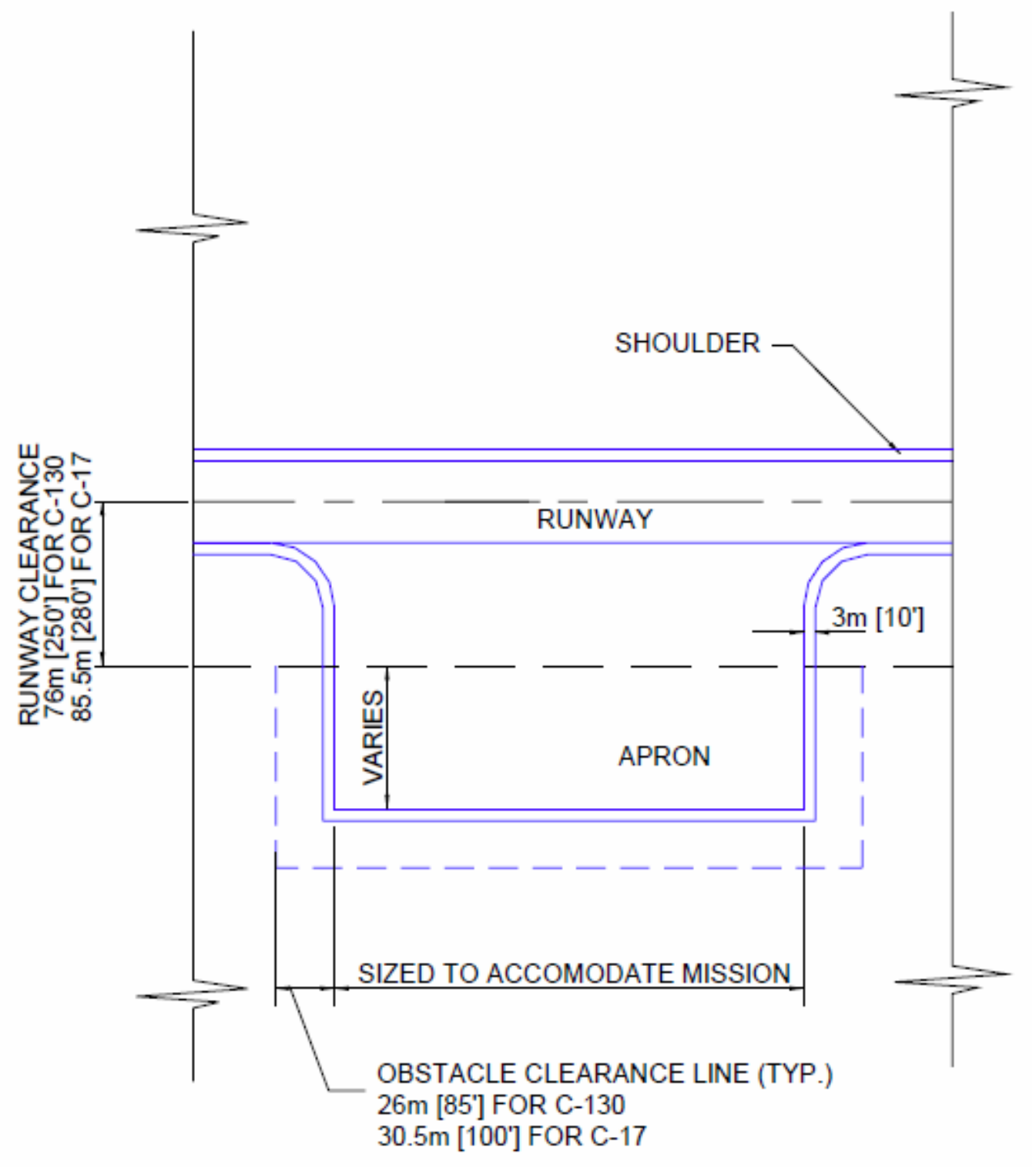

$$
\frac{\text { PLAN }}{\text { N.T.S. }}
$$


Figure 4. LZ runway imaginary surfaces (UFC 3-260-01, Fig. 7-5).
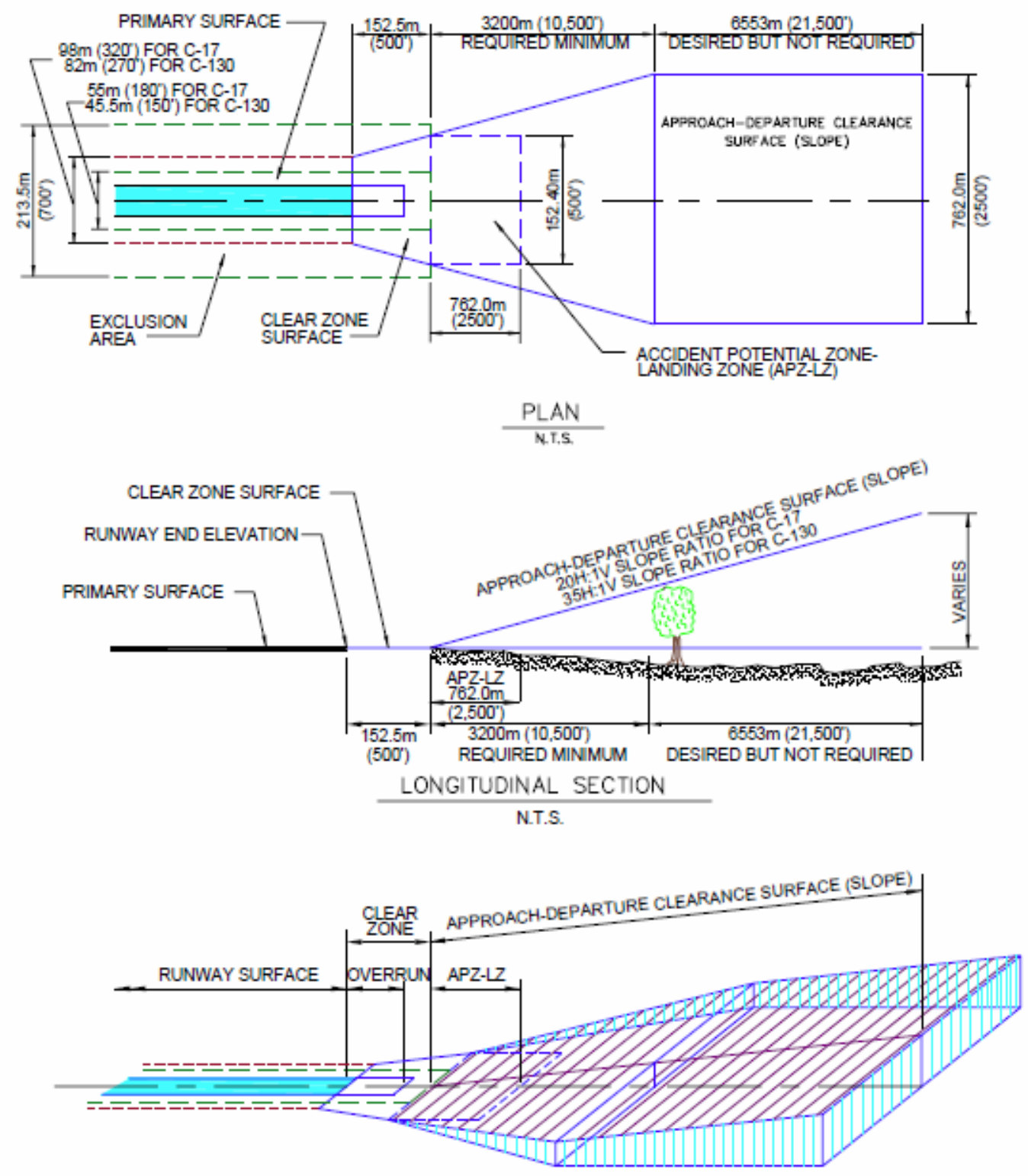

ISOMETRIC VIEW 
Figure 5. LZ runway and apron sections (UFC 3-260-01, Fig. 7-6).

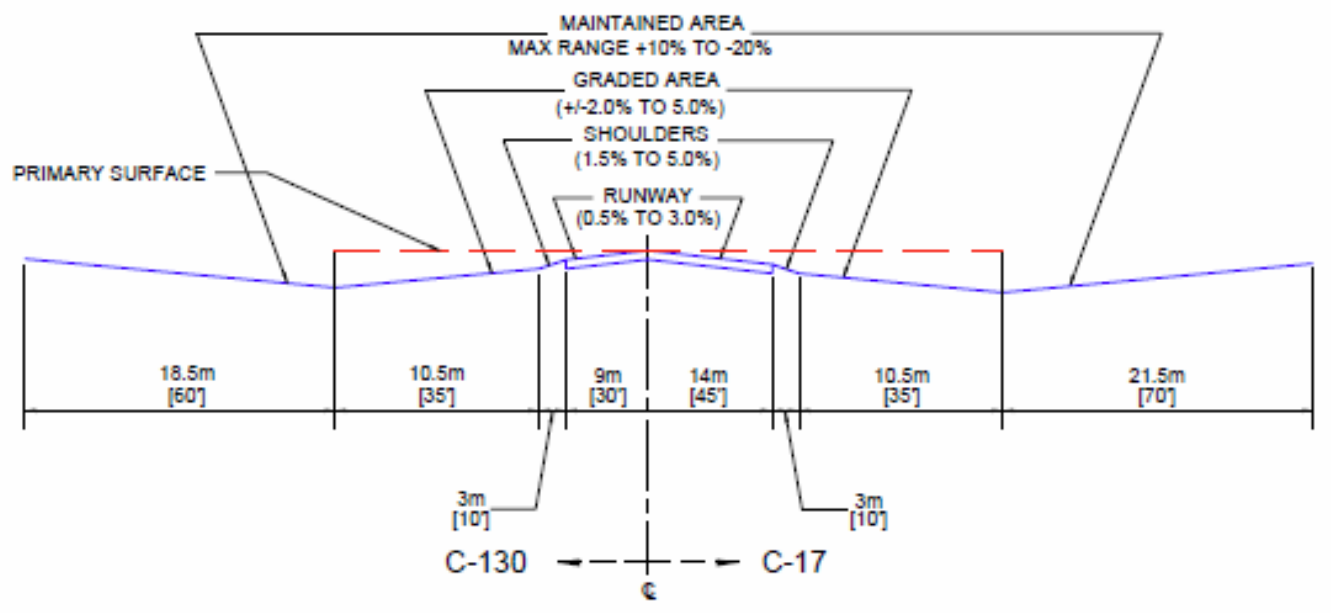

RUNWAY CROSS SECTION

N.T.S.

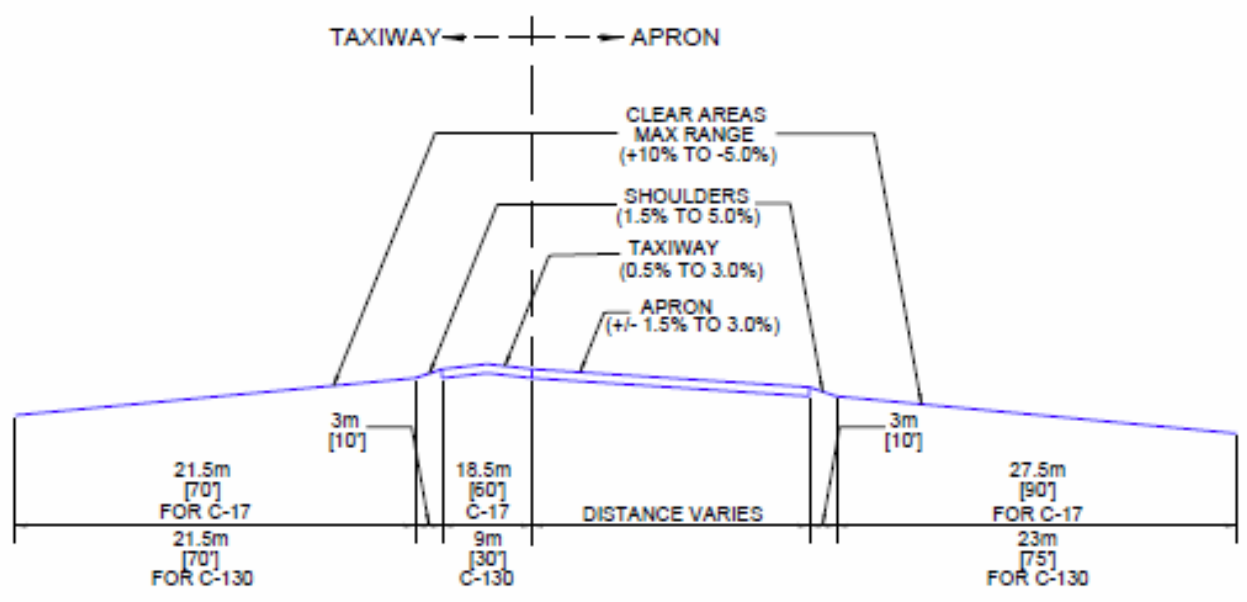

TAXIWAYIAPRON CROSS SECTION

N.I.S.

NOTE:

A $+1-1.5 \%$ TO $5.0 \%$ GRADE MEANS THE SURFACE WILL BE SLOPED, EITHER POSITIVELY BETWEEN + 1.5\% AND +5.0\% OR NEGATIVELY BETWEEN $-1.5 \%$ AND $-5.0 \%$, BUT NOT LEVEL.

\subsection{Surface strength}

FM 5-430-00-2 states that for expedient-surfaced airfields, the in-place soil strength determines the number of aircraft passes. The current Air Force measure for soil strength is the CBR. The current evaluation proce- 
dures for CBR include the Dynamic Cone Penetrometer, which is the preferred method of obtaining field CBR; the Airfield Cone Penetrometer; the Electronic Cone Penetrometer; and the Unified Soil Classification System. Correlation with soil type, though the quickest test, is also the least accurate.

\subsubsection{Unsurfaced design}

For unsurfaced design for C-17 operations, the design criterion in ETL 979 consists of the determination of a minimum surface CBR value and a minimum thickness of material equal to or greater than the minimum surface CBR over a lower-strength material. The existing soil conditions must meet both the surface $\mathrm{CBR}$ requirement and the thickness requirements.

To determine if the surface CBR is sufficient to sustain the design traffic, enter Figure 6 with the required number of aircraft passes. Proceed vertically until the pass level intersects the appropriate design gross weight of the aircraft. Finally, trace a horizontal line from this intersection to the required subgrade CBR value. The CBR obtained is the surface soil strength required to support the design aircraft load at the required pass level. If the CBR obtained from Figure 6 is greater than the in-place subgrade CBR determined from the preliminary site investigation, the airfield will require structural improvement to support mission requirements.

Figure 6. Unsurfaced strength requirement for the C-17 aircraft (ETL 97-9, Fig. 4.1).

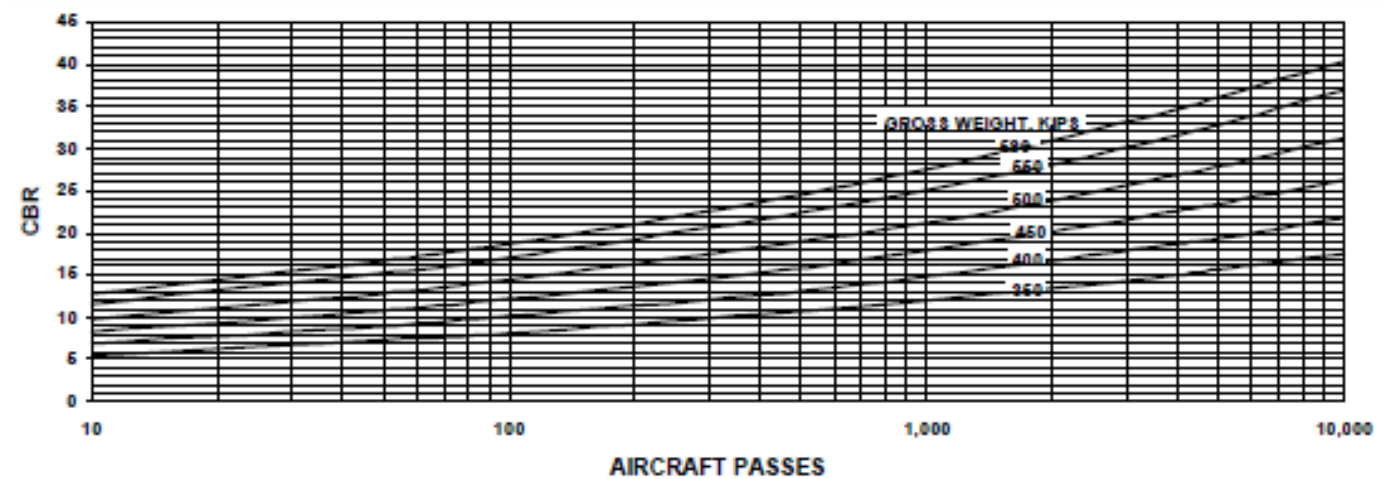

ETL 02-19 (2002) presents an updated version of this chart (Figure 7) and includes soil surface strength requirement charts for the A-10, C-5A, C130H, C-141, KC-10, and KC-135 aircraft. 
Figure 7. Soil surface strength requirements for the C-17 aircraft (ETL 02-19, Fig. B-5).

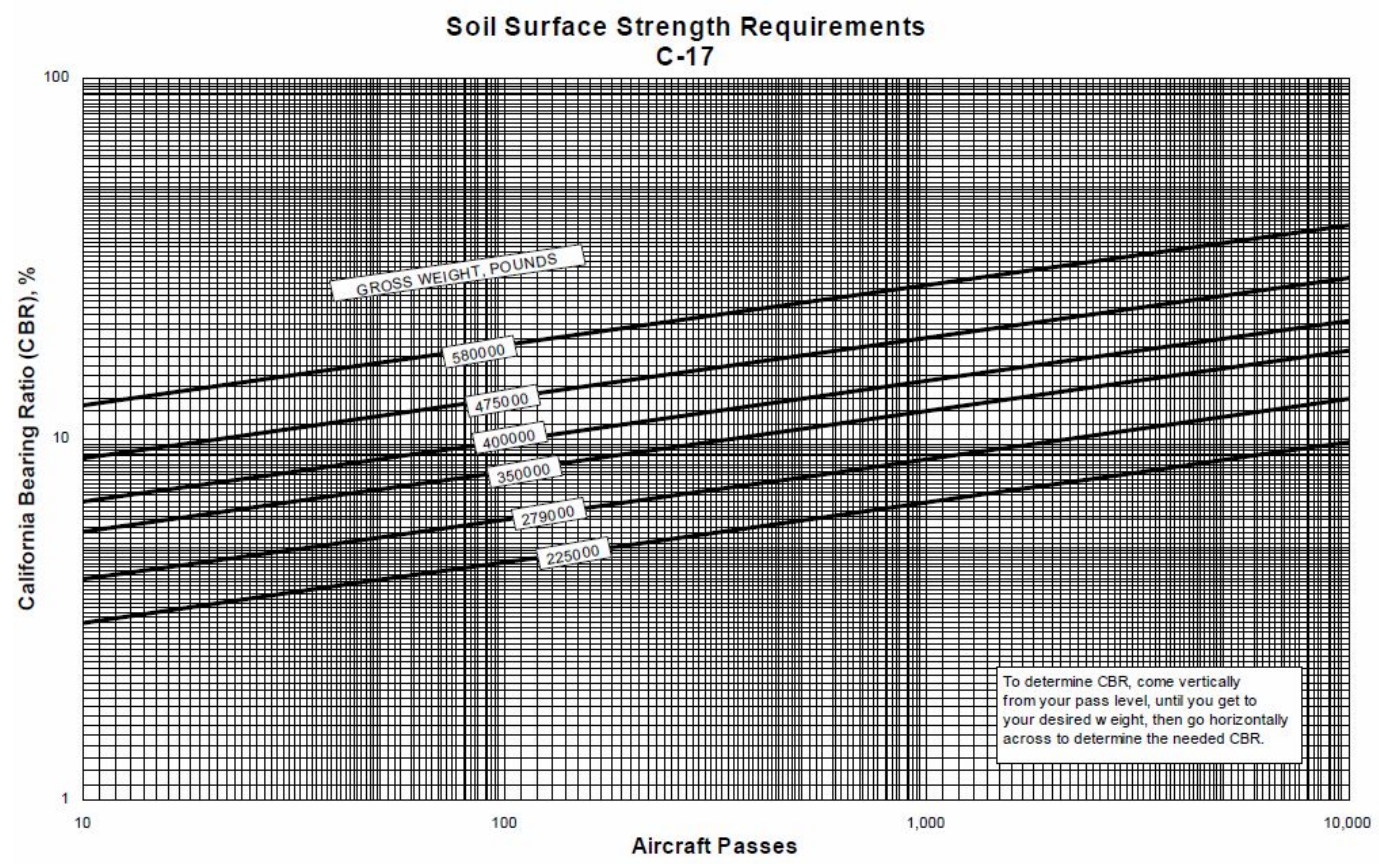

Next, determine the minimum thickness of the required CBR from Figure 8. Enter Figure 8 at the top with the in-place subgrade CBR, and draw a vertical line down until it intersects the design gross weight of the aircraft. Then, draw a horizontal line from this point until it intersects the required design passes. Finally, draw a vertical line down from the required pass level until it intersects the required thickness. This thickness is the required thickness in inches of a material of the minimum surface CBR determined from Figure 6 necessary to support mission requirements. If the in-place subgrade CBR is equal to or greater than the minimum subgrade CBR determined from Figure 6 and the preliminary site investigation revealed that the depth of the in-place subgrade CBR is equal to or greater than the thickness determined from Figure 8, then the airfield is structurally adequate to support the design traffic. If a weaker soil layer is encountered at some depth below the surface soil layer, the thickness of material required to protect the weaker soil layer should be checked using Figure 8. Enter Figure 8 with the weak layer's CBR rather than the surface layer's $\mathrm{CBR}$. If the thickness of the surface layer is not sufficient to protect the underlying weak layer, the airfield requires structural improvement to withstand the design traffic. 
Figure 8. Aggregate or select fill surface thickness requirements for the $\mathrm{C}-17$ aircraft (ETL 97-9, Fig. 4.2).

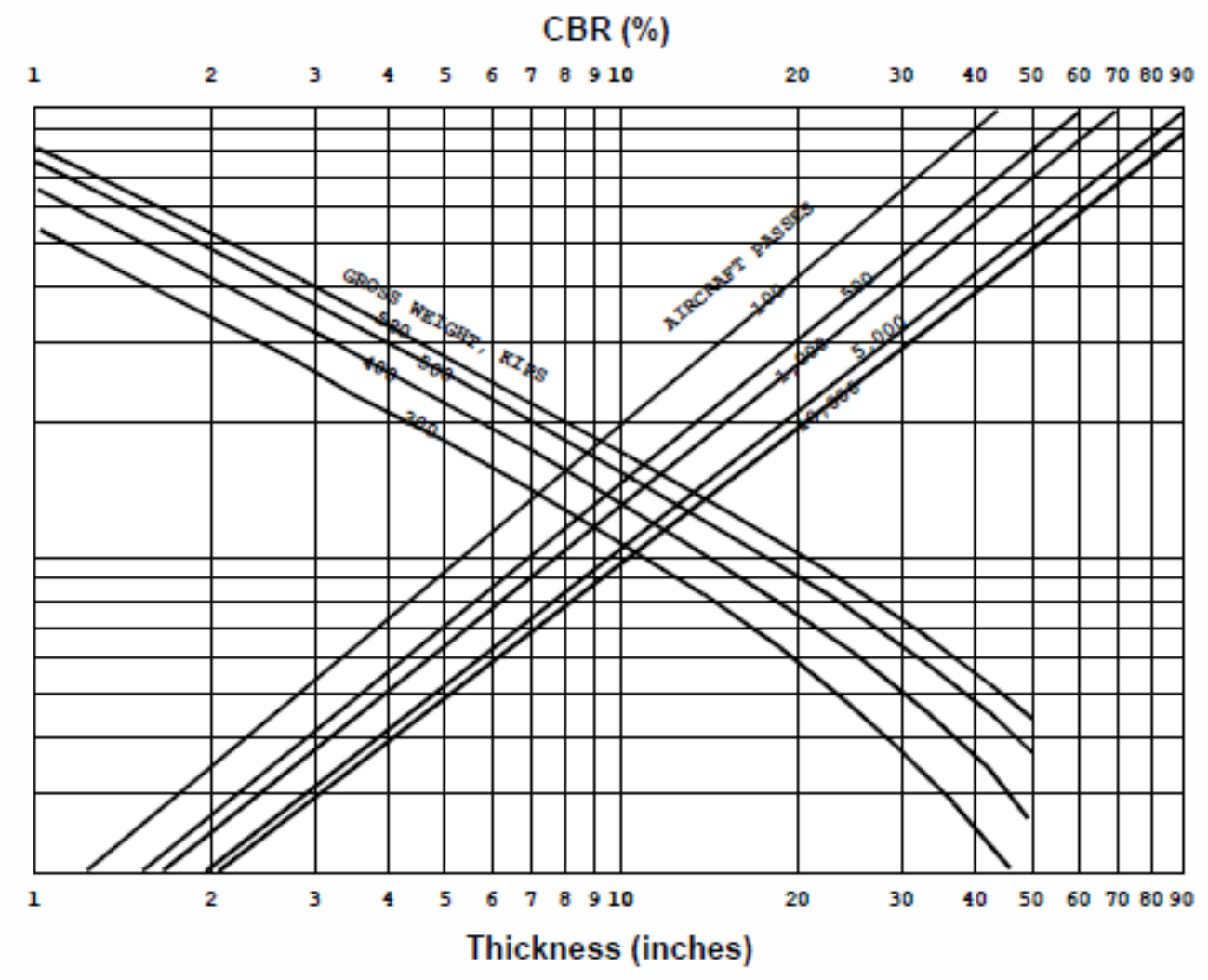

Structural improvements for contingency airfields include the addition of an aggregate or select fill layers, stabilization of the natural subgrade (as discussed previously), or the use of AM-2 aluminum matting.

\subsubsection{Frost conditions}

Frost action can cause subgrade strengths to be reduced significantly during thaw periods. Detrimental frost action will occur if the subgrade contains frost-susceptible materials, the temperature remains below freezing for a considerable amount of time, and an ample supply of ground water exists. If the subgrade is frost susceptible, determine its frost group from Table 10.

Typically, because of their short design life, contingency airfields are not designed for protection against frost action. However, some contingency situations may warrant designing for frost conditions. The design for frost conditions uses the reduced subgrade-strength criterion, which assigns a material to a frost group based upon the material's properties. Table 10 
shows the frost group designations for various material types. Each material is then assigned a Frost Area Soil Support Index (FASSI) number based on its frost group designation. Table 11 illustrates the FASSI numbers for each frost group. The material's FASSI number is then used in lieu of the in-place subgrade CBR to enter the design curves. Therefore, to design for frost conditions, determine the material's FASSI number; and then perform a typical contingency design by using the FASSI number instead of the in-place subgrade CBR. However, if the FASSI designation is greater than the in-place soil's CBR, the final design should use the inplace soil's CBR. For a more detailed frost design, refer to UFC 3-260-02, Chapter 20.

Table 10. Frost group designations based on soil classification for frost design (ETL 97-9, Table 4.5).

\begin{tabular}{|c|c|c|c|}
\hline $\begin{array}{l}\text { Frost } \\
\text { Group }\end{array}$ & Type of Soil & $\begin{array}{c}\text { \% by } \\
\text { Weight } \\
<0.02 \mathrm{~mm}\end{array}$ & $\begin{array}{l}\text { Typical Soil Types } \\
\text { under the USCS }\end{array}$ \\
\hline \multirow[t]{4}{*}{ NFS } & (a.) Gravels (e > 0.25) & $0-3$ & GW, GP \\
\hline & Crushed Stone & $0-3$ & GW, GP \\
\hline & Crushed Rock & $0-3$ & GW, GP \\
\hline & (b.) Sands $(e<0.30)$ & $0-3$ & SW, SP \\
\hline \multirow[t]{3}{*}{ S1 } & (a.) Gravels $(\mathrm{e}<0.25)$ & $0-3$ & \multirow{5}{*}{$\begin{array}{l}\text { GW, GP } \\
\text { GW, GP } \\
\text { GW, GP } \\
\text { GW, GP, GW-GM, GP-GM, } \\
\text { GW-GC, and GP-GC } \\
\text { SW, SP, SW-SM, SP-SM, SW- } \\
\text { SC, and SP-SC } \\
\text { GW-GM, GP-GM, GW-GC, and } \\
\text { GP-GC }\end{array}$} \\
\hline & Crushed Stone & $0-3$ & \\
\hline & (b.) Gravelly soils & $3-6$ & \\
\hline S2 & Sandy soils $(e<0.30)$ & $3-6$ & \\
\hline F1 & Gravelly soils & $6-10$ & \\
\hline $\mathrm{F} 2$ & $\begin{array}{l}\text { (a.) Gravelly soils } \\
\text { (b.) Sands }\end{array}$ & $\begin{array}{c}10-20 \\
6-15\end{array}$ & $\begin{array}{l}\text { GM, GC, GM-GC } \\
\text { SM, SC, SW-SM, SP-SM, SW- } \\
\text { SC SP-SC and SM-SC }\end{array}$ \\
\hline F3 & $\begin{array}{l}\text { (a.) Gravelly soils } \\
\text { (b.) Sands (not very fine silty } \\
\text { sands) }\end{array}$ & $\begin{array}{l}>20 \\
>15\end{array}$ & $\begin{array}{l}\text { GM, GC, GM-GC } \\
\text { SM, SC, SM-SC }\end{array}$ \\
\hline \multirow{4}{*}{$\mathrm{F} 4$} & (c.) Clays (PI > 12) & - & \multirow{4}{*}{$\begin{array}{l}\mathrm{CL}, \mathrm{CH}, \mathrm{ML}-\mathrm{CL} \\
\mathrm{ML}, \mathrm{MH}, \mathrm{ML}-\mathrm{CL} \\
\mathrm{SM}, \mathrm{SC}, \mathrm{SM}-\mathrm{SC} \\
\mathrm{CL}, \mathrm{ML}-\mathrm{CL} \\
\mathrm{CL} \text { or CH layered with ML, } \\
\mathrm{MH}, \mathrm{SM}, \mathrm{SC}, \mathrm{SM}-\mathrm{SC} \text {, or } \\
\text { ML-CL }\end{array}$} \\
\hline & (a.) Silts & 40 & \\
\hline & (b.) Very fine sands & $>15$ & \\
\hline & $\begin{array}{l}\text { (d.) Varved clays or fine- } \\
\text { grained banded } \\
\text { sediments }\end{array}$ & - & \\
\hline TE: & void ratio. NFS indic & & eptible material \\
\hline
\end{tabular}

Table 11. Frost Area Soil Support Indexes (FASSIs) (ETL 97-9, Table 4.6).

\begin{tabular}{||c||c||}
\hline Frost Group of Soils & $\begin{array}{c}\text { Frost Area Soil Support } \\
\text { Index }\end{array}$ \\
\hline \hline NFS & In-place CBR \\
\hline F1 and S1 & 9 \\
\hline F2 and S2 & 6.5 \\
\hline F3 and F4 & 3.5 \\
\hline
\end{tabular}




\subsection{Surface characteristics}

Several documents discuss the required surface conditions for aircraft operations on LZs.

\subsubsection{ETLs 97-9 and 02-19}

The existing rating system for classifying the surface distress level, and therefore operability, on semi-prepared airfields for C-17 Contingency and Training Operations is discussed in Appendix B of ETL 97-9 and in Section 4.2, Semi-Prepared Airfield Condition Index for Unsurfaced or Aggregate Surfaces, of ETL 02-19. It consists of seven distress types that are evaluated on any potential LZs:

- Potholes

- Ruts

- Loose aggregate

- Dust

- Rolling resistant material

- J et blast erosion

- Stabilized layer failure

The ETLs detail dividing the potential LZ into sections and surveying it to determine the extent of each of these distresses. The surface is then assigned an overall distress level. These distress levels are coded as green, amber, and red.

- Green-Operational for low-risk operations

- Amber-Needs monitoring and should be repaired if possible; medium-risk operations

- $\quad$ Red-Dangerous and must be repaired; high-risk operations

When the surface condition is rated as amber, maintenance should be performed as the mission allows. If any single distress is rated as red, the landing-zone safety officer will determine the feasibility of each operation.

This method involves personnel on the ground performing visual surveys of the surface and taking various measurements and is not a remote-sensing procedure. 


\subsubsection{AFI 13-217}

AFI 13-217, Drop and Landing Zone Operations, also offers text on LZ surface tolerances and clearances as follows: Tolerance or roughness will depend on shear strength, hardness, and size of items that cause roughness. Roughness interrupts smooth rotation of aircraft tires and interferes with marginal aerodynamic lift of flight control surfaces at slow speed. Location and frequency of surface crests or wave tops are of paramount importance. The following items may be used as a guide in determining suitability of runway surface, shoulders, and clear areas. Exceeding these limits may result in structural failures of the aircraft. Roughness must be minimized for sustained operations.

The following are issues or features of concerns for the LZ traffic area (runway, overruns, taxiways, and parking apron):

- Rocks. Rocks in traffic areas must be removed, embedded, or interlocked with each other so aircraft tires will traverse the area without causing displacements.

- Soil Balls (dried cohesive dirt clods). Soil balls or dry cohesive dirt clods (clay excluded) up to 6 in. $(15 \mathrm{~cm})$ in diameter that will burst on tire impact are allowed. Hardened clay clods that have similar characteristics as rocks and exceed 4 in. $(10 \mathrm{~cm})$ in diameter must be pulverized or removed from the traffic areas.

- Tree Stumps. Remove all stumps; fill holes, and compact soil to the weight bearing capacity of the surrounding surface.

- Ditches. Eliminate ditches from traffic areas. When filled, the weightbearing capacity must be that of the surrounding area.

- Plowed Fields. Contours of dirt patterns established to reduce erosion, water drain-off, and for planting preparation that have been accomplished by agricultural plowing usually contain a soft core and normally will not require removal. However, such dirt patterns should be examined carefully to determine the need for removal.

- Depressions and Soil Mounds. Depressions and soil mounds do not have sharp corners and are recognized as oval or circular gradual sinks or rises. Level or fill depressions or mounds that exceed $15 \mathrm{in.}$ 
across the top and 6 in. in depth or height until they meet grade tolerance criteria.

- Potholes. Potholes are circular or oval in shape and are distinguished from depressions by their smaller size and sharp corners. Potholes must be filled if they exceed $15 \mathrm{in}$. across their widest point and 6 in. in depth.

\subsubsection{OLS program}

The OLS program generated three new tables that were revised from previous criteria. The first defines the OLS in terms of smoothness, flatness, obstruction, and hydrologic features and is shown as Table 12. The second defines OLS surface-characteristics criteria and was derived from ETL 979 Appendix B (1997), which was discussed in Section4.7.1 (Table 13).

Finally, the overall rating of the entire OLS is determined based on approximation from the total analysis of the surface characteristics from Table 13, the geometry properties (smoothness and flatness) from Table 12, and the soil strength for calculating the loading capacity of the natural soil structure. Table 14 is the culmination of all the ratings for each category, representing the entire LZ from the evaluation information and analysis.

Table 12. OLS geometric evaluation rating used for evaluating OLS (Affleck et al. 2008).

\begin{tabular}{|c|c|c|}
\hline \multirow{2}{*}{$\begin{array}{l}\text { Geometric } \\
\text { criteria }\end{array}$} & \multicolumn{2}{|c|}{ Ratings } \\
\hline & Green & Red \\
\hline Flatness & $\begin{array}{l}\text { Slope: } \\
\quad<3 \% \text { for longitudinal direction } \\
\quad<5 \% \text { for transverse direction }\end{array}$ & $\begin{array}{l}\text { Slope: } \\
\qquad \begin{array}{l}>3 \% \text { for longitudinal direction } \\
>5 \% \text { for transverse direction }\end{array}\end{array}$ \\
\hline Smoothness & $\begin{array}{l}\text { Undulation (grade change, wave- } \\
\text { length): } \\
\qquad<1.5 \% \text { in } \geq \text { less } 61 \text {-m distance }\end{array}$ & $\begin{array}{l}\text { Undulation (grade change, wavelength): } \\
\qquad>1.5 \% \text { in }<\text { less } 61 \text {-m distance }\end{array}$ \\
\hline Obstacles & $\begin{array}{l}\text { No power lines in the vicinity, no trees } \\
\text { or vegetation }<1 \mathrm{~m} \text { ( } 3 \mathrm{ft} \text { ) }\end{array}$ & $\begin{array}{l}\text { Power line } 200 \mathrm{~m} \text { near the OLS, trees or } \\
\text { vegetation }>1 \mathrm{~m}(3 \mathrm{ft})\end{array}$ \\
\hline $\begin{array}{l}\text { Hydrologic } \\
\text { features }\end{array}$ & None & If present \\
\hline
\end{tabular}


Table 13. Surface characteristics used to evaluate OLS (Affleck et al. 2008).

\begin{tabular}{|c|c|c|c|c|}
\hline & Surface categories & Green & Amber & Red \\
\hline & $\begin{array}{l}\text { Potholes } \\
\text { depth } \\
\text { diameter }\end{array}$ & $\begin{array}{l}<100 \mathrm{~mm} \text { (4 in.) and/or } \\
<380 \mathrm{~mm} \text { (15 in.) }\end{array}$ & $\begin{array}{l}100-230 \mathrm{~mm}(4-9 \mathrm{in} .) \text { and } \\
>380 \mathrm{~mm} \text { (15 in.) }\end{array}$ & $\begin{array}{l}>230 \mathrm{~mm}(9 \mathrm{in} .) \text { and } \\
>380 \mathrm{~mm} \text { (15 in.) }\end{array}$ \\
\hline 2 & $\begin{array}{l}\text { Loose aggregate, } \\
\text { coverage }\end{array}$ & $<10 \%$ & 10 to $50 \%$ & $>50 \%$ \\
\hline 3 & Rut depths & $<100 \mathrm{~mm}$ (4 in.) & $100-230 \mathrm{~mm}(4-9$ in.) & $>230 \mathrm{~mm}(9 \mathrm{in})$. \\
\hline 4 & $\begin{array}{l}\text { Rolling resistance material, } \\
\text { depth }\end{array}$ & $<90 \mathrm{~mm}$ (3.5 in.) & $90-195 \mathrm{~mm}(3.5-7.75 \mathrm{in})$. & $>195 \mathrm{~mm}$ (7.75 in.) \\
\hline 5 & Dust & $\begin{array}{l}\text { Does not obstruct } \\
\text { visibility }\end{array}$ & $\begin{array}{l}\text { Partially obstructs visibility, appr. } \\
400 \mathrm{~m} \text { ( } 1 / 4 \text { mile) }\end{array}$ & Thick; obstructs visibility \\
\hline 6 & Jet blast erosion, depth & $<25 \mathrm{~mm}$ (1 in.) & $25-75 \mathrm{~mm}(1-3 \mathrm{in})$. & $>75 \mathrm{~mm}$ ( 3 in.) \\
\hline 7 & Stabilized layer, depth & $<25 \mathrm{~mm}$ (1 in.) & $25-50 \mathrm{~mm}(1-2 \mathrm{in})$. & $>50 \mathrm{~mm}(2 \mathrm{in})$. \\
\hline \multirow{4}{*}{\multicolumn{2}{|c|}{$\begin{array}{l}\text { Animal burrows* } \\
\quad \text { Number of holes } \\
\text { Average holes } \\
\text { Diameter } \\
\text { Area coverage and } \\
\text { spacing }\end{array}$}} & & & \\
\hline & & $<3$ with & 3 to 6 with & $>6$ with \\
\hline & & $<25 \mathrm{~m}$ (1 1 in.) and & $25 \mathrm{~m}$ ( 1 in.) and & $>25 \mathrm{~m}$ ( 1 in.) and \\
\hline & & $\begin{array}{l}10 \text { by } 10 \mathrm{~m} \text { area for every } \\
200 \mathrm{~m}\end{array}$ & 10 by $10 \mathrm{~m}$ area, at every $100 \mathrm{~m}$. & $\begin{array}{l}10 \text { by } 10 \mathrm{~m} \text { area or } \\
\text { bigger, at every } 100 \mathrm{~m} \\
\text { or less. }\end{array}$ \\
\hline \multirow[b]{3}{*}{9} & \multirow{3}{*}{$\begin{array}{l}\text { Mounds* } \\
\text { Height } \\
\text { Base diameter }\end{array}$} & & & \\
\hline & & $<100 \mathrm{~mm}$ (4 in.) and/or & $100-230 \mathrm{~mm}(4-9 \mathrm{in}$.$) and$ & $>230 \mathrm{~mm}(9 \mathrm{in})$. \\
\hline & & $<380 \mathrm{~mm}$ (15 in.) & $>380 \mathrm{~mm}$ (15 in.) & $>380 \mathrm{~mm}$ (15 in.) \\
\hline & \multirow{3}{*}{$\begin{array}{l}\text { Vegetation* } \\
\text { Height } \\
\text { Stem or branch } \\
\text { diameter }\end{array}$} & & & \\
\hline & & $<0.5 \mathrm{~m}(1.5 \mathrm{ft})$ & $<0.5 \mathrm{~m}(1.5 \mathrm{ft})$ & $>0.5 \mathrm{~m}(1.5 \mathrm{ft})$ \\
\hline 10 & & $\begin{array}{l}\text { no branches or bushes and } \\
\text { tall grass }\end{array}$ & $<1$-in. diameter & $>1$ in. \\
\hline & \multirow{3}{*}{\begin{tabular}{|l} 
Standing water* \\
Depth \\
Diameter
\end{tabular}} & & & \\
\hline & & zero & $0.25 \mathrm{~mm}$ (1 in.) and & $>50 \mathrm{~mm}(2 \mathrm{in}$.) and \\
\hline 11 & & & $>380 \mathrm{~mm}$ (15 in.) & $>380 \mathrm{~mm}$ (15 in.) \\
\hline 12 & $\begin{array}{l}\text { Surface drainage paths,* } \\
\text { depth }\end{array}$ & $<100 \mathrm{~mm}$ (4 in.) & 100 to $230 \mathrm{~mm}$ ( 4 to 9 in.) & $>230 \mathrm{~mm}(9 \mathrm{in})$. \\
\hline \multirow[b]{3}{*}{13} & \multirow{3}{*}{$\begin{array}{l}\text { Surface debris and organ- } \\
\text { ics materials* } \\
\text { Amount of organics } \\
\text { Diameter of logs or } \\
\text { debris }\end{array}$} & & & \\
\hline & & $<5 \%$ and & 5 to $20 \%$ and & $>20 \%$ and \\
\hline & & $<50 \mathrm{~mm}(2 \mathrm{in})$. & $>50-100 \mathrm{~mm}$ ( 2 to $4 \mathrm{in}$.) & $>100 \mathrm{~mm}$ \\
\hline 14 & Snow depthis* & zero & 25 to $50 \mathrm{~mm}$ ( 1 to 2 in.) & $>50 \mathrm{~mm}(2 \mathrm{in})$. \\
\hline
\end{tabular}


Table 14. The overall rating of the entire OLS for the C-17 and C-130 (Affleck et al. 2008).

\begin{tabular}{|c|c|c|c|}
\hline Categories & Excellent or Pass & Marginal or Caution & $\begin{array}{l}\text { Unacceptable or } \\
\text { Fail }\end{array}$ \\
\hline Surface characteristics & $\begin{array}{c}\text { Green: } \geq 80 \% \text { ( } 11 \text { out of } 14), \\
\text { Amber: } \leq 20 \% \text { ( } 3 \text { out of } 14), \\
\text { Red: zero }\end{array}$ & $\begin{array}{l}\text { Green: } 50 \% \text {, } \\
\text { Amber: } \geq 50 \% \text {, } \\
\text { Red: zero }\end{array}$ & $\begin{array}{c}\text { Green: zero, } \\
\text { Amber: } \leq 50 \% \text {, } \\
\text { Red: } \geq 50 \%\end{array}$ \\
\hline Geometric properties & Green: $100 \%$ & Green: $100 \%$ & Green: $<100 \%$ \\
\hline $\begin{array}{l}\text { Aircrafts loading capacity using } \\
\text { charts or PCASE: } \\
\text { Allow. gross load } \\
\text { Number of passes }\end{array}$ & $\begin{array}{l}\text { Between } \min . \& \text { max. weight } \\
\qquad \geq 5 \text { and } \leq 10\end{array}$ & $\begin{array}{c}\text { Between } \min . \& \text { max. } \\
\text { weight } \\
\geq 3 \text { and }<5\end{array}$ & $\begin{array}{c}\text { Minimum weight or } \\
\text { less } \\
<2\end{array}$ \\
\hline \multicolumn{4}{|l|}{$\begin{array}{l}\text { Or using average CBR catego- } \\
\text { ries: } \\
\text { C-17 } \\
\text { CBR }\end{array}$} \\
\hline $\begin{array}{l}\text { C-130 } \\
\text { CBR } \\
@ \text { min. weight } \\
@ \text { max. weight }\end{array}$ & $\begin{array}{l}>4 \\
<12\end{array}$ & $\begin{array}{l}>2 \& \leq 4 \\
>6 \& \leq 12\end{array}$ & $\begin{array}{l}\leq 2 \\
\leq 6\end{array}$ \\
\hline $\begin{array}{l}\text { C17: } \text { minimum weight }=126.6 \\
C 130: \text { minimum weight }=31 \mathrm{n}\end{array}$ & ton $(279,000 \mathrm{lb})$, maxim & 265 metric ton & (b) \\
\hline
\end{tabular}

\subsection{Surface friction for C-17 contingency operations}

The criteria and procedures required to determine the surface friction of a potential LZ provided to date are brief and pertain to semi-prepared airfield surfaces, with the exception of some predictions of landing friction requirements by soil type. However, they are presented here because surface friction consideration is required when siting unimproved contingency LZs.

\subsubsection{Landing}

Appendix D of ETL 97-9 presents the basic criteria and procedures used to determine whether a semi-prepared contingency airfield is suitable for C17 operations in terms of surface-friction characteristics and usable runway length. It includes appropriate data, figures, and evaluation charts.

The stopping-friction guidance is based on the Runway Condition Rating (RCR). There are three ways to calculate the $\mathrm{RCR}$ value required for $\mathrm{C}-17$ contingency operations:

- Convert Bowmonk “Mean Deceleration” readings into RCR.

- Convert soil type to RCR.

- Convert ground-vehicle skid distance measurements to RCR. 
Converting Bowmonk "Mean Deceleration" readings into aircraft RCR values is by far the most accurate method of obtaining an RCR value. Data collected with the Bowmonk can be used in Table 15 to convert the friction measurements into an equivalent C-17 RCR. The mean deceleration measurements are used to calculate an overall average mean value. This average value is compared to the values in column two (mean) to determine the appropriate C-17 RCR value.

There are two alternate friction prediction procedures: correlating the soil type to RCR (Table 16) and directly measuring the skid distance with a ground vehicle and correlating to RCR. Of the two alternate procedures, measuring the skid distance is more accurate and preferable over correlating RCR to soil type only.

Table 15. Stopping friction guidance (preliminary) (ETL 97-9, Table D.7).

\begin{tabular}{|c|c|c|c|}
\hline $\begin{array}{c}\text { Semi-Prepared } \\
\text { Runway }\end{array}$ & Surface Condition & 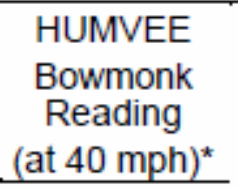 & RCR \\
\hline Unstabilized & Visibly dry, dry depth $2^{\prime \prime}$ & $>61$ & 20 \\
\hline Cement Stabilized & Visibly dry, no puddles & $>61$ & 20 \\
\hline Either & Damp to wet & N/A & 4 \\
\hline
\end{tabular}

Note: Average of all eight "mean decel (in $\% \mathrm{~g}$ ) readings.

Table 16. Correlation between soil type and RCR (ETL 97-9, Table D.8).

\begin{tabular}{|c|c|c|c|}
\hline Soil Type & $\begin{array}{c}\text { USCS } \\
\text { Classification }\end{array}$ & $\begin{array}{c}\text { Water } \\
\text { Content }\end{array}$ & C-17 RCR \\
\hline Well Graded Gravels & GW & Dry & 20 \\
\hline Clean Sands (< $5 \%$ fines) & SW, SP & Dry & 22 \\
\hline Clayey Sands, Silty Sands ( $>12 \%$ fines) & $\mathrm{SC}, \mathrm{SM}$ & Dry & 22 \\
\hline Low Plaskicity Clays \& Silts & $\mathrm{CL}, \mathrm{ML}$ & Dry & 23 \\
\hline
\end{tabular}

\subsubsection{Takeoff}

The rolling-friction factor is important when the unsurfaced airfield is soft enough to produce appreciable loose till. The aircraft must "plow" through this loose till, and this produces a requirement for slightly longer takeoff distances. This loose-till depth should be measured at five locations on the runway in accordance with the measuring procedures described in Appendix B of ETL 97-9. Suggested measurement locations include touchdown area; initial braking zone; point of rotation; departure end of runway; and 
other areas where the surface may be softened due to poor drainage, improper construction, aircraft turning, etc. Calculate the average of these five till-depth measurements to establish the overall runway till depth, then refer to Table 17 to determine the approximate rolling-friction factor for the runway surface measured.

Table 17. Rolling-friction guidance (ETL 97-9, Table D.9).

\begin{tabular}{ccc}
\hline $\begin{array}{c}\text { Semi-prepared } \\
\text { Runway }\end{array}$ & Dry Till Depth & Rolling Friction Factor \\
\hline Unstabilized (dry) & 0 to 1.5 inches & 5 \\
& 1.51 to 3.5 inches & 10 \\
& 3.51 to 5.75 inches & 15 \\
& 5.76 to 7.75 inches & 20 \\
& $>7.75$ inches & Maintenance Required \\
Unstabilized (damp to wet) & 0 to 1.0 inches & 5 \\
Cement stabilized & 0 to 0.5 inches & 2 \\
\hline
\end{tabular}




\section{$5 \quad$ Landing Zones-Rotary Wing}

Helicopter LZs consist of the runway and helipad surface, shoulders, overruns, approach slope surfaces, safety clearances, and other imaginary airspace surfaces. Again, the majority of these criteria come from UFC 3-26001 (2008). Landing lanes and hoverpoints, which are included in the UFC, are not discussed in this review; however, text referring to them may remain in the reproduced tables. AFI 13-217 also offers rotary-wing LZ criteria, though it does not seem to add much content to that already covered by UFC 3-260-01.

\subsection{Rotary-wing runway}

A (rotary-wing) helicopter runway allows for a helicopter to quickly land and roll to stop, compared to the hovering stop used for a vertical helipad approach.

Consider the strength, direction, and frequency of the local winds when orienting a runway to minimize crosswinds. Follow the methods in Chapter 3 of UFC 3-260-01 for fixed-wing runways.

Table 18 presents the dimensional criteria for (rotary-wings) helicopter runways. Figure 9 illustrates the layout for rotary-wing runways, including clear zones, for visual flight rules (VFR) runways, and Figure 10 and Figure 11 illustrates for instrument flight rules (IFR) runways.

Table 18. Rotary-wing runways (UFC 3-260-01, Table 4-1).

\begin{tabular}{|c|c|c|c|}
\hline \multicolumn{4}{|r|}{ Rotary-Wing Runways } \\
\hline \multicolumn{2}{|r|}{ Item } & \multirow[b]{2}{*}{ Requirement } & \multirow[b]{2}{*}{ Remarks } \\
\hline No. & Description & & \\
\hline 1 & Basic length & $490 \mathrm{~m}(1,600 \mathrm{ft})$ & 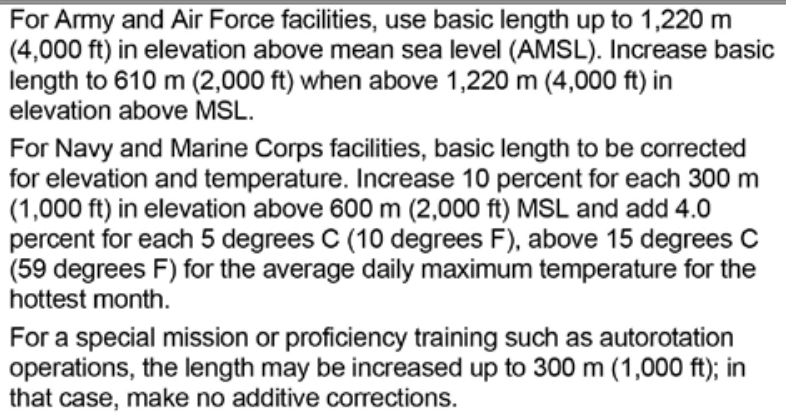 \\
\hline & & $137.2 \mathrm{~m} \mathrm{(450 \textrm {ft } )}$ & For facilities constructed prior to publication of this manual. \\
\hline
\end{tabular}


Table 18 (cont.). Rotary-wing runways (UFC 3-260-01, Table 4-1).

\begin{tabular}{|c|c|c|c|}
\hline \multicolumn{4}{|r|}{ Rotary-Wing Runways } \\
\hline \multicolumn{2}{|r|}{ Item } & \multirow[b]{2}{*}{ Requirement } & \multirow[b]{2}{*}{ Remarks } \\
\hline No. & Description & & \\
\hline 2 & Width & $23 \mathrm{~m}(75 \mathrm{ft})$ & $\begin{array}{l}\text { For Navy and Marine Corps facilities, increase width to } 30 \mathrm{~m} \\
\text { (100 ft) on runways which regularly accommodate } \mathrm{H}-53 \text {. }\end{array}$ \\
\hline 3 & $\begin{array}{l}\text { Longitudinal } \\
\text { grade }\end{array}$ & Max. 1.0 percent & $\begin{array}{l}\text { Maximum longitudinal grade change is } 0.167 \text { percent per } 30 \text { linear } \\
\text { meters ( } 100 \text { linear feet) of runway. Exceptions: } 0.4 \text { percent per } \\
30 \text { linear meters ( } 100 \text { linear feet) for edge of runways at runway } \\
\text { intersections. }\end{array}$ \\
\hline 4 & $\begin{array}{l}\text { Transverse } \\
\text { grade }\end{array}$ & $\begin{array}{l}\text { Min. } 1.0 \text { percent } \\
\text { Max. } 1.5 \text { percent }\end{array}$ & $\begin{array}{l}\text { From centerline of runway. } \\
\text { Runway may be crowned or uncrowned. }\end{array}$ \\
\hline 5 & $\begin{array}{l}\text { Paved } \\
\text { shoulders }\end{array}$ & & See Table 4-4. \\
\hline \multirow[t]{6}{*}{6} & $\begin{array}{l}\text { Runway lateral } \\
\text { clearance zone } \\
\text { (corresponds to } \\
\text { half the width of } \\
\text { primary surface } \\
\text { area) }\end{array}$ & $45.72 \mathrm{~m} \mathrm{(150 \textrm {ft } )}$ & VFR operations \\
\hline & & $114.30 \mathrm{~m} \mathrm{(375 \textrm {ft } )}$ & IFR operations \\
\hline & & See Remarks & $\begin{array}{l}\text { Measured perpendicularly from centerline of runway. This area is to } \\
\text { be clear of fixed and mobile obstacles. In addition to the lateral } \\
\text { clearance criterion, the vertical height restriction on structures and } \\
\text { parked aircraft as a result of the transitional slope must be taken } \\
\text { into account. }\end{array}$ \\
\hline & & & $\begin{array}{l}\text { (1) Fixed obstacles include man-made or natural features } \\
\text { constituting possible hazards to moving aircraft. Navigational } \\
\text { aids and meteorological equipment are possible exceptions. For } \\
\text { Army and Air Force, siting exceptions for navigational aids and } \\
\text { meteorological facilities are provided in Appendix B, Section 13, } \\
\text { of this manual. For Navy and Marine Corps, siting exceptions for } \\
\text { navigational aids and meteorological facilities are found in } \\
\text { paragraph 2-10.9. }\end{array}$ \\
\hline & & & $\begin{array}{l}\text { (2) Mobile obstacles include parked aircraft, parked and moving } \\
\text { vehicles, railroad cars and similar equipment. }\end{array}$ \\
\hline & & & $\begin{array}{l}\text { (3) Taxiing aircraft are exempt from this restriction. However, } \\
\text { parallel taxiways (exclusive of shoulder width) must be located in } \\
\text { excess of the lateral clearance distance. }\end{array}$ \\
\hline 7 & $\begin{array}{l}\text { Grades within } \\
\text { the primary } \\
\text { surface area in } \\
\text { any direction }\end{array}$ & $\begin{array}{l}\text { Min. } 2.0 \text { percent } \\
\text { Max. } 5.0 \text { percent }\end{array}$ & Exclusive of pavement and shoulders. \\
\hline 8 & Overrun & & See Table 4-5. \\
\hline
\end{tabular}


Table 18 (cont.). Rotary-wing runways (UFC 3-260-01, Table 4-1).

\begin{tabular}{|c|c|c|c|}
\hline \multicolumn{4}{|r|}{ Rotary-Wing Runways } \\
\hline \multicolumn{2}{|r|}{ Item } & \multirow[b]{2}{*}{ Requirement } & \multirow[b]{2}{*}{ Remarks } \\
\hline No. & Description & & \\
\hline \multirow[t]{5}{*}{9} & $\begin{array}{l}\text { Distance from } \\
\text { the centerline of } \\
\text { a fixed-wing } \\
\text { runway to the } \\
\text { centerline of a } \\
\text { parallel rotary- } \\
\text { wing runway, } \\
\text { helipad, or } \\
\text { landing lane } \\
\end{array}$ & $\begin{array}{l}\text { Min. } 213.36 \mathrm{~m} \\
\quad(700 \mathrm{ft})\end{array}$ & $\begin{array}{l}\text { Simultaneous VFR operations for Class A runway and Army Class } \\
\text { B runway }\end{array}$ \\
\hline & & $\begin{array}{l}\text { Min. } 304.80 \mathrm{~m} \\
(1,000 \mathrm{ft})\end{array}$ & $\begin{array}{l}\text { Simultaneous VFR operations for Class B Runway for Air Force, } \\
\text { Navy and Marine Corps. }\end{array}$ \\
\hline & & $\begin{array}{l}\text { Min. } 213.36 \mathrm{~m} \\
\quad(700 \mathrm{ft})\end{array}$ & $\begin{array}{l}\text { Non-simultaneous VFR and IFR operations. } \\
\text { Distance may be reduced to } 60.96 \mathrm{~m} \text { ( } 200 \mathrm{ft} \text { ); however, waiver must } \\
\text { be based on wake-turbulence and jet blast. } \\
\text { In locating the helipad, consideration must be given to hold position } \\
\text { marking. } \\
\text { Rotary-wing aircraft must be located on the apron side of the hold } \\
\text { position markings (away from the runway) during runway } \\
\text { operations. }\end{array}$ \\
\hline & & $\begin{array}{l}\text { Min. } 762.00 \mathrm{~m} \\
(2,500 \mathrm{ft})\end{array}$ & $\begin{array}{l}\text { IFR using simultaneous operations (depart-depart) (depart- } \\
\text { approach). }\end{array}$ \\
\hline & & $\begin{array}{l}\text { Min. } 1,310.64 \mathrm{~m} \\
\quad(4,300 \mathrm{ft})\end{array}$ & IFR using simultaneous approaches. \\
\hline \multirow[t]{3}{*}{10} & $\begin{array}{l}\text { Distance } \\
\text { between } \\
\text { centerlines of: } \\
\text { (a) parallel } \\
\text { rotary-wing } \\
\text { runways, } \\
\text { helipads, or any } \\
\text { combination } \\
\text { thereof; } \\
\text { (b) landing lane } \\
\text { and parallel } \\
\text { rotary-wing } \\
\text { runway or } \\
\text { helipad }\end{array}$ & $\begin{array}{l}\text { Min. } 213.36 \mathrm{~m} \\
\quad(700 \mathrm{ft})\end{array}$ & $\begin{array}{l}\text { VFR without intervening parallel taxiway between centerlines. For } \\
\text { US Army, distance may be reduced to } 60.96 \mathrm{~m} \text { ( } 200 \mathrm{ft} \text { ) between } \\
\text { parallel helipads for non-simultaneous operations. } \\
\text { In locating the helipad, consideration must be given to hold position } \\
\text { marking. } \\
\text { Rotary-wing aircraft must be located on the apron side of the hold } \\
\text { position markings (away from the runway) during runway } \\
\text { operations. }\end{array}$ \\
\hline & & $\begin{array}{l}\text { Min. } 762.00 \mathrm{~m} \\
(2,500 \mathrm{ft})\end{array}$ & $\begin{array}{l}\text { IFR using simultaneous operations (depart-depart) (depart- } \\
\text { approach). }\end{array}$ \\
\hline & & $\begin{array}{l}\text { Min. } 1,310.64 \mathrm{~m} \\
\quad(4,300 \mathrm{ft})\end{array}$ & IFR using simultaneous approaches. \\
\hline
\end{tabular}

\section{NOTES:}

1. Metric units apply to new airfield construction and, where practical, modification to existing airfields and heliports, as discussed in paragraph 1-4.4.

2. The criteria in this manual are based on aircraft specific requirements and are not direct conversions from inch-pound (English) dimensions. Inch-pound units are included only as a reference to the previous standard.

3. Airfield and heliport imaginary surfaces and safe wingtip clearance dimensions are shown as a direct conversion from inch-pound to SI units. 
Figure 9. Helicopter VFR runway (UFC 3-260-01, Fig. 4-1).

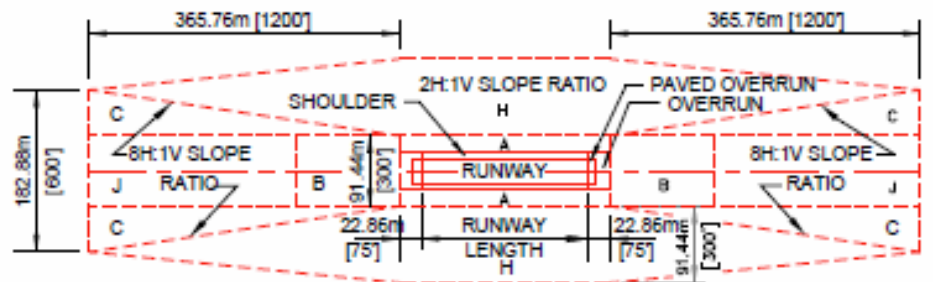

$\frac{\text { PLAN }}{\text { NTES }}$

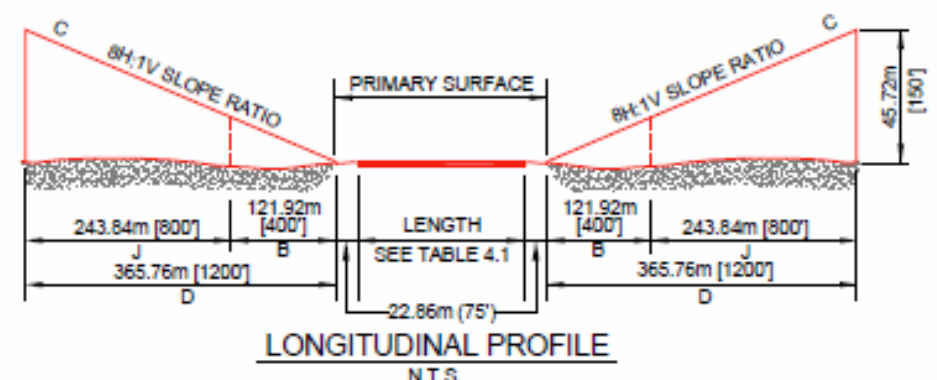

N.T.S.

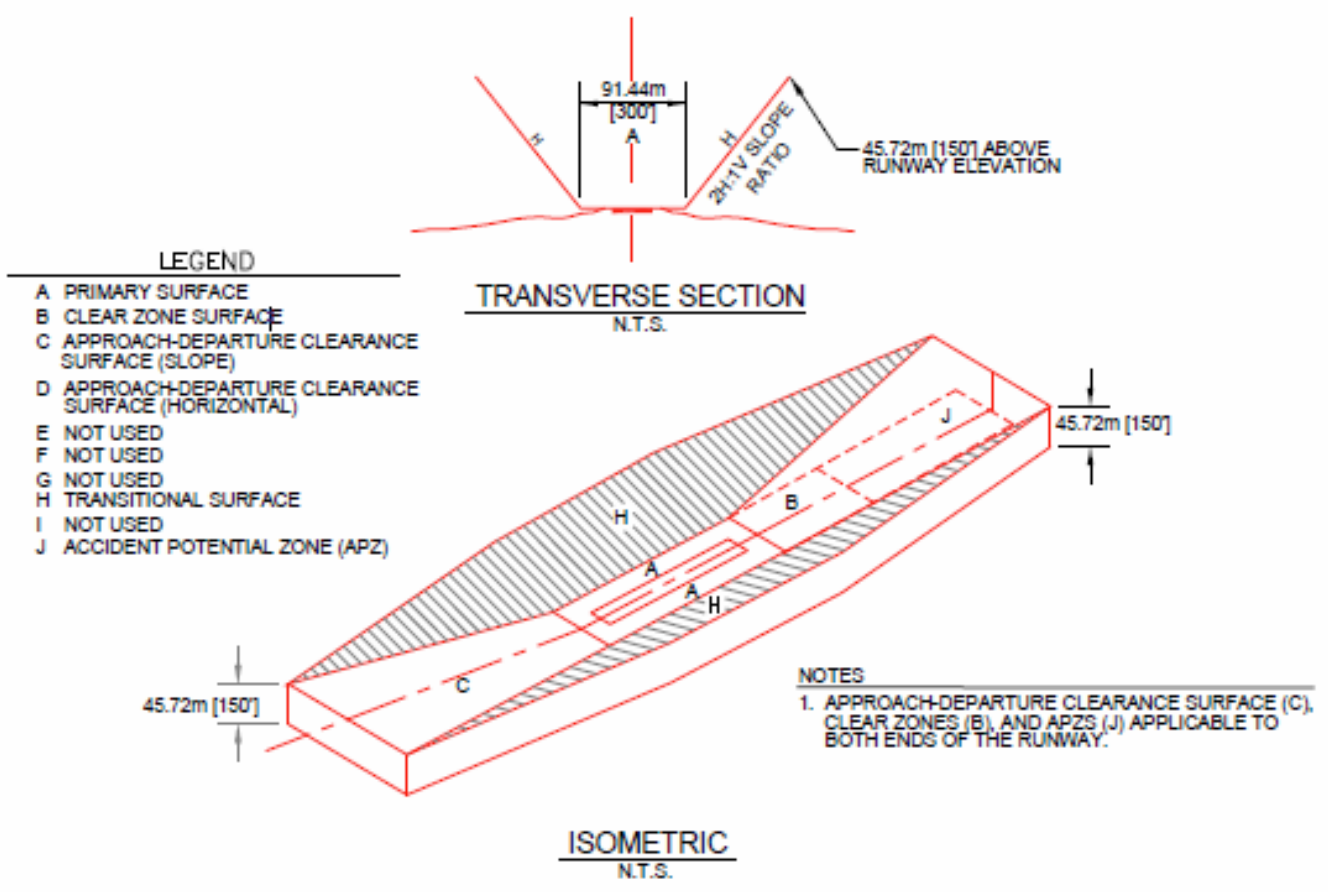


Figure 10. Helicopter IFR runway (UFC 3-260-01, Fig. 4-2).

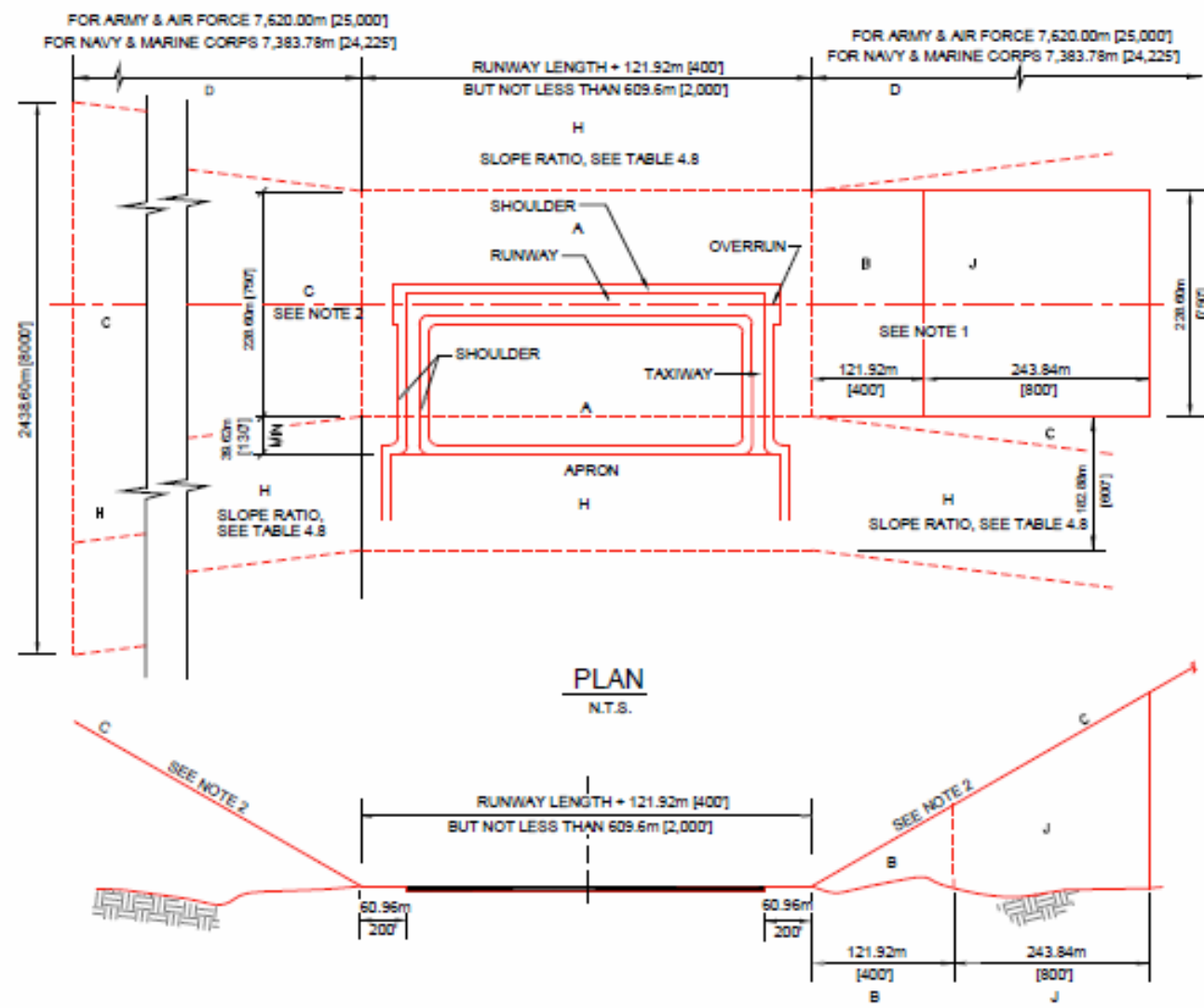

LONGITUDINAL PROFILE

K.T.S.

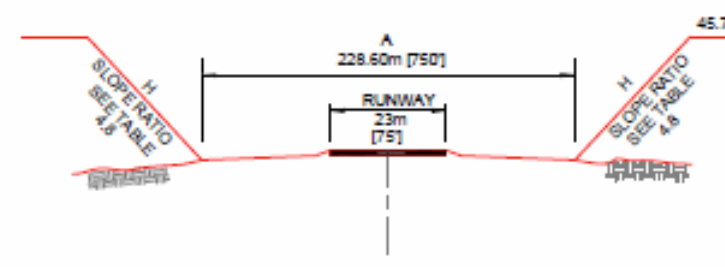

$45.72 \mathrm{~m}$ [150] ELEV.

TRANSVERSE SECTION

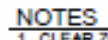

1. CLEARZ

2. APPROACHOEPARTURE CLEARNNE SUREACE SLOPE 
Figure 11. IFR airspace imaginary surfaces: IFR Helicopter runways and helipad (UFC 3-26001, Fig. 4-3).

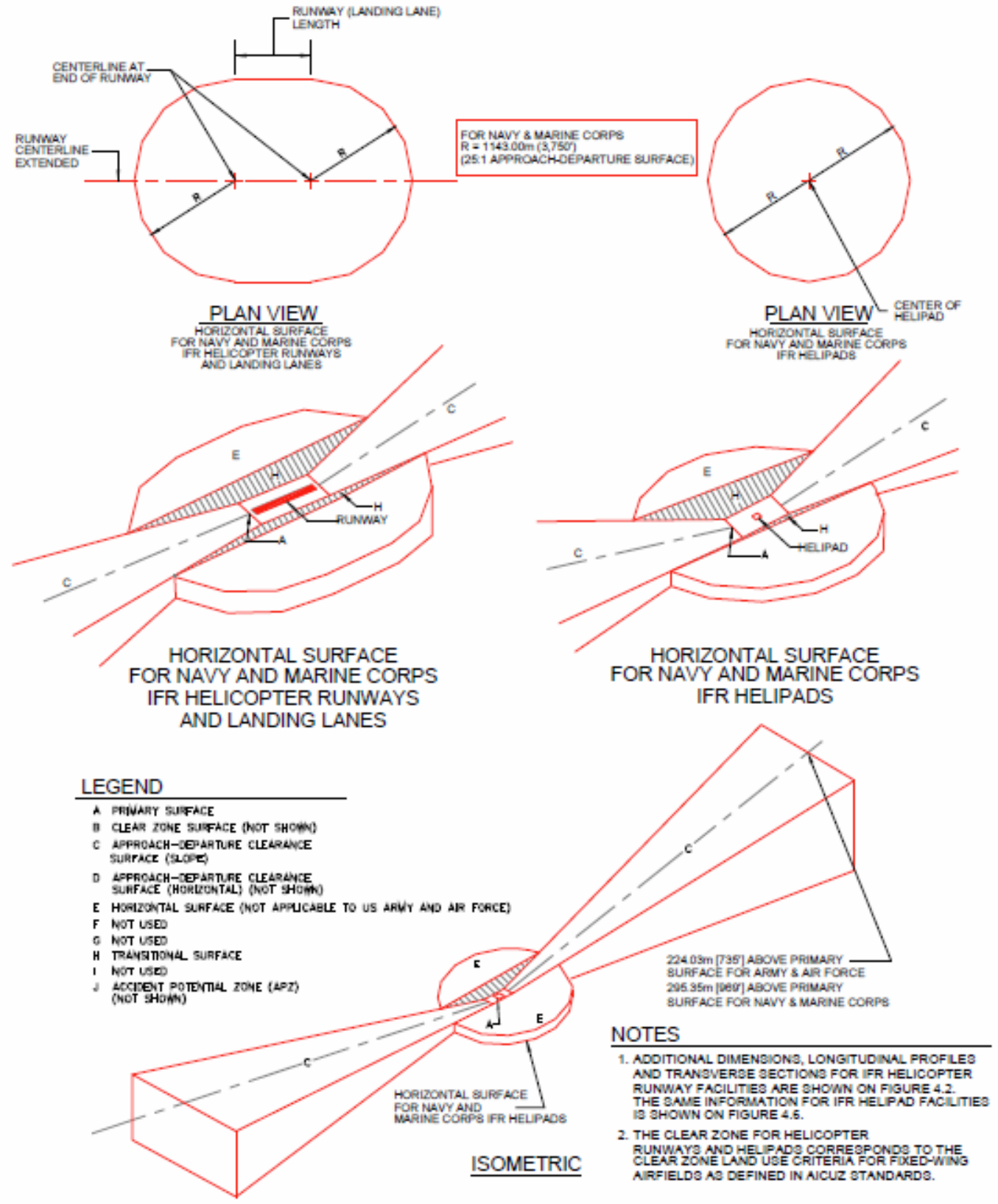

\subsection{Helipads}

Helipads allow for helicopter hovering, landing, and takeoff. When facilities do not provide helicopter runways, helipads are the landing and takeoff locations for helicopters. The Army and Air Force provide for three types of helipads: standard VFR helipad, limited-use helipad, and IFR hel- 
ipad. The Navy and Marine Corps provide only one type of helipad: standard-size helipad. The type of helipad depends on these operational requirements:

- Standard VFR Helipad. VFR design standards are used when no requirement exists or will exist in the future for an IFR helipad. Criteria for this type of helipad accommodate most helipad lighting systems.

- Limited Use Helipad. This is a VFR rotary-wing facility for use only by observation, attack, and utility helicopters. This type of helipad supports only occasional operations at special locations such as hospitals, headquarters facilities, missile sites, and other similar locations. Limited-use helipads may be located on airfields where one or more helipads are required to separate observation, attack, and utility helicopter traffic from heavy and cargo helicopter traffic or fixed-wing traffic.

- IFR Helipad. IFR design standards are used when an instrument approach capability is essential to the mission and no other instrument landing facilities, either fixed wing or rotary wing, are located within an acceptable commuting distance to the site.

A helipad location should be selected with regard to mission requirements, overall facility development, approach-departure surfaces, and local wind conditions. When a helipad is to be located near fixed- and rotary-wing runways, its location should be based on the type of operations in accordance with the criteria in Table 18.

At individual helipad sites where it is necessary to have one or more helicopters on standby, an area adjacent to the helipad but clear of the landing approach and transitional surfaces should be designated for standby parking.

Table 19 presents dimensional criteria for the layout and design of helipads. Figure 12 through Figure 14 illustrates layouts for standard, limited use, and IFR helipads, including clear zones. 
Table 19. Rotary-Wing helipads (UFC 3-260-01, Table 4-2).

\begin{tabular}{|c|c|c|c|}
\hline \multicolumn{4}{|c|}{ Rotary-Wing Helipads and Hoverpoints } \\
\hline \multicolumn{2}{|r|}{ Item } & \multirow[b]{2}{*}{ Requirement } & \multirow[b]{2}{*}{ Remarks } \\
\hline No. & Description & & \\
\hline \multirow[t]{3}{*}{1} & Size & $\begin{array}{l}15 \mathrm{~m} \times 15 \mathrm{~m} \\
(50 \mathrm{ft} \times 50 \mathrm{ft}) \\
\text { min. }\end{array}$ & Air Force and Army VFR limited use helipads \\
\hline & & $\begin{array}{l}30 \mathrm{~m} \times 30 \mathrm{~m} \\
(100 \mathrm{ft} \times 100 \mathrm{ft}) \\
\mathrm{min} .\end{array}$ & Standard VFR and IFR helipad \\
\hline & & $9 \mathrm{~m}(30 \mathrm{ft})$ diameter & Hoverpoints \\
\hline 2 & Grade & $\begin{array}{l}\text { Min. } 1.0 \text { percent } \\
\text { Max. } 1.5 \text { percent }\end{array}$ & $\begin{array}{l}\text { Grade helipad in one direction. Hoverpoints should be } \\
\text { domed to a } 150-\mathrm{mm} \text { (6-in) height at the center. }\end{array}$ \\
\hline 3 & Paved shoulders & & See Table 4-4. \\
\hline \multirow[t]{5}{*}{4} & $\begin{array}{l}\text { Size of primary surface } \\
\text { (center primary surface } \\
\text { on helipad) }\end{array}$ & $\begin{array}{l}45.72 \mathrm{~m} \times 45.72 \\
(150 \mathrm{ft} \times 150 \mathrm{ft}) \\
\mathrm{min} .\end{array}$ & $\begin{array}{l}\text { Hoverpoints } \\
\text { Air Force and Army limited use VFR helipad }\end{array}$ \\
\hline & & & Navy and Marine Corps Standard VFR helipad \\
\hline & & $\begin{array}{l}91.44 \mathrm{~m} \times 91.44 \mathrm{~m} \\
(300 \mathrm{ft} \times 300 \mathrm{ft})\end{array}$ & Air Force and Army standard VFR helipad \\
\hline & & $\begin{array}{l}472.44 \mathrm{~m} \times 228.60 \mathrm{~m} \\
(1,550 \mathrm{ft} \times 750 \mathrm{ft})\end{array}$ & $\begin{array}{l}\text { Standard IFR. } \\
\text { Long dimension in direction of helicopter approach. }\end{array}$ \\
\hline & & $\begin{array}{c}228.60 \mathrm{~m} \times 228.60 \mathrm{~m} \\
(750 \mathrm{ft} \times 750 \mathrm{ft})\end{array}$ & Army and Air Force IFR same direction ingress/egress. \\
\hline 5 & $\begin{array}{l}\text { Grades within the } \\
\text { primary surface area in } \\
\text { any direction }\end{array}$ & $\begin{array}{l}\text { Min. of } 2.0 \text { percent prior } \\
\text { to channelization. }{ }^{*} \\
\text { Max. } 5.0 \text { percent }\end{array}$ & $\begin{array}{l}\text { Exclusive of pavement and shoulders. } \\
\text { For IFR helipads, the grading requirements apply to a } \\
91.44 \mathrm{~m} \times 91.44 \mathrm{~m}(300 \mathrm{ft} \times 300 \mathrm{ft} \text { ) area centered on the } \\
\text { helipad. } \\
\text { The balance of the area is to be clear of obstructions and } \\
\text { rough graded to the extent necessary to reduce damage } \\
\text { to aircraft in event of an emergency landing. For VFR } \\
\text { helipads, the grade requirements apply to the entire } \\
\text { primary surface. }\end{array}$ \\
\hline \multirow[t]{2}{*}{6} & Length of clear zone ${ }^{\star *}$ & $\begin{array}{c}121.92 \mathrm{~m} \\
(400 \mathrm{ft})\end{array}$ & $\begin{array}{l}\text { Hoverpoints, VFR, and standard IFR helipads. Begins } \\
\text { at the end of the primary surface. }\end{array}$ \\
\hline & & $\begin{array}{c}251.46 \mathrm{~m} \\
(825 \mathrm{ft})\end{array}$ & Army and Air Force IFR same direction ingress/egress. \\
\hline \multirow[t]{4}{*}{7} & Width of clear zone $e^{\star *}$ & & $\begin{array}{l}\text { Corresponds to the width of the primary surface. Center } \\
\text { clear zone width on extended center of the pad. }\end{array}$ \\
\hline & & $\begin{array}{l}45.72 \mathrm{~m} \\
(150 \mathrm{ft})\end{array}$ & $\begin{array}{l}\text { Air Force and Army VFR limited use helipads and } \\
\text { hoverpoints. } \\
\text { Navy and Marine Corps Standard VFR. }\end{array}$ \\
\hline & & $\begin{array}{l}91.44 \mathrm{~m} \\
(300 \mathrm{ft})\end{array}$ & $\begin{array}{l}\text { Air Force and Army standard VFR helipad and VFR } \\
\text { helipad same direction ingress/egress. }\end{array}$ \\
\hline & & $\begin{array}{c}228.60 \mathrm{~m} \\
(750 \mathrm{ft})\end{array}$ & Standard IFR helipad \\
\hline 8 & $\begin{array}{l}\text { Grades of clear zone } \\
\text { any direction }\end{array}$ & 5.0 percent max & $\begin{array}{l}\text { Area to be free of obstructions. Rough grade and turf } \\
\text { when required. }\end{array}$ \\
\hline \multirow[t]{2}{*}{9} & APZI length*** & $\begin{array}{c}243.84 \mathrm{~m} \\
(800 \mathrm{ft})\end{array}$ & Hoverpoints, VFR, and standard IFR \\
\hline & & $\begin{array}{c}121.92 \mathrm{~m} \\
(400 \mathrm{ft})\end{array}$ & Army and Air Force IFR same direction ingress/egress \\
\hline \multirow[t]{3}{*}{10} & APZ I width & $\begin{array}{l}45.72 \mathrm{~m} \\
(150 \mathrm{ft})\end{array}$ & $\begin{array}{l}\text { Army and Air Force VFR limited use and hoverpoints; } \\
\text { Navy and Marine Corps standard VFR }\end{array}$ \\
\hline & & $\begin{array}{l}91.44 \mathrm{~m} \\
(300 \mathrm{ft})\end{array}$ & Army and Air Force standard VFR \\
\hline & & $\begin{array}{c}228.60 \mathrm{~m} \\
(750 \mathrm{ft})\end{array}$ & Standard IFR \\
\hline 11 & $\begin{array}{l}\text { Distance between } \\
\text { centerline of helipad } \\
\text { and fixed- or } \\
\text { rotary-wing runways }\end{array}$ & & See Table 4-1. \\
\hline \multicolumn{4}{|c|}{$\begin{array}{l}\text { * Bed of channel may be flat. } \\
\text { ** The clear zone area for helipads corresponds to the clear zone land use criteria for fixed-wing airfields as } \\
\text { defined in DOD AICUZ standards. The remainder of the approach-departure zone corresponds to APZ } \\
\text { I land use criteria similarly defined. APZ II criteria is not applicable for rotary-wing aircraft. } \\
\text { *** There are no grading requirements for APZ I. }\end{array}$} \\
\hline \multicolumn{4}{|c|}{$\begin{array}{l}\text { 1. Metric units apply to new airfield construction and, where practical, modification to existing airfields and } \\
\text { heliports, as discussed in paragraph } 1-4.4 \text {. } \\
\text { 2. The criteria in this manual are based on aircraft specific requirements and are not direct conversions } \\
\text { from inch-pound (English) dimensions. Inch-pound units are included only as a reference to the previous } \\
\text { standard. }\end{array}$} \\
\hline
\end{tabular}


Figure 12. Standard VFR Helipad for Army and Air Force (UFC 3-260-01, Fig. 4-4).
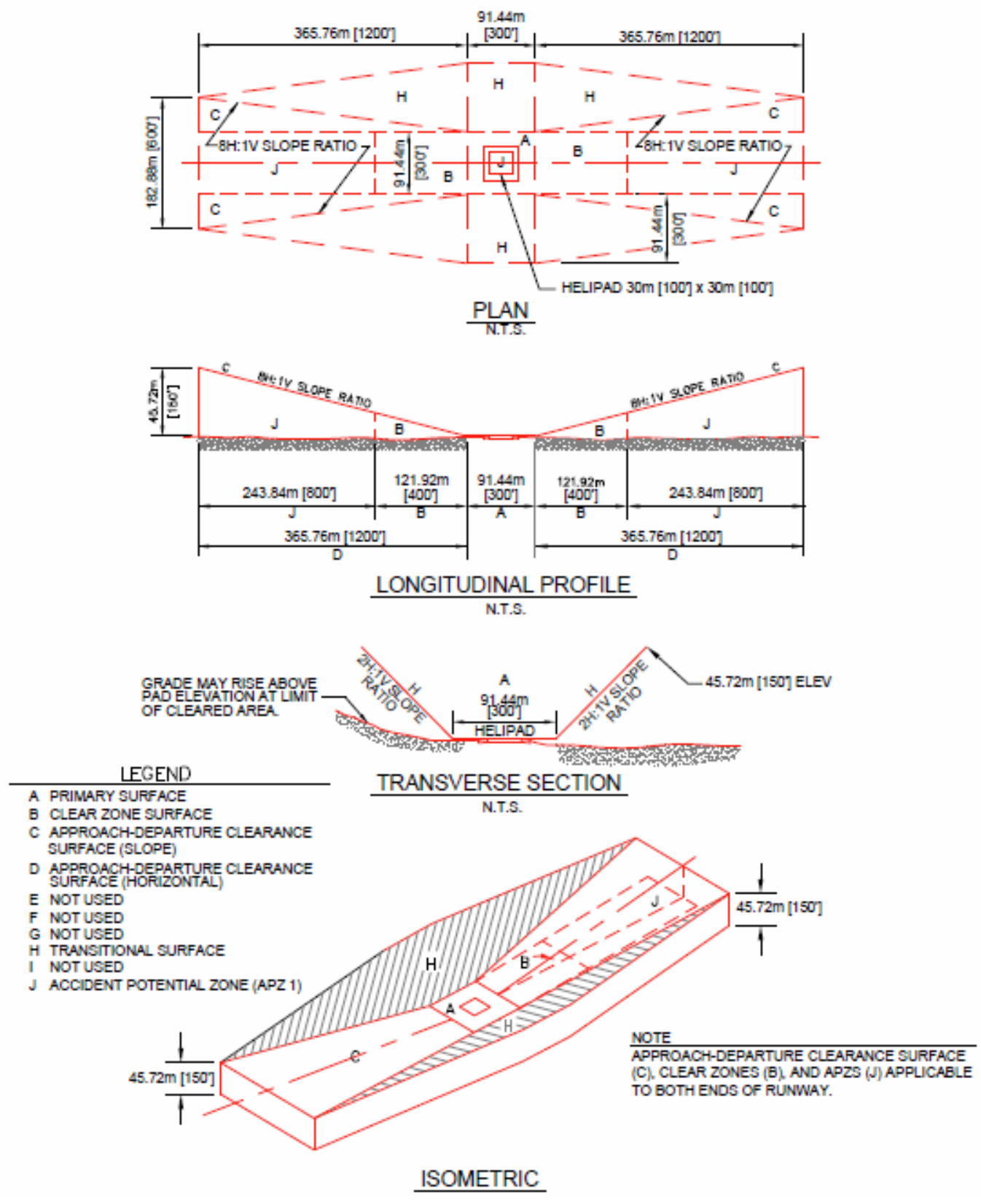
Figure 13. VFR Helipad for Army Air Force limited use (UFC 3-260-01, Fig. 4-5).
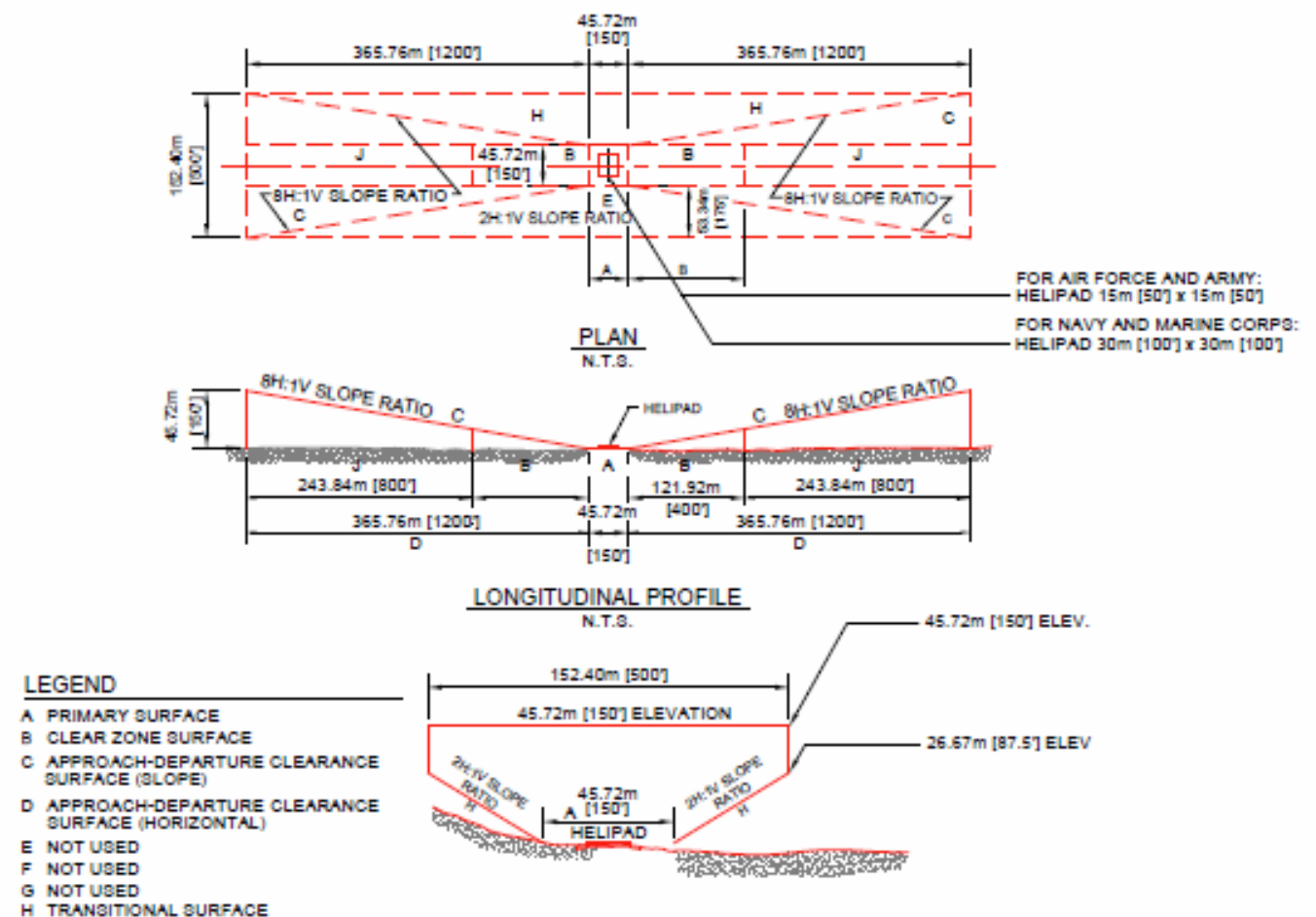

H TRANGITIONAL GURFACE

I NOT USED

J ACCIDENT POTENTIAL ZONE (APZ 1) $\frac{\text { TRANSVERSE SECTION }}{\text { N.T.S }}$

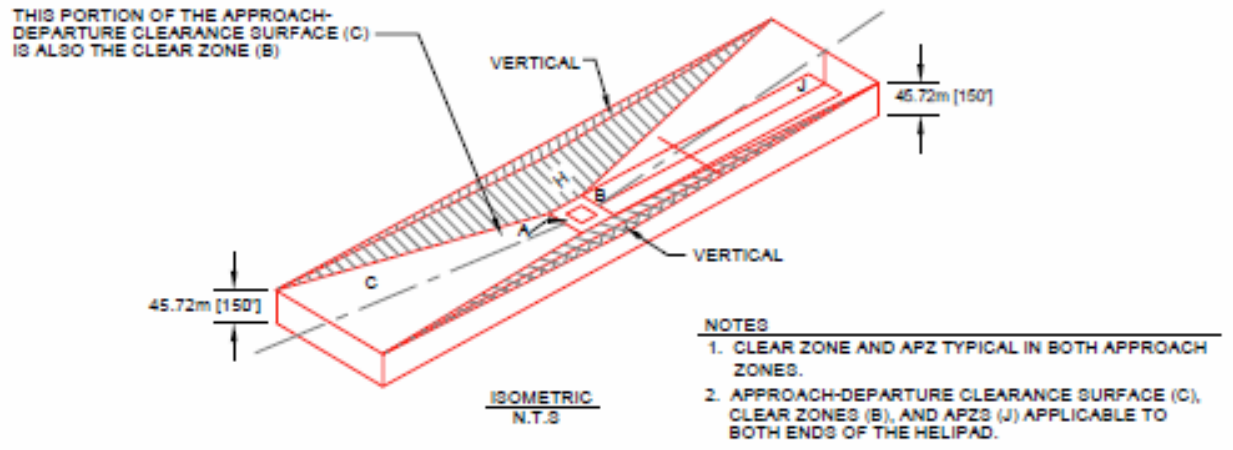


Figure 14. Standard IFR helipad (UFC 3-260-01, Fig. 4-6).

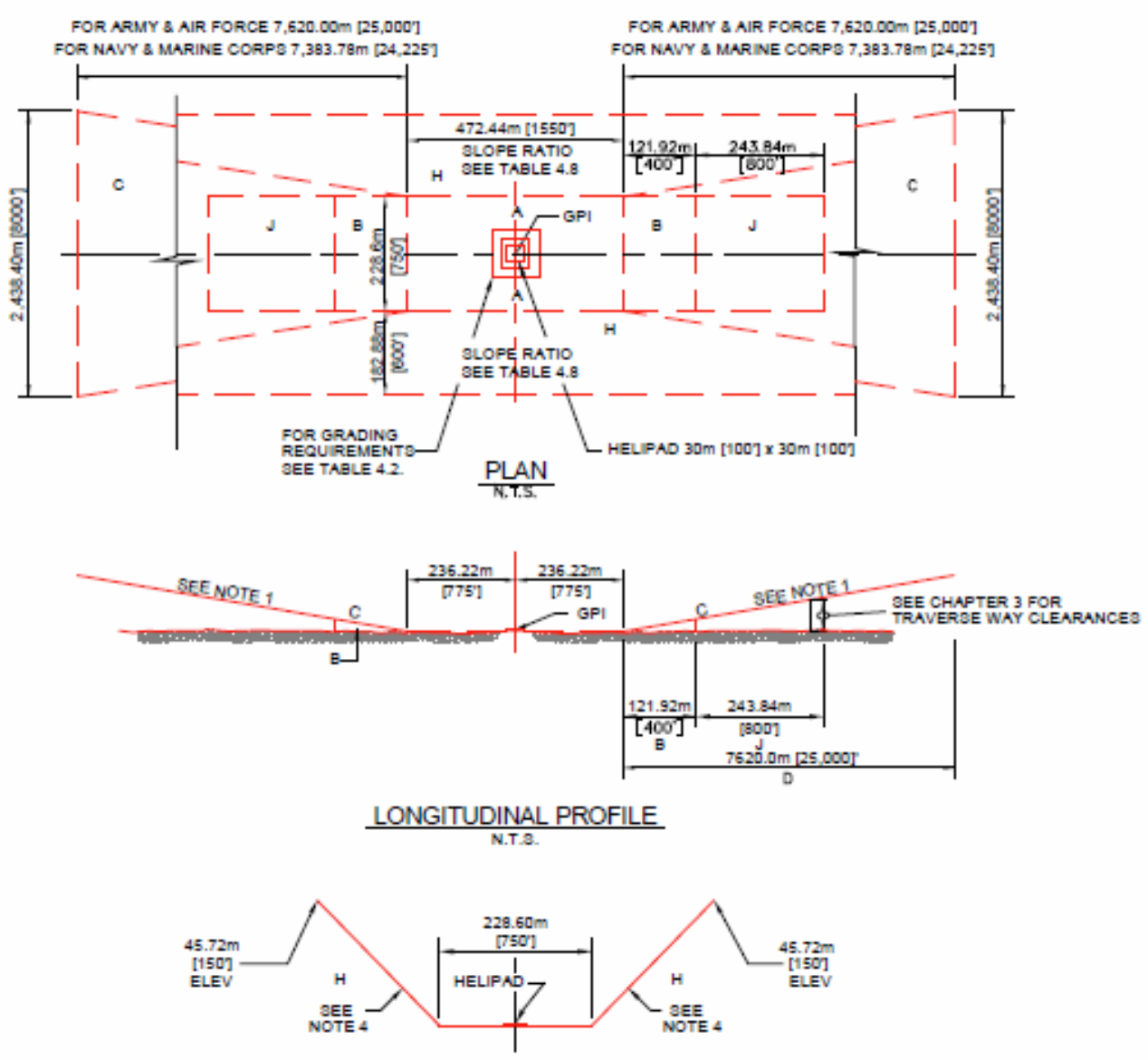

$\frac{\text { TRANSVERSE SECTION }}{\text { N.T. }}$

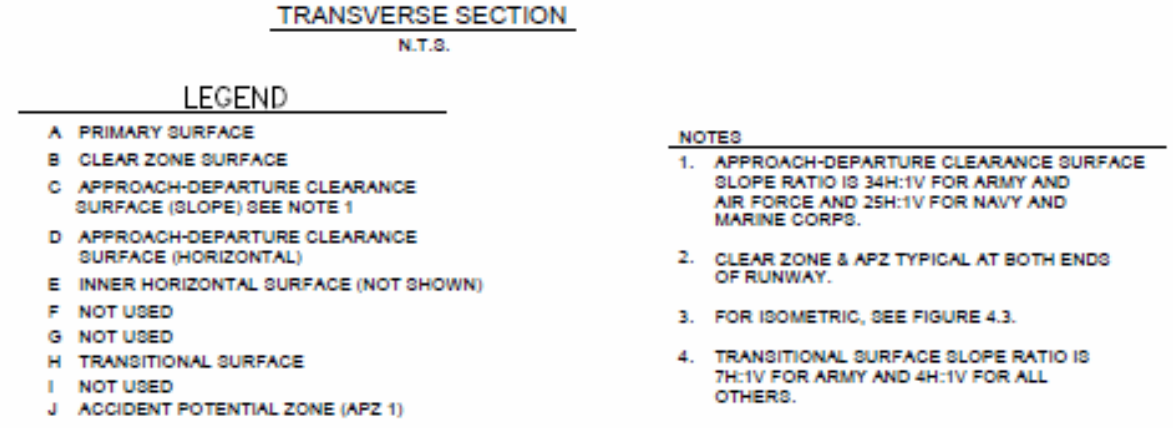

\subsection{Helipads-same-direction ingress/egress}

Helipads with same-direction ingress/ egress allow a helicopter pad to be located in a confined area where approaches and departures are made from only one direction. The approach may be either VFR or IFR. For the 
Air Force and Army, single-direction ingress/ egress VFR limited-use helipads are configured as shown in Figure 16 by using the criteria given in Table 19 and Table 23.

Table 19 presents dimensional criteria for VFR and IFR same-direction ingress/ egress helipads. Layout for VFR, VFR limited use, and IFR same-direction ingress/ egress helipads are illustrated in Figure 15, Figure 16, and Figure 17.

Figure 15. VFR Helipad with same direction ingress/egress (UFC 3-260-01, Fig. 4-7).

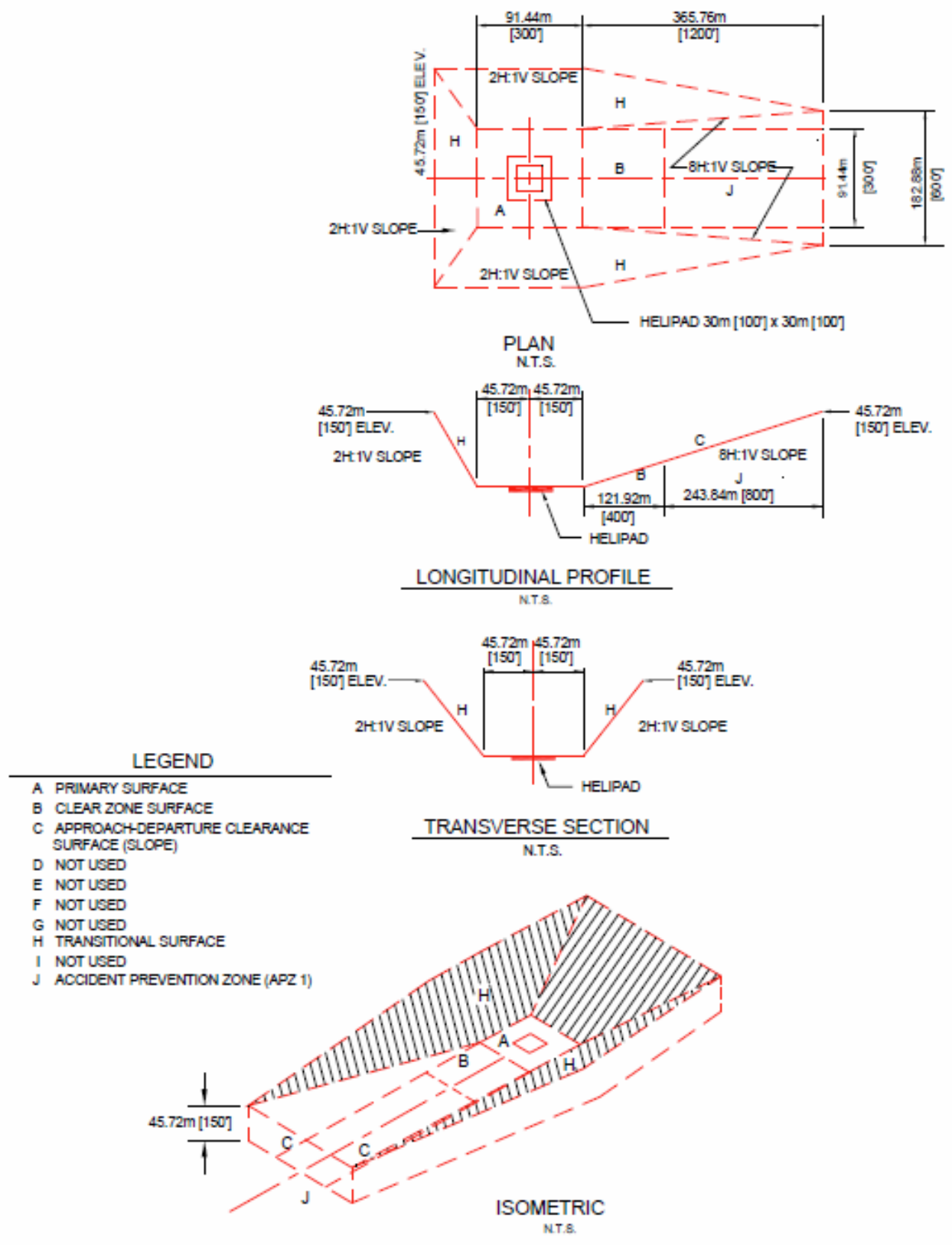


Figure 16. Army Air Force VFR limited used helipad with same direction ingress/egress (UFC 3-260-01, Fig. 4-8).

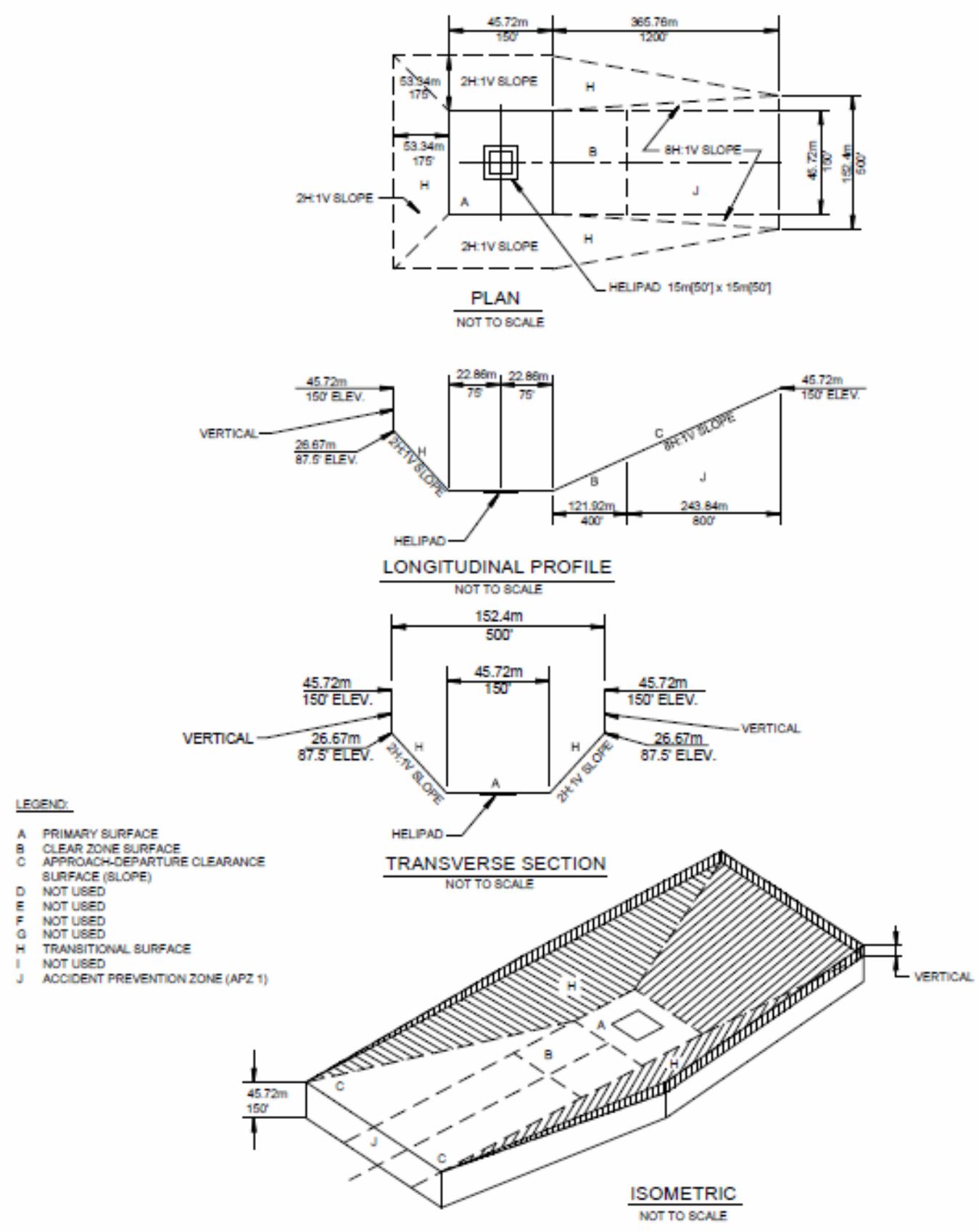


Figure 17. IFR Helipad with same direction ingress/egress (UFC 3-260-01, Fig. 4-9).

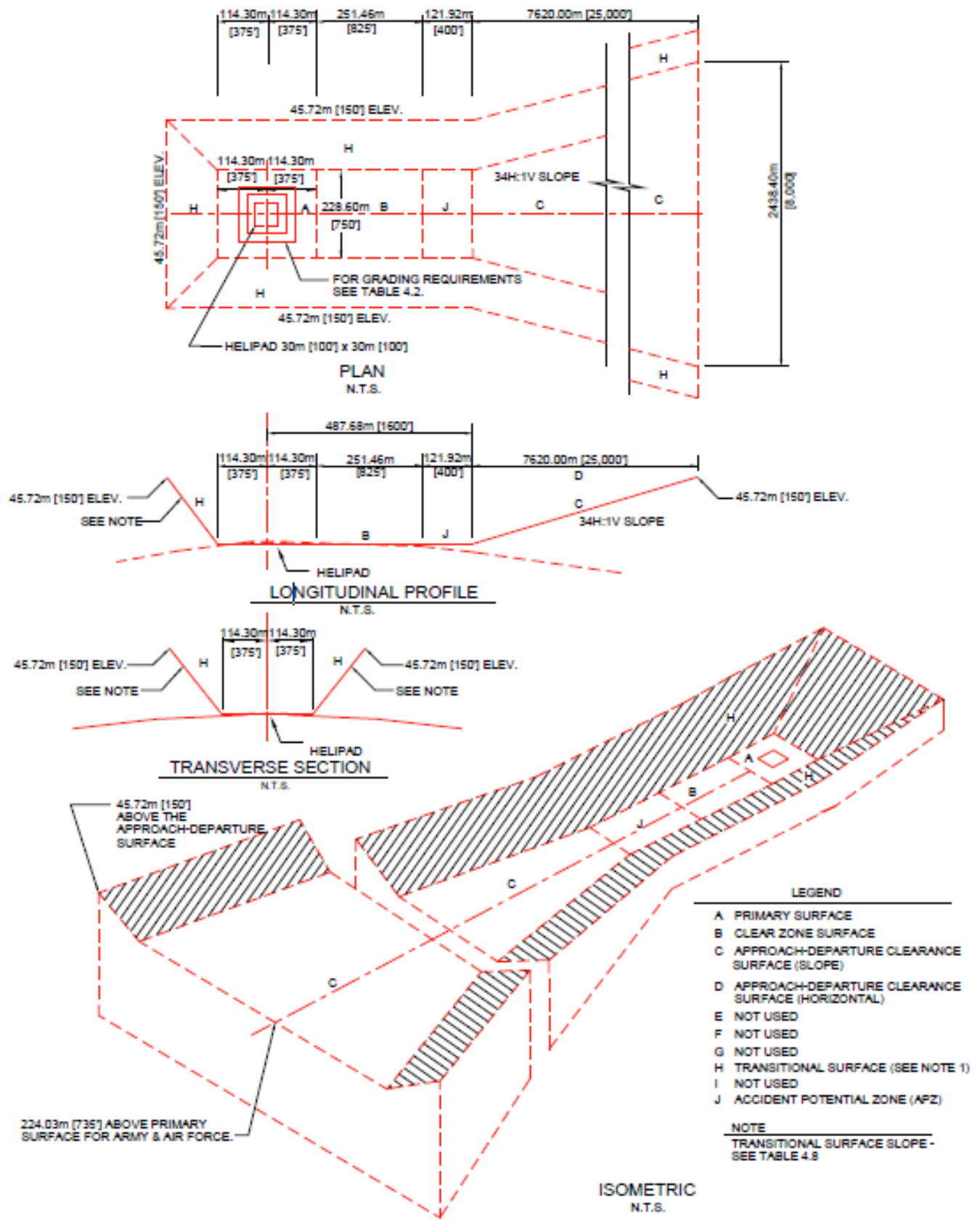

\subsection{Air Force helicopter slide areas (or "skid pads")}

VFR helicopter runway criteria described in Table 18 and shown in Figure 9 and Figure 12 (in terms of length, width, grade, and imaginary surfaces) are suitable for slide areas. The forces associated with helicopters landing at a small (but significant) rate of descent and between 10 and 30 knots of forward velocity require that slide-area surfaces have both good drainage 
and some resistance to rutting; however, these landing surfaces need not be paved.

\subsection{Shoulders for rotary-wing facilities}

Unprotected areas adjacent to runways and overruns are susceptible to erosion caused by rotor wash. The shoulder width for rotary-wing runways and helipads, shown in Table 20, includes both paved and unpaved shoulders. Paved shoulders are required adjacent to all helicopter operational surfaces, including runways, and helipads. The unpaved shoulder must be graded to prevent water from ponding on the adjacent paved area. The drop-off next to the paved area prevents turf, which may build up over the years, from ponding water. Figure 9 through Figure 17 illustrate rotarywing facility shoulders.

Table 20. Shoulders for rotary-wing facilities (UFC 3-260-01, Table 4-4).

\begin{tabular}{|c|c|c|c|}
\hline \multicolumn{4}{|c|}{ Shoulders for Rotary-Wing Facilities } \\
\hline No. & $\begin{array}{c}\text { Item } \\
\text { Description }\end{array}$ & Requirement & Remarks \\
\hline 1 & $\begin{array}{l}\text { Total width of } \\
\text { shoulders } \\
\text { (paved and unpaved) } \\
\text { adjacent to all } \\
\text { operational pavements }\end{array}$ & $7.5 \mathrm{~m}(25 \mathrm{ft})$ & $\begin{array}{l}\text { May be increased when necessary to } \\
\text { accommodate dual operations with } \\
\text { fixed-wing aircraft }\end{array}$ \\
\hline \multirow[t]{2}{*}{2} & $\begin{array}{l}\text { Paved shoulder width } \\
\text { next to all operational } \\
\text { pavements }\end{array}$ & $7.5 \mathrm{~m}(25 \mathrm{ft})$ & Army and Air Force \\
\hline & & $0 \mathrm{~m}(0 \mathrm{ft})$ & Navy and Marine Corps, except as noted \\
\hline 3 & Longitudinal grade & Variable & $\begin{array}{l}\text { Conform to the longitudinal grade of the } \\
\text { abutting primary pavement }\end{array}$ \\
\hline 4 & Transverse grade & $\begin{array}{l}2.0 \text { percent } \min \\
4.0 \text { percent } \max \end{array}$ & Slope downward from edge of pavement \\
\hline 5 & $\begin{array}{l}\text { Grade } \\
\text { (adjacent to paved } \\
\text { shoulder) }\end{array}$ & $\begin{array}{l}\text { (a) } 40 \text {-mm (1.5-in) drop-off at } \\
\text { edge of paved shoulder }+/- \\
13 \text { mm }(0.5 \text { in) } \\
\text { (b) minimum } 2 \text { percent, } \\
\text { maximum } 5 \text { percent within } \\
\text { the primary surface }\end{array}$ & $\begin{array}{l}\text { Primary surface and clear zone criteria apply } \\
\text { beyond this point. }\end{array}$ \\
\hline \multicolumn{4}{|c|}{ NOTES: } \\
\hline \multicolumn{4}{|c|}{$\begin{array}{l}\text { 1. Metric units apply to new airfield construction and, where practical, modification to existing airfields and } \\
\text { heliports, as discussed in paragraph } 1-4.4 \text {. } \\
\text { 2. The criteria in this manual are based on aircraft specific requirements and are not direct conversions from } \\
\text { inch-pound (English) dimensions. Inch-pound units are included only as a reference to the previous } \\
\text { standard. }\end{array}$} \\
\hline
\end{tabular}

\subsection{Overruns for rotary-wing runways}

Overruns are required at the end of all rotary-wing runways, and Table 21 shows the dimensional requirements. The pavement in the overrun is considered a paved shoulder. Figure 9 and Figure 10 illustrate rotary-wing overruns for runways. 
Table 21. Overruns for rotary-wing runways (UFC 3-260-01, Table 4-5).

\begin{tabular}{|c|c|c|c|}
\hline \multicolumn{4}{|c|}{ Overruns for Rotary-Wing Runways and Landing Lanes } \\
\hline \multicolumn{2}{|r|}{ Item } & \multirow[b]{2}{*}{ Requirement } & \multirow[b]{2}{*}{ Remarks } \\
\hline No. & Description & & \\
\hline 1 & $\begin{array}{l}\text { Total length } \\
\text { (paved and } \\
\text { unpaved) } \\
\end{array}$ & $23 \mathrm{~m}(75 \mathrm{ft})$ & \\
\hline 2 & $\begin{array}{l}\text { Paved length of } \\
\text { overrun }\end{array}$ & $7.5 \mathrm{~m}(25 \mathrm{ft})$ & Air Force and Army only \\
\hline 3 & Width & $38 \mathrm{~m}(125 \mathrm{ft})$ & $\begin{array}{l}\text { Width of runway plus paved shoulders } \\
\text { A minimum width of } 45 \mathrm{~m} \text { ( } 150 \mathrm{ft} \text { ) for airfields that } \\
\text { regularly accommodate } \mathrm{H}-53 \text { aircraft ( } 30-\mathrm{m} \text { (100-ft) } \\
\text { runway and } 7.5-\mathrm{m} \text { ( } 25 \text {-ft) shoulders) }\end{array}$ \\
\hline 4 & $\begin{array}{l}\text { Longitudinal } \\
\text { centerline grade }\end{array}$ & Max. 1.0 percent & $\begin{array}{l}\text { Changes in longitudinal grade in overrun or } \\
\text { between overrun and runway should not exceed } \\
0.167 \text { percent per } 30 \text { linear meters ( } 100 \text { linear } \\
\text { feet). }\end{array}$ \\
\hline 5 & $\begin{array}{l}\text { Transverse grade } \\
\text { (paved and } \\
\text { unpaved) }\end{array}$ & $\begin{array}{l}\text { Min. } 2.0 \text { percent } \\
\text { Max. } 3.0 \text { percent }\end{array}$ & Warp to meet runway and shoulder grades. \\
\hline
\end{tabular}

NOTES:

1. Metric units apply to new airfield construction and, where practical, modification to existing airfields and heliports, as discussed in paragraph 1-4.4.

2. The criteria in this manual are based on aircraft specific requirements and are not direct conversions from inch-pound (English) dimensions. Inch-pound units are included only as a reference to the previous standard.

3. Airfield and heliport imaginary surfaces and safe wingtip clearance dimensions are shown as a direct conversion from inch-pound to SI units.

\subsection{Clear zone and accident potential zone (APZ)}

The clear zone and APZ are areas on the ground, located under the rotarywing approach-departure surface. The clear zone and APZ are required for rotary-wing runways and helipads.

\subsubsection{Clear-zone land use}

The clear zone for rotary-wing facilities must be free of obstructions, both natural and manmade, and rough-graded to minimize damage to an aircraft that runs off or lands short of the end of the landing surface. In addition, the clear zone permits recovery of aircraft that are aborted during takeoff. The clear zone should be either owned or protected under a longterm lease. Land use for the clear-zone area for rotary-wing facilities corresponds to the clear-zone land-use criteria for fixed-wing airfields as defined for DoD Air Installation Compatible Use Zone (AICUZ) standards (DoD Instruction 4165.57) and as discussed in UFC 3-260-01(2008) Chapter 3 and Appendix B, Section 3. The DoD Instruction has been updated since the publication of the UFC. 


\subsubsection{Accident-potential zone}

Land use for the APZ area at rotary-wing facilities corresponds to the APZ land-use criteria for fixed-wing airfields as defined in DoD AICUZ standards and as discussed in Chapter 3 and Section 3 of Appendix B of UFC 3260-01 (2008). Ownership of the APZ is desirable but not required. If ownership is not possible, land use should be controlled through longterm lease agreements or local zoning ordinances.

\subsubsection{Dimensions}

Table 22 shows the dimensional requirements for the clear zone and APZ. These dimensions apply to rotary-wing runways and helipads, depending on whether they support VFR or IFR operations. Figure 9, Figure 10, and Figure 12 through Figure 17 show the layout of the clear zone and APZ.

Table 22. Rotary-wing runway clear zone and APZ (UFC 3-260-01, Table 4-6).

\begin{tabular}{|c|c|c|c|}
\hline \multicolumn{4}{|c|}{ Rotary-Wing Runway and Landing Lane Clear Zone and APZ ${ }^{12}$} \\
\hline \multicolumn{2}{|r|}{ Item } & \multirow[b]{2}{*}{ Requirement } & \multirow[b]{2}{*}{ Remarks } \\
\hline No. & Description & & \\
\hline 1 & Clear zone length & $\begin{array}{c}121.92 \mathrm{~m} \\
(400 \mathrm{ft})\end{array}$ & $\begin{array}{l}\text { Clear zone begins at the end of the primary } \\
\text { surface. }\end{array}$ \\
\hline \multirow[t]{2}{*}{2} & $\begin{array}{l}\text { Clear zone width (center width on } \\
\text { extended runway/landing lane } \\
\text { centerline) (corresponds to the } \\
\text { width of the primary surface) }\end{array}$ & $\begin{array}{l}91.44 \mathrm{~m} \\
(300 \mathrm{ft})\end{array}$ & $\begin{array}{l}\text { VFR rotary-wing runways and landing lanes } \\
\text { See note } 2 \text {. }\end{array}$ \\
\hline & & $\begin{array}{l}228.60 \mathrm{~m} \\
(750 \mathrm{ft})\end{array}$ & $\begin{array}{l}\text { IFR rotary-wing runways and landing lanes } \\
\text { See note } 2 \text {. }\end{array}$ \\
\hline 3 & $\begin{array}{l}\text { Grades in clear zone } \\
\text { in any direction }\end{array}$ & $\begin{array}{l}2.0 \text { percent } \\
\text { Min. } \\
5.0 \text { percent } \\
\text { Max. }\end{array}$ & $\begin{array}{l}\text { Clear zone only } \\
\text { Area to be free of obstructions. Rough-grade } \\
\text { and turf when required. }\end{array}$ \\
\hline 4 & APZ I length & $\begin{array}{c}243.84 \mathrm{~m} \\
(800 \mathrm{ft})\end{array}$ & See notes 2 and 3. \\
\hline \multirow[t]{2}{*}{5} & APZ I width & $\begin{array}{l}91.44 \mathrm{~m} \\
(300 \mathrm{ft})\end{array}$ & $\begin{array}{l}\text { VFR rotary-wing runways and landing lanes } \\
\text { See notes } 2 \text { and } 3 \text {. }\end{array}$ \\
\hline & & $\begin{array}{l}228.60 \mathrm{~m} \\
(750 \mathrm{ft})\end{array}$ & $\begin{array}{l}\text { IFR rotary-wing runways and landing lanes } \\
\text { See notes } 2 \text { and } 3 \text {. }\end{array}$ \\
\hline \multicolumn{4}{|c|}{ NOTES: } \\
\hline \multicolumn{4}{|c|}{$\begin{array}{l}\text { 1. The clear zone area for rotary wing runways and landing lanes corresponds to the clear zone land use } \\
\text { criteria for fixed-wing airfields as defined in DOD AICUZ standards and summarized in Appendix B, } \\
\text { Section 3. The remainder of the approach-departure zone corresponds to APZ I land use criteria similarly } \\
\text { defined. APZ II criteria is not applicable for rotary-wing aircraft. }\end{array}$} \\
\hline \multirow{2}{*}{\multicolumn{4}{|c|}{$\begin{array}{l}\text { 2. Exceptions to these widths are permissible based on individual Service analysis of highest accident } \\
\text { potential area for specific rotary-wing runway/landing lane use and acquisition constraints. } \\
\text { 3. No grading requirements for APZ I. }\end{array}$}} \\
\hline & & & \\
\hline \multicolumn{4}{|c|}{$\begin{array}{l}\text { 4. Metric units apply to new airfield construction and, where practical, modification to existing airfields } \\
\text { and heliports, as discussed in paragraph } 1-4.4 \text {. }\end{array}$} \\
\hline \multicolumn{4}{|c|}{$\begin{array}{l}\text { 5. The criteria in this manual are based on aircraft specific requirements and are not direct conversions from } \\
\text { inch-pound (English) dimensions. Inch-pound units are included only as a reference to the previous } \\
\text { standard. }\end{array}$} \\
\hline \multicolumn{4}{|c|}{$\begin{array}{l}\text { 6. Airfield and heliport imaginary surfaces and safe wingtip clearance dimensions are shown as a direct } \\
\text { conversion from inch-pound to SI units. }\end{array}$} \\
\hline
\end{tabular}




\subsection{Imaginary surface for rotary-wing runways and helipads}

Rotary-wing runways and helipads have imaginary surfaces similar to the imaginary surfaces for fixed-wing facilities. The imaginary surfaces are defined planes in space that establish clearance requirements for helicopter operations. An object, either manmade or natural, that projects through an imaginary surface plane is an obstruction to air navigation. Table 23, Table 24, Figure 9, and Figure 17 provide the layout of the rotary-wing airspace imaginary surfaces. Rotary-wing airspace imaginary surfaces are listed and defined here:

- Primary surface. Imaginary surface symmetrically centered on the runway, extending beyond the runway ends. The width and length depends on whether the runway is to accommodate VFR or IFR operations. The lateral clearance distance coincides with the width of the primary surface. The elevation of any point on the primary surface is the same as the elevation of the nearest point on the runway centerline.

- Approach-departure clearance surface (VFR, VFR limited use helipads, and IFR). Inclined plane or combined inclined and horizontal planes arranged symmetrically about the runway centerline extended. The first segment or the beginning of the inclined plane is coincident with the ends and edges of the primary surface and the elevation of the centerline at the runway end. This surface flares outward and upward from these points.

- Horizontal surface (IFR). An imaginary plane at $45.72 \mathrm{~m}$ (150 ft) above the established heliport or helipad elevation. The inner boundary intersects with the approach-departure clearance surface and the transitional surface. The outer boundary is formed by scribing an arc at the end of each runway and connecting the arcs with tangents or by scribing the arc about the center of the helipad. See Chapter 4 UFC 3-26001 for dimensions.

- Transitional surfaces. The imaginary plane that connect the primary surface and the approach-departure clearance surface to the horizontal surface or extends to a prescribed horizontal distance beyond the limits of the horizontal surface. Each surface extends outward and upward at a specified slope measured perpendicular to the runway centerline or helipad longitudinal centerline (or centerlines) extended. 
Table 23. Rotary-wing imaginary surfaces for VFR approaches

(UFC 3-260-01, Table 4-7).

\begin{tabular}{|c|c|c|c|c|c|c|}
\hline \multicolumn{7}{|c|}{ Rotary-Wing Imaginary Surface for VFR Approaches } \\
\hline & Item & & & & lipad & \multirow[b]{2}{*}{ Remarks } \\
\hline No. & Description & $\begin{array}{c}\text { Legend } \\
\text { in } \\
\text { Figures }\end{array}$ & $\begin{array}{c}\text { Helicopter } \\
\text { Runway and } \\
\text { Landing } \\
\text { Lane }\end{array}$ & $\begin{array}{l}\text { Air Force } \\
\text { and Army } \\
\text { VFR } \\
\text { Standard } \\
\end{array}$ & $\begin{array}{l}\text { Air Force and } \\
\text { Army VFR } \\
\text { Limited Use; } \\
\text { Navy and } \\
\text { Marine Corps } \\
\text { Standard } \\
\text { Helipad and } \\
\text { Hoverpoints }{ }^{1,2} \\
\end{array}$ & \\
\hline 1 & Primary surface width & A & $\begin{array}{l}91.44 \mathrm{~m} \\
(300 \mathrm{ft})\end{array}$ & $\begin{array}{l}91.44 \mathrm{~m} \\
(300 \mathrm{ft})\end{array}$ & $\begin{array}{l}45.72 \mathrm{~m} \\
(150 \mathrm{ft})\end{array}$ & $\begin{array}{l}\text { Centered on the } \\
\text { ground point of } \\
\text { intercept (GPI) }\end{array}$ \\
\hline 2 & Primary surface length & A & \begin{tabular}{|c|} 
Runway or \\
landing lane \\
length plus \\
$22.86 \mathrm{~m}$ \\
$(75 \mathrm{ft})$ at each \\
end \\
\end{tabular} & $\begin{array}{l}91.44 \mathrm{~m} \\
(300 \mathrm{ft}) \\
\text { centered on } \\
\text { facility }\end{array}$ & $\begin{array}{l}45.72 \mathrm{~m} \\
(150 \mathrm{ft}) \\
\text { centered on } \\
\text { facility }\end{array}$ & $\begin{array}{l}\text { Runway or landing } \\
\text { lane length plus } \\
30.48 \mathrm{~m} \text { (100 ft) at } \\
\text { each end for Navy } \\
\text { and Marine Corps } \\
\text { facilities }\end{array}$ \\
\hline 3 & $\begin{array}{l}\text { Primary surface } \\
\text { elevation }\end{array}$ & A & $\begin{array}{l}\text { The elevation o } \\
\text { surface is the s: } \\
\text { nearest point or } \\
\text { established ele }\end{array}$ & $\begin{array}{l}\text { of any point on th } \\
\text { same as the elev } \\
\text { on the runway ce } \\
\text { evation of the lan }\end{array}$ & $\begin{array}{l}\text { ee primary } \\
\text { ation of the } \\
\text { nterline or at the } \\
\text { ding surface. }\end{array}$ & \\
\hline 4 & Clear zone surface & $\mathrm{B}$ & See Table 4-6 & See Table 4-2 & See Table 4-2 & \\
\hline 5 & $\begin{array}{l}\text { Start of } \\
\text { approach-departure } \\
\text { surface }\end{array}$ & $\mathrm{C}$ & \begin{tabular}{|c|}
$22.86 \mathrm{~m}$ \\
$(75 \mathrm{ft})$ \\
from end of \\
runway or \\
landing lane \\
\end{tabular} & $\begin{array}{l}45.72 \mathrm{~m} \\
(150 \mathrm{ft}) \\
\text { from GPI }\end{array}$ & $\begin{array}{l}22.86 \mathrm{~m} \\
(75 \mathrm{ft}) \\
\text { from GPI }\end{array}$ & \\
\hline 6 & $\begin{array}{l}\text { Length of sloped portion } \\
\text { of approach-departure } \\
\text { surface }\end{array}$ & C & $\begin{array}{l}365.76 \mathrm{~m} \\
(1,200 \mathrm{ft})\end{array}$ & $\begin{array}{l}365.76 \mathrm{~m} \\
(1,200 \mathrm{ft})\end{array}$ & $\begin{array}{l}365.76 \mathrm{~m} \\
(1,200 \mathrm{ft})\end{array}$ & $\begin{array}{l}\text { Measured } \\
\text { horizontally. }\end{array}$ \\
\hline 7 & $\begin{array}{l}\text { Slope of } \\
\text { approach-departure } \\
\text { surface }\end{array}$ & C & $8: 1$ & 8:1 & $8: 1$ & $\begin{array}{l}\text { Slope ratio is } \\
\text { horizontal to vertical. } \\
8: 1 \text { is } 8 \mathrm{~m}(\mathrm{ft}) \\
\text { horizontal to } 1 \mathrm{~m} \text { (ft) } \\
\text { vertical. }\end{array}$ \\
\hline 8 & $\begin{array}{l}\text { Width of sloped portion } \\
\text { of approach-departure } \\
\text { surface at start of } \\
\text { sloped portion }\end{array}$ & c & $\begin{array}{l}91.44 \mathrm{~m} \\
(300 \mathrm{ft})\end{array}$ & $\begin{array}{l}91.44 \mathrm{~m} \\
(300 \mathrm{ft})\end{array}$ & $\begin{array}{l}45.72 \mathrm{~m} \\
(150 \mathrm{ft})\end{array}$ & $\begin{array}{l}\text { Centered on the } \\
\text { extended center-line, } \\
\text { and is the same } \\
\text { width as the primary } \\
\text { surface. }\end{array}$ \\
\hline 9 & $\begin{array}{l}\text { Width of sloped portion } \\
\text { of apprcach- departure } \\
\text { surface at end of } \\
\text { sloped portion }\end{array}$ & C & $\begin{array}{c}\frac{182.88 \mathrm{~m}}{(600 \mathrm{ft})} \\
\text {. }\end{array}$ & $\begin{array}{c}182.88 \mathrm{~m} \\
(600 \mathrm{ft})\end{array}$ & $\begin{array}{c}152.40 \mathrm{~m} \\
(500 \mathrm{ft})\end{array}$ & $\begin{array}{l}\text { Centered on the } \\
\text { extended center-line }\end{array}$ \\
\hline
\end{tabular}


Table 23 (cont.). Rotary-wing imaginary surfaces for VFR approaches (UFC 3-260-01, Table 4-7).

\begin{tabular}{|c|c|c|c|c|c|c|}
\hline \multicolumn{7}{|c|}{ Rotary-Wing Imaginary Surface for VFR Approaches } \\
\hline No. & \begin{tabular}{|l} 
Item \\
Description
\end{tabular} & $\begin{array}{l}\text { Legend } \\
\text { in } \\
\text { Figures }\end{array}$ & $\begin{array}{c}\text { Helicopter } \\
\text { Runway and } \\
\begin{array}{c}\text { Landing } \\
\text { Lane }\end{array} \\
\end{array}$ & $\begin{array}{l}\text { Air Force } \\
\text { and Army } \\
\text { VFR } \\
\text { Standard } \\
\end{array}$ & $\begin{array}{l}\text { Aipad Force and } \\
\text { Army VFR } \\
\text { Limited Use; } \\
\text { Navy and } \\
\text { Marine Corps } \\
\text { Standard } \\
\text { Helipad and } \\
\text { Hoverpoints }\end{array}$ & Remarks \\
\hline 10 & $\begin{array}{l}\text { Elevation of } \\
\text { approach-departure } \\
\text { surface at start of } \\
\text { sloped portion }\end{array}$ & $\mathrm{C}$ & $\begin{array}{l}0 \mathrm{~m} \\
(0 \mathrm{ft})\end{array}$ & $\begin{array}{l}0 \mathrm{~m} \\
(0 \mathrm{ft})\end{array}$ & $\begin{array}{l}0 \mathrm{~m} \\
(0 \mathrm{ft})\end{array}$ & $\begin{array}{l}\text { Above the } \\
\text { established elevation } \\
\text { of the landing } \\
\text { surface. }\end{array}$ \\
\hline 11 & $\begin{array}{l}\text { Elevation of } \\
\text { approach-departure } \\
\text { surface at end of } \\
\text { sloped portion }\end{array}$ & $\mathrm{C}$ & $\begin{array}{l}45.72 \mathrm{~m} \\
(150 \mathrm{ft})\end{array}$ & $\begin{array}{l}45.72 \mathrm{~m} \\
(150 \mathrm{ft})\end{array}$ & $\begin{array}{l}45.72 \mathrm{~m} \\
(150 \mathrm{ft})\end{array}$ & $\begin{array}{l}\text { Above the } \\
\text { established elevation } \\
\text { of the landing } \\
\text { surface. }\end{array}$ \\
\hline 12 & $\begin{array}{l}\text { Length of } \\
\text { approach-departure } \\
\text { zone }\end{array}$ & $\mathrm{D}$ & $\begin{array}{l}365.76 \mathrm{~m} \\
(1,200 \mathrm{ft})\end{array}$ & $\begin{array}{l}365.76 \mathrm{~m} \\
(1,200 \mathrm{ft})\end{array}$ & $\begin{array}{l}365.76 \mathrm{~m} \\
(1,200 \mathrm{ft})\end{array}$ & $\begin{array}{l}\text { Measured } \\
\text { horizontally from the } \\
\text { end of the primary } \\
\text { surface and is the } \\
\text { same length as the } \\
\text { approach-departure } \\
\text { clearance surface } \\
\text { length }\end{array}$ \\
\hline 13 & $\begin{array}{l}\text { Start of } \\
\text { approach-departure } \\
\text { zone }\end{array}$ & $\mathrm{D}$ & \begin{tabular}{|c}
$22.86 \mathrm{~m}$ \\
$(75 \mathrm{ft})$ from \\
end of runway
\end{tabular} & $\begin{array}{l}45.72 \mathrm{~m} \\
\text { (150 ft) from } \\
\text { center of } \\
\text { helipad }\end{array}$ & $\begin{array}{l}22.86 \mathrm{~m} \\
(75 \mathrm{ft}) \text { from } \\
\text { center of } \\
\text { helipad }\end{array}$ & $\begin{array}{l}\text { Starts at the end of } \\
\text { the primary surface }\end{array}$ \\
\hline 14 & $\begin{array}{l}\text { Transitional surface } \\
\text { slope }\end{array}$ & $\mathrm{H}$ & $\begin{array}{l}2 \mathrm{H}: 1 \mathrm{~V} \\
\text { See } \\
\text { remark } 1\end{array}$ & $\begin{array}{c}2 \mathrm{H}: 1 \mathrm{~V} \\
\text { See } \\
\text { remark } 1\end{array}$ & $\begin{array}{c}2 \mathrm{H}: 1 \mathrm{~V} \\
\text { See } \\
\text { remark } 2\end{array}$ & $\begin{array}{l}\text { (1) The transitional } \\
\text { surface starts at the } \\
\text { lateral edges of the } \\
\text { primary surface and } \\
\text { the approach- } \\
\text { departure clearance } \\
\text { surface. It continues } \\
\text { outward and upward } \\
\text { at the prescribed } \\
\text { slope to an elevation } \\
\text { of } 45.72 \mathrm{~m} \text { (150 ft) } \\
\text { above the } \\
\text { established airfield } \\
\text { elevation. } \\
\text { (2) The transitional } \\
\text { surface starts at the } \\
\text { lateral edges of the } \\
\text { primary surface and } \\
\text { the approach- } \\
\text { departure clearance } \\
\text { surface. It continues } \\
\text { outward and upward } \\
\text { at the prescribed } \\
\text { slope to an elevation } \\
\text { of } 26.67 \mathrm{~m} \text { ( } 87.5 \mathrm{ft} \text { ) } \\
\text { above the } \\
\text { established airfield } \\
\text { elevation. It then } \\
\text { rises vertically to an } \\
\text { elevation of } 45.7 \mathrm{~m} \\
\text { (150 ft) above the } \\
\text { established airfield } \\
\text { elevation. } \\
\text { See figures } 4-5 \text { and } \\
4-10 \text { for the shape of } \\
\text { transitional surfaces. }\end{array}$ \\
\hline 15 & Horizontal surface & G & Not required & Not required & Not required & \\
\hline
\end{tabular}

NOTES:

1. The Navy and Marine Corps do not have criteria for same direction ingress/egress.

2. The Army does not have VFR rotary-wing runways or landing lanes.

3. Metric units apply to new airfield construction and, where practical, modification to existing airfields and heliports, as discussed in paragraph 1-4.4

4. The criteria in this manual are based on aircraft specific requirements and are not direct conversions from inch-pound (English) dimensions. Inch-pound units are included only as a reference to the previous standard.

5. Airfield and heliport imaginary surfaces and safe wingtip clearance dimensions are shown as a direct conversion from inch-pound to SI units. 
Table 24. Rotary-wing imaginary surfaces for IFR approaches (UFC 3-260-01, Table 4-8).

\begin{tabular}{|c|c|c|c|c|c|c|}
\hline \multicolumn{7}{|c|}{ Rotary-Wing Imaginary Surfaces for IFR Approaches } \\
\hline \multicolumn{2}{|r|}{ Item } & \multirow{2}{*}{$\begin{array}{l}\text { Legend } \\
\text { in } \\
\text { Figures }\end{array}$} & \multirow{2}{*}{\begin{tabular}{c|} 
Helicopter \\
Runway \\
and \\
Landing Lanes
\end{tabular}} & \multicolumn{2}{|c|}{ Helipad } & \multirow[b]{2}{*}{ Remarks } \\
\hline No. & Description & & & Standard & $\begin{array}{l}\text { Same Direction } \\
\text { Ingress/Egress }\end{array}$ & \\
\hline 1 & $\begin{array}{l}\text { Primary } \\
\text { surface width }\end{array}$ & A & $\begin{array}{c}228.60 \mathrm{~m} \\
(750 \mathrm{ft})\end{array}$ & $\begin{array}{c}228.60 \mathrm{~m} \\
(750 \mathrm{ft})\end{array}$ & $\begin{array}{c}228.60 \mathrm{~m} \\
(750 \mathrm{ft})\end{array}$ & Centered on helipad \\
\hline 2 & $\begin{array}{l}\text { Primary } \\
\text { surface length }\end{array}$ & A & $\begin{array}{c}\text { The greater } \\
\text { distance of. } \\
\text { runway or } \\
\text { landing lane } \\
\text { length plus } \\
60.96 \mathrm{~m}(200 \mathrm{ft}) \\
\text { at each end; or } \\
510.54 \mathrm{~m} \\
(1,675 \mathrm{ft})\end{array}$ & $\begin{array}{l}472.44 \mathrm{~m} \\
(1,550 \mathrm{ft}) \\
\text { centered } \\
\text { on GPI }\end{array}$ & $\begin{array}{l}114.3 \mathrm{~m} \\
(375 \mathrm{ft}) \\
\text { centered on } \\
\text { GPI }\end{array}$ & \\
\hline 3 & \begin{tabular}{|l|} 
Primary \\
surface \\
elevation
\end{tabular} & A & \multicolumn{3}{|c|}{$\begin{array}{l}\text { The elevation of any point on the primary surface is the } \\
\text { same as the elevation of the nearest point on the } \\
\text { runway or landing lane centerline or established } \\
\text { elevation of the helipad. }\end{array}$} & \\
\hline 4 & $\begin{array}{l}\text { Clear zone } \\
\text { surface }\end{array}$ & B & $\begin{array}{c}\text { See } \\
\text { Table 4-6 }\end{array}$ & $\begin{array}{c}\text { See } \\
\text { Table 4-2 }\end{array}$ & $\begin{array}{c}\text { See } \\
\text { Table 4-2 }\end{array}$ & \\
\hline \multirow[t]{3}{*}{5} & $\begin{array}{l}\text { Start of } \\
\text { approach- } \\
\text { departure } \\
\text { surface }\end{array}$ & C & $\begin{array}{c}\text { Begins } 60.96 \mathrm{~m} \\
\text { (200 ft) feet } \\
\text { beyond the end of } \\
\text { runway, } \\
\text { coincident with } \\
\text { end of primary } \\
\text { surface } \\
\end{array}$ & \begin{tabular}{|c|}
$236.22 \mathrm{~m}$ \\
$(775 \mathrm{ft})$ \\
from GPI
\end{tabular} & $\begin{array}{l}487.68 \mathrm{~m} \\
(1,600 \mathrm{ft}) \\
\text { from GPI }\end{array}$ & $\begin{array}{l}\text { Army and Air Force } \\
\text { facilities }\end{array}$ \\
\hline & & & $\begin{array}{c}236.22 \mathrm{~m} \\
(775 \mathrm{ft}) \\
\text { from GPI. }\end{array}$ & \begin{tabular}{|c|}
$236.22 \mathrm{~m}$ \\
$(775 \mathrm{ft})$ \\
from $\mathrm{GPI}$. \\
\end{tabular} & $\mathrm{N} / \mathrm{A}$ & $\begin{array}{l}\text { Navy and Marine Corps } \\
\text { facilities }\end{array}$ \\
\hline & & & $\begin{array}{c}\text { See } \\
\text { Remarks }\end{array}$ & $\begin{array}{c}\text { See } \\
\text { Remarks }\end{array}$ & $\begin{array}{c}\text { See } \\
\text { Remarks }\end{array}$ & $\begin{array}{l}\text { Starts at the end of the } \\
\text { primary surface }\end{array}$ \\
\hline \multirow[t]{3}{*}{6} & $\begin{array}{l}\text { Length of } \\
\text { sloped portion } \\
\text { of approach- } \\
\text { departure } \\
\text { surface }\end{array}$ & C & $\begin{array}{l}7,620.00 \mathrm{~m} \\
(25,000 \mathrm{ft})\end{array}$ & $\begin{array}{l}7,620.00 \mathrm{~m} \\
(25,000 \mathrm{ft})\end{array}$ & $\begin{array}{l}7,620.00 \mathrm{~m} \\
(25,000 \mathrm{ft})\end{array}$ & $\begin{array}{l}\text { Army and Air Force } \\
\text { facilities }\end{array}$ \\
\hline & & & $\begin{array}{l}7,383.78 \mathrm{~m} \\
(24,225 \mathrm{ft})\end{array}$ & \begin{tabular}{|l|}
$7,383.78 \mathrm{~m}$ \\
$(24,225 \mathrm{ft})$ \\
\end{tabular} & N/A & $\begin{array}{l}\text { Navy and Marine Corps } \\
\text { facilities }\end{array}$ \\
\hline & & & $\begin{array}{c}\text { See } \\
\text { Remarks }\end{array}$ & $\begin{array}{c}\text { See } \\
\text { Remarks }\end{array}$ & $\begin{array}{c}\text { See } \\
\text { Remarks }\end{array}$ & Measured horizontally \\
\hline 7 & $\begin{array}{l}\text { Slope of } \\
\text { approach- } \\
\text { departure } \\
\text { surface }\end{array}$ & $\mathrm{C}$ & $34: 1$ & $34: 1$ & $34: 1$ & $\begin{array}{l}\text { Army and Air Force } \\
\text { Facilities }\end{array}$ \\
\hline
\end{tabular}


Table 24 (cont.). Rotary-wing imaginary surfaces for IFR approaches (UFC 3-260-01, Table 4-8).

\begin{tabular}{|c|c|c|c|c|c|c|}
\hline \multicolumn{7}{|c|}{ Rotary-Wing Imaginary Surfaces for IFR Approaches } \\
\hline No. & $\begin{array}{l}\text { Item } \\
\text { Description }\end{array}$ & $\begin{array}{c}\text { Legend } \\
\text { in } \\
\text { Figures }\end{array}$ & $\begin{array}{c}\text { Helicopter } \\
\text { Runway } \\
\text { and } \\
\text { Landing Lanes } \\
\end{array}$ & Standard & $\begin{array}{l}\text { Helipad } \\
\begin{array}{l}\text { Same Direction } \\
\text { Ingress/Egress }\end{array}\end{array}$ & Remarks \\
\hline & & & & Standard & $\begin{array}{c}\text { Air Force and Army } \\
\text { unidirectional } \\
\text { ingress/egress; } \\
\text { See Remarks. }\end{array}$ & $\begin{array}{l}\text { Navy and Marine Corps do } \\
\text { not have criteria for } \\
\text { unidirectional } \\
\text { ingress/egress. }\end{array}$ \\
\hline & & & $25: 1$ & $25: 1$ & $\mathrm{~N} / \mathrm{A}$ & $\begin{array}{l}\text { Navy and Marine Corps } \\
\text { facilities }\end{array}$ \\
\hline & & & $\begin{array}{c}\text { See } \\
\text { Remarks }\end{array}$ & $\begin{array}{c}\text { See } \\
\text { Remarks }\end{array}$ & $\begin{array}{c}\text { See } \\
\text { Remarks }\end{array}$ & $\begin{array}{l}\text { Slope ratio is horizontal to } \\
\text { vertical. } \\
34: 1 \text { is } 34 \mathrm{~m} \text { (ft) horizontal } \\
\text { to } 1 \mathrm{~m} \text { (ft) vertical. }\end{array}$ \\
\hline \multirow[t]{3}{*}{8} & $\begin{array}{l}\text { Width of } \\
\text { approach- } \\
\text { departure } \\
\text { surface at } \\
\text { start of sloped } \\
\text { portion }\end{array}$ & $\mathrm{C}$ & $\begin{array}{c}228.60 \mathrm{~m} \\
(750 \mathrm{ft})\end{array}$ & $\begin{array}{l}228.60 \mathrm{~m} \\
(750 \mathrm{ft})\end{array}$ & $\begin{array}{l}228.60 \mathrm{~m} \\
(750 \mathrm{ft})\end{array}$ & $\begin{array}{l}\text { Army and Air Force } \\
\text { facilities }\end{array}$ \\
\hline & & & $\begin{array}{c}228.60 \mathrm{~m} \\
(750 \mathrm{ft})\end{array}$ & $\begin{array}{l}228.60 \mathrm{~m} \\
(750 \mathrm{ft})\end{array}$ & $\mathrm{N} / \mathrm{A}$ & $\begin{array}{l}\text { Navy and Marine Corps } \\
\text { facilities }\end{array}$ \\
\hline & & & See Remarks & $\begin{array}{c}\text { See } \\
\text { Remarks }\end{array}$ & See Remarks & $\begin{array}{l}\text { Centered on the extended } \\
\text { centerline and is the same } \\
\text { width as the primary } \\
\text { surface }\end{array}$ \\
\hline \multirow[t]{3}{*}{9} & $\begin{array}{l}\text { Width of } \\
\text { approach- } \\
\text { departure } \\
\text { surface at end } \\
\text { of sloped } \\
\text { portion }\end{array}$ & C & $\begin{array}{l}2,438.60 \mathrm{~m} \\
(8,000 \mathrm{ft})\end{array}$ & $\begin{array}{c}2,438.60 \mathrm{~m} \\
(8,000 \mathrm{ft})\end{array}$ & $\begin{array}{l}2,438.60 \mathrm{~m} \\
(8,000 \mathrm{ft})\end{array}$ & $\begin{array}{l}\text { Army and Air Force } \\
\text { facilities }\end{array}$ \\
\hline & & & $\begin{array}{c}2,438.60 \mathrm{~m} \\
(8,000 \mathrm{ft})\end{array}$ & $\begin{array}{l}2,438.60 \mathrm{~m} \\
(8,000 \mathrm{ft})\end{array}$ & N/A & $\begin{array}{l}\text { Navy and Marine Corps } \\
\text { facilities }\end{array}$ \\
\hline & & & $\begin{array}{c}\text { See } \\
\text { Remarks }\end{array}$ & $\begin{array}{c}\text { See } \\
\text { Remarks }\end{array}$ & $\begin{array}{c}\text { See } \\
\text { Remarks }\end{array}$ & $\begin{array}{l}\text { Centered on the extended } \\
\text { centerline }\end{array}$ \\
\hline \multirow[t]{3}{*}{10} & $\begin{array}{l}\text { Elevation of } \\
\text { approach- } \\
\text { departure } \\
\text { surface at } \\
\text { start of sloped } \\
\text { portion }\end{array}$ & C & $\begin{array}{l}0 \mathrm{~m} \\
(0 \mathrm{ft})\end{array}$ & $\begin{array}{l}0 \mathrm{~m} \\
(0 \mathrm{ft})\end{array}$ & $\begin{array}{l}0 \mathrm{~m} \\
(0 \mathrm{ft})\end{array}$ & $\begin{array}{l}\text { Army and Air Force } \\
\text { facilities }\end{array}$ \\
\hline & & & $\begin{array}{l}0 \mathrm{~m} \\
(0 \mathrm{ft})\end{array}$ & $\begin{array}{l}0 \mathrm{~m} \\
(0 \mathrm{ft})\end{array}$ & $\mathrm{N} / \mathrm{A}$ & $\begin{array}{l}\text { Navy and Marine Corps } \\
\text { facilities }\end{array}$ \\
\hline & & & $\begin{array}{c}\text { See } \\
\text { Remarks }\end{array}$ & $\begin{array}{c}\text { See } \\
\text { Remarks }\end{array}$ & $\begin{array}{c}\text { See } \\
\text { Remarks }\end{array}$ & $\begin{array}{l}\text { Above the established } \\
\text { elevations of the landing } \\
\text { surface }\end{array}$ \\
\hline
\end{tabular}


Table 24 (cont.). Rotary-wing imaginary surfaces for IFR approaches (UFC 3-260-01, Table 4-8).

\begin{tabular}{|c|c|c|c|c|c|c|}
\hline \multicolumn{7}{|c|}{ Rotary-Wing Imaginary Surfaces for IFR Approaches } \\
\hline No. & $\begin{array}{l}\text { Item } \\
\text { Description }\end{array}$ & \multirow[t]{2}{*}{$\begin{array}{l}\text { Legend } \\
\text { in } \\
\text { Figures }\end{array}$} & \multirow[t]{2}{*}{$\begin{array}{l}\text { Helicopter } \\
\text { Runway } \\
\text { and } \\
\text { Landing Lanes } \\
\end{array}$} & \multicolumn{2}{|c|}{\begin{tabular}{c|c}
\multicolumn{2}{c}{ Helipad } \\
& $\begin{array}{l}\text { Same Direction } \\
\text { Standard }\end{array}$ \\
Ingress/Egress
\end{tabular}} & Remarks \\
\hline & & & & Standard & $\begin{array}{l}\text { Air Force and Army } \\
\text { unidirectional } \\
\text { ingress/egress; } \\
\text { See Remarks. }\end{array}$ & $\begin{array}{l}\text { Navy and Marine Corps do } \\
\text { not have criteria for } \\
\text { unidirectional } \\
\text { ingress/egress. }\end{array}$ \\
\hline \multirow[t]{3}{*}{11} & $\begin{array}{l}\text { Elevation of } \\
\text { approach- } \\
\text { departure } \\
\text { clearance } \\
\text { surface at end } \\
\text { of sloped } \\
\text { portion } \\
\end{array}$ & $\mathrm{C}$ & \multicolumn{3}{|c|}{$\begin{array}{c}224.03 \mathrm{~m} \\
(735 \mathrm{ft})\end{array}$} & Air Force and Army \\
\hline & & & $295.35 \mathrm{~m}(\mathrm{~S}$ & $969 \mathrm{ft})$ & N/A & Navy and Marine Corps \\
\hline & & & \multicolumn{3}{|c|}{ See Remarks } & $\begin{array}{l}\text { Above the established } \\
\text { elevation of the landing } \\
\text { surface }\end{array}$ \\
\hline \multirow[t]{5}{*}{12} & \begin{tabular}{|l} 
Transitional \\
surface slope
\end{tabular} & $\mathrm{H}$ & $7: 1$ & $7: 1$ & $7: 1$ & Army \\
\hline & & & $4: 1$ & $4: 1$ & $7: 1$ & Air Force \\
\hline & & & $4: 1$ & $4: 1$ & $\mathrm{~N} / \mathrm{A}$ & Navy and Marine Corps \\
\hline & & & \multicolumn{3}{|c|}{ See Remarks } & $\begin{array}{l}\text { See figures } 4-2,4-3.4-6 \\
4-9,4-10, \text { and } 4-11 \text { for } \\
\text { shape of the transitional } \\
\text { surface. }\end{array}$ \\
\hline & & & & & & $\begin{array}{l}\text { The transitional surface } \\
\text { starts at the lateral edges of } \\
\text { the primary surface and the } \\
\text { approach-departure } \\
\text { clearance surface. It } \\
\text { continues outward and } \\
\text { upward at the prescribed } \\
\text { slope to } 45.72 \mathrm{~m} \text { ( } 150 \mathrm{ft} \text { ) } \\
\text { above the established } \\
\text { airfield elevation. }\end{array}$ \\
\hline 13 & \begin{tabular}{|l|} 
Horizontal \\
surface radius
\end{tabular} & $\mathrm{E}$ & $\begin{array}{c}1,143 \mathrm{~m} \\
(3,750 \mathrm{ft}) \\
\text { for } 25: 1 \\
\text { approach- } \\
\text { departure } \\
\text { surfaces }\end{array}$ & N/A & N/A & $\begin{array}{l}\text { Navy and Marine Corps } \\
\text { airfields only. An imaginary } \\
\text { surface located } 45.72 \mathrm{~m} \\
\text { (150 ft) above the } \\
\text { established heliport } \\
\text { elevation, formed by } \\
\text { scribing an arc about the } \\
\text { end of each runway or } \\
\text { landing lane, and } \\
\text { interconnecting these arcs } \\
\text { with tangents }\end{array}$ \\
\hline
\end{tabular}


Table 24 (cont.). Rotary-wing imaginary surfaces for IFR approaches (UFC 3-260-01, Table 4-8).

\begin{tabular}{|c|c|c|c|c|c|c|}
\hline \multicolumn{7}{|c|}{ Rotary-Wing Imaginary Surfaces for IFR Approaches } \\
\hline No. & $\begin{array}{l}\text { Item } \\
\text { Description }\end{array}$ & $\begin{array}{l}\text { Legend } \\
\text { in } \\
\text { Figures }\end{array}$ & $\begin{array}{c}\text { Helicopter } \\
\text { Runway } \\
\text { and } \\
\text { Landing Lanes }\end{array}$ & Standard & $\begin{array}{l}\text { lelipad } \\
\text { Same Direction } \\
\text { Ingress/Egress }\end{array}$ & Remarks \\
\hline & & & $\begin{array}{c}1,554.48 \mathrm{~m} \\
(5,100 \mathrm{ft}) \text { for } \\
34: 1 \text { approach- } \\
\text { departure } \\
\text { surfaces }\end{array}$ & N/A & N/A & $\begin{array}{l}\text { Navy and Marine Corps } \\
\text { airfields only }\end{array}$ \\
\hline & & & N/A & $\begin{array}{l}1,402.08 \mathrm{~m} \\
(4,600 \mathrm{ft})\end{array}$ & $\begin{array}{l}1,402.08 \mathrm{~m} \\
(4,600 \mathrm{ft})\end{array}$ & $\begin{array}{l}\text { Navy and Marine Corps } \\
\text { airfields only. Circular in } \\
\text { shape, located } 45.72 \mathrm{~m} \\
\text { ( } 150 \mathrm{ft} \text { ) above the } \\
\text { established heliport or } \\
\text { helipad elevation, defined } \\
\text { by scribing an arc with a } \\
1,402.08 \mathrm{~m}(4,600 \mathrm{ft}) \\
\text { radius about the center } \\
\text { point of the helipad }\end{array}$ \\
\hline 14 & $\begin{array}{l}\text { Elevation of } \\
\text { horizontal } \\
\text { surface }\end{array}$ & $\mathrm{H}$ & $\begin{array}{l}45.72 \mathrm{~m} \\
(150 \mathrm{ft})\end{array}$ & $\begin{array}{l}45.72 \mathrm{~m} \\
(150 \mathrm{ft})\end{array}$ & $\begin{array}{l}45.72 \mathrm{~m} \\
(150 \mathrm{ft})\end{array}$ & $\begin{array}{l}\text { Navy and Marine Corps } \\
\text { airfields only }\end{array}$ \\
\hline
\end{tabular}

NOTES:

1. Metric units apply to new airfield construction and, where practical, modification to existing airfields and heliports, as discussed in paragraph 1-4.4

2. The criteria in this manual are based on aircraft specific requirements and are not direct conversions from inch-pound (English) dimensions. Inch-pound units are included only as a reference to the previous standard.

3. Airfield and heliport imaginary surfaces and safe wingtip clearance dimensions are shown as a direct conversion from inch-pound to SI units.

4. N/A = not applicable 


\section{Drop Zones}

The primary document for DZ criteria is AFI 13-217: Drop Zone and Landing Zone Operations.

\subsection{Responsibility}

DZ size and selection are the shared responsibility of the supporting-force commander and the supported force commander. The supported force is responsible for DZ establishment, operation, and safety and for eliminating or accepting ground hazards associated with the DZ. The use of standard DZ sizes depicted in Table 25 and Figure 18 are essential to safe operations. They are required for Air Force unilateral aircrew training and recommended for allied/joint training airdrops. The supported force will take responsibility for injury of personnel and damage to equipment that could result from using a DZ that does not meet the standard DZ size criteria.

- The airlift mission commander is normally responsible for airdrop accuracy and safety of flight for all aircrew-directed airdrops at DZs meeting the above size criteria.

- The supported force is normally responsible for airdrop accuracy when using Ground Marked Release System, Verbally Initiated Release System, or jumpmaster-directed release procedures.

- The jumpmaster is responsible for airdrop accuracy when using jumpmaster-directed release procedures. 
Table 25. Standard DZ size criteria (AFI 13-217, Table 2.1).

\begin{tabular}{|c|c|c|c|c|}
\hline $\begin{array}{l}\text { ALTITUDE } \\
\text { (AGL) }\end{array}$ & $\begin{array}{c}\text { WIDTH } \\
(\text { NOTE } 1,2,4)\end{array}$ & \multicolumn{3}{|c|}{ LENGTH (NOTE 3, 4) } \\
\hline \multicolumn{5}{|c|}{$\begin{array}{l}\text { C-130 Container Delivery System (CDS) / Container Release System (CRS) / Container Ramp } \\
\text { Loads (CRL) / Low Cost Aerial Delivery System - Low Velocity (LCADS-LV) }\end{array}$} \\
\hline \multirow{7}{*}{ To 600 feet } & \multirow{7}{*}{$400 \mathrm{yds} / 366 \mathrm{~m}$} & $\begin{array}{l}\begin{array}{l}\text { Single } \\
\text { containers }\end{array} \\
\end{array}$ & $\begin{array}{l}\text { Double } \\
\text { containers }\end{array}$ & \\
\hline & & 1 & $1-2$ & $400 \mathrm{yds} / 366 \mathrm{~m}$ \\
\hline & & 2 & $3-4$ & $450 \mathrm{yds} / 412 \mathrm{~m}$ \\
\hline & & 3 & $5-6$ & 500 yds $/ 457 \mathrm{~m}$ \\
\hline & & 4 & $7-8$ & 550 yds $/ 503 \mathrm{~m}$ \\
\hline & & $5-8$ & $9-16$ & $700 \mathrm{yds} / 640 \mathrm{~m}$ \\
\hline & & $9-12$ & $10-24$ & 850 yds $/ 777 \mathrm{~m}$ \\
\hline Above 600 feet & \multicolumn{4}{|c|}{$\begin{array}{l}\text { Add } 40 \mathrm{yds} / 36 \mathrm{~m} \text { to width and length for each } 100 \text { feet above } 600 \text { feet (add } 20 \mathrm{yds} / 18 \\
\mathrm{~m} \text { to each side of DZ, } 20 \mathrm{yds} / 18 \mathrm{~m} \text { to each end) }\end{array}$} \\
\hline \multicolumn{5}{|c|}{ CDS / LCADS-LV (C-17) } \\
\hline \multirow{7}{*}{ To 600 feet } & \multirow{7}{*}{$450 \mathrm{yds} / 412 \mathrm{~m}$} & $\begin{array}{l}\begin{array}{l}\text { Single } \\
\text { containers }\end{array} \\
\end{array}$ & $\begin{array}{l}\text { Double } \\
\text { containers }\end{array}$ & \\
\hline & & \begin{tabular}{|l|l}
1 & \\
\end{tabular} & $1-2$ & 590 yds $/ 540 \mathrm{~m}$ \\
\hline & & 2 & $3-4$ & $615 \mathrm{yds} / 562 \mathrm{~m}$ \\
\hline & & 3 & $5-6$ & $665 \mathrm{yds} / 608 \mathrm{~m}$ \\
\hline & & $4-8$ & $7-16$ & $765 \mathrm{yds} / 700 \mathrm{~m}$ \\
\hline & & $9-14$ & $17-28$ & $915 \mathrm{yds} / 837 \mathrm{~m}$ \\
\hline & & $15-20$ & $29-40$ & $1065 \mathrm{yds} / 974 \mathrm{~m}$ \\
\hline Above 600 feet & \multicolumn{4}{|c|}{$\begin{array}{l}\text { Add } 40 \mathrm{yds} / 36 \mathrm{~m} \text { to width and length for each } 100 \text { feet above } 600 \text { feet (add } 20 \mathrm{yds} / 18 \\
\mathrm{~m} \text { to each side of } \mathrm{DZ}, 20 \mathrm{yds} / 18 \mathrm{~m} \text { to each end) }\end{array}$} \\
\hline \multicolumn{5}{|c|}{ High Velocity (HV) CDS / HV-LCADS (using 12, 22, or 26 foot ring slot parachutes) } \\
\hline \multirow[b]{2}{*}{ To 3000 feet } & \multirow[b]{2}{*}{$580 \mathrm{yds} / 530 \mathrm{~m}$} & \multicolumn{3}{|c|}{$660 \mathrm{yds} / 604 \mathrm{~m}$} \\
\hline & & \multicolumn{3}{|c|}{$\begin{array}{l}\text { Add } 50 \mathrm{yds} / 46 \mathrm{~m} \text { to trailing edge for each additional row of } \\
\text { containers. }\end{array}$} \\
\hline $\begin{array}{l}\text { Above } 3000 \\
\text { feet }\end{array}$ & \multicolumn{4}{|c|}{$\begin{array}{l}\text { Add } 25 \mathrm{yds} / 23 \mathrm{~m} \text { to each side and } 100 \mathrm{yds} / 91 \mathrm{~m} \text { to each end for every } 1000 \text { feet } \\
\text { increase in drop altitude }\end{array}$} \\
\hline \multicolumn{5}{|c|}{ High Altitude Airdrop Resupply System (HAARS) CDS } \\
\hline \multirow{2}{*}{ To 3000 feet } & \multirow[t]{2}{*}{$500 \mathrm{yds} / 457 \mathrm{~m}$} & \multicolumn{2}{|c|}{$1-8$ containers } & $1200 \mathrm{yds} / 1098 \mathrm{~m}$ \\
\hline & & \multicolumn{2}{|c|}{9 or more containers } & $1900 \mathrm{yds} / 1739 \mathrm{~m}$ \\
\hline $\begin{array}{l}\text { Above } 3000 \\
\text { feet }\end{array}$ & \multicolumn{4}{|c|}{$\begin{array}{l}\text { Add } 25 \mathrm{yds} / 23 \mathrm{~m} \text { to each side and } 50 \mathrm{yds} / 46 \mathrm{~m} \text { to each end for every } 1000 \text { feet } \\
\text { increase in drop altitude }\end{array}$} \\
\hline \multicolumn{5}{|c|}{ High Speed Low Level Aerial Delivery System (HSLLADS) } \\
\hline & $\begin{array}{l}300 \mathrm{yds} / \\
274 \mathrm{~m}\end{array}$ & ds / 549 & & \\
\hline
\end{tabular}


Table 25 (cont.). Standard DZ size criteria (AFI 13-217, Table 2.1).

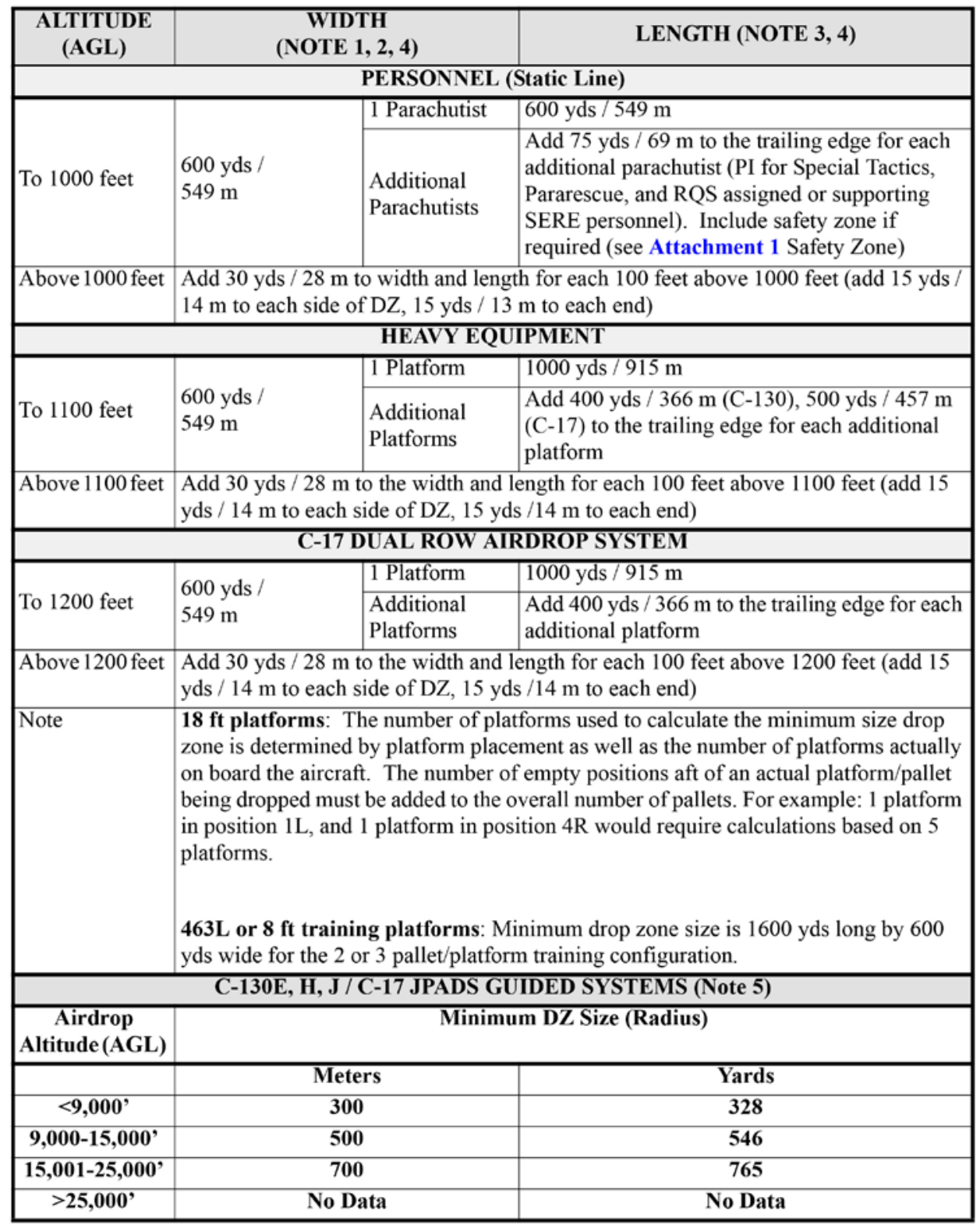


Table 25 (cont.). Standard DZ size criteria (AFI 13-217, Table 2.1).

\section{NOTES:}

1. C-130 DZ width adjustments (N/A for CSAR assigned/gained aircraft, or AFSOC assigned/ gained aircraft OPCON to USSOCOM or a theater special operations command):

a. Day visual formations; increase width by $100 \mathrm{yds} / 92 \mathrm{~m}$ ( $50 \mathrm{yds} / 46 \mathrm{~m}$ on each side)

b. Night visual single ship; increase width by $100 \mathrm{yds} / 92 \mathrm{~m}$ (50 yds / $46 \mathrm{~m}$ on each side)(N/A for C-130J GPS drops)

c. Night visual formation; increase width by $200 \mathrm{yds} / 184 \mathrm{~m}$ (100 yds / $92 \mathrm{~m}$ on each side)

d. SKE formation; increase width by $400 \mathrm{yds} / 366 \mathrm{~m}$ (200 yds / $184 \mathrm{~m}$ on each side)

2. C-17 DZ width adjustments (more than one may be required)

a. Day/Night visual formation, increase width by $100 \mathrm{yds} / 92 \mathrm{~m}$ ( $50 \mathrm{yds} / 46 \mathrm{~m}$ on each side)

b. Night pilot directed airdrops; increase width by $100 \mathrm{yds} / 92 \mathrm{~m}$ ( $50 \mathrm{yds} / 46 \mathrm{~m}$ on each) (N/A for C-17 GPS drops)

c. SKE formation (HE/CDS); increase width by $400 \mathrm{yds} / 366 \mathrm{~m}$ (200 yds / $183 \mathrm{~m}$ on each side)

d. Personnel formation, minimum DZ basic width using center PIs is 1240 yards for 2-ship elements and 1800 yds for 3-ship elements. When using offset PIs, minimum basic width is 1050 yds for 2-ship elements and 1300 yds for 3-ship elements. Drop altitude adjustments from chart still apply.

3. Length Adjustments (N/A for AFSOC assigned/gained, aircraft OPCON to USSOCOM, or a theater special operations command)

a. Night visual airdrops; increase length by $100 \mathrm{yds} / 92 \mathrm{~m}$ (50 yds / $46 \mathrm{~m}$ on each end)

4. I-CDS DZ length and width requirements will be IAW 2.5.2. and normal high-altitude CDS/HVCDS adjustments in Table 2.1 .

5. Normal training minimum JPADS DDZ size requirements

a. These minimum DZ size requirements are for normal JPADS training outside of Yuma Proving Grounds (YPG). DZ size requirements at YPG are at the discretion of AMC/A3D, NATICK and YPG as necessary for testing, development and evaluation of JPADS systems. JPADS upgrade training for aircrews may occur at YPG or DZ sizes smaller than stated above with the concurrence of $\mathrm{AMC} / \mathrm{A} 3 \mathrm{D}$.

b. During contingency use, recommended minimum JPADS DZ size is $200-300$ meters $(218-328$ yards) radius circular. Ultimately, minimum JPADS DZ size restsmwith the user and the Joint Force Commander (or Director of Mobility Forces if so delegated). 
Figure 18. Circular DZ computation (AFI 13-217, Fig. 2.1).

Option 1 (Surveyed)

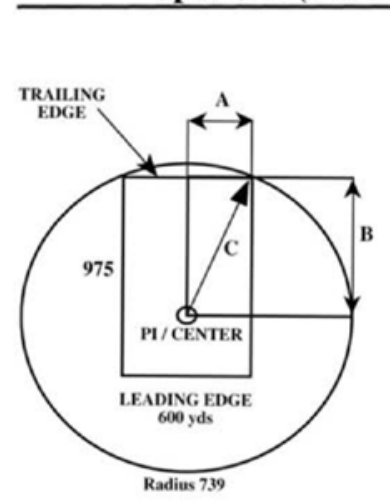

Point of Impact located at circlular DZ center. The radius of the circular DZ is the minimum distance between the Point of Impact and one of the trailing edge corners on a rectangular DZ.
Option 2 (Mission Specific)

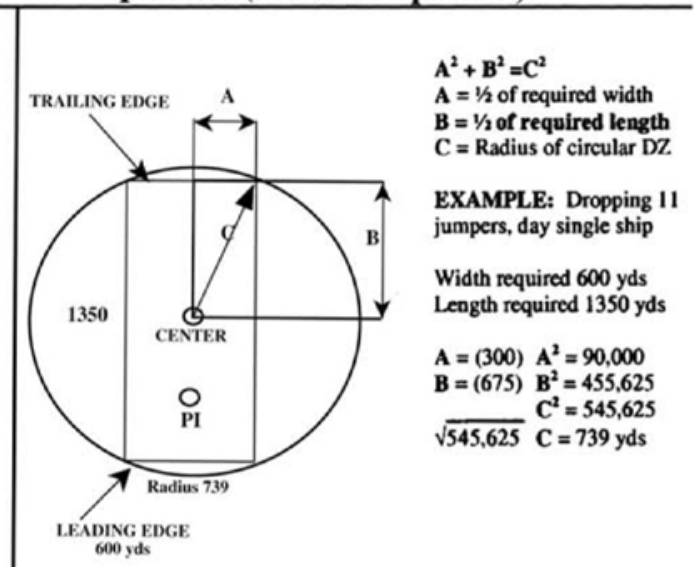

Point of Impact offset from circular DZ center. The radius of the circular DZ is the minimum distance between the Center of Mass and one of the trailing edge corners on a rectangular DZ.

\subsection{DZ surveys}

DZ surveys document the conditions that existed at the time of the survey. Recommended uses may be based on minimum requirements and should not be misconstrued to be all-inclusive (i.e., a DZ recommended for personnel may be suitable for a single parachutist but not for 15, or it may be suitable for a C-130 but not a C-17). It is the responsibility of the supporting force and supported forces involved to ensure that any DZ being considered for use meets the requirements for their specific operation.

During contingencies, when time or situation does not permit completion of a full DZ survey, a tactical DZ survey may be required to support highly mobile ground forces. The survey should obtain and forward for review as much information as practical.

When using a tactical DZ, the airlift unit assumes responsibility for aircraft safety of flight, and the receiving unit assumes responsibility for injury to personnel or damage to equipment or air items. The DZ size should be determined by the mode of delivery, load dispersal, and discussion with the receiving unit regarding air-item recoverability and load survivability. 


\subsection{Drop altitude}

During contingency and wartime operations, the supported forces commander, in conjunction with the supporting-forces commander, will determine the drop altitude for personnel and equipment drops.

\subsection{Drop airspeed}

Standard parachute airdrops are performed at the airspeed ranges indicated in mission design series specific aircraft AFI and AFI 11-231 (for computed air release point airdrops).

\subsection{Drop-zone criteria}

DZ selection should be based on enemy threats, mission requirements, aircraft and aircrew capabilities, parachutist capabilities, type of parachutes used, and type of equipment to be airdropped.

\subsubsection{Military free-fall DZs}

For military free-fall DZs (including operations using MC-4, MC-5, SOV$3 \mathrm{HH}$ or approved equivalent parachutes deployed in free fall or by static line) the jumpmaster will determine the minimum size DZ based on the number of personnel to be dropped, jumper proficiency, and the prevailing winds.

\subsubsection{Joint precision airdrop system / improved container delivery system (JPADS/I-CDS) DZs}

J PADS/ I-CDS refers to both GPS (Global Positioning System) guided systems and traditional ballistic airdrop loads using Precision Airdrop System Mission Planner (PADS-MP) for more precise computed release points. Ballistic airdrop loads used in conjunction with the PADS-MP are referred to as I-CDS.

\subsubsection{JPADS (Guided Systems) DZs}

JPADS DZs are typically circular. The point of impact (PI) for JPADS DZs is located at the DZ center point. PI placement should allow for a circular DZ of minimum size to be contained within the surveyed DZ boundaries in the event a circular DZ survey does not exist. SomeJ PADS multi-platform loads may drive elliptical DZs, approximated by rectangular surveyed 
boundaries. There is no rectangular AFI 13-217 minimum DZ size requirement for J PADS loads; however, a rectangular DZ may be used if the circular DZ requirements are met within the boundaries of the rectangular DZ.

During contingency operations, the supported force will determine the J PADS (guided systems) minimum DZ size under advisement of the supporting-force aircrew by using Table 25 Note 5.b. as a starting reference. During contingency operations, a J PADS DZ and Launch Acceptability Region should be located within a Restricted Operating Zone. J PADS DZs will be selected to guarantee that all bundles land within its confines to the maximum extent possible.

\subsubsection{I-CDS}

I-CDS DZs are typically normal rectangular CDS (container delivery system) or high-velocity CDS DZs in accordance with Table 25. During contingency operations, I-CDS minimum DZ size is at the discretion of the supported force and the joint force commander. The user will accept responsibility for damage to structures, persons, and equipment located on the surveyed DZ or the Table 25 minimum-sized DZ, whichever is greater, as a result of the airdrop.

\subsubsection{Area DZ}

An area DZ (Figure 19) consists of a start point (point A), an endpoint (point B), and a pre-arranged flight path (line of flight) over a series of acceptable drop sites between these points. The distance between points A and B generally should not exceed 15 nautical miles (n.m.), and changes in ground elevation within $0.5 \mathrm{n} . \mathrm{m}$. of the centerline should not exceed $300 \mathrm{ft}$. The reception committee may receive the drop at any location between point $A$ and point $B$ within $0.5 \mathrm{n} . \mathrm{m}$. of the centerline. Once the prebriefed signal or electronic NAVAID has been identified and located, the drop may occur. Area DZs are not applicable to C-17 operations except for Special Operations Low Level II qualified crews. 
Figure 19. Area drop zone (AFI 13-217, Fig. 2.2).

ACCEPTABLE DROP STTES

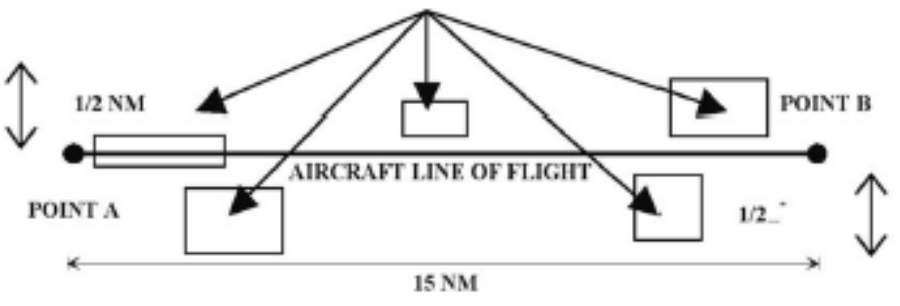

\subsubsection{Random points of impact (RPI)}

When mission requirements dictate, the RPI placement option may be used in one of two ways. Option One: The mission commander will notify the DZ controller at least 24 hours in advance that RPI placement will be used. When the standard DZ is established, the controller will randomly select a point on the DZ and establish that point as the PI for the airdrop. In this case, the controller will ensure that the DZ minimum size requirements for the load being dropped are met and that the entire DZ falls within the surveyed boundaries. Option Two: The mission commander or supported force commander may request the DZ be established with the PI at a specific point on the DZ. Requests should be made at least 24 hours in advance. The requester will ensure that the minimum standard DZ size criteria are met for the type of load being dropped and that the entire DZ falls within the surveyed boundaries.

\subsubsection{Multiple points of impact (MPI)}

MPI airdrops are authorized if all personnel involved have been properly briefed. MPI airdrops are defined as an aerial delivery method that allows for the calculated dispersal, both laterally and longitudinally, of airdropped loads to predetermined locations on a DZ. The DZ must meet the minimum size requirements for each PI, and the precise location of each PI must be provided to aircrews (see Table 25 and Table 26).

Offset PIs are computed from the surveyed center PI. When used, a $229 \mathrm{~m}$ (250 yd) left/right offset will be used for 3-ship operations; and a $115 \mathrm{~m}$ (125yd) left/right offset will be used for 2-ship operations. The DZ width must be increased accordingly to meet the distance criteria from the DZ edge to the PI. This manner of placement reduces the effects of wake turbulence across the DZ (see Table 26). C-17 formation personnel airdrop may require offset (laterally displaced) PIs (see Table 26). 
Table 26. Standard point of impact placement (AFI 13-217, Table 2.2).

\begin{tabular}{|c|c|c|}
\hline TYPE DROP & \multicolumn{2}{|c|}{ DISTANCE FROM APPROACH END } \\
\hline C-130 & DAY & NIGHT \\
\hline CDS & 200 yds / $183 \mathrm{~m}$ & 250 yds / $229 \mathrm{~m}$ \\
\hline Personnel & 300 yds / $274 \mathrm{~m}$ & 350 yds / $320 \mathrm{~m}$ \\
\hline Equipment & 500 yds / $457 \mathrm{~m}$ & 550 yds / $503 \mathrm{~m}$ \\
\hline C-17 & DAY / NIGHT / IMC & NIGHT Pilot Directed Airdrop (PDA) \\
\hline CDS / DRAS & 225 yds / $206 \mathrm{~m}$ & 275 yds / $251 \mathrm{~m}$ \\
\hline Personnel & 300 yds / $274 \mathrm{~m}$ & 350 yds / $320 \mathrm{~m}$ \\
\hline Equipment & 500 yds / 457 m & 550 yds / $503 \mathrm{~m}$ \\
\hline \multicolumn{3}{|c|}{$\begin{array}{l}\text { NOTES: } \\
\text { 1. For lateral placement, the PI must be located at least one-half the width of the mini- } \\
\text { mum size DZ (based upon type airdrop and airdrop formation) from the closest side of } \\
\text { the DZ. EXCEPTION: C-17 personnel drops may use an offset PI of } 125 \text { or } 250 \text { yds } \\
\text { left/right of planned PI, depending on formation size. } \\
\text { 2. The PI may be located anywhere within the surveyed DZ boundaries as long as the } \\
\text { minimum required DZ size for that type airdrop and airdrop formation fits within the } \\
\text { boundaries, and provided the distance from the leading edge and sides is complied } \\
\text { with. All participants must be briefed when using this option. } \\
\text { 3. JPADS guided systems PI will be the DZ centerpoint unless otherwise coordinated by } \\
\text { the supported forces commander as designated supported forces authority by respec- } \\
\text { tive Division Commander }\end{array}$} \\
\hline
\end{tabular}

\subsubsection{Tactical and special-purpose DZ}

Tactical DZs are used primarily during exercises or contingencies. They provide the supported forces commander with a means to respond rapidly to user requests through the rapid survey and approval process. Tactical DZs are normally restricted to missions supporting actual resupply and personnel infiltration airdrops (versus proficiency jumps, simulated airdrop training bundles, etc.). Tactical DZ surveys are done in an abbreviated manner but still require a physical survey of the DZ by special tactics combat controllers, the Air Mobility Liaison Officer, or the supported force to ensure DZ suitability. A safety-of-flight review is also required.

Special purpose DZs are only approved for use by Air Force special tactics, combat rescue officers, pararescue, and Rescue Squadron assigned or supporting survival, evasion, resistance, and escape specialists.

Shrub brush, thickets, small trees, and tundra areas are not considered hazardous to jumpers. Tree stumps that would be considered hazardous cannot be located closer than $50 \mathrm{~m}$ ( $55 \mathrm{yd}$ ) from the center of the target. 
The jump master must exercise risk management when conducting operational mission training and should perform an extensive evaluation prior to deployment.

\subsubsection{Open-field DZ}

Caution will be exercised when siting DZs with respect to terrain and obstacles such as runways, lights, high-tension lines, rocky terrain, etc., that could be hazardous to jumpers. Hazards must not be located within $100 \mathrm{~m}$ (110 yd) of the center of the DZ except when conducting runway assault operations and demonstration jumps.

\subsubsection{Tree-jump DZ}

The criteria for selecting open-field jumps also apply to tree-jump areas; in addition, they will be selected to be relatively free of stumps and dead falls. Certain trees have hazardous features, such as excessive height, sloping branches, or no branches, which should be taken into account when selecting the DZ. Complete tree-jump equipment will be worn when conducting intentional tree jumps.

\subsection{Aerial power-line restrictions}

Power lines present a significant hazard to jumpers. J umpers can sustain life threatening injuries from electric shock or falls from a collapsed canopy. To reduce this hazard, DZs should have no power lines located within $1000 \mathrm{~m}$ ( 0.6 miles) of any DZ boundary. AFI 13-217 (2007) provides additional suggestions for dealing with power lines that may not be applicable to contingency operations.

\subsection{Airdrop winds}

DZ wind information is critical to airdrop accuracy and is used by aircrews to compute the adjusted release point. It is imperative that accurate and timely wind data be transmitted to the aircrew. This includes not only surface wind and the computed mean effective wind but also any unusual observations (i.e., wind shear or local phenomena that could affect wind direction, speed, or restrictions to visibility).

The surface wind at the DZ is normally measured by using an anemometer or other calibrated wind-measuring device. Wind direction is reported in magnetic degrees and wind speed in knots. The direction reported is the 
direction the wind is coming from. Table 27 and Table 28 list surface-wind limitations. AFT 13-217 (2007) also discusses and defines mean effective wind.

Table 27. Surface-wind limits for CDS equipment airdrops (AFI 13-217, Table 2.3).

\begin{tabular}{|l|l|}
\hline \multicolumn{1}{|c|}{ TYPE CDS/EQUIPMENT DROP } & \multicolumn{1}{c|}{ SURFACE WIND LIMITS (KNOTS) } \\
\hline USAF Equipment & 17 \\
\hline $\begin{array}{l}\text { USAF CDS or LV-LCADS using G-12 } \\
\text { parachutes }\end{array}$ & 13 \\
\hline USAF CDS using G-13/14 parachutes & 20 \\
\hline $\begin{array}{l}\text { HAARS, HV CDS, HSLLADS, or } \\
\text { HV-LCADS }\end{array}$ & No Restriction \\
\hline $\begin{array}{l}\text { CDS/Equipment using Joint Precision } \\
\text { Airdrop System (JPADS) }\end{array}$ & $\begin{array}{l}\text { Refer to JPADS guidance system technical } \\
\text { manuals }\end{array}$ \\
\hline USAF Training Bundles (SATB) & 25 \\
\hline RAMZ/ARC/CRRC Bundles & $\begin{array}{l}25 \text { knots IAW FXC Technical Manual change 4 } \\
\text { dated Jun 2005 }\end{array}$ \\
\hline Non-USAF Equipment & Discretion of supported force DZSO \\
\hline
\end{tabular}

Table 28. Surface-wind limits for personnel airdrops (AFI 13-217, Table 2.4).

\begin{tabular}{|l|l|}
\hline TYPE PERSONNEL DROP (See NOTE) & \multicolumn{1}{|c|}{ SURFACE WIND LIMITS (KNOTS) } \\
\hline USAF Static Line Land / Intentional Tree & $13 / 17$ \\
\hline USAF Static Line Water & 25 \\
\hline USAF MFF Land / Intentional Tree & $18 / 22$ \\
\hline USAF MFF Water & 25 \\
\hline USAF Tandem & 18 \\
\hline Non-USAF Personnel & Discretion of unit DZSO \\
\hline $\begin{array}{l}\text { NOTE: During operational missions/contingencies, the airborne commander and/or team } \\
\text { leader will coordinate wind restrictions with the air mission commander/aircraft commander } \\
\text { based on operational requirements. }\end{array}$ \\
\hline
\end{tabular}




\section{Arctic Operations}

Criteria for Arctic and Antarctic operations fall into two categories: general operations and those that take place at the airfields supporting McMurdo Station, Antarctica.

The first is provided primarily by AFI 13-217 (2007), Chapter 4, which specifies guidance for contingency skiway operations of the LC-130. The Canadian civilian authority, Transport Canada, and the Canadian military have also produced two documents of relevance. The civilian document, dated 2011, is more up to date; but CFACM 10-100, Ice Strip Requirements for CC 130 Hercules, CC 115 Buffalo and CC 138 Twin Otter Operations, provides some basic information for operations in the Arctic. The following subsections present each of these documents separately.

The second category discusses the operations for wheeled aircraft at McMurdo Station, Antarctica. In this case, the runways are semi-permanent surface that are well maintained and reconstructed as needed. These runways have a long, site-specific history with dedicated construction and maintenance equipment and personnel. In Antarctica, operations depend on site observation and direct measurement, which includes a significant amount of drilling to determine ice thickness and temperature. The primary document for these criteria is FC 3-260-06F: Air Force Design, Construction, Maintenance, and Evaluation of Snow and Ice Airfield in Antarctica (2015).

Additionally, this chapter addresses a final separate consideration for ice and snow runways and skiways: roughness.

\subsection{LC-130 skiway and ski landing area criteria (AFI 13-217)}

\subsubsection{General}

Currently, the siting responsibility for skiway and ski landing areas rests with the Ski Landing Area Control Officer (SLACO) and the 109th Airlift Wing, Air National Guard. The 109th Airlift Wing develops and maintains procedures to train and certify SLACOs. SLACOs will be designated before the deployment of personnel and aircraft and will be either experienced LC-130 pilot or combat controllers experienced in LC-130 ski operations. 
The SLACO will be at the site and will examine the results of the Ski Landing Area testing, preparation, and marking. If the area meets requirements, the SLACO will, with the concurrence of the Camp Manager, advise the 109 Airlift Wing deployed commander that LC-130 ski landings and takeoffs may commence. A certified SLACO will remain at the Ski Landing Area during all initial LC-130 ski operations or until relieved by the deployed commander.

Agencies planning scientific research or military exercises must choose be tween construction of a Skiway or Ski Landing Area. Proposed landing locations must be submitted to 109 Airlift Wing/ 139 Airlift Squadron Tactics (DOW), 1 Air National Guard Road, Scotia, NY, so locations can be evaluated in terms of distance from hard-surface staging bases, cargo requirements, meteorological conditions, number of landings and takeoffs, duration of the operation, and the amount of cargo to be offloaded/ onloaded.

Agencies requiring landings and takeoffs on sea ice must also provide information on ice depth and surface characteristics. Table 29 reviews minimum thicknesses.

Table 29. Ice weight-bearing capacity (AFI 13-217, Table 4.1).

\begin{tabular}{|c|c|}
\hline SURFACE TEMPERATURE & MINIMUM ICE THICKNESS \\
\hline$-10 \operatorname{deg} C$ or less & 55 inches \\
\hline-10 to $-5 \operatorname{deg} C$ & 60 inches \\
\hline-5 to $0 \operatorname{deg} C$ & 85 inches \\
\hline
\end{tabular}

\subsubsection{Sea-ice depth testing and evaluation criteria}

Several agencies have done extensive research and testing of ice characteristics, and a large body of scientific research and testing data is available to agencies interested in ice-field or sea-ice operations. The following sections provide simple LC-130 ski operations limitations and procedures.

\subsubsection{Load-bearing capacity}

The load-bearing capacity of ice sheets varies with thickness, surface temperature, and weight of the aircraft and parking time. Minimum ice thickness required for LC-130 operations is based on data derived from U.S. Naval Civil Engineering Lab Technical Report R860, Study of Related Properties of Floating Sea-Ice Sheets and Summary of Elastic and ViscoElastic Analyses (Vaudrey 1977), and LC-130 aircraft field experience. The limits in Table 29 are established as minimum values for LC-130 aircraft. 
They may be applied up to the maximum ski landing and takeoff gross weight of 147,000 lb. Operations with ambient temperature above freezing must be evaluated and approved by the commander.

\subsubsection{Ice depth}

Testing sea-ice depth at landing and takeoff areas should include drilling through the ice at $500 \mathrm{ft}$ (152 m) intervals on alternated sides for the entire length of the landing area. Minimum depth values may not include surface snow or slush. Additional drill tests should be performed weekly during continuous operations or prior to resuming landings/ takeoffs after a period of nonuse of more than 1 week. The area should be checked regularly for signs of cracking or surface deterioration.

\subsubsection{Ice surface}

Surface evaluation of potential landing and takeoff areas is necessary to ensure the area is suitable for LC-130 ski operations. The better the natural conditions, the less preparation work will be necessary. The best condition is a relatively smooth ice surface with 2 or more years of snow accumulation to a depth of $12 \mathrm{in}$. $(30 \mathrm{~cm})$ (minimum acceptable depth is 6 in. [15 cm]). The following are conditions to avoid:

- An undulating or irregular ice subsurface can impact the skis during landing or takeoff. The undulating subsurface may be covered with snow that would be deformed by the skis during ski runs.

- Bare ice with little or no snow cover can create issues as snow cover is required to cushion and distribute loads over the skis. Even small irregularities or cracks in bare ice can create stress points along the ski that can cause damage.

- Large irregularities in the snow surface (sastrugis, ridges, and humps) require extensive surface preparation before ski operations.

Figure 20 (originally in AFI 13-217) shows the general configuration of a skiway with an adjacent cargo area. 
Figure 20. Skiway and cargo offload/onload area (AFI 13-217, Fig. 4.2).

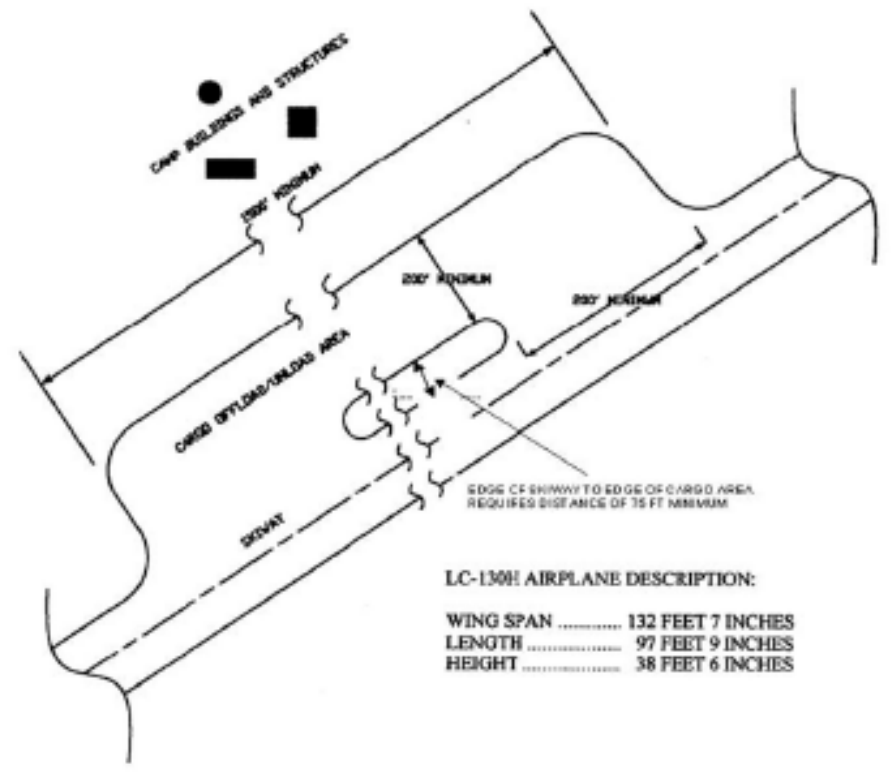

\subsubsection{Glacial and sea-ice ski landing areas}

Ice irregularities, often hidden by snow cover, can do significant damage to skis when struck at any speed. An ice crack with an edge of more than 4 in. may do damage at taxi speeds as the ski bridges the crack and a stress point is applied to the ski. Surface preparation must include a thorough survey of the landing area to look for ice irregularities and to study snow depths and characteristics. Any unacceptable irregularities must be removed. If the resulting surface is acceptable, ski operations can begin after appropriate marking and certification. Snow irregularities may be large enough to require the entire surface to be dragged or graded to fill low areas and to remove high areas. All undulating surfaces must be graded to minimize the slope and to prevent ski damage. Care must be taken not to remove the entire snow surface down to bare ice because snow cushions and distributes loads during ski takeoffs and landings (AFI 13-217 2007).

\subsection{Transport Canada AC 301-003}

\subsubsection{Floating ice thickness}

AC 301-003, Ice Aerodrome Development-Guidelines and Recommended Practices (Transport Canada 2011), is a civil aviation document but provides a relevant section of floating ice thickness with several nomographs. 
Figure 21 provides guidelines for the safe operation of aircraft under limited operating conditions with regard to minimum ice thickness. This data is recommended for use at ice aerodromes (both freshwater and sea ice) and relate primarily to determining the safe load-bearing capacity for runways by taking into account such factors as

- ice thickness,

- ice condition,

- ice types, and

- air temperatures.

\subsubsection{Limited movements}

Subject to the restrictions and adjustments outlined in the next sections, the minimum effective thickness of ice recommended for limited aircraft movements is given in Figure 21. The use of Figure 21 requires a value for ice flexural stress, and that appropriate value may be selected from Figure 22. Allowable flexural stress values selected from Figure 22 are generally conservative, and actual measurements of ice strength conducted by an ice specialist may permit operations on thinner ice covers or by heavier aircraft.

Limited aircraft movements may involve up to three landings per day. Landing on the recommended minimum ice thickness involves the risk of breakthrough if a detailed ice survey has not been carried out. Taking the following precautions will minimize this risk:

- Where practical, remove the aircraft from the ice as soon as possible.

- If ice conditions are uncertain, move the aircraft to another position if possible.

Inspect the ice at least once a day, and closely monitor any deflection or cracking of the ice; if cracking continues, reduce loads or cease the use of the runway if deemed necessary. 
Figure 21. Minimum ice thickness for limited aircraft movement. (Reproduced from Transport Canada AC 301-003, Appendix A*.)

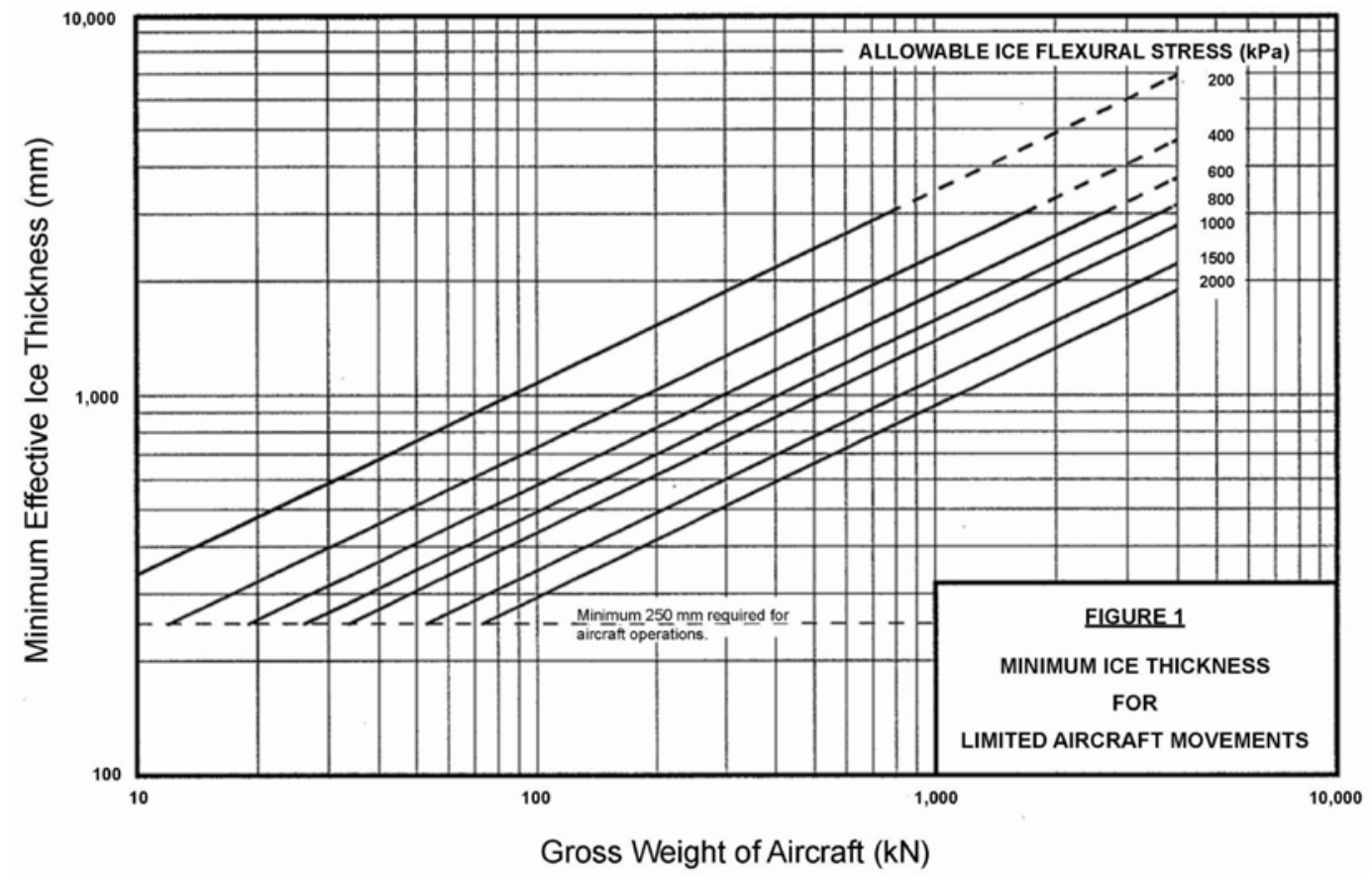

Figure 22. Recommended allowable ice flexural stress. (Reproduced from Transport Canada AC 301-003, Appendix B.)

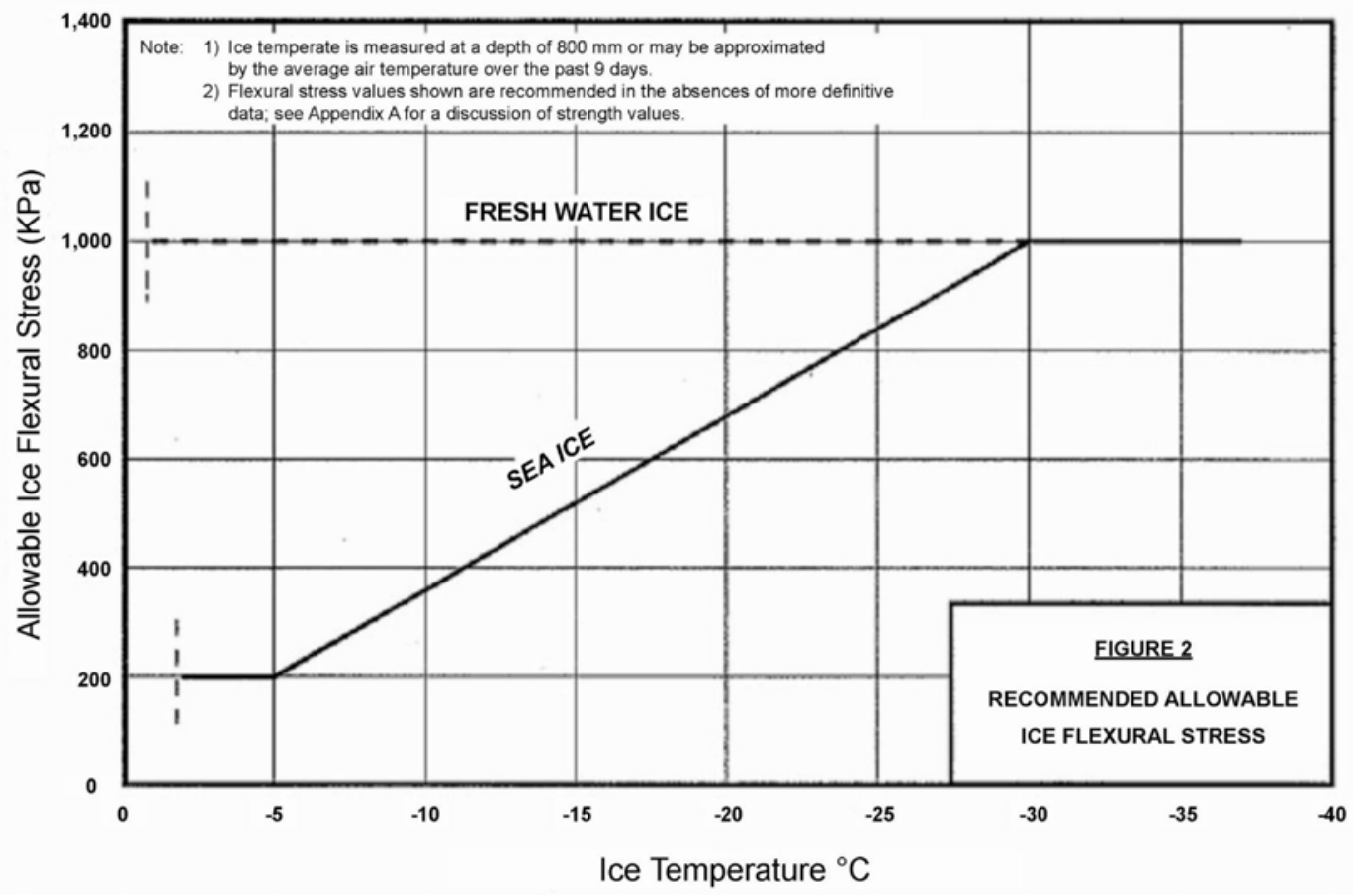

* The current ERDC/CRREL report was not produced in affiliation with or with the endorsement of Transport Canada. 


\subsubsection{Unlimited movements}

A qualified ice specialist should make an engineering analysis, including a detailed survey and investigation of the ice cover, to approve a runway for an unlimited number of landings per day.

The bearing capacity of an ice sheet can be affected more by ice quality than by ice thickness. Experienced ice specialists can make safe estimates of strength values through observations of the type and quality of the ice, which may be supplemented by measurements of ice strength. These estimates can provide the basis for a decision to allow unlimited aircraft movements or to allow loads in excess of the maximum recommended for limited use.

\subsubsection{Parking}

Aircraft may normally be parked on the minimum ice thickness given in Figure 21 provided that the maximum deflection of the ice sheet under the parked aircraft does not exceed $8 \%$ of the effective ice thickness.

When parking on ice of minimum thickness, an aircraft should be separated by a distance of at least one load influence radius from other loads, open cracks, or free ice edges. The load influence radius of an ice cover is a function of ice thickness, as given in Figure 23. The recommended minimum ice thickness should be increased by one-third for the parking of two aircraft with a separation of less than one load influence radius.

Parking is not recommended under any of the following conditions:

- If radial or circular cracks form around the loaded area or if continuous cracking is heard

- If deflection continues at an increasing rate

- If deflection exceeds $8 \%$ of the effective ice thickness

- If water appears on the surface of the ice cover 
Figure 23. Load influence radius of ice covers. (Reproduced from Transport Canada AC 301-003, Appendix C.)

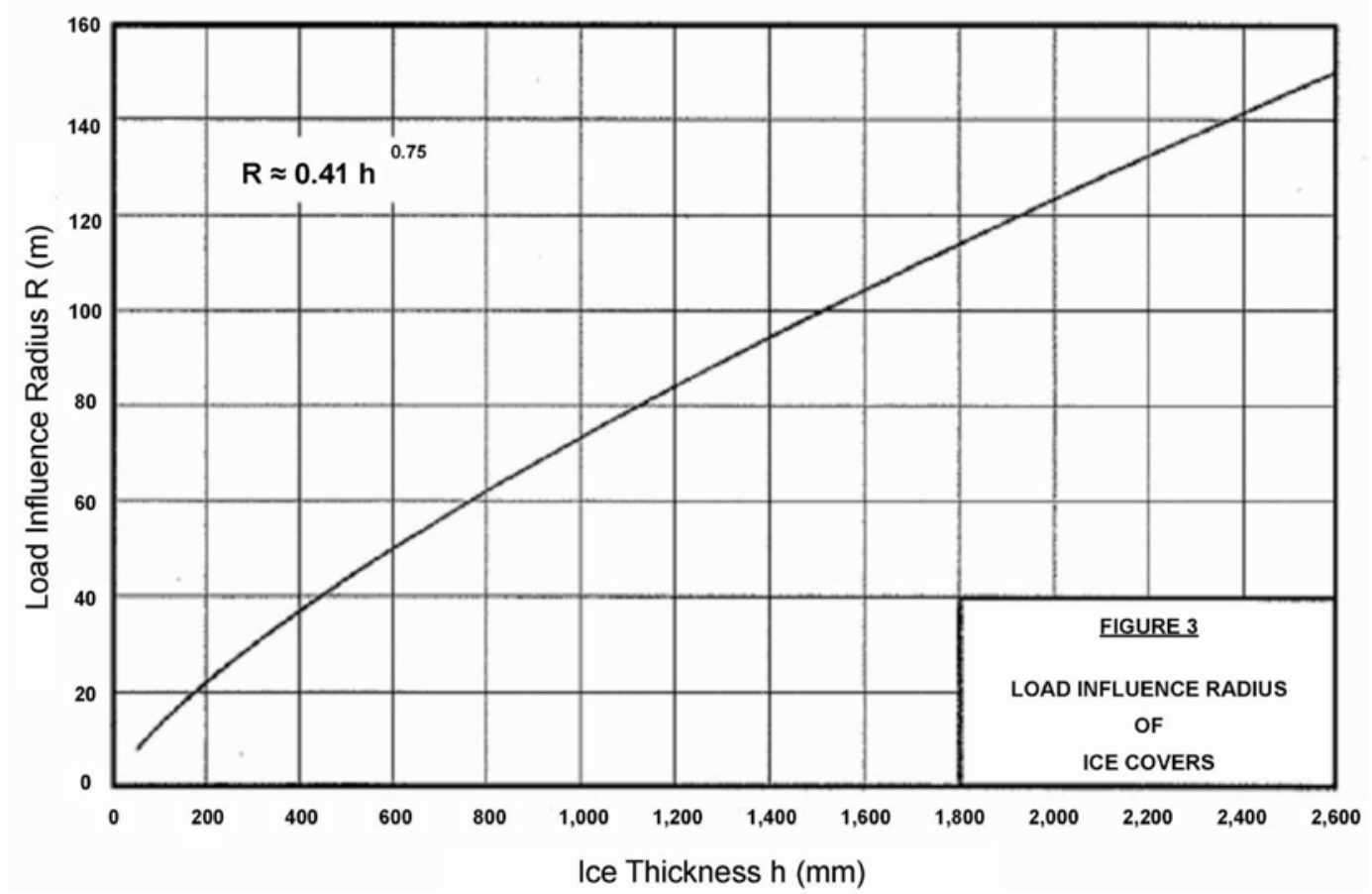

\subsubsection{Operations at thawing temperatures}

Recommended minimum ice thickness for limited aircraft operations must be adjusted if operations are to proceed with a daily average temperature higher than $-1^{\circ} \mathrm{C}$ for freshwater ice or higher than $-2^{\circ} \mathrm{C}$ for sea ice. Minimum required ice thickness should be increased by $5 \%$ or aircraft weight should be decreased by $10 \%$ for each consecutive day of elevated temperature. Operations should be suspended after four days of elevated temperatures or if the maximum air temperature exceeds $4^{\circ} \mathrm{C}$. Operations may have to be suspended before the fourth day if the condition of the ice surface deteriorates. Puddles of water should be filled with snow.

\subsubsection{Cracks}

Ice covers usually have many cracks caused by thermal contractions or by movements of the ice cover. Various types of cracks affect the bearing capacity of ice covers to varying degrees. Hairline cracks are lines in the ice not more than $2 \mathrm{~mm}$ (0.08 in.) in width. Wider cracks are classified as "wet" or "dry," depending on whether water can be observed. Wet cracks may refreeze to strengths equal to the original ice sheet, but the depth of healing should be verified. 
The adjustments in Table 30 should be made to allowable aircraft weight, or to minimum ice thickness, if cracks are present.

Table 30. Adjustments for cracked ice. (Reproduced from Transport Canada AC 301-003.)

\begin{tabular}{|c|c|c|}
\hline \multirow{2}{*}{ Type of Crack } & \multicolumn{2}{|c|}{ Adjustment to Either } \\
\cline { 2 - 3 } Hairline Cracks & Aircraft Weight & Ice Thickness \\
& None & None \\
Re-frozen Cracks & None & None \\
Dry Cracks ( $\leq 2 \mathrm{~cm}$ wide) \\
$\begin{array}{c}\text { Non-intersecting } \\
\text { Intersecting }\end{array}$ & Use $2 / 3$ weight \\
Use $1 / 3$ weight & Increase by $20 \%$ \\
Wet Cracks & & Increase by $70 \%$ \\
Non-intersecting & & \\
Intersecting & Use $1 / 2$ weight & Increase by $40 \%$ \\
& Use $1 / 4$ weight & Increase by $100 \%$ \\
\hline
\end{tabular}

Aircraft should cross single cracks at right angles and should not traverse areas where several active cracks intersect. Operations should be separated from an open or active lead by at least one load radius.

\subsubsection{Effective ice thickness}

Effective ice thickness is the thickness of good-quality dense ice. Dense freshwater ice may be taken as ice having a specific gravity of at least 0.90 . If the ice is layered and if one of the layers is of poor quality (e.g., light, drained snow ice, drained frazil ice, snow, or frazil slush), only the thicker section of continuous dense ice should be counted as effective ice thickness.

If a water layer is present within the ice cover, effective thickness corresponds to the thickness of the upper layer of ice. An exception may occur if the water layer is thin and not continuous or if the lower layer has sufficient thickness and strength to fully support the load at the temperature of $-1^{\circ} \mathrm{C}$ for freshwater ice, or $-2^{\circ} \mathrm{C}$ for sea ice.

The effective thickness of an ice cover can vary within wide limits. Dangerously thin areas can occur in the covers of rivers and estuaries and on lakes near the inlet or outlet of rivers. Thickness should be determined by holes spaced at not more than $15 \mathrm{~m}$ for a river, $30 \mathrm{~m}$ for a lake, and $90 \mathrm{~m}$ for smooth sea ice. Ice thickness should be checked once a week for average 
daily air temperatures between $-12^{\circ} \mathrm{C}$ and $-5^{\circ} \mathrm{C}$. Checks can be less frequent if effective ice thickness exceeds minimum requirements.

When a buildup of ice thickness is necessary, care must be taken to ensure that the built-up ice is of good quality. Snow cover should be removed prior to flooding. Alternately, if the snow cover is uniform, good-quality ice can be constructed by slow, careful flooding of the snow cover from the bottom upward. Flooding should occur outward from the runway centerline and should be limited to a depth that will freeze within 12 hours. A water depth of $50 \mathrm{~mm}$ will freeze overnight with an average air temperature of $-18^{\circ} \mathrm{C}$, and a depth of $90 \mathrm{~mm}$ will freeze overnight at $-30^{\circ} \mathrm{C}$. Ensure complete freezing before adding subsequent lifts.

\subsubsection{Resonance}

Under certain conditions, a taxiing aircraft will induce resonance waves under an ice cover, which can place considerable stress on the ice. When operating on ice that is at or close to recommended minimum thickness, observing the following precautions can increase safety and avoid resonance:

- Avoid taxiing at the speeds indicated in Figure 24.

- Avoid taxiing parallel to a shoreline at a distance of one load influence radius or less.

- Cross the shoreline at an angle of about $45^{\circ}$ when taxiing between an ice runway and [the] land [mass].

- Locate maneuvering surfaces on an ice runway more than two influence radii or less than one-half an influence radius from the shore. If this positioning is not practical, then the runway should be oriented at an angle of approximately $45^{\circ}$ to the shore. 
Figure 24. Critical taxiing speeds. (Reproduced from Transport Canada AC 301-003, Appendix D.)

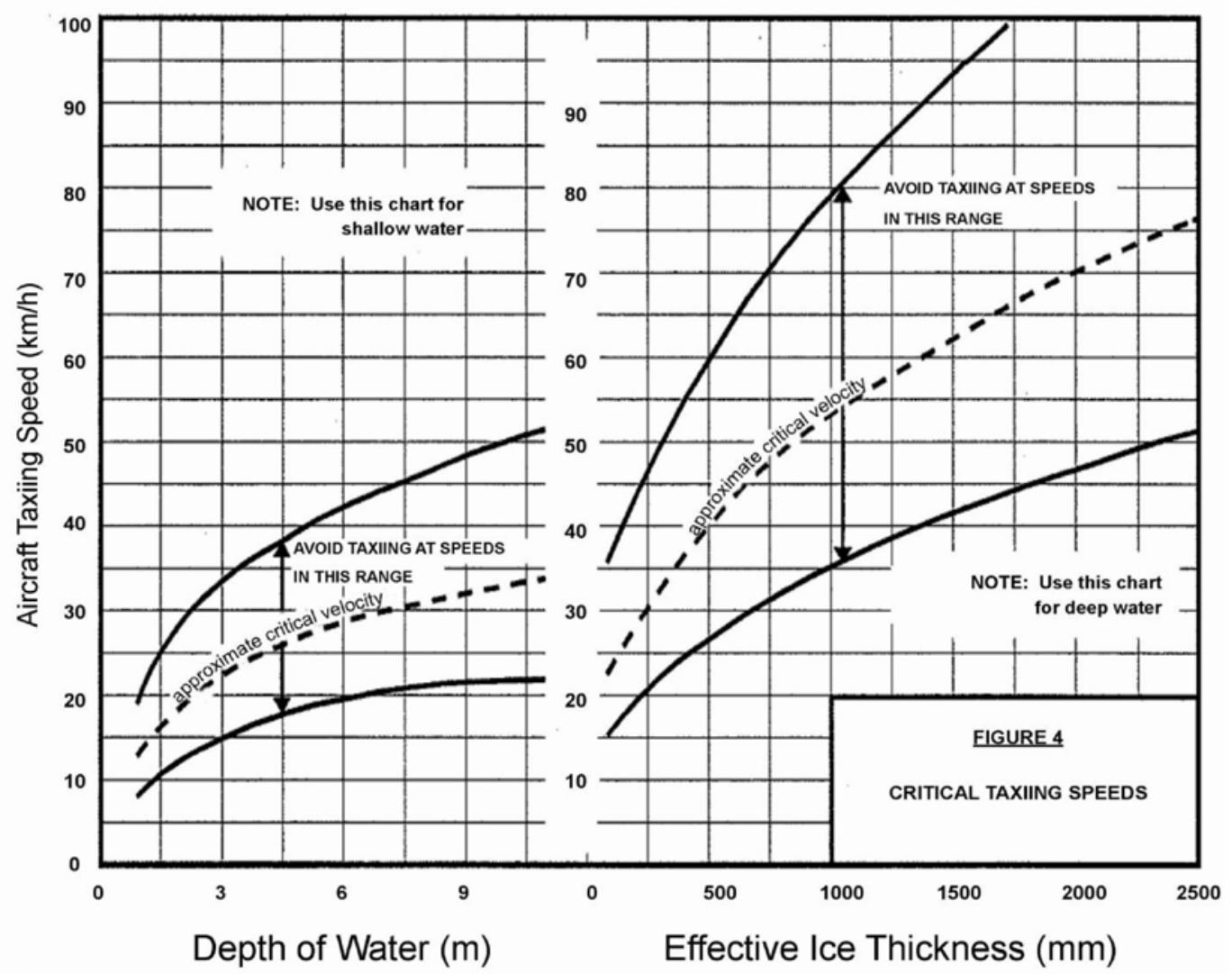

\subsubsection{Additional best practices}

- For conducting planning, development, and operational activities, AC 301-003 provides the following information for dealing with various other issues:

- The thickness of an ice cover should be determined with sufficient accuracy to establish a recommended maximum load. The runway should be closely inspected for ridges and depressions, which can be corrected by bulldozing and flooding, respectively.

- In addition to the inspection frequencies previously recommended, a runway used for the first time should be inspected after the first landing and after subsequent landings of heavier aircraft.

- An aircraft may land on ice without incident but may produce many cracks in the ice cover. The aircraft may then break through the ice 
when moving at a low speed during a subsequent take-off. Crack inspection should be a serious undertaking for ice aerodrome operators.

- Wheeled aircraft should not land on uncompacted snow deeper than one-third of the wheel diameter or in accordance with the Aircraft Operations Manual.

- Snow should be removed except for a 50 to $75 \mathrm{~mm}$ layer. Greater ice thickness is required when the ice is covered with deep snow and when the ice is used less than two days after the removal of deep snow. Snow banks should not be allowed at the ends of runways. The height of snow banks at the sides of runways should not exceed one-half of the ice thickness.

- The weight of stored materials, stationary loads, and snow should not exceed the aircraft loading allowed for the condition and thickness of the ice cover.

- Allowable weight for aircraft on skis is determined in the same manner as for wheeled aircraft.

\subsection{CFACM 10-100}

This manual plainly states, "CFACM 10-100 summarizes the best information currently available on the subject and presents data drawn principally from studies provided by the Ministry of Transport [now Transport Canada] and the United State Army's Cold Region Research and Engineering Laborator[y] (CRREL)." Since the 1982 publication of CFACM 10-100, Transport Canada has updated the graphs it references. There is no indication that CFACM 10-100 has been superseded by a new document.

This summary will not repeat the information from CFACM 10-100 that has been updated in AC 301-003 but will include some of the other basic information from CFACM 10-100 that may be of interest. Again, CFACM 10-100 specifically applies to CC-130 Hercules, CC-115 Buffalo, and CC138 Twin Otter operations. 


\subsubsection{Thickness requirement modifiers}

CFACM 10-100 discusses modifications to the required ice thickness based on ice type, temperature variations, wheeled versus ski-equipped aircraft, cracking, and loading frequency.

For ski-equipment aircraft, the following equation is given to determine the increase in allowable load as compared to wheeled aircraft:

$$
\text { Allowable Increase in Gross Weight }=\frac{\text { Length of Ski }}{\text { Seperation of Main Skis }} \times \frac{1}{3}
$$

For example, a Twin Otter Aircraft with a ski length of 76 in. and ski separation of $150 \mathrm{in}$. would have an allowable increase in gross weight of

$$
\frac{76}{150} \times \frac{1}{3}=\frac{1}{6}
$$

\subsubsection{Miscellaneous points}

Lakes: As a general rule, the ice on freshwater lakes is smoother on the surface than is the ice on bodies of salt water. Freshwater ice, however, should never be used after it has begun to candle, or separate into vertical needles. The restraints with regard to distance and orientation of air strips with respect to shore as noted in AC 301-003 must be observed. When only the minimum thickness of ice is available, the width of the lake should never be less than four times the corresponding load influence radius. On a freshwater lake where the ice is $30 \mathrm{in} .(76 \mathrm{~cm})$ thick, the bay should not be closer that two times the load influence radius, or in this situation, $400 \mathrm{ft}$, to the shore at any point to avoid complex resonance wave effects. Narrow bodies of water, whether lakes or rivers, are thus unsuitable for landing unless the ice is extremely thick, or unless an emergency exists.

Sea ice: The best location for a landing strip on sea ice is in a bay or behind a point, where the ice is not subject to the horizontal pressure from ice flows or the wave and swell effects of the open sea. Unprotected airfields can be carried away by changes of current or wind. The use of shelf ice for landing is also often practical. Active cracks, caused by the movement of ice in the vertical and horizontal direction, should be avoided. Such cracks often separate the bay ice from ice cover in the open sea. Pack 
ice in the open Artic is sometimes suitable for airfield purposes also. The usual factor limiting runway length on pack ice is, however, the distance between pressure ridges.

Slush hazard: Sometime deep snow cover is penetrated by water. Avoid landing in slush.

Emergency operations: CFACM 10-100 includes under the heading of "emergency operations" a method for estimating the thickness of ice based on the approximate date of freeze-up and the range of subsequent prevailing temperatures. This method, developed by the Snow, Ice, and Permafrost Research Establishment (SIPRE), CRREL's predecessor, may no longer be valid with current modeling techniques and therefore is not included here.

\subsection{Wheeled aircraft snow or ice runways (Antarctica)}

FC 3-260-06F provides guidance based on operations at McMurdo Station, Antarctica. The applicability to contingency operation LZs may be limited, but this review provides some specifics from FC 3-260-06F for completeness. FC 3-260-06F considers three potential surface conditions:

- Wheeled aircraft operations on glacial ice

- Wheeled aircraft operations on white ice (glacial ice capped with processed snow)

- Wheeled aircraft operations on sea ice

\subsubsection{Geometry}

Table 31 provides dimensional criteria for the layout and design of snow and ice runways. Minimum runway length shall be $3050 \mathrm{~m}$ (10,000 ft) for fully loaded C-17 aircraft operations and $2440 \mathrm{~m}$ (8000 ft) for fully loaded C-130 aircraft unless otherwise directed by the major command director of operations. Figure 25 shows the geometric criteria for a unidirectional runway and also provides the dimensional criteria for shoulders, taxiways, and overruns. 
Table 31. Runway dimensional requirements for C-130, LC130, and C-17 operations (FC 3-260-06F, Table 2-1).

\begin{tabular}{|c|c|c|c|}
\hline $\begin{array}{l}\text { Item } \\
\text { No. }\end{array}$ & Description & Requirement & Remarks \\
\hline 1 & Length (minimum) & See Remarks & $\begin{array}{l}\text { Minimum runway length will be } \\
\text { determined by the MAJCOM/A } 3 \text { for the } \\
\text { most critical aircraft in support of the } \\
\text { mission. }\end{array}$ \\
\hline 2 & Width & $46 \mathrm{~m}(150 \mathrm{ft})$ & $\begin{array}{l}\text { Since snow and ice runways are devoid } \\
\text { of traditional painted surface markings, } \\
\text { the runway will appear to be } 64 \mathrm{~m}(210 \\
\mathrm{ft}) \text { wide - the distance between the inner } \\
\text { marker flags. }\end{array}$ \\
\hline 3 & $\begin{array}{l}\text { Width of } \\
\text { shoulders } \\
\text { (minimum) }\end{array}$ & $7.6 \mathrm{~m}(25 \mathrm{ft})$ & $\begin{array}{l}\text { Remove all snow berms and snow drifts } \\
\text { in shoulder areas. All glacial ice, white } \\
\text { ice, compacted snow and sea ice in } \\
\text { shoulders shall be prepared to required } \\
\text { runway strength standards. }\end{array}$ \\
\hline 4 & $\begin{array}{l}\text { Longitudinal } \\
\text { grade }\end{array}$ & $\begin{array}{l}2 \% \text { maximum } \\
\text { (up or down) }\end{array}$ & $\begin{array}{l}\text { The maximum grade of any tangent, as } \\
\text { well as the total elevation change from } \\
\text { one threshold of the runway to the other, } \\
\text { shall not exceed } 2 \% \text {. }\end{array}$ \\
\hline 5 & $\begin{array}{l}\text { Longitudinal } \\
\text { grade change }\end{array}$ & $\begin{array}{l}\text { No grade } \\
\text { change greater } \\
\text { than } 0.5 \% \text { is to } \\
\text { occur within } 300 \\
\mathrm{~m}(1000 \mathrm{ft}) \text { from } \\
\text { the runway end }\end{array}$ & $\begin{array}{l}\text { Hold to minimum practicable. Grades } \\
\text { may be both positive and negative but } \\
\text { must not exceed the limit specified. } \\
\text { Applies to runway and shoulders. }\end{array}$ \\
\hline 6 & $\begin{array}{l}\text { Rate of } \\
\text { longitudinal } \\
\text { grade change }\end{array}$ & $\begin{array}{l}\text { Maximum } \\
0.167 \% \text { per } 30.5 \\
\mathrm{~m}(100 \mathrm{ft})\end{array}$ & $\begin{array}{l}\text { Grade changes will be held to a } \\
\text { minimum and will be gradual. Application } \\
\text { of this criterion will produce a vertical } \\
\text { curve having a } 182.9 \mathrm{~m} \text { ( } 600 \mathrm{ft} \text { ) length } \\
\text { for each percent of algebraic difference } \\
\text { between the two grades. Minimum } \\
\text { distance between grade changes is } 61 \\
\mathrm{~m} \text { ( } 200 \mathrm{ft}) \text {. Grade changes cannot } \\
\text { exceed } 1.5 \% \text { measured at } 61 \text {-m ( } 200 \text {-ft) } \\
\text { intervals. Applies to runway and } \\
\text { shoulders. } \\
\text { Note: In addition to these grade } \\
\text { requirements, the runway shall be } \\
\text { checked for high-frequency, low- } \\
\text { amplitude undulations that degrade } \\
\text { rideability and may decrease aircraft } \\
\text { stopping performance. Any dips, rises or } \\
\text { "chatter" shall be noted and corrected by } \\
\text { fine-grading and re-compacting the } \\
\text { surface. }\end{array}$ \\
\hline 7 & $\begin{array}{l}\text { Transverse slope } \\
\text { of runway }\end{array}$ & $1.5 \%$ maximum & $\begin{array}{l}\text { Transverse slopes can be flat and } \\
\text { uniform, or crowned at the centerline. A } \\
\text { crowned centerline is preferred. Sea ice } \\
\text { runway is flat. }\end{array}$ \\
\hline 8 & $\begin{array}{l}\text { Transverse slope } \\
\text { of shoulders }\end{array}$ & $\begin{array}{l}2 \% \text { max. down } \\
1 \% \text { max. up }\end{array}$ & $\begin{array}{l}\text { For a glacial ice surface, shoulders shall } \\
\text { slope down from the runway edge. A } \\
\text { white ice surface may slope down at } 2 \% \\
\text { maximum or up at } 1 \% \text { maximum. Sea } \\
\text { ice shoulders are flat. }\end{array}$ \\
\hline 9 & $\begin{array}{l}\text { Width of graded } \\
\text { area }\end{array}$ & $\begin{array}{l}\text { Minimum } 12.2 \mathrm{~m} \\
(40 \mathrm{ft})\end{array}$ & $\begin{array}{l}\text { The graded area is measured from the } \\
\text { outside edge of the shoulder. Graded } \\
\text { area will routinely have no more than } 25 \\
\text { mm ( } 1 \text { in) of loose snow cover. (During } \\
\text { clean-up following a drifting event, snow } \\
\text { up to } 300 \mathrm{~mm} \text { [12 in] may exist } \\
\text { immediately adjacent to runway markers } \\
\text { while the runway proper and the } \\
\text { shoulders are being maintained to the } 25 \\
\text { mm ( } 1 \text { in) standard in order to resume } \\
\text { critical flight operations. As soon as } \\
\text { practicable, any drift snow in the graded } \\
\text { area must be removed to maintain the } \\
\text { overall runway standard.) }\end{array}$ \\
\hline
\end{tabular}


Table 31 (cont.). Runway dimensional requirements for C-130, LC-130, and C-17 operations(FC 3-260-06F, Table 2-1).

\begin{tabular}{|c|c|c|c|}
\hline $\begin{array}{l}\text { Item } \\
\text { No. }\end{array}$ & Description & Requirement & Remarks \\
\hline 10 & $\begin{array}{l}\text { Transverse slope } \\
\text { of graded area }\end{array}$ & $\begin{array}{l}2 \% \text { maximum } \\
\text { (up or down) }\end{array}$ & $\begin{array}{l}\text { Ideally, graded area slope (up or down) } \\
\text { will match that of runway shoulders. }\end{array}$ \\
\hline 11 & $\begin{array}{l}\text { Width of lateral } \\
\text { clear area }\end{array}$ & $79.5 \mathrm{~m}(260 \mathrm{ft})$ & $\begin{array}{l}\text { The lateral clear area is measured } \\
\text { outward from the outside edge of the } \\
\text { graded area. }\end{array}$ \\
\hline 12 & $\begin{array}{l}\text { Transverse slope } \\
\text { of lateral clear } \\
\text { area }\end{array}$ & $\begin{array}{l}12 \% \text { maximum } \\
\text { (up) }\end{array}$ & $\begin{array}{l}\text { Requirement is applied to imaginary } \\
\text { plane extending from the outer edge of } \\
\text { the graded area outward a distance of } \\
79.5 \mathrm{~m}(260 \mathrm{ft}) \text {. No object or surface } \\
\text { feature may penetrate this imaginary } \\
\text { plane. }\end{array}$ \\
\hline 13 & $\begin{array}{l}\text { Width of primary } \\
\text { surface }\end{array}$ & $244 \mathrm{~m}(800 \mathrm{ft})$ & $\begin{array}{l}\text { Centered on the runway centerline and } \\
\text { incorporates the runway, shoulder, } \\
\text { graded area, and lateral clear area. No } \\
\text { fixed or mobile objects may be located in } \\
\text { this area unless the item is fixed by } \\
\text { function and therefore a permissible } \\
\text { deviation. }\end{array}$ \\
\hline \multirow{4}{*}{14} & \multirow{4}{*}{$\begin{array}{l}\text { Distance between } \\
\text { centerlines of } \\
\text { parallel runways }\end{array}$} & $\begin{array}{l}305 \mathrm{~m} \\
(1,000 \mathrm{ft})\end{array}$ & $\begin{array}{l}\text { Visual flight rules (VFR) without } \\
\text { intervening parallel taxiway between the } \\
\text { parallel runways. One of the parallel } \\
\text { runways must be a VFR-only runway. }\end{array}$ \\
\hline & & $\begin{array}{l}633 \mathrm{~m} \\
(2,075 \mathrm{ft}) \\
\end{array}$ & VFR with intervening parallel taxiway. \\
\hline & & $\begin{array}{l}762 \mathrm{~m} \\
(2,500 \mathrm{ft})\end{array}$ & $\begin{array}{l}\text { Instrument flight rules (IFR) using } \\
\text { simultaneous operation (depart-depart) } \\
\text { (depart-arrival). }\end{array}$ \\
\hline & & $\begin{array}{l}1311 \mathrm{~m} \\
(4,300 \mathrm{ft}) \\
\end{array}$ & IFR using simultaneous approaches. \\
\hline 15 & $\begin{array}{l}\text { Width of USAF } \\
\text { mandatory zone } \\
\text { of frangibility }\end{array}$ & $\begin{array}{l}152.5 \mathrm{~m} \\
(500 \mathrm{ft})\end{array}$ & $\begin{array}{l}\text { Centered on the runway centerline. All } \\
\text { items sited within this area must be } \\
\text { frangible. }\end{array}$ \\
\hline 16 & $\begin{array}{l}\text { Length of USAF } \\
\text { mandatory zone } \\
\text { of frangibility }\end{array}$ & $\begin{array}{l}1829 \mathrm{~m} \\
(6,000 \mathrm{ft})\end{array}$ & $\begin{array}{l}\text { Centered on the runway. All items sited } \\
\text { within this area to the ends of the end } \\
\text { clear zone must be frangible. }\end{array}$ \\
\hline
\end{tabular}

Figure 25. Typical runway layout for unidirectional operations (not to scale) (FC 3-260-06F, Fig. 2-2).

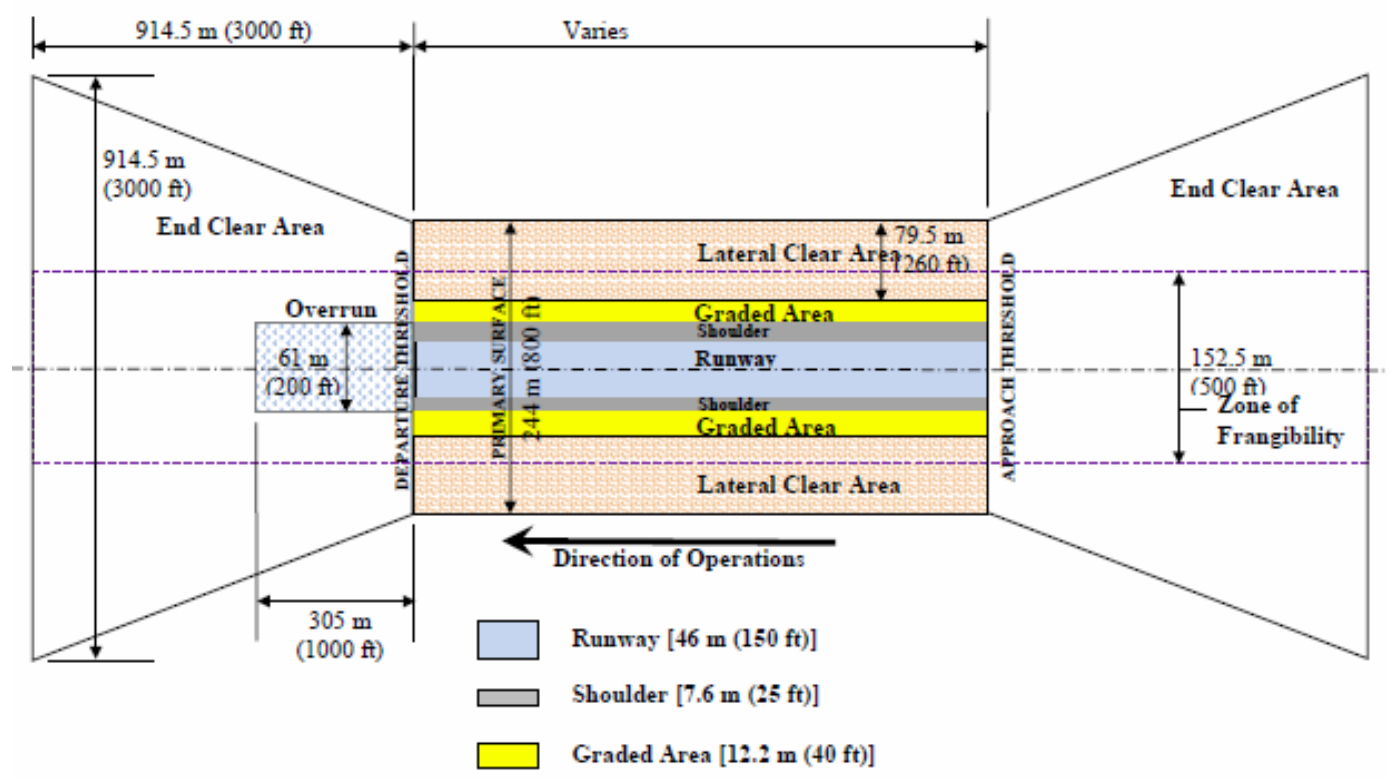




\subsubsection{Structural evaluation}

Appendix B of FC 3-260-06F provides the procedures for the structural evaluation of the two types of natural ice subsurfaces at McMurdo: glacial and sea ice. The calculations presented are specific to McMurdo but provide some relevant information. FC 3-260-06F Appendix B considers three failure modes: deformation, creep, and flexural.

\subsubsection{Glacial Ice}

Deformation Failure. The glacial ice surface must be shown to be capable of supporting C-130 and C-17 contact-pressure levels for heavy wheeled aircraft without compressive or shear failure. These capacities will be demonstrated by one of the two following methods, depending on the circumstances: proof rolling to detect zones of weakness or the experience of past operations. Because neither of these methods are applicable to contingency operations, this review will not discuss them further.

Creep Failure. Long-term parking at warm ice temperatures can lead to creep deformation of the glacial ice. At ice temperatures below $-4^{\circ} \mathrm{C}$ $\left(25^{\circ} \mathrm{F}\right)$, creep deformation is relatively slow. If aircraft will be parked for an extended time, then they will have to be moved periodically to avoid any difficulty during the initial rollout. Appendix B of FC 3-260-06F recommends that no more than $25 \mathrm{~mm}$ (1 in.) of deformation occur below a parked aircraft tire. In general, this limit will be reached in one hour at an ice temperature of $-2.5^{\circ} \mathrm{C}\left(27.5^{\circ} \mathrm{F}\right)$, two hours at $-5^{\circ} \mathrm{C}\left(23^{\circ} \mathrm{F}\right)$, and three hours at $-10^{\circ} \mathrm{C}\left(14^{\circ} \mathrm{F}\right)$.

Flexural Failure. The ice sheet at the Pegasus site is approximately $30 \mathrm{~m}$ (100 ft) thick. Depending on the temperature and crystallographic structure and impurities content of the ice, this ice has flexural strength on the order of 5 to $10 \mathrm{~kg} / \mathrm{cm}^{2}$ (490 to $980 \mathrm{kPa}$ or 75 to $150 \mathrm{psi}$ ). The large thickness of the ice sheet reduces the bending stresses in response to heavy wheeled aircraft to levels that can easily be carried by the ice. A PCASE analysis routine (PCASE is the Pavement-Transportation Computer Assisted Structural Engineering program used by the U.S. Army, Air Force, and Navy for design and evaluation of roads and airfields) for rigid Portland cement concrete, modified for glacial ice, was used to determine the minimum thickness of glacial ice needed to support the heaviest aircraft load (a fully burdened C-17) without flexural cracking. 
To be conservative, a flexural strength of only $0.4 \mathrm{~kg} / \mathrm{cm}^{2}(39.2 \mathrm{kPa}$ or $5.7 \mathrm{psi}$ ) was used (this value is based on the weakest ice found in the area). Also, the subbase material for this analysis is water because the Pegasus runway is floating on the sea. The results indicate that a C-17 at $263,600 \mathrm{~kg}(580,000 \mathrm{lb})$ gross load requires an ice thickness of $2.25 \mathrm{~m}$ (7.4 ft) for a safety factor of 1.0. Given that impurities and closed cracks certainly exist in the ice, Appendix B of FC 3-260-06F recommends a factor of safety of 3.0. Thus, the Pegasus runway should have an ice thickness of at least $6.8 \mathrm{~m}$ ( $22.3 \mathrm{ft}$ ) to support the anticipated aircraft and loads. Sea ice has a much greater flexural strength than glacial ice, so a significantly thinner layer of sea ice is sufficient to support aircraft.

The present $30 \mathrm{~m}$ (100 ft) thickness of ice at the site suffices for all anticipated aircraft operations. However, if the site experiences appreciable thinning or if FC 3-260-06F is used for another site or for aircraft other than the C-130 or C-17, a new analysis is prudent.

\subsubsection{Sea Ice}

Deformation Failure. A sea-ice surface must be shown to be capable of supporting C-130, C-17, and C-5 aircraft contact-pressure levels without compressive or shear failure. The primary sources of ice-surface weakness at a sea-ice runway site are melt pockets and brine-leaching features. When these occur, they may show minimal surface expression and may give the runway a deceptive appearance of strength. Rigorous maintenance, including the use of a reflective snowcap, can avoid melt problems. Brine leaching occurs as a function of time, and such weak areas may become prevalent if the runway is sited on progressively older (multi-year) sea ice. Generally, brine-leaching features will not reach a point of concern for a sea-ice runway until the ice is four years of age or older. If there is any doubt or if during runway operations the ice temperature exceeds $-5^{\circ} \mathrm{C}\left(23^{\circ} \mathrm{F}\right)$ for an exposed sea-ice surface or $-3^{\circ} \mathrm{C}\left(26.5^{\circ} \mathrm{F}\right)$ for a processed or loose snow surface, then a rigorous daily visual inspection, especially in the aircraft wheel tracks, is required. Any surface failure detected will require patching and recertification. Adequate surface strength will generally be demonstrated by some form of proof rolling to detect zones of weakness. This is again beyond the scope of contingency operations.

Flexural Strength. Flexural strength of sea ice is a function of ice temperature, ice thickness, and salinity. Correspondingly, the maximum load capacity of sea ice under aircraft loads is a function of flexural strength 
and the landing-gear-assembly geometry of each aircraft. Determining the maximum allowable aircraft load from ice thickness and temperature measurements establishes the load capacities for landings and takeoffs on a sea-ice runway. FC 3-260-06F provides nomographs to determine required sea-ice thickness based on 16 measurements of sea-ice thickness per site and ice temperature measurements at a minimum of four locations at a minimum depth of $150 \mathrm{~mm}$ ( $6 \mathrm{in}$.). This procedure is very much specific to the ice at McMurdo Station as there have been many years of measurements and aircraft operations.

Creep Failure. Long-term parking at high ice temperatures can lead to creep deformation of the sea ice. Long-term parking is defined here to mean any time an aircraft is stationary anywhere on sea ice for more than $30 \mathrm{~min}$. At ice temperatures below $-5^{\circ} \mathrm{C}\left(23^{\circ} \mathrm{F}\right)$, creep deformation is relatively slow. If aircraft will be parked for extended periods or very heavy loads or thin ice conditions are present, aircraft may have to be periodically moved to avoid excessive creep deformation of the sea ice. A maximum allowable deflection limit of $10 \%$ of the ice thickness has been set for parked aircraft per Appendix B of FC 3-260-06F. Field tests indicate no major cracking or failures on sea ice until deflections are in excess of $25 \%$ of the ice thickness (Vaudrey 1977). The 10\% deflection value was selected because this is the freeboard limit for the ice sheet; although the ice is safe at this point ( $10 \%$ deflection), water could penetrate through existing cracks and holes to the runway surface, raising concern and causing operational difficulties (Barthelemy 1992). Parking curves have been developed for each aircraft. The curves indicate the maximum time an aircraft can remain stationary as a function of the period (ice temperature), ice thickness, and aircraft type and load. The aircraft must change parking locations if it remains on the ice longer than indicated by the curves. The center of the new parking position must be at least $152.5 \mathrm{~m}$ ( $500 \mathrm{ft}$ ) from the original location.

\subsubsection{Surface conditions, preparation, and maintenance}

Surface preparations and maintenance guidance in FC 3-260-06F are written to include operations such as grading and rolling, which are beyond the scope of contingency airfields. It does not include specific dimensions for surface irregularities, such as undulations or potholes, that require maintenance. 


\subsection{Roughness}

In 2010, Lt. Col. Mark Doll, Air National Guard Directorate of Air and Space, reviewed the criteria for acceptable roughness of a snow or sea-ice runway to allow LC-130 operations. Appendix B presents his findings. The roughness of the runway affects the load-bearing capacity of the aircraft and potentially the airframe integrity of the aircraft. 


\section{Discussion}

Criteria produced by both the Air Force and Army are very specific about the requirements to land aircraft or drop cargo and personnel on unimproved LZs and DZs. The current survey, assessment, and approval methods mandated by FM 5-430-00-2, UFC 3-260-01, and AFI 13-217 call for personnel on the ground performing field tests and visual assessments.

Computer programs are able to analyze satellite imagery and select potential sites with the appropriate geometry and lack of obstructions, both natural and manmade (i.e., vegetation, bodies of water, significant changes in elevation, and infrastructure). However, the remote evaluation of surface characteristics such as bearing capacity, friction, and surface roughness, particularly in areas covered with ice and snow, needs further investigation.

\subsection{Unimproved soil LZs and DZs}

Arid environments typically yield the largest number of potential LZs for fixed-wing aircraft because of the small amount of vegetation. However, visual surveys and field measurements of vegetation cover and soil properties such as texture, density, moisture content, and strength show that surface condition and soil properties are critical factors limiting the potential of LZs to support aircraft operations in arid climates (Affleck et al. 2009).

One of the primary factors influencing the soil strength of LZs was moisture content. At certain sites, the moisture combined with the presence of poorly draining soils and a shallow water table significantly impacted the bearing capacity of the LZ. An LZ may have the capacity for aircraft operations during one season but that the same area may not be suitable in another season (Affleck et al. 2009). This is particularly true of regions that experience frost penetration and the resulting thaw weakening of frostsusceptible soils.

A specific interest is the need to better quantify the surface roughness (mounds, undulations, and swales) or to perhaps use another measure of roughness index and adapt an acceptable roughness value for LZs. UFC 3260-1 specifies that longitudinal grade changes cannot exceed 1.5\% measured at $61 \mathrm{~m}$ (200 ft) intervals. And AFI 13-217 indicates that soil mounds or depressions must be leveled or filled if greater than $15 \mathrm{in} .(38 \mathrm{~cm})$ 
across and 6 in (15 cm) in height or depth. Doll, through looking at artic operations, identified roughness criteria in graphic form (discussed below). However, assessment of these criteria, at this time, is only by manual elevation surveys of the ground surface. Additionally, seasonal roughness or surface irregularities due to frost heave have not been addressed.

In addition, friction and soil resistance on aircraft landing and take-off due to surface conditions and loose materials needs to be investigated. Work has been performed with the C-17 since the publication of ETL 97-9 with regard to both of these issues but to date has involved evaluation of these properties by instrumented vehicles and aircraft and conventional testing equipment (i.e., shear vanes, penetrometers, Clegg impact hammers, and density measurements) (Shoop et al. 1999, 2008; Tucker et al. 2009; Tingle et al. 2017).

For rotary-wing aircraft LZs and cargo and personnel DZs, the application of remote assessment may be easier because the requirements for the bearing capacity of the terrain are generally lower. For these sites, soil bearing capacity, surface friction, and roughness do not need to support fixed-wing aircraft landings; however, the terrain must still support the mission (delivery of soldiers, equipment, vehicles, etc.). Dust and debris may be an issue.

\subsection{Arctic LZs and DZs}

For LZ and DZ assessment in Arctic regions, the requirements are sparse to nonexistent. Typically, when siting an unimproved LZ in the Arctic and Antarctic, the surface would be underlain by either sea or glacial ice at the surface or under a very thin layer of snow. This was the case for the 2014 joint expedient skiway exercise between the Royal Canadian Air Force and the U.S. Air National Guard near Resolute Bay, Canada (Shoop et al. 2015). Arctic and Antarctic runways for wheeled aircraft, particularly those associated with McMurdo Station, are not located on deep snow without extensive runway construction, including snow strength measurements and proof rolling by heavy equipment prior to aircraft operations. Ski aircraft routinely land on open fields or minimally prepared snow surfaces, however.

Standard practice currently involves evaluating the thickness of existing ice. This is not a standard operational capability of remote-sensing programs. Research to remotely asses soil surfaces to estimate soil type and 
therefore to infer soil strength is progressing; and techniques to remotely sense snow properties or snow water equivalents for hydrologic studies can be used to infer some of the snow engineering qualities needed for siting LZs. Heat flow and land surface models are often used to predict ice, snow, or frost thickness based on temperature input; but these models do not predict engineering properties for typical cold regions earth materials and are not yet fully integrated into engineering assessments.

The ability to remotely assess potential sites with regard to depth of snow cover; surface friction; undulating, irregular, or rough ice surfaces; and subsurface voids within the ice may also be difficult and needs to be investigated further. This would include establishing the criteria for surface roughness as discussed by Doll (see Appendix B).

Doll's review identified roughness as an issue of both "bump" height and the distance between bumps or bump amplitude. This is briefly addressed in the FC-3-260-06C runway criteria, which indicates that longitudinal grade changes cannot exceed 1.5\% measured at $61 \mathrm{~m}$ (200 ft) intervals and, additionally, that the runway shall be checked for high-frequency, low amplitude undulations that degrade rideability and may decrease aircraft stopping performance.

FC-3-260-06C also references CRREL Monograph 98-1 (Blaisdell et al. 1998). Though CRREL was working with manual elevation surveys to evaluate a constructed runway surface, which is beyond the scope of unimproved LZ siting, both CRREL and Doll identified a figure from military specification MLL-A-8863C (U.S. Navy 1987), which provides criteria for surface roughness, applicable to both soil and snow/ ice runways (Figure 26).

Doll discusses similar work by Boeing on the quantification and measurement of runway roughness. Application of these criteria to unimproved surfaces and translation into remote assessment capabilities requires further refinement. Recently, the roughness of the new Phoenix compactedsnow runway, constructed in 2016 at McMurdo Station, was assessed using high-resolution GPS elevation data and FAA software; and this technique looks promising for the future (Shoop 2016). 
Figure 26. Runway surface roughness for landing and take-off (MIL-A-8863C, Fig. 1).

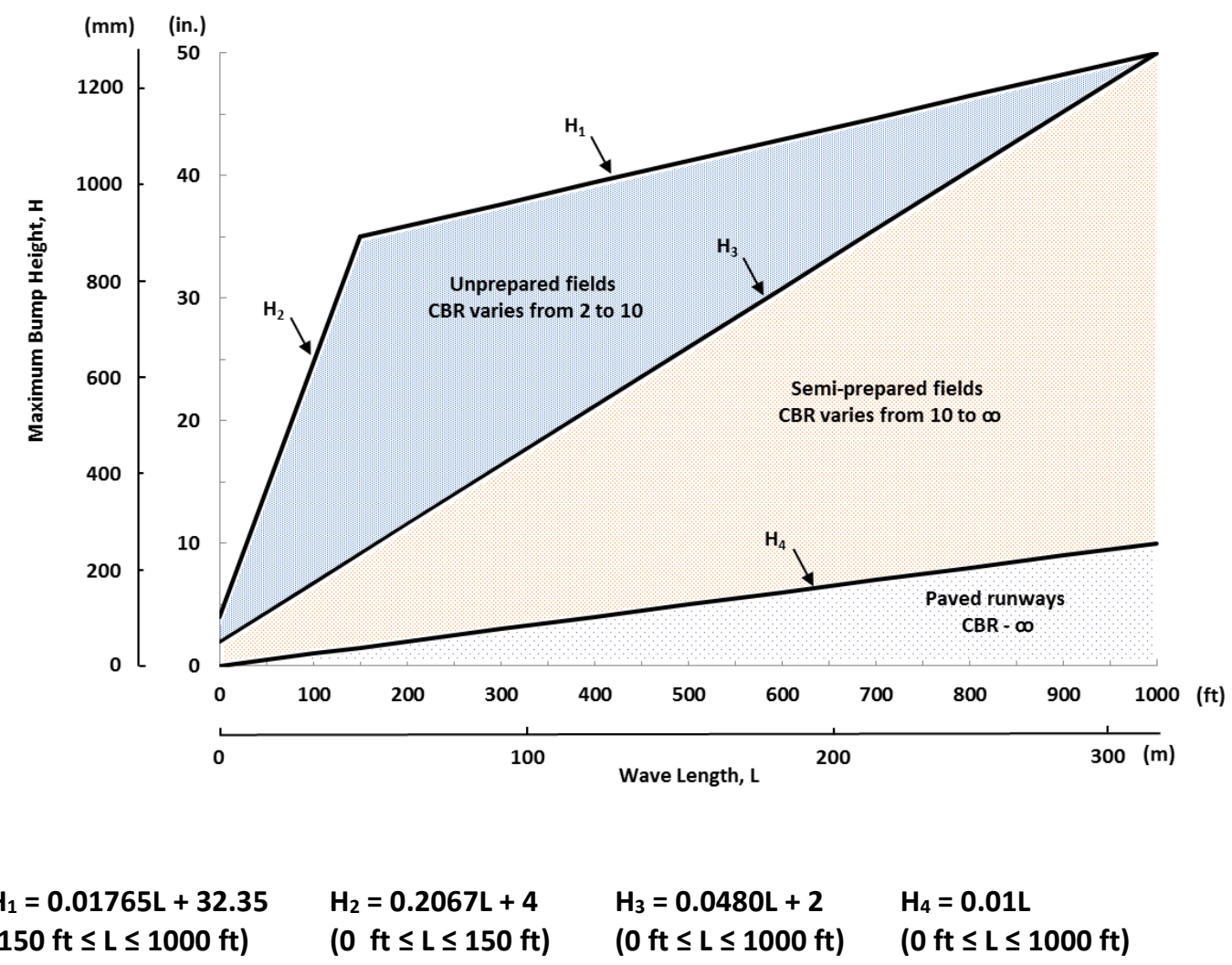

However, currently available imagery can be used to locate potential sites with dimensions large enough to establish LZs and DZs in the Arctic and Antarctic. The Canadian Ice Service is able to review Radarsat2 imagery and differentiate between areas of open water, rough mobile ice, and smoother more stationary ice (Shoop et al. 2015). Also, an initial assessment to confirm the absence of large, visible surface irregularities and to find a location with proximity to the shore lines or to the area of interest of the proposed operations is also within current capabilities. 


\section{Conclusions}

It is evident that a wealth of criteria exists for siting airfields in all types of locations not impacted by freeze, thaw, snow and ice. The current methods for assessing these criteria do not, however, necessarily lend themselves to remote operations. The military for years has depended on "boots on the ground" to provide assurance that sites are capable of supporting aircraft operations or airdrops of cargo or personnel without damage or loss of life.

However, with the evolution of technology, certain aspects of the potential LZ and DZ siting may lend themselves to remote assessment that would limit the number of personnel and time needed on-site prior to aircraft operations. Further work is needed in the areas of surface bearing capacity, friction, and roughness inference from remote indicators; seasonal variation of site properties; and application remote methods to sites with snow and ice surfaces. 


\section{References}

AFCEC (Air Force Civil Engineering Center). 2013. Minimum Airfield Operating Surface Selection and Repair Quality Criteria. ETL 13-3. Tyndall Air Force Base, FL: Air Force Civil Engineering Center.

_ 2015. Air Force Design, Construction, Maintenance, and Evaluation of Snow and Ice Airfields in Antarctica. FC 3-260-06F. Air Force Civil Engineering Center.

AFCESA (Air Force Civil Engineer Support Agency). 1997. Criteria for Design, Maintenance, and Evaluation of Semi-Prepared Airfields for Contingency Operations of the C-17 Aircraft. ETL 97-9. Tyndall Air Force Base, FL: Air Force Civil Engineer Support Agency.

— 2002a. Design, Construction, Maintenance, and Evaluation of the Pegasus Glacial Runway for Heavy Wheeled Aircraft Operations. ETL 02-16 (Superseded). Tyndall Air Force Base, FL: Air Force Civil Engineer Support Agency.

— 2002b. Airfield Pavement Evaluation Standards and Procedures. ETL 02- 19. Tyndall Air Force Base, FL: Air Force Civil Engineer Support Agency.

— 2002c. Design, Construction, Maintenance, and Evaluation of the McMurdo Sound (Antarctica) Sea Ice Runway for Heavy Wheeled Aircraft Operations. ETL 07-12 (Superseded). Tyndall Air Force Base, FL: Air Force Civil Engineer Support Agency.

—. 2008a. Airfield and Heliport Planning and Design. UFC 3-260-01. Washington, DC: Air Force Civil Engineer Support Agency.

_ 2008b. Structural Evaluation Procedure for Stabilized Soil-Surfaced Airfields. ETL 08-14. Tyndall Air Force Base, FL: Air Force Civil Engineer Support Agency.

_ 2009a. Contingency Airfield Pavement Specification. ETL 09-2. Tyndall Air Force Base, FL: Air Force Civil Engineer Support Agency.

_. 2009b. C-130 and C-17 Landing Zone(LZ) Dimensional, Marking, and Lighting Criteria. ETL 09-6 (Change 1). Tyndall Air Force Base, FL: Air Force Civil Engineer Support Agency.

Affleck, R. T., C. C. Ryerson, and L. A. Barna. 2008. Assessment of Opportune Landing Sites at El Centro NAF and Fort Bliss. In Transportation Systems 2008 Workshop, Phoenix, AZ, 21- 24 April. CD-ROM. Omaha, NE: USACE Transportation Systems Center.

Affleck, R., L. Barna, S. Shoop, and C. Ryerson. 2009. Estimating Bearing Capacity for Opportune Landing Sites. In Bearing Capacity of Roads, Railways and Airfields, ed. E. Tutumluer and I. L. Al-Qadi, 1019-1028. New York: CRC Press.

Barna, L. A., R. T. Affleck, and C. C. Ryerson. 2008. Assessment of Opportune Landing Sites in Southeastern Indiana. In Transportation Systems 2008 Workshop, Phoenix, AZ, 21- 24 April. CD-ROM. Omaha, NE: USACE Transportation Systems Center. 
Barthelemy, J . 1992. Nomographs for Operating Wheeled Aircraft on Sea-Ice Runways: McMurdo Station, Antarctica. In Proceedings of the 11th International Conference on Offshore Mechanics and Arctic Engineering, Calgary, Alberta, Canada, 7-12 June, 4:27-33. American Society of Mechanical Engineers.

Blaisdell, G. L., R. M. Lang, G. Crist, K. Kurtti, R. J . Harbin, and D. Flora. 1998. Construction, Maintenance, and Operation of a Glacial runway, McMurdo Station, Antarctica. CRREL Monograph 98-1. Hanover, NH: U.S. Army Cold Regions Research and Engineering Laboratory.

Canadian Air Command. 1982. Air Transport Group Ice Strip Requirements for CC 130 Hercules, CC 115 Buffalo and CC 138 Twin Otter Operations. CFACM 10-100. Ottawa, Canada: Canadian Air Command.

Danyluk, L. S., S. A. Shoop, R. T. Affleck, and W. L. Wieder. 2008. Opportune Landing Site CBR and Low-Density Laboratory Database. ERDC/ CRREL TR 08-9. Hanover, NH: U.S. Army Engineer Research and Development Center.

DoD (Department of Defense). 2015. Air Installations Compatible Use Zones. DoD Instruction 4165.57. Washington, DC: Department of Defense http://www.dtic.mil/whs/directives/corres/pdf/416557p.pdf.

Doll, M. 2010. Allowable Skiway Roughness for LC-130 Operations between 125,000 lbs and 135,000 lbs. J oint Base Andrews, MD: Air National Guard Directorate of Air and Space Operations.

FAA (Federal Aviation Administration). 2012. DRAFT Airport Design. FAA AC 150/5300-13A. Washington, DC: Federal Aviation Administration. https://www.faa.gov/documentLibrary/media/Advisory_Circular/draft_150_5300_13a.pdf.

Rollings, M. P., L. Barna, and R. S. Rollings. 2004. Expedient Military Airfields in Cold Climates. In Proceedings of the Transportation Systems Workshop, Fort Lauderdale, FL, 28 March- 2 April.

Shoop, S., P.W. Richmond, and R. Eaton. 1999. Estimating Rolling Friction of Loose Till for Aircraft Take-off on dirt Runways. In Proceedings of the 13th International Conference of the ISTVS, Munich, Germany, 14- 17 September, 421- 428.

Shoop, S., B. Coutermarsh, J . Priddy, and I. Maldonado. 2008. Methods for Characterizing Loose Till on Unsurfaced Airfields. In Transportation Systems 2008 Workshop, Phoenix, AZ, 21- 24 April. CD-ROM. Omaha, NE: USACE Transportation Systems Center.

Shoop, S. A. 2016. National Science Foundation Briefing. J uly 11. Hanover, NH: U.S. Army Engineer Research and Development Center.

Shoop, S. A., C. Ryerson, R. Affleck, J . Buska, and J . Kost. 2008. Predicting Soil Strength for Opportune Landing Sites. In Transportation Systems 2008 Workshop, Phoenix, AZ, 21- 24 April. CD-ROM. Omaha, NE: USACE Transportation Systems Center. 
Shoop, S. A., T. Melendy, B. Tracy, J . Stanley, C. Souza, M. Sala, and R. Thivierge. 2015. Expedient Skiway Reconnaissance and Operations near Resolute Bay, Canada. Cold Regions Engineering 2015, 476- 487. New York, NY: American Society of Civil Engineers.

Sopher, A. M., S. A. Shoop, J . M. Stanley, and B. T. Tracy. 2016. Image Analysis and Classification Based on Soil Strength. ERDC/ CRREL TR 16-13. Hanover, NH: U.S. Army Engineer Research and Development Center.

Tingle, J . S., G. J . Norwood, and B. Cotter. 2017. Prediction of Runway Condition Rating (RCR) on Unpaved Runways Using Continuous Friction Measurement Equipment. Presented at the Transportation Research Board 96th Annual Meeting. Washington, DC: Transportation Research Board. http://docs.trb.org/prp/17-05996.pdf.

Transport Canada. 2011. Ice Aerodrome Development-Guidelines and Recommended Practices. AC 301-003. Civil Aviation. Ottawa, ON: Transport Canada.

Tucker, A. A., C. E. Childers, and R. J . Poremski. 2009. Getting Dirty: Testing C-17 Airfield Performance in Dirt and Mud Landing Zones. AFFTC-PA-09023. Edwards Air Force Base, CA: Air Force Flight Test Center.

USACE (U.S. Army Corps of Engineers). 2001. Pavement Design for Airfields. UFC 3260-02. Washington, DC: U.S. Army Corps of Engineers.

U.S. Air Force. 1994. Planning and Design of Roads, Airfields, and Heliports in the Theater of Operations-Airfield and Heliport Design. U.S. Army FM 5-430-002/ AFJ PAM 32-8013, Vol II. Washington, DC: Department of the Army, Department of the Air Force.

— 2005. Computed Air Release Point Procedures. AFI 11-231. Washington, DC: Department of the Air Force.

— 2007. Drop Zone and Landing Zone Operations. AFI 13-217. Washington, DC: Department of the Air Force.

—. 2011. C-17 Operations Procedures. AFI 11-2C-17, Vol. 3. Washington, DC: Department of the Air Force.

2012. C-130 Operations Procedures. AFI 11-2C-130, Vol. 3. Washington, DC: Department of the Air Force.

_ 2013. C-17A Antarctic Operations. AFI 11-2C-17, Vol. 3, Addenda -C. Washington, DC: Department of the Air Force.

— 2016. Facility Requirements. AFMAN 32-1084. Washington, DC: Department of the Air Force.

U.S. Navy. 1987. Airplane Strength and Rigidity Ground Loads for Navy Acquired Airplanes. MIL-A-8863C (AS). Lake Hurst, NJ : Naval Air Warfare Center Aircraft Division Lakehurst, Aircraft Systems Requirements Department. 
Vaudrey, K. D. 1977. Ice Engineering: Study of Related Properties of Floating Sea-Ice Sheets and Summary of Elastic and Visco-Elastic Analyses. Technical Report R860. Port Hueneme, CA: Naval Civil Engineering Lab. 


\section{Appendix A: FAA AC 150/5300-13A, Appendix 2, Wind Analysis}

\section{A2-1. Objective. *}

This appendix provides guidance on the assembly and analysis of wind data to determine runway orientation. It also provides guidance on analyzing the operational impact of winds on existing runways.

a. Wind is a key factor influencing runway orientation and the number of runways. Ideally, a runway should be aligned with the prevailing wind. Wind conditions affect all aircraft in varying degrees. Generally, the smaller the aircraft, the more it is affected by wind, particularly crosswind components (Figure A2-1) which are often a contributing factor in small aircraft accidents.

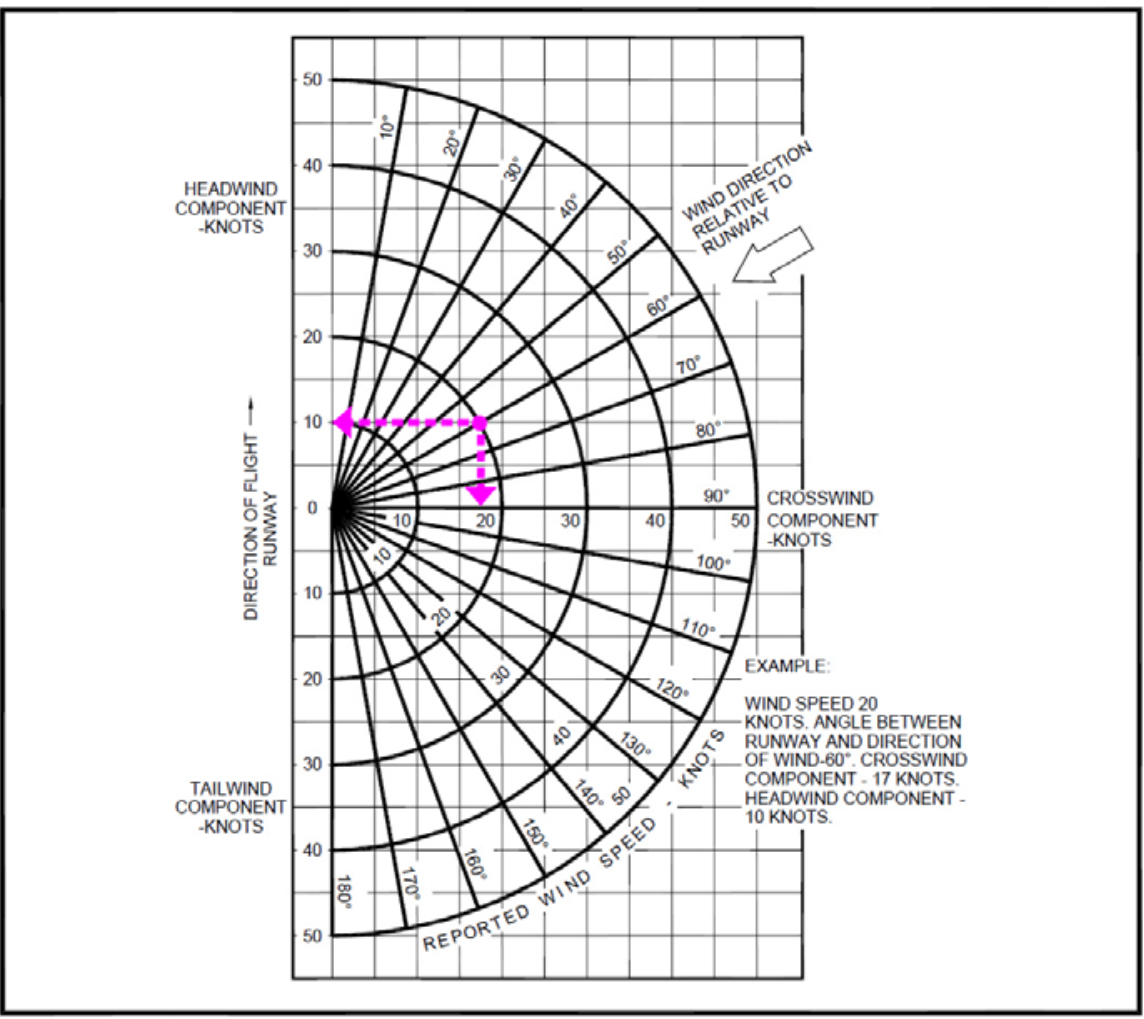

Figure A2-1. Wind vector diagram

\footnotetext{
* Section, table, and figure numbering retained from the original document
} 
b. Airport planners and designers should make an accurate analysis of wind to determine the orientation and number of runways at an airport. Construction of two runways may be necessary to achieve the desired 95.0 percent wind coverage. The correct application of the results of the wind data analysis will add substantially to the safety and utility of the airport.

\section{A2-2. Crosswinds.}

The crosswind component of wind direction and velocity is the resultant vector which acts at a right angle to the runway. It is equal to the wind velocity multiplied by the trigonometric sine of the angle between the wind direction and the runway direction. The wind vector triangles may be solved graphically as shown in Figure A2-1. From this diagram, one can also determine the headwind and tailwind component for combinations of wind velocities and directions.

\section{A2-3. Allowable crosswind components.}

When a runway orientation provides less than 95.0 percent wind coverage for the aircraft which are forecast to use the airport on a regular basis, a crosswind runway may be required. The allowable crosswind component(s) for each Runway Design Code (RDC), which are used to determine the percentage of wind coverage, are shown in Table 3-1 [from the main body of FAA AC 150/5300-13A, reproduced below. A discussion of the FAA RDC system is beyond the scope of this report. Please see FAA AC 150/5300-13A for details.]

Table 3-1. Allowable crosswind component per Runway Design Code (RDC).

\begin{tabular}{|c|c|}
\hline RDC & $\begin{array}{c}\text { Allowable Crosswind } \\
\text { Component }\end{array}$ \\
\hline A-I and B-I* & 10.5 knots \\
\hline A-II and B-II & 13 knots \\
\hline A-III, B-III, & 16 knots \\
C-I through D-III & \\
\hline D-I through D-III & 20 knots \\
\hline A-IV and B-IV, & \\
C-IV through C-VI, & \\
\hline D-IV through DOVI & 20 knots \\
\hline
\end{tabular}

*Includes A-I and B-I small aircraft. 


\section{A2-4. Coverage and orientation of runways.}

The most advantageous runway orientation based on wind is the one which provides the greatest wind coverage with the minimum crosswind components. Wind coverage is the percent of time crosswind components are below an acceptable velocity. The desirable wind coverage for an airport is 95 percent, based on the total numbers of weather observations during the record period, typically 10 consecutive years. The data collection should be undertaken with an understanding of the objective; i.e., to attain 95 percent utility of the runway and/ or airport. At many airports, aircraft operations decline after dark, and it may be desirable to analyze the wind data on less than a 24-hour observation period. At airports where operations are predominantly seasonal, you should consider the wind data for the predominant-use period. At locations where provision of a crosswind runway is impractical due to severe terrain constraints you may need to consider increasing operational tolerance to crosswinds by upgrading the airport layout to the next higher $\mathrm{RDC}$.

\section{A2-5. Assembling wind data.}

The latest and most reliable wind information should always be used to carry out a wind analysis. A record which covers the last 10 consecutive years of wind observations is recommended. Records of lesser duration may be acceptable on a case-by-case basis, but this should be discussed with and agreed to by the FAA Airports Region/ District Office prior to proceeding. In some instances, it may be highly desirable to obtain and assemble wind information for periods of particular significance; e.g., seasonal variations, instrument weather conditions, daytime versus nighttime, and regularly occurring gusts.

\section{A2-6. Data source.}

The best source of wind information is the National Oceanic and Atmospheric Administration, National Climatic Data Center (NCDC). The NCDC is located at:

Climate Services Branch

National Climatic Data Center

151 Patton Avenue

Asheville, North Carolina 28801-5001

Tel: 828-271-4800 / Fax: 828-271-4876

Public Web Address: www.ncdc.noaa.gov 
The NCDC no longer provides wind data in the FAA format. However, the hourly data is now available free of charge at the following website: www1.ncdc.noaa.gov/ pub/ data/ noaa/ . Data will require conversion to the FAA format to use in the FAA windrose program. You will need to determine the ceiling, visibility, and whether you want VMC [Visual Meteorological Conditions], IMC [Instrument Meteorological Conditions], allweather or all wind data for your location. The wind summary for the airport site should be formatted with the standard 36 wind sectors (the NCDC standard for noting wind directions) and the wind speed groupings shown in Figure A2-2. An existing wind summary of recent vintage may be acceptable for analysis purposes if these standard wind direction and speed groupings are used. Figure A2-3 is an example of a typical wind summary.

a. Data not available. In those instances when NCDC data are not available for the site, it may be possible to develop composite wind data using wind information obtained from two or more nearby recording stations. However, exercise caution because the composite data may have limited value if there are significant changes in the topography (such as hills/mountains, bodies of water, ground cover, etc.) between the sites. Limited records should be augmented with personal observations (wind-bent trees, interviews with the local populace, etc.) to ascertain if a discernible wind pattern can be established.

b. When there is a question on the reliability of or lack of wind data, it may be necessary to obtain onsite wind observations. If the decision is made to obtain onsite wind data, the recommended monitoring period should be at least one year to produce reliable data. One year will usually be adequate to determine the daily wind fluctuations and seasonal changes for the site. Airport development should not proceed until adequate wind data have been acquired. 


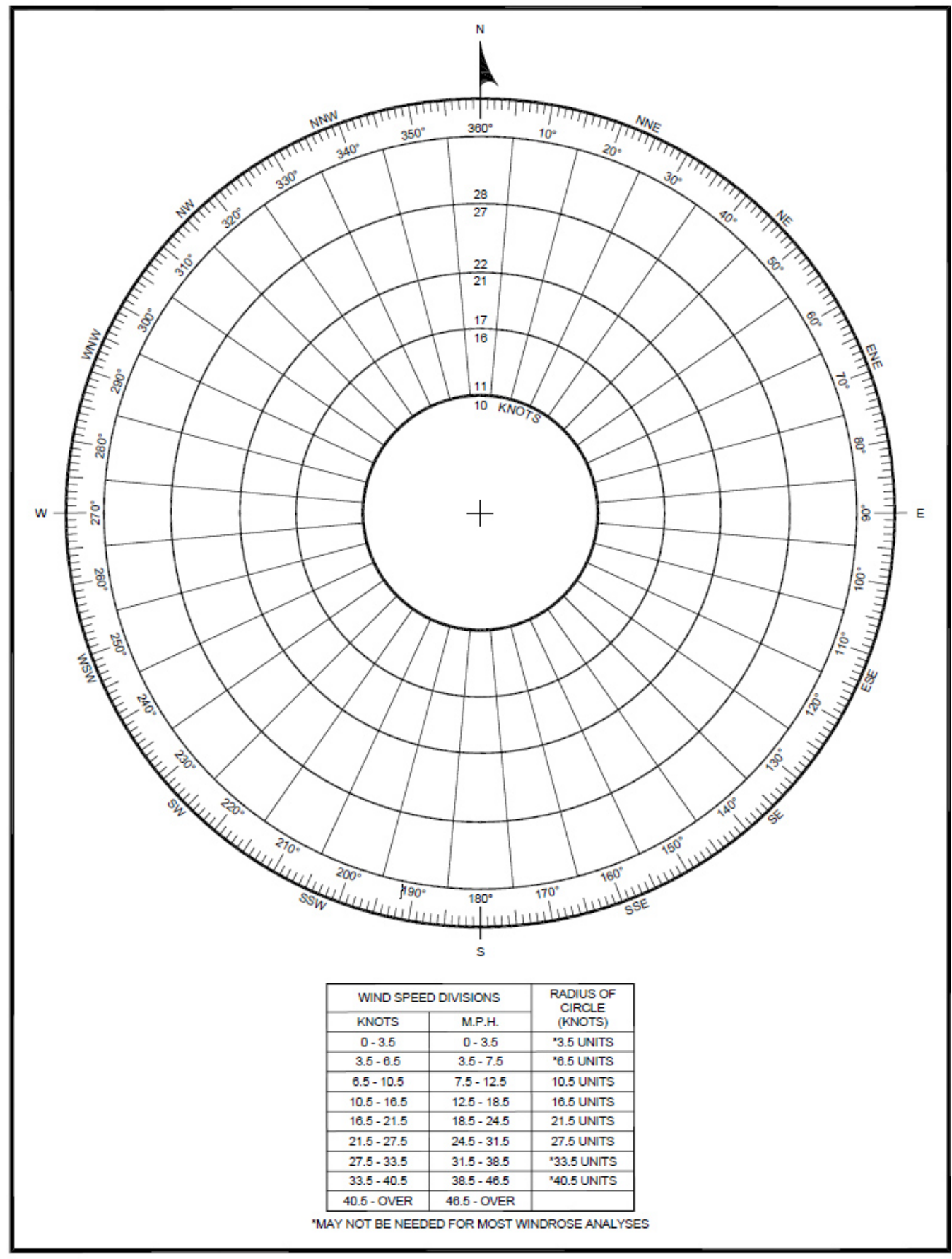

Figure A2-2. Blank windrose showing direction and divisions 


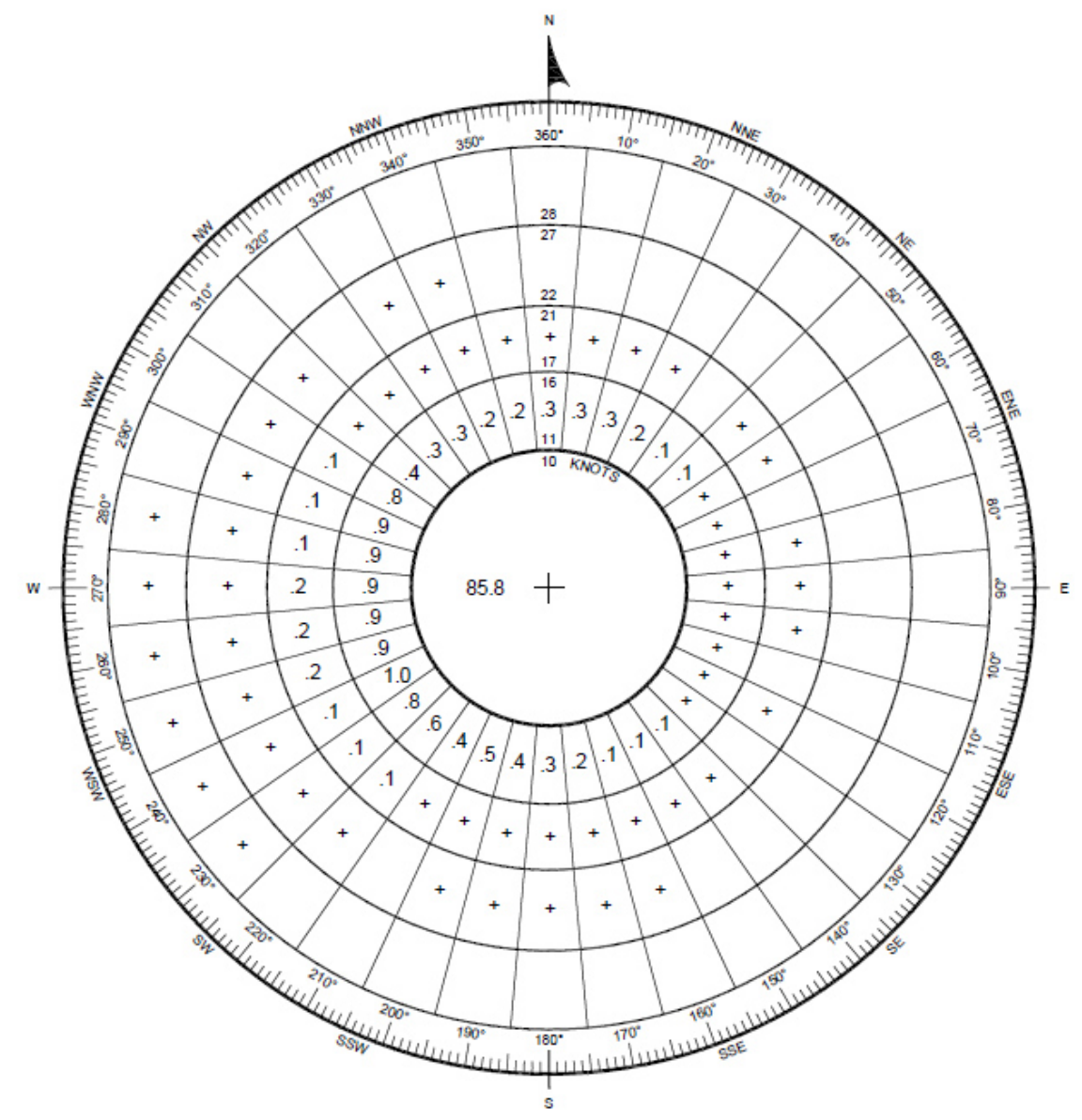

Figure A2-3. Completed windrose using Figure A2-1 data

\section{A2-7. Analyzing wind data.}

The most common wind analysis procedure uses a windrose which is a scaled graphical presentation of the wind information. 
a. Drawing the windrose. The standard windrose (Figure A2-2) is a series of concentric circles cut by radial lines. The perimeter of each concentric circle represents the division between successive wind speed groupings (Figure A2-2). Radial lines are drawn dividing the windrose into 36 wind sectors so that the area of each sector is centered on the direction of the reported wind.

b. Plotting wind data. Each segment of the windrose represents a wind direction and speed grouping corresponding to the wind direction and speed grouping on the NCDC summary. The recorded directions and speeds of the wind summary are converted to a percentage of the total recorded observations. Computations are rounded to the nearest onetenth of 1 percent and entered in the appropriate segment of the windrose. Figure A2-4 illustrates a completed windrose analysis based on data from Figure A2-3. Plus (+) symbols are used to indicate direction and speed combinations which occur less than one-tenth of 1 percent of the time.

c. Crosswind template. A transparent crosswind template is a useful aid in carrying out the windrose analysis (Figure A2-4). The template is essentially a series of three parallel lines drawn to the same scale as the windrose. The allowable crosswind component for the runway as determined by the RDC establishes the physical distance between the outer parallel lines and the centerline. When analyzing the wind coverage for a runway orientation, the design crosswind limit lines can be drawn directly on the windrose.

Note: NCDC wind directions are recorded on the basis of true north. The magnetic runway headings will be determined based on the magnetic declination for the site.

d. Analysis procedure. The purpose of the analysis is to determine the runway orientation which provides the greatest wind coverage within the allowable crosswind component limits. This can be readily estimated by rotating the crosswind template about the windrose center point until the sum of the individual segment percentages appearing between the outer "crosswind limit" lines is maximized. It is accepted practice to total the percentages of the segments appearing outside the limit lines and to subtract this number from 100. For analyses purposes, winds are assumed to be uniformly distributed throughout each 
of the individual segments. Figure A2-3 and Figure A2-4 illustrate the analysis procedure as it would be used in determining the wind coverage for a runway, oriented 90-270 degrees, intended to serve all types of aircraft. The wind information is from Figure A2-3. Several trial orientations may be needed to determine the orientation which maximizes wind coverage.

Table A2-1. Standard wind analysis results for ALL_WEATHER

\begin{tabular}{|c|c|c|c|c|c|c|c|c|c|c|}
\hline TITLE: & Anytown. & USA & & & & & & & & \\
\hline & & $\overline{\text { RUNWA }}$ & $\overline{\text { ORIEN }}$ & ATION: & & 270 & DEGRE & & & \\
\hline & & CROSSV & $\mathrm{NDCO}$ & PONEN & & 13 & KNOTS & & & \\
\hline & & TAILWI & $\mathrm{D} \mathrm{COM}$ & NENT: & & 60 & KNOTS & & & \\
\hline & & & IIND CC & ERAGE & & $7.79 \%$ & & & & \\
\hline & & HOURI & $\overline{O B S E F}$ & $\overline{A T I O N}$ & $\overline{\mathrm{OF} W I}$ & SPEEI & (KNOT: & & & \\
\hline DIRECTION & $0-3$ & $4-6$ & $7-10$ & $11-16$ & $17-21$ & $22-27$ & $28-33$ & $34-40$ & $>41$ & TOTAL \\
\hline $10^{\circ}$ & 174 & 652 & 586 & 247 & 6 & 0 & 0 & 0 & 0 & 1665 \\
\hline $20^{\circ}$ & 213 & 816 & 698 & 221 & 7 & 0 & 0 & 0 & 0 & 1955 \\
\hline $30^{\circ}$ & 235 & 894 & 656 & 158 & 4 & 0 & 0 & 0 & 2 & 1949 \\
\hline $40^{\circ}$ & 167 & 806 & 559 & 88 & 0 & 0 & 0 & 0 & 0 & 1620 \\
\hline $50^{\circ}$ & 182 & 809 & 345 & 44 & 1 & 0 & 0 & 0 & 0 & 1381 \\
\hline $60^{\circ}$ & 199 & 753 & 332 & 30 & 5 & 0 & 0 & 0 & 0 & 1319 \\
\hline $70^{\circ}$ & 158 & 550 & 187 & 20 & 0 & 0 & 0 & 0 & 1 & 916 \\
\hline $80^{\circ}$ & 134 & 453 & 194 & 22 & 1 & 0 & 0 & 0 & 0 & 804 \\
\hline $90^{\circ}$ & 145 & 373 & 169 & 16 & 2 & 0 & 0 & 0 & 0 & 705 \\
\hline $100^{\circ}$ & 103 & 321 & 115 & 19 & 1 & 0 & 0 & 0 & 2 & 561 \\
\hline $110^{\circ}$ & 92 & 293 & 138 & 25 & 0 & 0 & 0 & 0 & 0 & 548 \\
\hline $120^{\circ}$ & 90 & 283 & 207 & 33 & 3 & 0 & 0 & 0 & 0 & 616 \\
\hline $130^{\circ}$ & 93 & 279 & 188 & 28 & 0 & 0 & 0 & 0 & 0 & 588 \\
\hline $140^{\circ}$ & 65 & 246 & 195 & 55 & 2 & 0 & 0 & 0 & 1 & 564 \\
\hline $150^{\circ}$ & 64 & 213 & 194 & 42 & 4 & 0 & 0 & 0 & 0 & 517 \\
\hline $160^{\circ}$ & 61 & 236 & 201 & 105 & 16 & 1 & 0 & 0 & 1 & 621 \\
\hline $170^{\circ}$ & 80 & 254 & 306 & 140 & 10 & 2 & 0 & 0 & 1 & 793 \\
\hline $180^{\circ}$ & 88 & 372 & 485 & 194 & 25 & 2 & 0 & 0 & 0 & 1166 \\
\hline $190^{\circ}$ & 125 & 499 & 608 & 278 & 17 & 2 & 0 & 0 & 0 & 1529 \\
\hline $200^{\circ}$ & 184 & 717 & 700 & 370 & 27 & 2 & 0 & 0 & 0 & 2000 \\
\hline $210^{\circ}$ & 264 & 950 & 725 & 331 & 26 & 0 & 0 & 0 & 2 & 2298 \\
\hline $220^{\circ}$ & 321 & 1419 & 1030 & 445 & 40 & 5 & 0 & 0 & 0 & 3260 \\
\hline $230^{\circ}$ & 396 & 1658 & 1355 & 630 & 97 & 9 & 1 & 0 & 0 & 4146 \\
\hline $240^{\circ}$ & 415 & 1600 & 1465 & 782 & 83 & 13 & 2 & 0 & 1 & 4361 \\
\hline $250^{\circ}$ & 323 & 1166 & 1093 & 730 & 119 & 33 & 5 & 0 & 0 & 3469 \\
\hline $260^{\circ}$ & 311 & 979 & 918 & 715 & 139 & 23 & 4 & 0 & 0 & 3089 \\
\hline $270^{\circ}$ & 248 & 760 & 810 & 660 & 143 & 28 & 3 & 0 & 0 & 2652 \\
\hline $280^{\circ}$ & 226 & 625 & 815 & 666 & 105 & 14 & 2 & 0 & 0 & 2453 \\
\hline $290^{\circ}$ & 162 & 572 & 865 & 710 & 98 & 11 & 0 & 0 & 0 & 2418 \\
\hline $300^{\circ}$ & 130 & 470 & 788 & 590 & 68 & 5 & 0 & 0 & 0 & 2051 \\
\hline $310^{\circ}$ & 82 & 394 & 659 & 325 & 31 & 1 & 0 & 0 & 0 & 1492 \\
\hline $320^{\circ}$ & 97 & 302 & 485 & 246 & 15 & 0 & 0 & 0 & 0 & 1145 \\
\hline $330^{\circ}$ & 66 & 281 & 450 & 196 & 6 & 1 & 0 & 0 & 0 & 1000 \\
\hline $340^{\circ}$ & 85 & 265 & 369 & 151 & 4 & 1 & 0 & 0 & 0 & 875 \\
\hline $350^{\circ}$ & 102 & 314 & 323 & 152 & 12 & 0 & 0 & 0 & 0 & 903 \\
\hline $360^{\circ}$ & 140 & 394 & 457 & 223 & 16 & 0 & 0 & 0 & 0 & 1230 \\
\hline Calm & 18705 & & & & & & & & & 18705 \\
\hline TOTAL & 24725 & 21968 & 19670 & 9687 & 1133 & 153 & 17 & 0 & 11 & 77364 \\
\hline
\end{tabular}




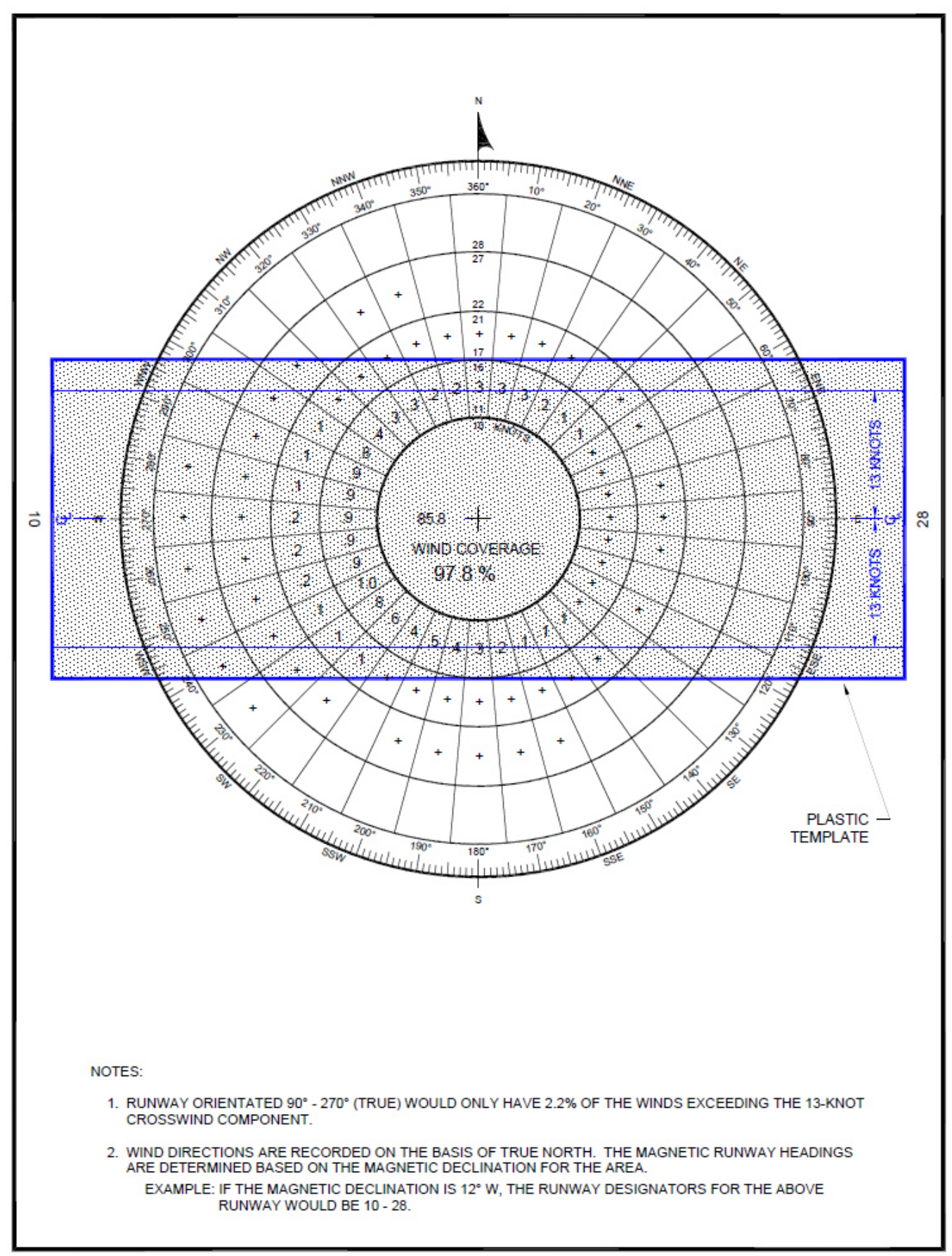

Figure A2-4. Windrose analysis

\section{A2-8. Conclusions.}

The example wind analysis shows that the optimum wind coverage possible with a single runway and a 13-knot crosswind component is 97.8 percent. If the analysis had shown that it was not possible to obtain at least 95.0 percent wind coverage with a single runway, then consideration 
should be given to provide an additional (crosswind) runway oriented to bring the combined wind coverage of the two runways to at least 95.0 percent.

\section{A2-9. Assumptions.}

The analysis procedures assume that winds are uniformly distributed over the area represented by each segment of the windrose. The larger the area, the less accurate is this assumption. Calculations made using nonstandard windrose directions or speeds result in a derivation of wind coverage (and its associated justification for a crosswind runway) which is questionable.

\section{A2-10. Automated wind analysis tools.}

Wind analysis is typically done using computer programs. Wind analysis tools are available on the FAA Airport Surveying - Geographic Information System (GIS) Program website: https:/ / airports-gis.faa.gov/ public/index.html. 


\title{
Appendix B: Allowable Skiway Roughness for LC-130 Operations between 125,000 lbs and 135, 000 lbs (Doll 2010)
}

\author{
Lt. Col. Mark Doll, Air National Guard Directorate of Air and \\ Space, J oint Base Andrews, MD
}

\section{Introduction}

The purpose of this report is to establish surface roughness criteria in order to conduct LC-130 operations above the customary weight limits for a new site. While there is an acknowledged risk associated with landing above the customary initial-landing weight limits, this report aims to provide guidance in two ways. The first is to reduce overall risk to the aircrew and aircraft by reducing the number of sorties to the site; and the second is to expand the capabilities of the LC- 130 by providing tangible measures by which a ski landing area control officers (SLACOs) or pilot can judge a landing site. The ultimate goal is to provide a guide for skiway construction teams and a description of the necessary information that aircrew should look for before the initial landing.

\section{Background}

Presently, there is little quantitative guidance for determining the capability and suitability of ski landing area for conducting LC-130 operations. Current LC-130 regulations merely limit gross weight for open snow operations without regard for actual surface conditions. Current practice owes much to pilot judgment for determining the acceptability of a landing site and the ability of the LC- 130 to operate at gross weights above the operational open-snow limit of 125,000 lbs. This subjective assessment is solely based on personal experience gained through years of operating on a variety of sites, with no knowledge of the actual loads imposed on the aircraft or the acceptable limit loads of the LC-130. In addition, the current routine is to consider any new landing site as an open-snow site whether it is virgin ungroomed snow, or perfectly groomed but never used by LC-130s. Subsequent increases in aircraft gross weight could only be accomplished after first-hand inspections of the landing site. 
Since pilot judgment normally requires a pilot to have either inspected the site prior to LC- 130 operations, or during an actual LC-130 landing - neither of which is practical for the planned Casey mission - this document will propose roughness criteria for the Casey skiway in advance of actual LC-130 landings or inspection by SLACOs; with the intent of allowing an initial gross weight up to 135,000 lbs.

This document is not intended to supplant regulations or supersede good judgment.

\section{Survey and Discussion of Known Guidance}

It is considered useful to study other known guidance surrounding the subject of runway construction and repair, seeing as the specific directives for LC-130s are very limited. Even though much of the material is dated or obsolete, it has relevance due to the fact that the ski-equipped C-130 design is almost 50 years old; any changes in the design have only served to strengthen the airframe and skis. Known guidance and criterion are discussed in terms of relevancy, then analyzed for applicability to tactical aircraft and/ or the LC- 130 .

The only objective criteria for the roughness capability of the LC-130 is the following paragraph extracted from Technical Order (T.O.) 1C-130(L)H-1, the LC-130 Flight Manual:

"Ski operations at gross weights from 135,000 pounds to155,000 pounds, are restricted to smooth runways and taxiways which have been graded to provide a surface free of hardened snow drifts, ice blocks, pressure ridges, mounds of snow, sastrugi, and changes in elevation exceeding 4 inches in 20 feet."

This paragraph only addresses operations at or above 135,000lbs gross weight. Since the planned landing weight at Casey Station will be between 125,000 and 135,000 lbs, this paragraph technically will not apply, but it does provide an upper boundary for the highest weight considered in this paper.

A review of current and past DoD documents yielded the following information related to runway roughness, construction and repair. 
- AFI 11-2C-130V3, C-130 Operations Procedures, 23 April 2012: No guidance for airfield or ski landing area surface roughness.

- $\quad$ AFI 13-217, Drop Zone and Landing Zone Operations, 10 May 2007: Paragraph 3.5 provides general guidance on surface tolerances with one specific parameter: Soil mounds and potholes that exceed 15 inches across or 6 inches deep must be leveled or filled. No specific guidance for size and spacing of mounds or potholes, nor any references for snow surfaces. Not applicable since the skis can bridge a 15inch pothole.

- AFI 32-1041, Airfield Pavement Evaluation Program, 25 April 1994: Provides guidance for measuring roughness, but does not provide criteria to judge the suitability of a runway for any particular aircraft.

- AFPAM 10-219 V4, Airfield Damage Repair Operations, 28 May 2008, and T.O. 35E2-4-1 Repair Quality Criteria (RQC) charts G1 and G2 for C-130E/H: This pamphlet provides guidance and procedures for repairing war-damaged airfield operating surfaces. In conjunction with charts G1 and G2, it gives C-130-specific guidance for the acceptable height of a repair patch given the length of the patch and spacing from the adjoining patches. See Figures B1 and B2. Note that the charts assume the maximum aircraft gross weight of 155,000 lbs. An interesting point to mention is that these charts account for the airframe response to aerodynamic and cyclic gear loading. AFPAM 10-219V4 explains the procedure to use G1 and G2. For the purpose of this paper, we can neglect portions of the charts and only use the sections labeled "PATCH SPACING (FEET)." The x-axis is the distance from the threshold of the landing surface, and the y-axis is the patch spacing in feet. The area inside is divided into regions with the number representing the maximum patch height in inches. " $F$ " means flush; and "FF" means flushflush, indicating that patches on patches must all be flush. For example, using Figure B1 for C-130E/H takeoff at 155,000lbs, at 2000 feet from the threshold with a patch spacing of 200 feet, the patch must be flush-flush. However, a patch on the same location with spacing of 500 feet can have a height of 5 inches. The conclusion for this document is that for a 155,000 lb C-130, virtually any patch with a spacing of less than 200 feet must be flush with the primary surface. Since there is no consideration for lower aircraft weights, this is considered only as guidance for heavy weights. 
Figure B1. Repair Quality Criteria extracted from T.0. 35E2-4-1 for a C-130E/H take-off at 155,000 lbs. The red line overlies the 200 -foot Patch Spacing line. The area under the line indicates any runway patches spaced $\leq 200$ feet must be flush with the surface.

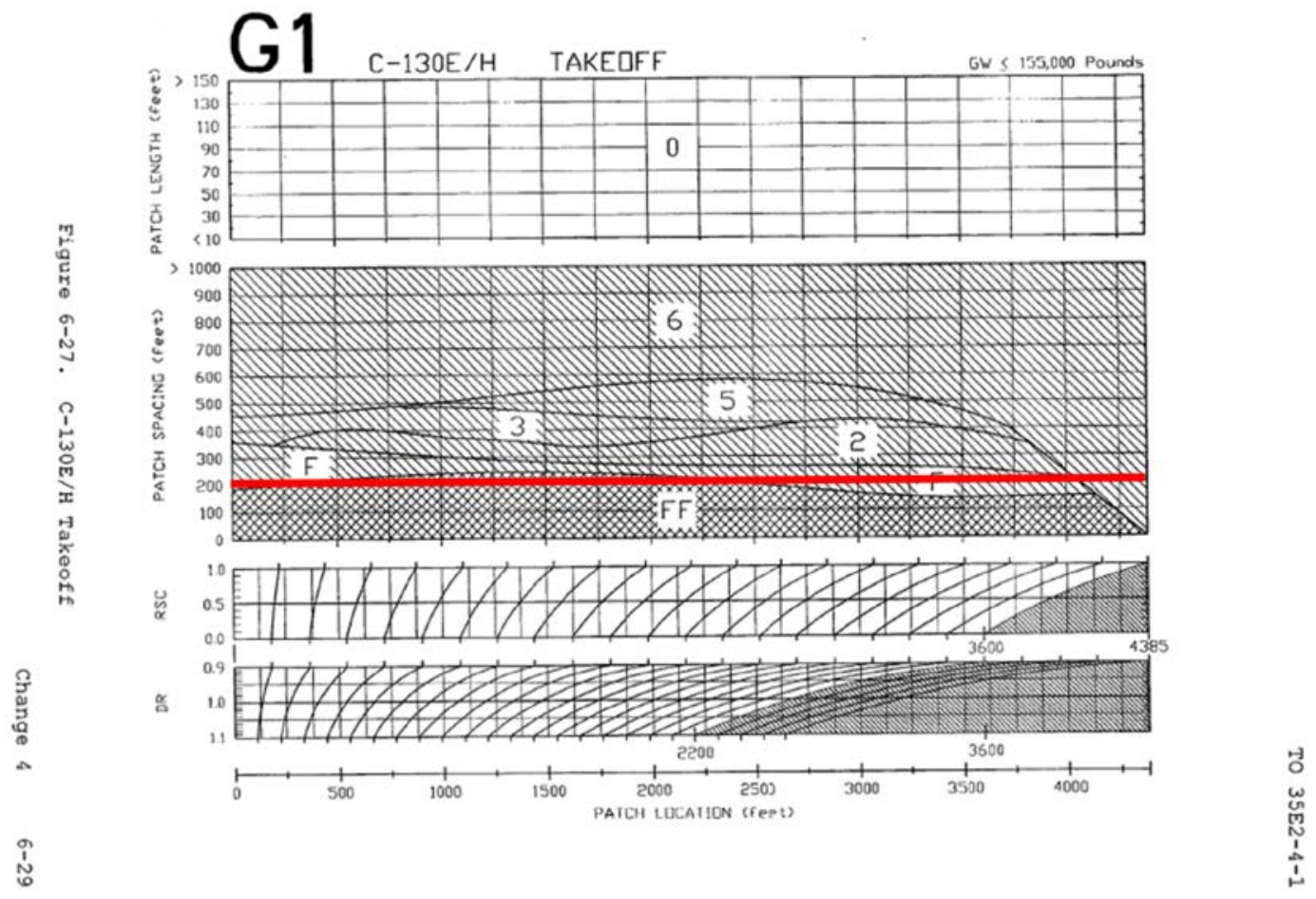

Figure B2. Repair Quality Criteria extracted from T.0. 35E2-4-1 for a C-130E/H landing at $155,000 \mathrm{lbs}$. The red line overlies the 200 -foot Patch Spacing line. The area under the line indicates any runway patches spaced $\leq 200$ feet must be flush with the surface.

ì

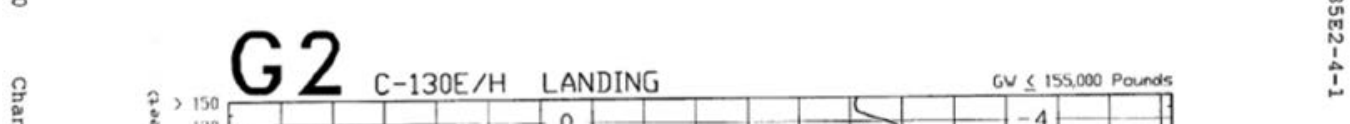


- Unified Facilities Criteria 3-130-3, Runway and Road Design: Arctic and Subarctic Construction, 16 J anuary 2004: Concerned with surface hardness and bearing capacity. No mention of surface roughness criteria.

- Unified Facilities Criteria 3-260-1, Airfield and Heliport Planning and Design, 17 November 2008: General guidance on planning and designing runways, to include runway slope and grade changes; with criteria specific to the C-130 and C-17 for special use war-fighting and contingency airfields as follows. The maximum longitudinal grade cannot exceed $3 \%$ and must be held to the minimum practicable, the maximum grade change allowed is $1.5 \%$ per $200 \mathrm{ft}$, the minimum distance be tween grade changes is 400 feet, and no grade change is allowed within 500 feet of the runway ends. This translates to a bump wavelength of at least 1200 feet assuming the worst-case scenario. No reference to surface roughness or short-wave undulations.

- Unified Facilities Criteria 3-260-2, Airfield Pavement Design for Airfields, 30 J une 2001: No reference to surface roughness.

- Unified Facilities Criteria 3-260-3, Airfield Pavement Evaluation, 15 April 2001: Covers load-carrying capacity and allowable traffic for different types of pavement. No objective roughness criteria.

- Unified Facilities Criteria 3-260-16FA, Airfield Pavement Condition Survey Procedures, 16J anuary 2004: Demonstrates various methods to survey airfield conditions. Only relevant measure for surface roughness is definition of a "medium severity" swell which is greater than 0.75-1.5 inches; and a "high severity" swell is greater than 1.5 inches. No indication of type of aircraft operating on the runway. This criteria falls below the 4-inch limit of the LC-130 Flight Manual. This is apparently a conservative measure to accommodate large nontactical aircraft.

- Unified Facilities Criteria 3-270-07, Airfield Damage Repair, 12, August 2002. Methods to repair airfield pavements. References T.O 35E24-1 for surface roughness criteria.

- MIL-A-8862, Airplane Strength and Rigidity Landplane Landing and Ground Loads, 18 May, 1960: This document defined the test criteria 
for USAF aircraft to determine their suitability for operational use. It has since been cancelled and replaced by MIL-A-8863C; yet it is often referenced in current studies including those of Boeing, the FAA, and the U.S. Army Corps of Engineers Cold Regions Research and Engineering Laboratory. It provides guidance for acceptable bump heights and wave lengths for Air Force paved, semi-prepared and unprepared airfields. This information is plotted on Figure B3.

- MIL-A-8863C Airplane Strength and Rigidity Ground Loads for Navy-Acquired Airplanes, 19 J uly, 1993: Obsolete document that technically only applied to Navy aircraft. However, it does provide similar information and supports ML-A-8862 in that the runway roughness criteria provided is not simply a maximum recommended for safe operations; it is what a Navy aircraft must be tested against for operational service. An interesting note is that ski-equipped aircraft are included, but there is no specific reference to the LC-130. Also note that a "paved" runway assumes an infinite CBR, a semi-prepared airfield assumes a CBR between 10 and infinity, and an unprepared airfield has a CBR between 2 and 10. These criteria are also plotted on Figure B3. (Surfaces with a CBR of 10 have a compressive strength of 75psi and are suitable for wheeled C-130 operations)

- FM 5-430-00-2/AFJ PAM32-8013 V2, 29 Sept 1994, Planning and Design of Roads, Airfields, and Heliports in the Theater of Operations Airfield and Heliport Design: Obsolete document. Same gradient criteria as UFC 3-260-1.

Non-DoD References:

- Boeing Commercial Airplane Group report D6-81746, Runway Roughness Measurement, Quantification, and Application - The Boeing Method: This is an excellent source for the background of runway roughness studies and aircraft design considerations. Figure B4 displays Boeing's allowable roughness criteria along with the MLL-A-8862 "Paved Airfields" line, together with the limited FAA and ICAO guidance. While this information is good for comparison, it is purely intended for large, nontactical, commercial aircraft. Thus the Boeing criteria will not be given further consideration. 
Figure B3. Composite roughness capability chart displaying criteria of the LC-130 Flight Manual, MIL-A-8862, MIL-A-8863 and the Lockheed Report.

\section{COMPOSITE ROUGHNESS CAPABILITY}

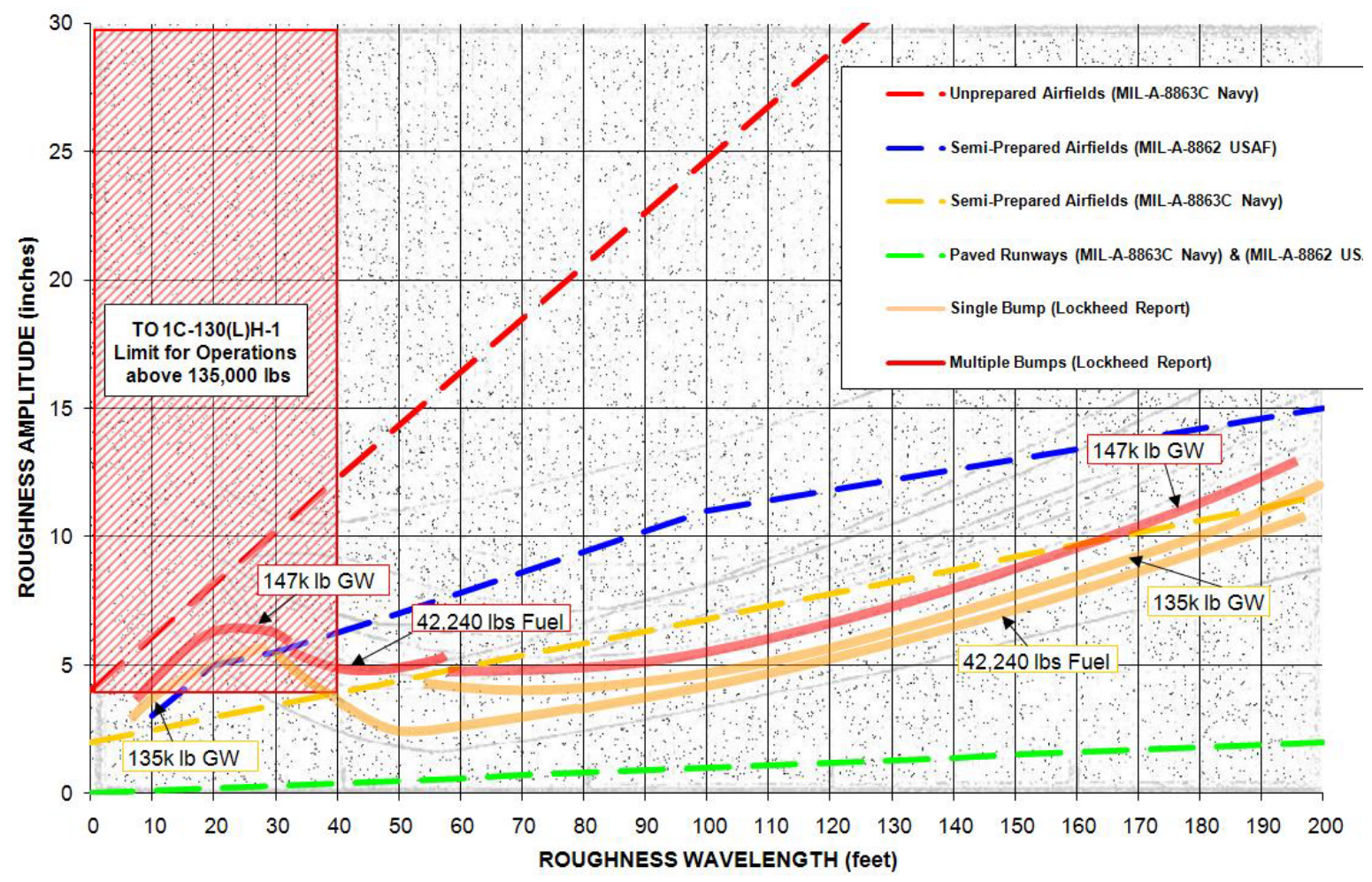

Figure B4. Boeing Chart consolidating different sources. Note that the "Bump Length" in this chart only includes one-half the longitudinal length of the bump or one-half the length of a wave..

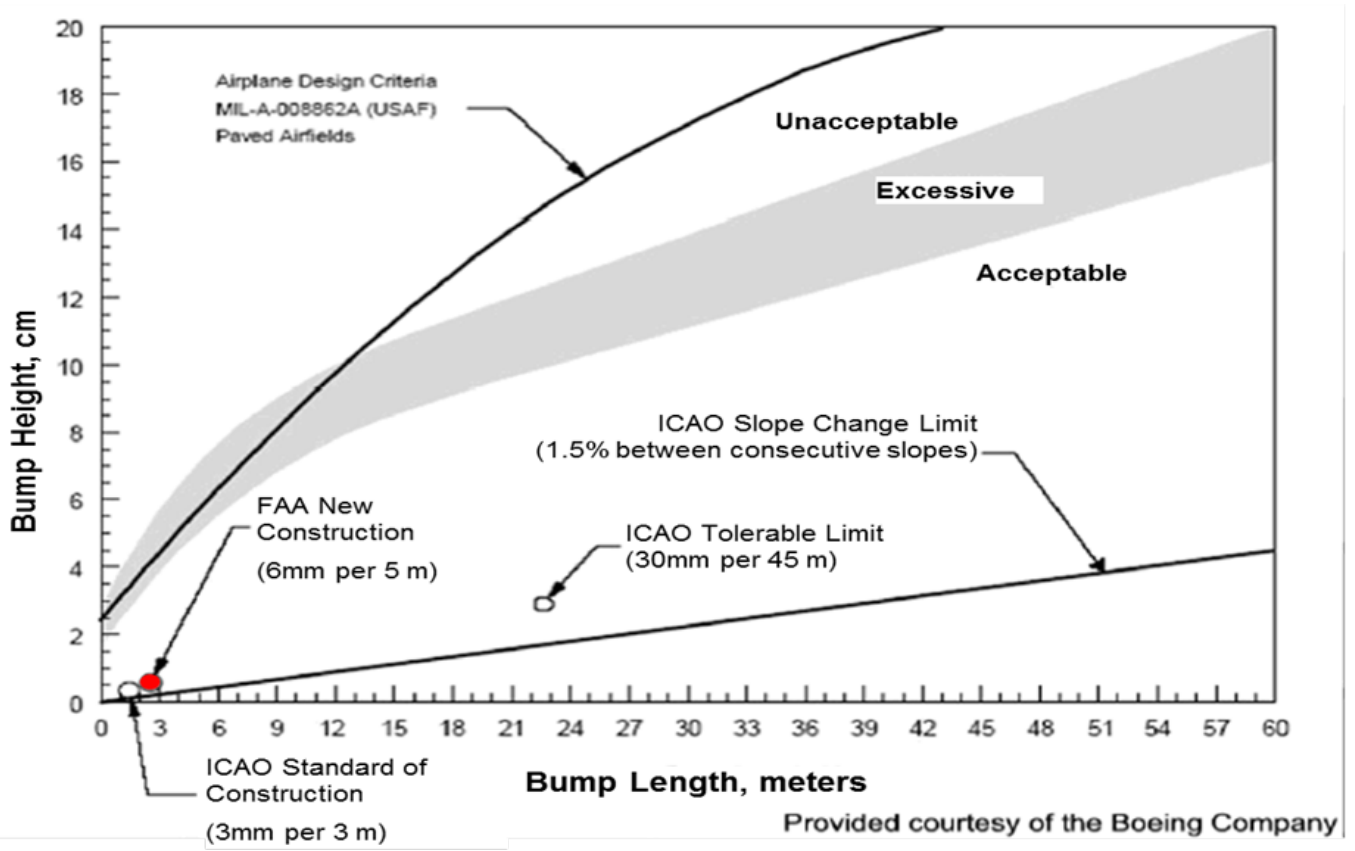


- Federal Aviation Administration: The FAA offers much guidance regarding airfield planning, pavement construction, maintenance and repair. Unfortunately, there is little guidance on runway roughness except Advisory Circular 150/5380-9, Guidelines and Procedures for Measuring Airfield Pavement Roughness, 30 September 2009: This recently-published document mirrors the Boeing Method. There is no consideration for semi-prepared airfields or tactical aircraft. Thus it will not be given further consideration.

- American Institute of Aeronautics and Astronautics: AIAA has published a handful of reports concerning methods to predict aircraft responses to dynamic ground loads. There is no data for C-130-type aircraft, nor any recommendations for roughness criteria.

- NASA: NACA/NASA has several reports on aircraft response to dynamic loads on landing gear travelling over undulations and heaves, though there is little on acceptable levels of roughness. Nevertheless, NASA Memorandum 2-21-59L, Study of Taxiing Problems Associated with Runway Roughness, March 1959, contains the following passage: "Since landing gears transmit the greatest loads when the impressed frequencies are between 1.5 and 2 cycles per second, the critical runway wave length corresponding to any given taxi speed can now be defined. If the speed range from 20 to 130 knots is considered, the critical wave lengths are found to lie between 17 and 150 feet. This region is of greatest concern, since the landing-gear response will be much reduced outside this range." The Lockheed report named in the next citation shows that the LC-130 landing gear and wing resonant frequencies are on the order of 1-2 cycles per second. Knowing that LC-130 flying speeds are above 120 knots, we only need to consider bump wavelengths $\leq 200$ feet.

- Lockheed: Through the development of the ski-equipped C-130A, C130BL (LC-130F) and the LC-130R, Lockheed performed extensive structural testing to measure the loads on the landing gear, skis and wings imposed by operating on uneven snow surfaces. These tests generally measured the loads while operating on "rough" snow surfaces, without correlating the loads to the actual snow conditions or roughness. While most of the original test reports are no longer available, they are well summarized in Lockheed Report LG77ER0005, Estab- 
lishment of Roughness Criteria for LC-130 Antarctic Operations, J anuary 1977. This report was commissioned by the U.S. Navy to establish roughness criteria for both the LC-130F and LC-130R. While it is not regulatory, this report is an excellent source of information, and should serve as a guide for future LC-130H operations. Further discussions will generally focus on this report.

Lockheed used an analytical approach to determine the roughness criteria using many of the old ski-equipped C-130 structural test reports as the foundation of their models. The report progresses through a summary of the old reports, then details the mathematical models used to predict critical airframe loads due to uneven surfaces. Unique to this report, the analysis considers resonant frequencies of the landing gear and wings for various gross weights and fuel loads. Then it advances to calculate peak loads for different bump heights and speed-wavelength combinations. The outcome is a series of charts representing the acceptable bump heights and wavelengths that should not exceed the acceptable limit loads. The four charts for the LC-130R are copied below, Figures B5 - B8.

Figure B5. Single bump capability for wing loads, LC-130R.

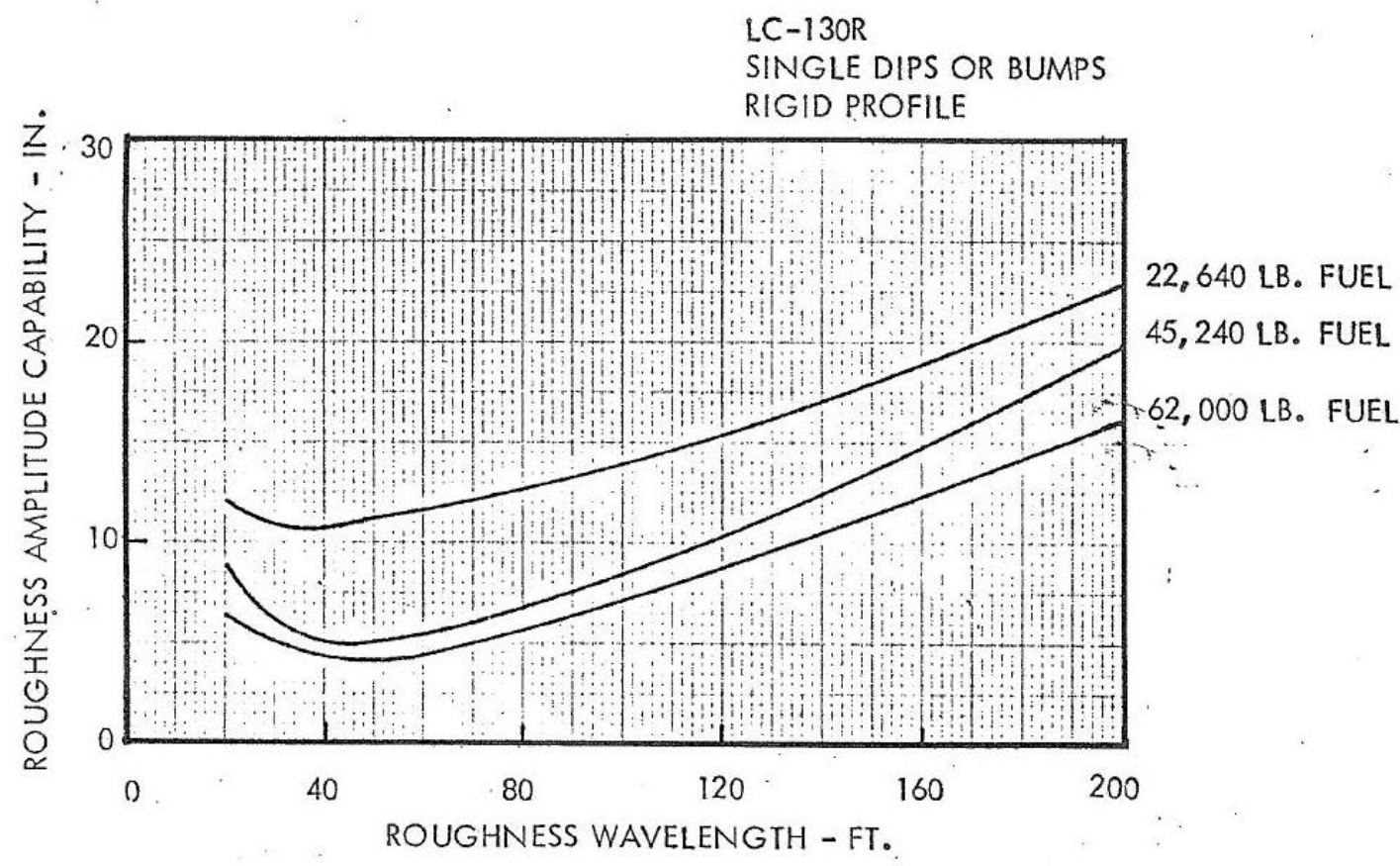


Figure B6. Multiple bump capacity for wing loads, LC-130R.

LC-130R

MULTIPLE DIPS OR BUMPS

RIGID PROFILE.

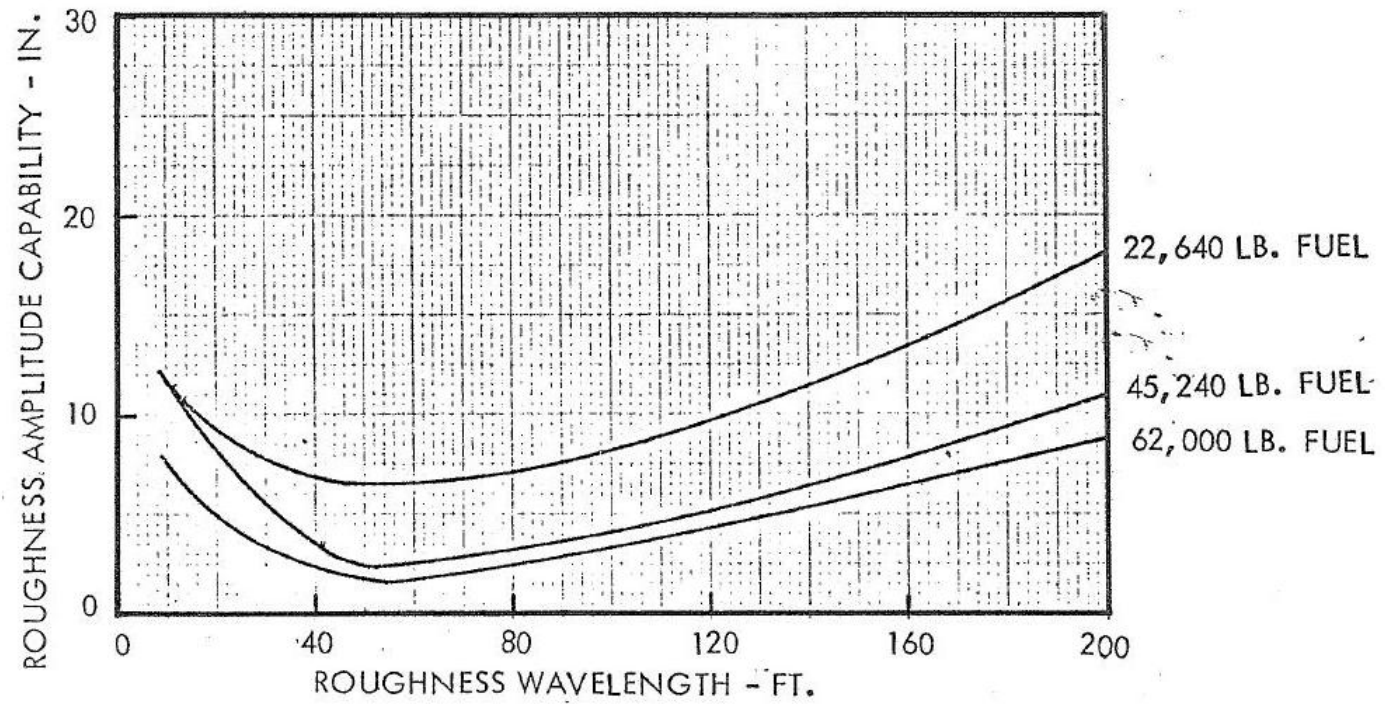

Figure B7. Single bump capacity for landing gear loads, LC-130R.

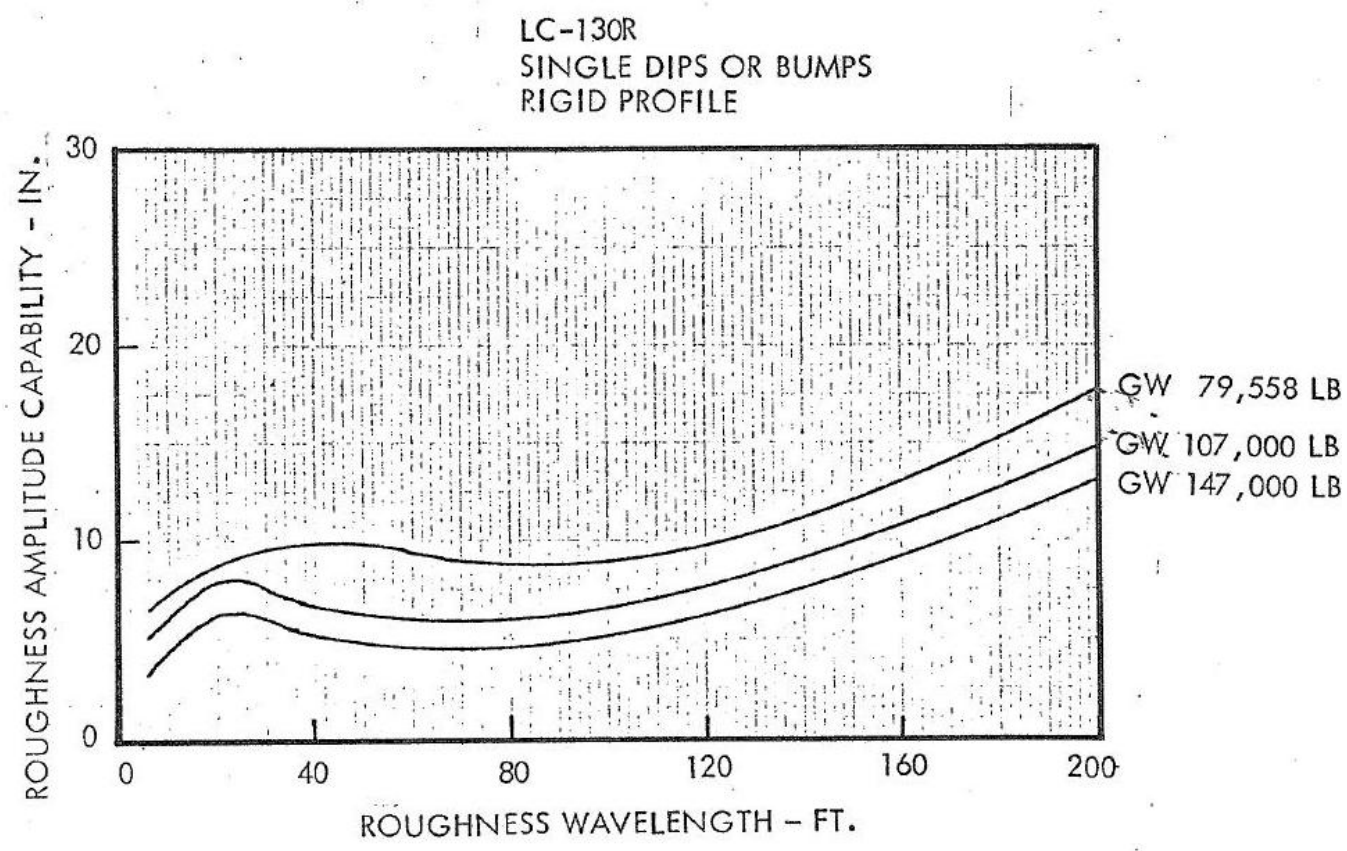


Figure B8. Multiple bump capacity for landing gear loads, LC-130R.

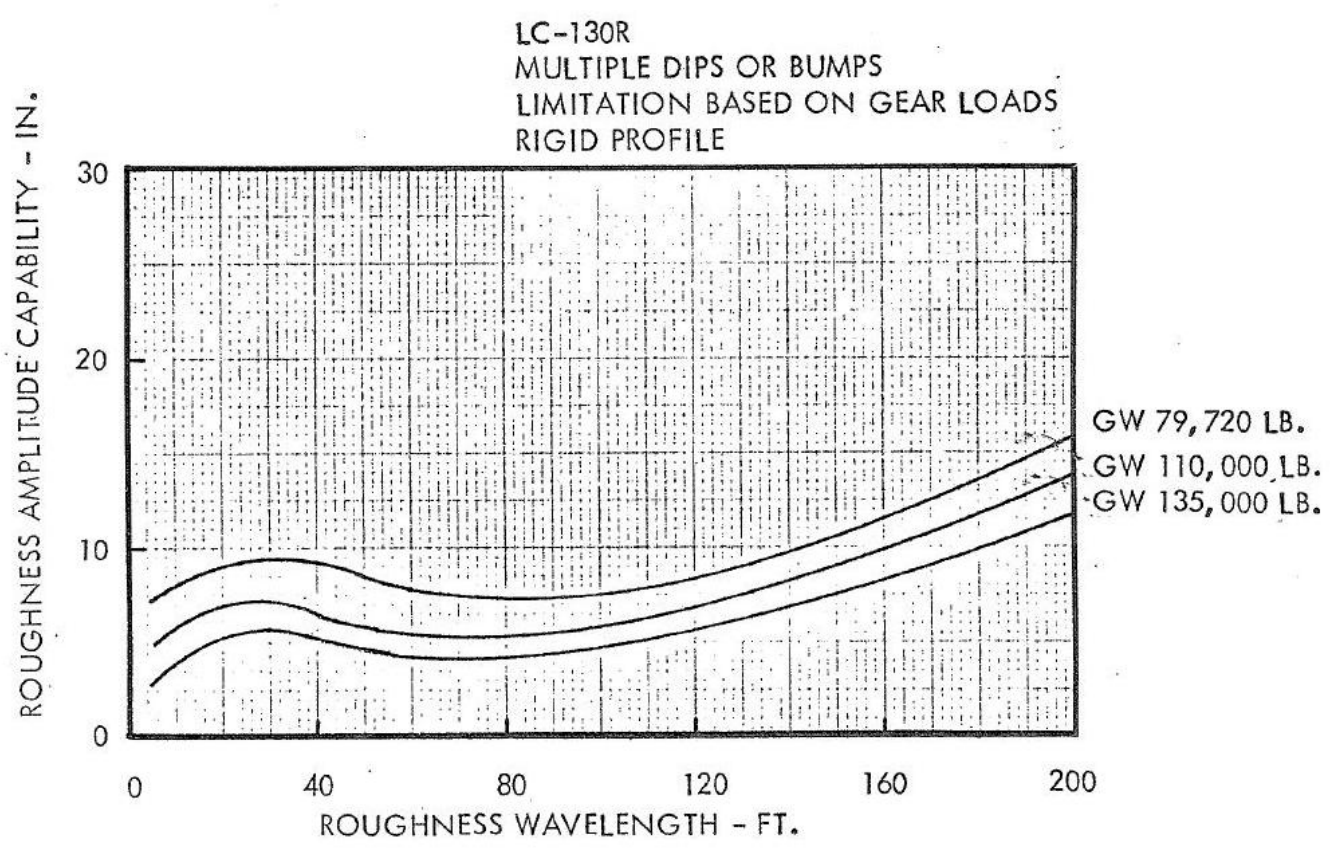

For further analysis we will assume a max gross weight of 135,000 lbs and a max fuel weight of 45,000 lbs for both take-off and landing. In view of the fact that each of these charts presents a limiting case somewhere across the spectrum of amplitudes and wavelengths, we must consider each one into the complete analysis. The simplest method was to overlay each chart and determine the limiting case, see Figure B9. 
Figure B9. Figures B5-B8 superimposed to determine limiting cases for either 135,000 lbs gross weight, or 45,000 lbs fuel weight. The yellow line represents multiple bumps and the red represents single bumps.

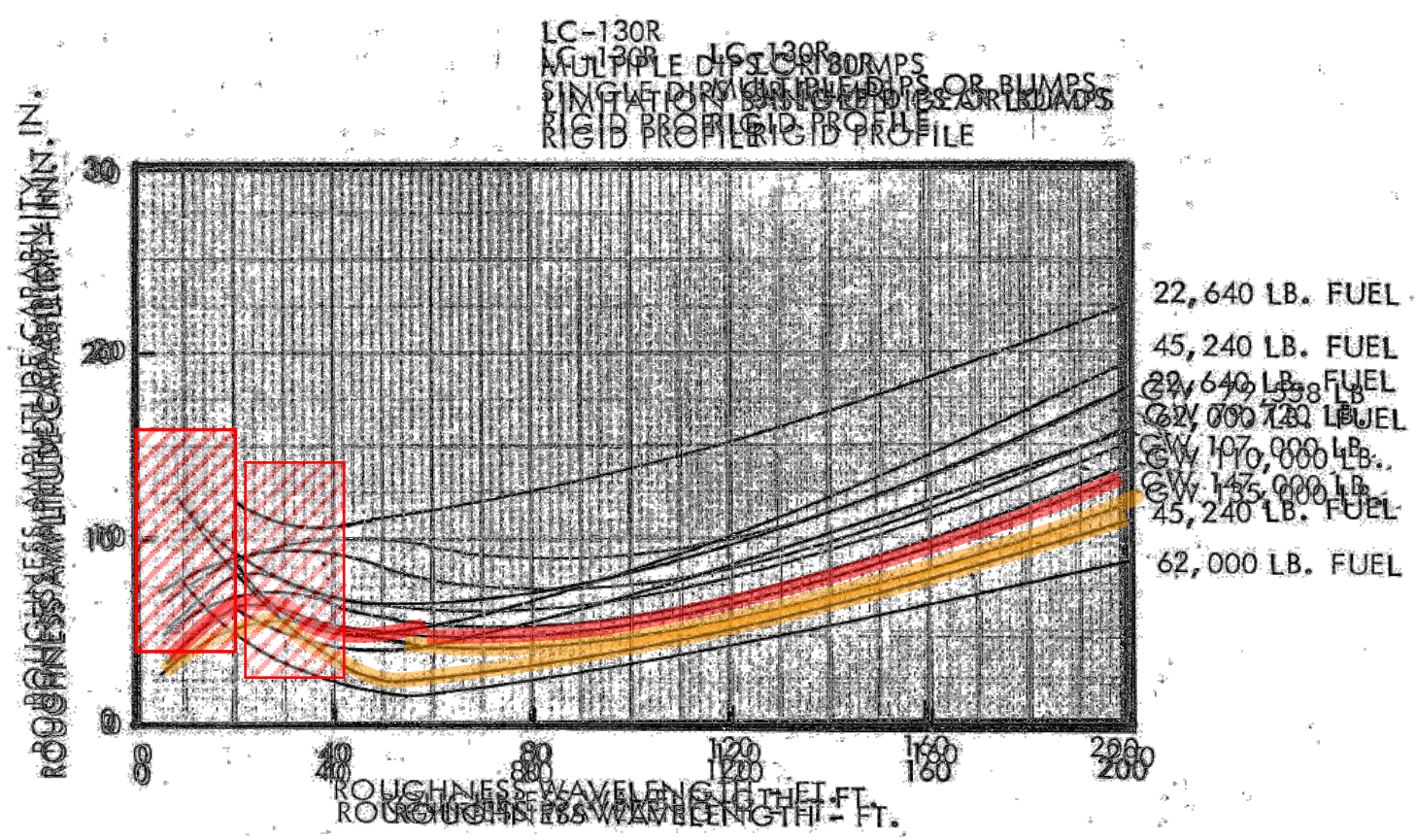

Two lines are highlighted. The yellow line represents the worst-case line for multiple bumps; and the red for single bumps. The red box represents the LC-130 Flight Manual restriction 4"-in-20' restriction for gross weights at or above $135,000 l b s$. It must be noted that the bump amplitudes assume a hard surface with zero deformation; and bump length is the full distance end to end as shown in Figure B10.

Figure B10. Depiction of roughness amplitude and wavelength.

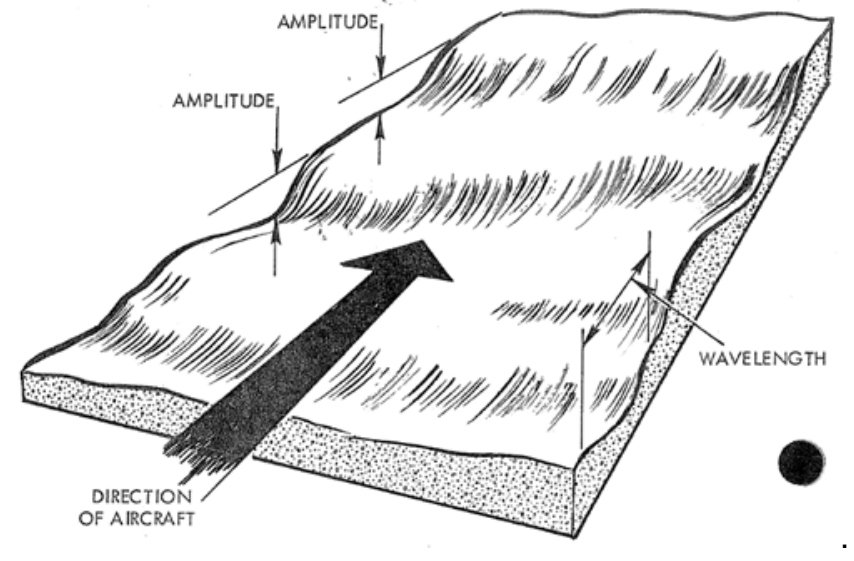


At this point, it is useful to compare the Lockheed criteria against the other criteria mentioned earlier. Figure B3 is a composite chart depicting the criteria of the LC-130 Flight Manual, MIL-A-8862, ML-A-8863 and the Lockheed report. It shows that the different criteria are in line with one another; particularly the Semi-Prepared Airfield of MIL-A-8863 with the Lockheed limit for 135,000lbs and 45,000lbs of fuel. The small difference can be explained by recalling that the Lockheed criterion assumes a rigid surface with zero deformation, and MIL-A-8863 semi-prepared airfields have a CBR as low as 10; and the Lockheed report accounts for LC-130 resonances whereas MIL-A-8863 is generic.

The experienced ski pilot may think that the criteria are too stringent. LC130s occasionally operate over rougher snow and yet none have experience catastrophic failure aside from occasional ski or gear damage; and the rare occasions of damage have been later found to have a material defect as the root cause. In practice, there are likely a couple of mitigating factors that lessen the potential for damage. First, the snow surface is rarely rigid. In nearly all cases, the ski deforms the snow and effectively flattens the bumps. Thus, snow hardness must be considered when evaluating the roughness at a potential landing site. The author's personal experience with wheel operations on rigid-surface blue-ice sites bolsters the necessity for airfield with limited roughness. In particular, Odell Glacier with a combination of short-wave (approximately 6-12 inch) bumps overlying longwave ( $\sim 50-200$ foot) undulations. While the short-wave bumps induced a harsh chatter, it was the long-wave undulations that ultimately caused the most stress. Unfortunately the actual roughness was never measured. The second mitigating factor is that the Lockheed criteria places the boundary at the aircraft "limit" load - the highest load expected in service when the aircraft was designed. Whereas, structural failure will not occur until the load exceeds the "ultimate" load which is typically $150 \%$ of the "limit" load. Accordingly, there is a risk any time a LC-130 operates on a rough surface which exceeds the limit load. The limit load is unknown to the pilot; and the long-term effects to the airframe are unknown.

With this set of information, we now arrive at the point of determining the allowable roughness criteria for operations between 125,000 and 135,000 lbs. The recommended criterion represents an aggregate solution of the sources cited above; with the heaviest consideration awarded to the Lockheed report. The recommended roughness level closely follows the Lockheed criteria between single and multiple bumps for a 135,000lb aircraft. 
See the red line on Figure B11. The line begins at the Flight Manual restriction of 4 inches over a 20 -foot length (40-foot wavelength), and continues between the Lockheed criteria for single and multiple bumps.

Again, this represents the limit for a rigid surface. Since it is expected that the surface will be snow-covered and not quite rigid, some allowance can be afforded for seemingly rougher conditions. This will be accounted for by estimating the deformation and final bump amplitude after passage of a ski under 5-7 psi load.

\section{Conclusion}

Future opportunities for new LC-130 sites across Antarctica are certain; and this practical guidance not only allows operations on new sites with initial landing weights above the customary open-snow limits, but also gives the skiway construction teams and aircrew descriptions of necessary information required for successful operations. LC-130s have safely operated on rough surfaces for decades with little difficulty. Although it is acknowledged that the stress on the LC-130 is greater than most other C130 s, the risk is accepted as a requirement of the mission. Much of the success is due to the judgment of experienced aircrew. This expertise is a product of knowledge passed on to successive generations of aircrew, bolstered by contemporary experiences in Greenland and Antarctica. The objective of this paper is not to restrict, or limit, future operations. It is quite the opposite, in the sense it will allow the LC-130 to expand its radius of operations by allowing gross weights to permit ample cargo loads while carrying the necessary fuel to new sites where on-site SLACO visits may not be practicable. As we look ahead to the future, it is expected that this paper will serve as the basis for continued analysis that will be incorporated into aircrew training and skiway construction 
Figure B11. Recommended roughness capability for Casey Station for LC-130 operations.

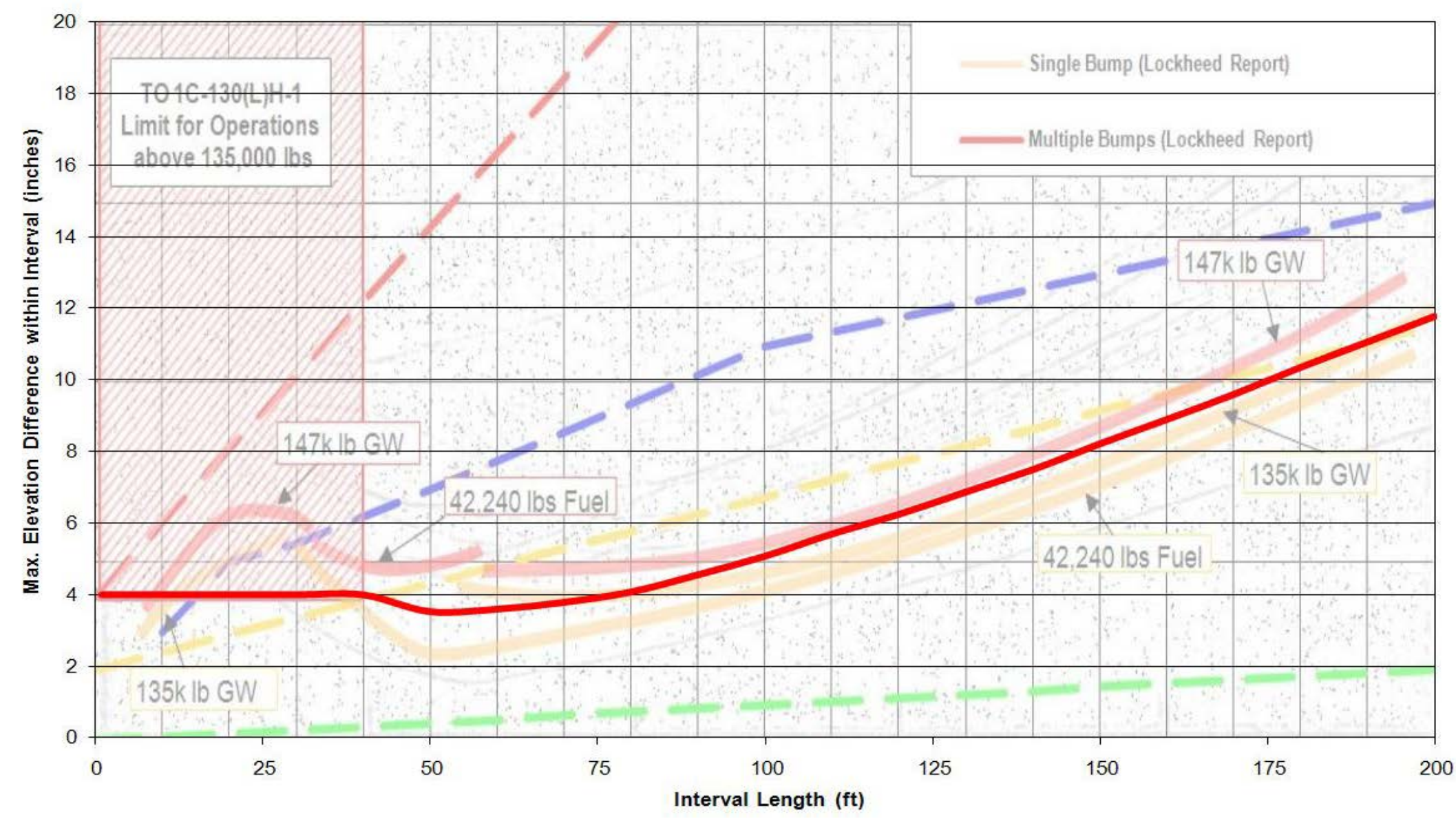




\section{References}

AFI 11-2C-130V3, C-130 Operations Procedures, 14 March 2006.

AFI 13-217, Drop Zone and Landing Zone Operations, 10 May 2007.

AFI 32-1041, Airfield Pavement Evaluation Program, 25 April 1994.

Air Force Pamphlet (AFPAM) 10-219 V4, Airfield Damage Repair Operations, 28 May 2008.

Boeing Commercial Airplane Group report D6-81746, Runway Roughness Measurement, Quantification, and Application - The Boeing Method, 2002.

FAA AC 150/5380-9, Guidelines and Procedures for Measuring Airfield Pavement Roughness, 30 September 2009.

FM 5-430-00-2/AFJ PAM32-8013 V2, Planning and Design of Roads, Airfields, and Heliports in the Theater of Operations - Airfield and Heliport Design, 29 Sept 1994.

Lockheed Report LG77ER0005, Establishment of Roughness Criteria for LC-130 Antarctic Operations, January 1977.

MIL-A-8862, Airplane Strength and Rigidity Landplane Landing and Ground Loads, 18 May, 1960.

MIL-A-8863C Airplane Strength and Rigidity Ground Loads for Navy-Acquired Airplanes, 19 J uly, 1993.

NASA Memorandum 2-21-59L, Study of Taxiing Problems Associated with Runway Roughness, March 1959

T.O. 1C-130(L)H-1, Flight Manual, 26 J uly 2004.

T.O. 35E2-4-1, Repair Quality Criteria (RQC).

UFC 3-130-3, Runway and Road Design: Arctic and Subarctic Construction, 16 J anuary 2004.

UFC 3-260-1, Airfield and Heliport Planning and Design, 17 November 2008.

UFC 3-260-2, Airfield Pavement Design for Airfields, 30 J une 2001.

UFC 3-260-3, Airfield Pavement Evaluation, 15 April 2001.

UFC 3-260-16FA, Airfield Pavement Condition Survey Procedures, 16 J anuary 2004.

UFC 3-270-07, Airfield Damage Repair, 12, August 2002. 


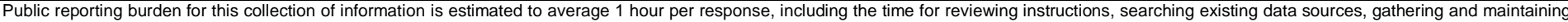

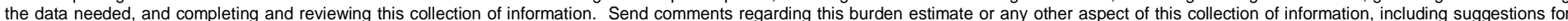

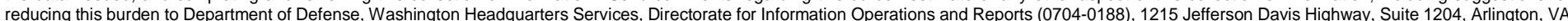

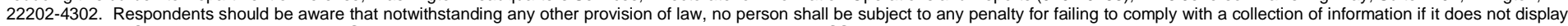
a currently valid OMB control number. PLEASE DO NOT RETURN YOUR FORM TO THE ABOVE ADDRESS.
1. REPORT DATE (DD-MM-YYYY)
2. REPORT TYPE
May 2017
Special Report/Final

3. DATES COVERED (From - To)

\section{TITLE AND SUBTITLE}

Landing-Zone and Drop-Zone Criteria

5a. CONTRACT NUMBER

5b. GRANT NUMBER

5c. PROGRAM ELEMENT NUMBER

\section{AUTHOR(S)}

Wendy L. Wieder and Sally A. Shoop

\section{5d. PROJECT NUMBER}

5e. TASK NUMBER

5f. WORK UNIT NUMBER

9K3D08

\section{PERFORMING ORGANIZATION NAME(S) AND ADDRESS(ES)}

8. PERFORMING ORGANIZATION REPORT
NUMBER

U.S. Army Engineer Research and Development Center (ERDC)

Cold Regions Research and Engineering Laboratory (CRREL)

ERDC/CRREL SR-17-1

72 Lyme Road

Hanover, NH 03755-1290

\section{SPONSORING I MONITORING AGENCY NAME(S) AND ADDRESS(ES)}

Army Terrestrial Environmental Modeling and Intelligence System (ARTEMIS)

U.S. Army Engineer Research and Development Center (ERDC)

Cold Regions Research and Engineering Laboratory (CRREL)

ERDC/CRREL SR-17-1

72 Lyme Road

Hanover, NH 03755-1290

12. DISTRIBUTION I AVAILABILITY STATEMENT

Approved for public release; distribution is unlimited.

\section{SUPPLEMENTARY NOTES}

Geospatial Remote Assessment for Ingress Locations (GRAIL)

\section{ABSTRACT}

The criteria for landing zones (LZs) and drop zones (DZs), also known as austere entry surfaces, are extensive and varied. They range from very specific guidance on required geometry to more general guidance on required bearing strength of unprepared surfaces, such as soil or ice, and the smoothness of those surfaces. Current practice for siting LZs and DZs includes site surveys by trained personnel, often in hostile environments. Additionally, with the continued advancement of image analysis, it may be possible to identify potential LZ and DZ sites remotely and thus to reduce the need to expose personnel to dangerous conditions. This review intends to summarize existing Federal, Department of Defense, and other criteria for unsurfaced, unimproved LZs and DZs. The purpose of the summary is to consolidate criteria so that the criteria may be considered in the process of developing and refining methods to remotely locate and assess potential LZs and DZs by using satellite imagery.

\section{SUBJECT TERMS}

Airborne operations (Military science), Airfields, Airmobile operations (Military science), Austere, Guidance, Image analysis, Remote, Remote-sensing images, Unimproved, Unsurfaced

\section{SECURITY CLASSIFICATION OF:}

\section{a. REPORT}

Unclassified

\section{b. ABSTRACT}

Unclassified

\section{c. THIS PAGE}

Unclassified

\begin{tabular}{c|c|} 
17. LIMITATION & $\begin{array}{c}\text { 18. NUMBER } \\
\text { OF ABSTRACT }\end{array}$ \\
OF PAGES \\
SAR & 148
\end{tabular}

19a. NAME OF RESPONSIBLE PERSON

19b. TELEPHONE NUMBER (include area code) 